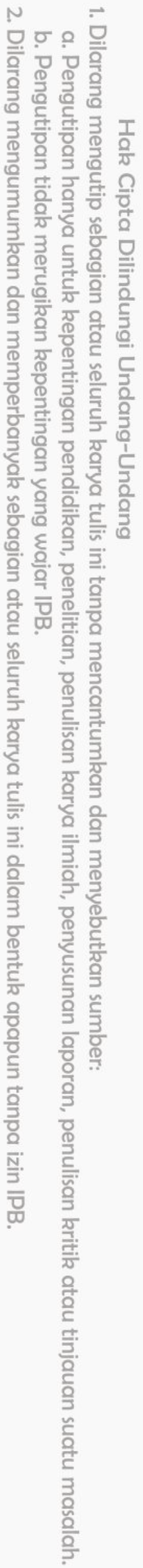

EVALUASI KENYAMANAN TERMAL DAN KUALITAS

ESTETIKA PADA BEBERAPA TAMAN KOTA BANDA ACEH

AZWINUR

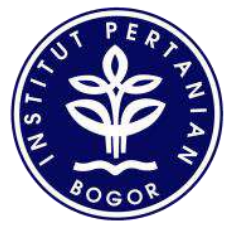

DEPARTEMEN ARSITEKTUR LANSKAP

FAKULTAS PERTANIAN

INSTITUT PERTANIAN BOGOR

BOGOR

2016 
모 웅

흠마을

을 흐을

可言言

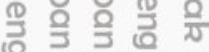

도의

3응을 훙 훙

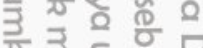

을 옥 올 을.

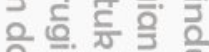

일 정의

了ํㅗㄱ융 을 은

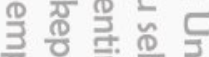

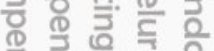

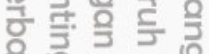

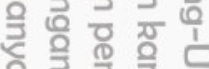

원드을 을

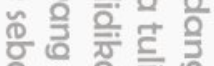

ह

을. 응. 흥

윽 웅

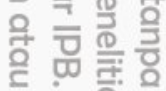

(O)

节

둥

于 豆刍

을 을

일 일

들 을 을

을 글

응 혹 일

每 कृ

익 롱

空 突

응 을

응 응 항

읭

일

흥

촠. 를

ㅁํㅁ

咨

으미

웅

豈

ใ

은

흘

10

킁

을 


\section{PERNYATAAN MENGENAI SKRIPSI DAN SUMBER INFORMASI SERTA PELIMPAHAN HAK CIPTA}

Dengan ini saya menyatakan bahwa skripsi berjudul Evaluasi Kenyamanan Termal dan Kualitas Estetika pada Beberapa Taman Kota Banda Aceh adalah benar karya saya dengan arahan dari komisi pembimbing dan belum diajukan dalam bentuk apa pun kepada perguruan tinggi mana pun. Sumber informasi yang berasal atau dikutip dari karya yang diterbitkan maupun tidak diterbitkan dari penulis lain telah disebutkan dalam teks dan dicantumkan dalam Daftar Pustaka di bagian akhir skripsi ini.

Dengan ini saya melimpahkan hak cipta dari karya tulis saya kepada Institut Pertanian Bogor.

Bogor, Maret 2016

Azwinur NIM A44110076 


\section{ABSTRAK}

AZWINUR. Evaluasi Kenyamanan Termal dan Kualitas Estetika pada Beberapa Taman Kota Banda Aceh. Dibimbing oleh TATI BUDIARTI

Penelitian ini berfokus pada tiga taman kota di Kota Banda Aceh, yakni Taman Putroe Phang, Lapangan Blang Padang, dan Hutan Kota BNI. Penelitian ini bertujuan untuk mengidentifikasi karakteristik kondisi taman kota eksisting, menganalisis tingkat kenyamanan termal dan kualitas estetika, serta menyusun rekomendasi terhadap perbaikan taman kota pada waktu yang akan datang. Metode penelitian menggunakan metode deskriptif melalui perhitungan Thermal Humidity Index (THI), Scenic Beauty Estimation (SBE), serta kuesioner terhadap persepsi dan preferensi pengunjung. Berdasarkan hasil perhitungan THI, tingkat kenyamanan termal pada lokasi penelitian termasuk dalam kategori cukup nyaman. Bagian taman yang menghasilkan tingkat kenyamanan termal paling baik adalah area taman yang mempunyai vegetasi dominan berupa pohon. Berdasarkan hasil evaluasi kualitas estetika, terdapat faktor yang memengaruhi kualitas estetika pada ketiga lokasi penelitian, yaitu kerapihan; kombinasi elemen lanskap yang terdiri atas vegetasi, air, dan perkerasan; serta penataan lanskap yang melibatkan prinsipprinsip desain. Berdasarkan kuesioner terhadap pengunjung, diketahui bahwa pengunjung menginginkan adanya penambahan fasilitas untuk menunjang aktivitas, serta penambahan penggünaan tanaman berbunga dan tanaman peneduh untuk meningkatkan keindahan dan kenyamanan taman kota.

Kata kunci: evaluasi lanskap, kualitas estetika, taman kota, tingkat kenyamanan termal

\section{ABSTRACT}

AZWINUR. The Thermal Comfort Index and Aesthetic Quality Evaluation of Several Parks in Banda Aceh City. Supervised by TATI BUDIARTI

This research focuses on three city parks in Banda Aceh City, that are Taman Putroe Phang, Lapangan Blang Padang, and Hutan Kota BNI. The purposes of this research are to identify the characteristic of city parks existing condition, to analyze the thermal comfort index and aesthetic quality, as well as to suggest the recommendation of city parks improvement for the future. The method on this research using descriptive method through the calculation of Thermal Humidity Index (THI), Scenic Beauty Estimation (SBE), and questionnaires to the perceptions and preferences of visitors. Based on THI calculation, thermal comfort index on research sites classified in the category of quite comfortable. The part of city parks that represent the best of thermal comfort index is the area which has trees as the dominant vegetation. Based on the aesthetic quality evaluation, there are several factors that affect the aesthetic quality of the three research locations, that are the neatness; the combination of landscape element which consist of vegetation, water, and also pavement; as well as the arrangement of landscape that involves the principle of design. Based on visitor questionnaires, it is known that the visitors want some additional facilities to support their activities, and increasing the uses of flowering plants as well as shade plants to enhance the aesthetic quality and convenience of city parks.

Keywords: aesthetic quality, city parks, landscape evaluation, thermal comfort index 


\title{
EVALUASI KENYAMANAN TERMAL DAN KUALITAS ESTETIKA PADA BEBERAPA TAMAN KOTA BANDA ACEH
}

\section{AZWINUR}

\author{
Skripsi \\ sebagai salah satu syarat untuk memperoleh gelar \\ Sarjana Arsitektur Lanskap \\ pada \\ Departemen Arsitektur Lanskap
}

\author{
DEPARTEMEN ARSITEKTUR LANSKAP \\ FAKULTAS PERTANIAN \\ INSTITUT PERTANIAN BOGOR \\ BOGOR \\ 2016
}


모 웅

흠마을

을 흐을

可言言

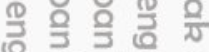

도의

3응을 훙 훙

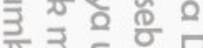

을 옥 올 을.

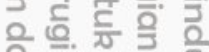

일 정의

了ํㅗㄱ융 을 은

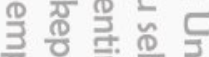

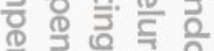

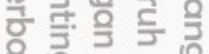

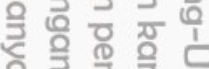

원드을 을

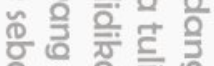

ह

을. 응. 흥

윽 웅

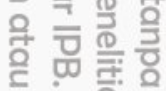

(O)

节

둥

于 豆刍

을 을

일 일

들 을 을

을 글

응 혹 일

每 कृ

익 롱

空 突

응 을

응 응 항

읭

일

흥

촠. 를

ㅁํㅁ

咨

으미

웅

豈

ใ

은

흘

10

킁

을 
Judul Skripsi: Evaluasi Kenyamanan Termal dan Kualitas Estetika pada Beberapa Taman Kota Banda Aceh

Nama : Azwinur

NIM : A44110076

Disetujui oleh
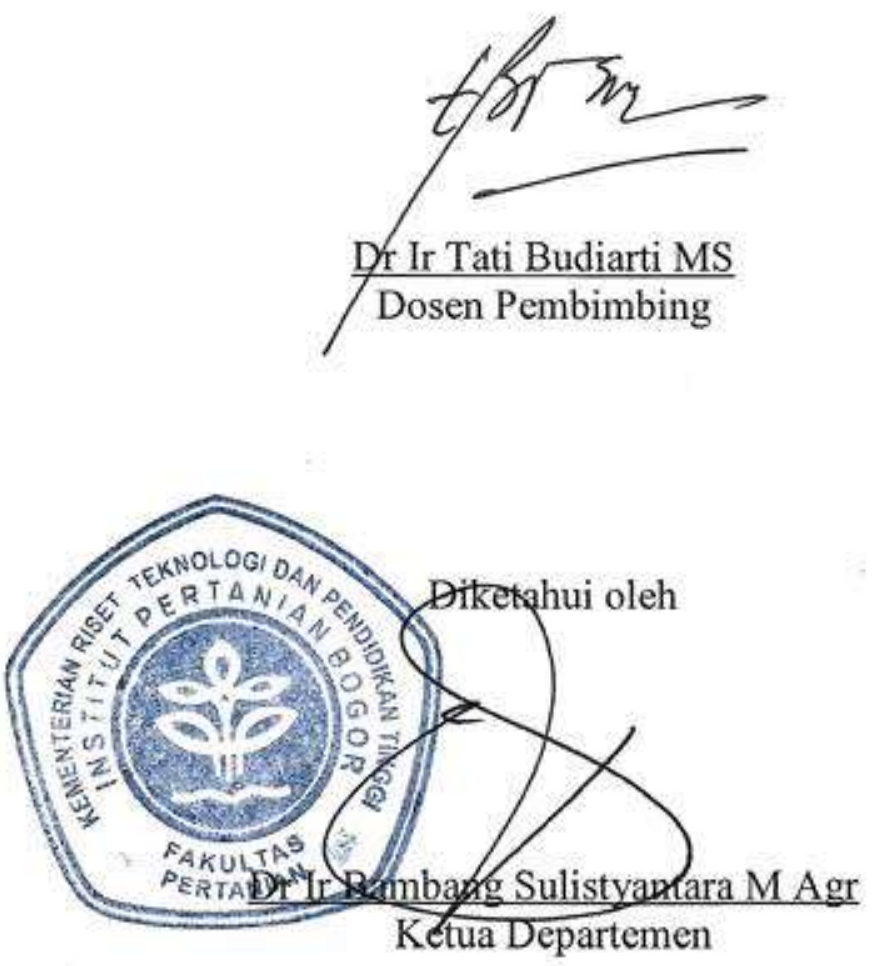

Tanggal Lulus: 18 MAY 2016 


\section{PRAKATA}

Puji syukur kehadirat Allah SWT atas limpahan rahmat dan karunia-Nya sehingga penulis mampu menyelesaikan skripsi berjudul "Evaluasi Kenyamanan Termal dan Kualitas Estetika pada Beberapa Taman Kota Banda Aceh". Skripsi ini disusun sebagai salah satu syarat untuk menyelesaikan program sarjana pada program studi Arsitektur Lanskap, Fakultas Pertanian, Institut Pertanian Bogor.

Penulis mengucapkan terima kasih kepada Dr Ir Tati Budiarti MS selaku dosen pembimbing skripsi atas masukan, saran, dan kritik yang sangat bermanfaat dalam penyusunan skripsi ini. Terima kasih kepada Bapak Dr Ir Nizar Nasrullah MAgr dan Ibu Prita Indah Pratiwi SP MAgrSc selaku dosen penguji skripsi atas segala saran, kritik, dan masukan yang membangun. Ungkapan terima kasih juga disampaikan kepada Bapak Akhmad Arifin Hadi SP MALA sebagai dosen pembimbing akademik atas bimbingan dan pembelajaran yang diberikan, kepada keduả orang tua yang selalu memberikan doa dan dukungan untuk penyelesaian skripsii ini, kepada Suci Novilani yang selalu memberikan semangat, kepada temanteman: Arsitektur Lanskap angkatan 48 dan 49 yang sudah bersedia menjadi respoñden dalam penelitian, kepada Sholihin Nafar yang sudah membantu dalam menyelesaikan skripsi ini. Terima kasih kepada penghuni Asrama Mahasiswa Aceh Leuser, serta semua pihak yang telah mendukung dan membantu dalam penyusunan skripsì ini.

Penulis sangat menyadari bahwa skripsi ini belum sempurna. Oleh karena itu, penulis mengharapkan kritik dan saran yang membangun untuk kelancaran pelaksanaan penelitian yang akan dilakukan.

Bogor, Maret 2016 


\section{DAFTAR ISI}

PRAKATA vi

DAFTAR TABEL $\quad$ ix

DAFTAR GAMBAR $\quad$ ix

DAFTAR LAMPIRAN $\quad$ xi

PENDAHULUAN 1

Latar Belakang 1

Tujuan Penelitian 2

Manfaat Penelitian 2

Kerangka Pikir 2

TIÑJAUAN PUSTAKA

Eỹaluasi 4

Rüang Terbuka Hijau Kota 4

Tâman Kota 6

Iklim Mikro $\quad 7$

Hubungan RTH dengan Kenyamanan Manusia $\quad 7$

Témperature Humidity Index (THI) 8

Estetika Lanskap $\quad 8$

METODE 9

Lokasi dan Waktu Penelitian 9

$\begin{array}{ll}\text { Alat dan Bahan } & 10\end{array}$

$\begin{array}{ll}\text { Metode Penelitian } & 10\end{array}$

$\begin{array}{ll}\text { KONDISI UMUM } & 19\end{array}$

Letak, Luas, dan Batas Lokasi 19

$\begin{array}{ll}\text { Sejarah } & 20\end{array}$

$\begin{array}{ll}\text { Kondisi Fisik } & 23\end{array}$

HASIL DAN PEMBAHASAN 27

Sebaran Ruang Terbuka Hijau Kota Banda Aceh $\quad 27$

Indentifikasi Jenis dan Fungsi Tanaman 28

Evaluasi Kenyamanan Termal 33

Evaluasi Kualitas Estetika Lanskap 43

Persepsi dan Preferensi Pengunjung 58 


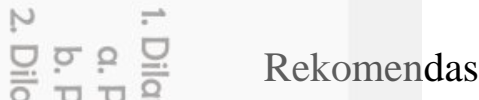

SIMPULAN DAN SARAN

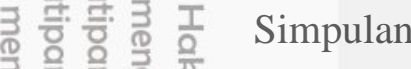

Saran 67

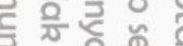

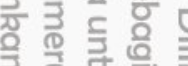

LAMPIRAN

DAFTAR PUSTAKA

要

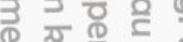

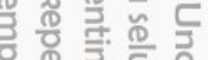

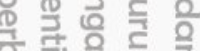

응

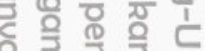

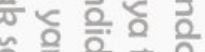

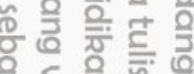

ह 을

응응

要

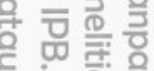

일

列

일

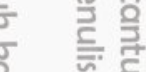

号表

직 익

돌 응

ㄹ. 을

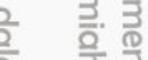

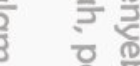

일

응 을

응 응 항

잉 


\section{DAFTAR TABEL}

1. Alat yang digunakan dalam penelitian 10

2. Jenis dan sumber data yang digunakan 11

3. Lokasi area pengukuran suhu dan kelembapan di Taman Putroe Phang 13

4. Lokasi pengukuran suhu dan kelembapan di Lapangan Blang Padang 14

5. Lokasi pengukuran suhu dan kelembapan di Hutan Kota BNI 15

6. Bentuk dan luasan RTH Kota Banda Aceh 27

7. Sebaran vegetasi di tiga lokasi penelitian 28

8. Jenis dan fungsi vegetasi pada Taman Putroe Phang 28

9. Jenis dan fungsi vegetasi pada Lapangan Blang Padang 30

10. Jenis dan fungsi vegetasi pada Hutan Kota BNI 31

11. Rata-rata suhu udara tiga lokasi $\quad 35$

12. Keadaan iklim rata-rata wilayah Banda Aceh 36

13. Suhu rata-rata pada berbagai area ukur 37

14. Suhu rata-rata pada berbagai waktu ukur 37

15. Interaksi suhu antara waktu dan area ukur di Hutan Kota BNI 37

16. Kata-rata kelembapan udara tiga lokasi penelitian 39

17. Kelembapan rata-rata pada berbagai area ukur 40

18. Kelembapan rata-rata pada berbagai waktu ukur 40

19. Rata-rata nilai THI 42

20. Persentase kualitas estetika 44

21. Kategori kualitas estetika lanskap Taman Kota Putroe Phang 45

22. Kategori kualitas estetika lanskap Lapangan Blang Padang 50

23. Kategori kualitas estetika lanskap Hutan Kota BNI 54

\section{DAFTAR GAMBAR}

1. Kerangka pikir penelitian

2. Peta kondisi eksisting RTH Kota Banda Aceh 2009

3. Lokasi penelitian: (a) Hutan Kota BNI, (b) Lapangan Blang Padang, dan (c) Taman Putroe Phang

4. Diagram proses penelitian

5. Sistem pengukuran suhu dan kelembapan

6. Area pengukuran suhu dan kelembapan di Taman Putroe Phang

7. Area pengukuran suhu dan kelembapan di Lapangan Blang Padang

8. Area pengukuran suhu dan kelembapan di Hutan Kota BNI

9. Peta pembagian zona fisik Kota Banda Aceh

10. Renovasi setelah tsunami kerja sama Pemkot dan CIDA (kiri), tercatat sebagai Benda Cagar Budaya (tengah), Pinto Khop pada masa penjajahan Belanda (kanan)

11.Foto citra google earth, (kiri) sebelum dibangun tahun 2002, (tengah) ketika proses penimbunan tahun 2009, dan (kanan) sesudah dibangun tahun 2014

12. Kondisi fisik T. Putroe Phang: (a) papan informasi, (b) pinto khop, (c) pintu masuk, dan (d) area playground 
13. Kondisi fisik Lapangan Blang Padang: (a) gerbang masuk, (b) jogging track, (c) monumen Pesawat RI-01, dan (d) monumen terima kasih dan damai dari 53 negara

14. Kondisi fisik Hutan Kota BNI Tibang: (a) pembibitan pohon, (b) mushola, (c) sumur untuk penyiraman, dan (d) gerbang masuk

15. Kondisi eksisting RTH (a) kuburan masal tsunami (b) taman edukasi tsunami (c) simpadan Krueng Aceh (d) jalur hijau Pendopo Gubernur

16. Suhu udara rata-rata di tiga lokasi penelitian

17. Kelembapan rata-rata di tiga lokasi penelitian

18. Kategori nyaman berdasarkan metode THI dengan kombinasi nilai suhu udara dan kelembapan relatif yang berbeda

19. Indeks kenyamanan tiga lokasi penelitian pada pagi hari (a); siang hari (b); sore hari (c); dan harian (d)

20. Grafik-nilai SBE Taman Putroe Phang

21. Lanskap L dengan nilai SBE tertinggi (kiri), Lanskap AB dengan nilai SBE terendah (kanan)

22. Peta sebaran kualitas estetika Taman Putroe Phang

23. Grafikinilai SBE Lapangan Blang Padang

24. Lanskâp K dengan nilai SBE tertinggi (kiri), Lanskap V dengan nilai SBE terendah (kanan)

25. Peta sebaran kualitas estetika Lapangan Blang Padang

26. Grafik nilai SBE Hutan Kota BNI

27. Lanskap V dengan nilai SBE tertinggi (kiri), Lanskap B dengan nilai SBE terenđạh (kanan)

28. Peta sebaran kualitas estetika Hutan Kota BNI

29. Grafik persentase jenis kelamin responden di Taman Putroe Phang, Lapangan Blang Padang, dan Hutan Kota BNI

30. Grafik persentase profesi responden di Taman Putroe Phang, Lapangan BlangPadang, dan Hutan Kota BNI

31. Grafik persentase umur responden di Taman Putroe Phang, Lapangan BlangPadang, dan Hutan Kota BNI

32. Grafik persentase tujuan responden di Taman Putroe Phang, Lapangan Blang Padang, dan Hutan Kota BNI

33. Grafik jarak tempat tinggal responden terhadap Taman Putroe Phang, Lapangan Blang Padang, dan Hutan Kota BNI

34. Grafik persepsi responden terhadap penataan di Taman Putroe Phang, Lapangan Blang Padang, dan Hutan Kota BNI

35. Grafik lamanya kunjungan responden di Taman Putroe Phang, Lapangan Blang Padang, dan Hutan Kota BNI

36. Grafik persepsi responden terhadap kebersihan di Taman Putroe Phang, Lapangan Blang Padang, dan Hutan Kota BNI

37. Grafik persepsi responden terhadap kelembapan di Taman Putroe Phang, Lapangan Blang Padang, dan Hutan Kota BNI

38. Grafik persepsi responden terhadap suhu di Taman Putroe Phang, Lapangan Blang Padang, dan Hutan Kota BNI

39. Grafik persepsi responden terhadap estetika di Taman Putroe Phang, Lapangan Blang Padang, dan Hutan Kota BNI 
40. Grafik persentase preferensi responden mengenai aktivitas dan fasilitas di Taman Putroe Phang

41. Grafik persentase preferensi responden mengenai aktivitas dan fasilitas di Lapangan Blang Padang

42. Grafik persentase preferensi responden mengenai aktivitas dan fasilitas di Hutan Kota BNI

43. Contoh penerapan rekomendasi pada Taman Putro Phang, (kiri) kondisi eksisting, (kanan) hasil rekomendasi

44. Contoh penerapan rekomendasi pada Lapangan Blang Padang, (kiri) kondisi eksisting, (kanan) hasil rekomendasi

45. Contoh penerapan rekomendasi pada Hutan Kota BNI, (kiri) kondisi eksisting, (kanan) hasil rekomendasi

\section{DAFTAR LAMPIRAN}

1. Kuesioner Penelitian

2. Kuesioner penilaian estetika 73

3. Hasil Anova dan uji beda Suhu Taman Putroe Phang 74

4. Hasil Anova dan uji beda Suhu Lapangan Blang Padang 74

5. Hasil Anova dan uji beda Suhu Hutan Kota BNI 75

6. Hasil Anova dan uji beda Suhu Ketiga lokasi 76

7. Hasil Anova dan uji beda kelembaban Taman Putroe Phang 77

8. Hasil Anova dan uji beda kelembaban Lapangan Blang Padang 78

9. Hasil Anova dan uji beda kelembaban Hutan Kota BNI 79

10. Hasil Anova dan uji beda kelembaban ketiga lokasi 79 
모 웅

흠마을

을 흐을

可言言

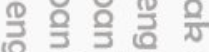

도의

3응을 훙 훙

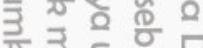

을 옥 올 을.

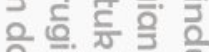

일 정의

了ํㅗㄱ융 을 은

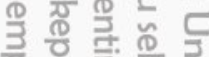

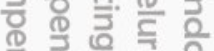

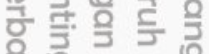

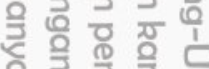

원드을 을

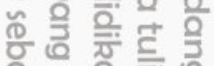

ह

을. 응. 흥

윽 웅

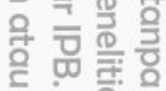

(O)

节

둥

于 豆刍

을 을

일 일

들 을 을

을 글

응 혹 일

每 कृ

익 롱

空 突

응 을

응 응 항

읭

일

흥

촠. 를

ㅁํㅁ

咨

으미

웅

豈

ใ

은

흘

10

킁

을 


\section{PENDAHULUAN}

\section{Latar Belakang}

Pembangunan infrastruktur Kota Banda Aceh setelah bencana tsunami tahun 2004 terus bertambah. Alih fungsi lahan menjadi area terbangun terus meningkat. Area terbangun yang terus bertambah dapat menyebabkan penurunan kualitas lingkungan seperti pencemaran air, peningkatan suhu udara, perubahan iklim, dan berkurangnya keanekaragaman hayati. Maharani (2015) mengatakan bahwa berdasarkan data dari BMKG tahun 2015, Kota Banda Aceh termasuk ke dalam kotaterpanas di Indonesia yaitu mencapai suhu $36.4{ }^{\circ} \mathrm{C}$.

- Salah satu cara mengatasi masalah lingkungan yang dilakukan oleh pemerintah Kota Banda Aceh adalah dengan membangun Ruang terbuka hijau (RTH). Banda Aceh saat ini memiliki RTH dengan luas $668.9 \mathrm{Ha}$ atau $12 \%$ dari total wilayahnya. Pemkot dan beberapa dinas terkait terus berupaya menambah kualitas RTH tersebut lewat program-program seperti Program Pengembangan Kota Hijau (P2KH), membangun jalur-jalur sepeda, penanaman mangrove pada kawasan perlindungan di garis pantai untuk mencegah bencana tsunami, hingga penāmbahan hutan dan taman kota. QANUN RTRW Kota Banda Aceh NO. 4 Tahun 2009 menyatakan bahwa ruang terbuka hijau menjadi bagian dari kawasan lindung kota, kawasan ruang terbuka hijau tersebut harus mencapai jumlah minimal $30 \%$ dari luas total wilayahnya.

Ruang terbuka hijau (RTH) mempunyai manfaat dalam aspek ekologi, sosial, budàya, ekonomi, dan estetika. Ruang terbuka hijau (RTH) merupakan salah satu bagian utama dari pembangunan dan pengelolaan ruang-ruang kota dalam upaya men̈gendalikan kapasitas dan kualitas lingkungannya, serta dapat meningkatkan kesejahteraan masyarakat melalui sarana bermain dan rekreasi. Menurut Joga dan Ismaun (2011), RTH mempunyai manfaat di antaranya yaitu, dapat menurunkan suhu udara sehingga dapat menciptakan lingkungan hidup perkotaan yang nyaman, sebaggai sarana lingkungan perkotaan, menciptakan keserasian lingkungan alami dan lingkungan binaan yang berguna untuk kepentingan masyarakat, serta menciptakan kota yang sehat, layak huni, dan berkelanjutan. Bentuk-bentuk RTH antara lain dapat berupa taman kota, jalur hijau jalan, hutan kota, area pemakaman, lapangan, dan badan air.

Taman kota merupakan ruang terbuka hijau kota yang pemanfaatannya tidak hanya sebagai pengendali lingkungan saja, tetapi sebagai wahana untuk rekreasi warga kota. Kota Banda Aceh sendiri memiliki taman kota yang minat pengunjungnya sangat minim dibandingkan dengan tempat-tempat rekreasi lainnya seperti rekreasi tepi pantai, kota tua, masjid raya, dan wisata mengenang bencana tsunami.

Taman kota yang baik adalah taman yang mampu menyediakan jasa lingkungan demi keberlangsungan hidup manusia. Banda Aceh memiliki RTH publik yang pemanfaatannya masih kurang untuk warga kota. RTH publik seharusnya dapat memberi kenyamanan dan kesejahteraan bagi masyarakat kota, baik secara jasmani maupun rohani. Oleh karena itu taman kota sebagai RTH publik harus memerhatikan dua aspek penting, yaitu aspek kenyamanan dan aspek estetika yang dapat mengatasi masalah lingkungan kota, dapat meningkatkan keindahan 
kota, dan mampu menarik para pengunjung untuk menikmati taman-taman kota tersebut. Hal di tersebut menjadi urgensi dilakukannya penelitian yang berjudul "Evaluasi Kenyamanan Termal dan Kualitas Estetika pada Beberapa Taman Kota - Banda Aceh". Evaluasi yang dilakukan menggunakan tingkat kenyamanan termal dan estetika pada tiga bentuk taman kota di Kota Banda Aceh. Hasil dari evaluasi tersebut yang berupa rekomendasi harapannya dapat digunakan untuk perbaikan taman-taman kota demi menciptakan kenyamanan termal dan estetika pada waktu yang akan datang.

\section{Tujuan Penelitian}

Penelitian ini dilakukan dengan tujuan sebagai berikut:

1. mengidentifikasi karakteristik berbagai bentuk taman kota eksisting di Kota Banda Aceh (Taman Putroe Phang, Lapangan Blang Padang, dan Hutan Kota $\mathrm{BN}($ ),

2. menganalisis tingkat kenyamanan termal dan menilai kualitas estetika pada beberapa taman, dan

3. menyusun rekomendasi untuk taman-taman kota tersebut.

\section{Manfaat Penelitian}

Hasil penelitian ini diharapkan dapat memberikan informasi dan rekomenđạsi tentang tingkat kenyamanan termal dan kualitas estetika beberapa taman kota di Kota Banda Aceh. Informasi persepsi dan preferensi masyarakat dan pengunjung terhadap taman kota. Sebagai bahan referensi untuk penelitian selanjutnyaa, serta sebagai masukan bagi Pemerintah Kota Banda Aceh (Dinas Kebersihān dan Keindahan) untuk perbaikan dan pengembangan ruang terbuka hijau ke arah yang lebih baik.

\section{Kerangka Pikir}

Kôta Banda Aceh saat ini membutuhkan ruang terbuka hijau (RTH) untuk menunjang kehidupan kota, salah satunya meningkatkan kenyamanan lingkungan dan estetika kota. Penelitian ini dilakukan pada beberapa bentuk (dihapus) taman kota yang tergolong ke dalam ruang terbuka hijau (RTH) publik yang terdapat di Kota Banda Aceh. Penilaian kenyamanan termal dilakukan dengan cara pengukuran suhu, kelembapan, dan persepsi pengunjung yang dilakukan pada lokasi penelitian. Pengukuran suhu dan kelembapan dilakukan pada beberapa bentuk penutupan lahan seperti area terbuka, area tutupan rumput, area di bawah naungan pohon, dan area pemukiman di luar taman. Penilaian kualitas estetika dilakukan menggunakan metode Scenic Beauty Estimation (SBE) dengan responden mahasiswa arsitektur lanskap semester 6 dan 8. Informasi mengenai persepsi dan preferensi pengunjung diperoleh melalui penyebaran kuesioner kepada pengunjung di setiap taman tersebut. Hasil dari penelitian ini berupa rekomendasi mengenai penataan RTH terutama pada taman-taman kota yang mampu memberikan manfaat lebih bagi masyarakat dan pemerintah Kota Banda Aceh. 


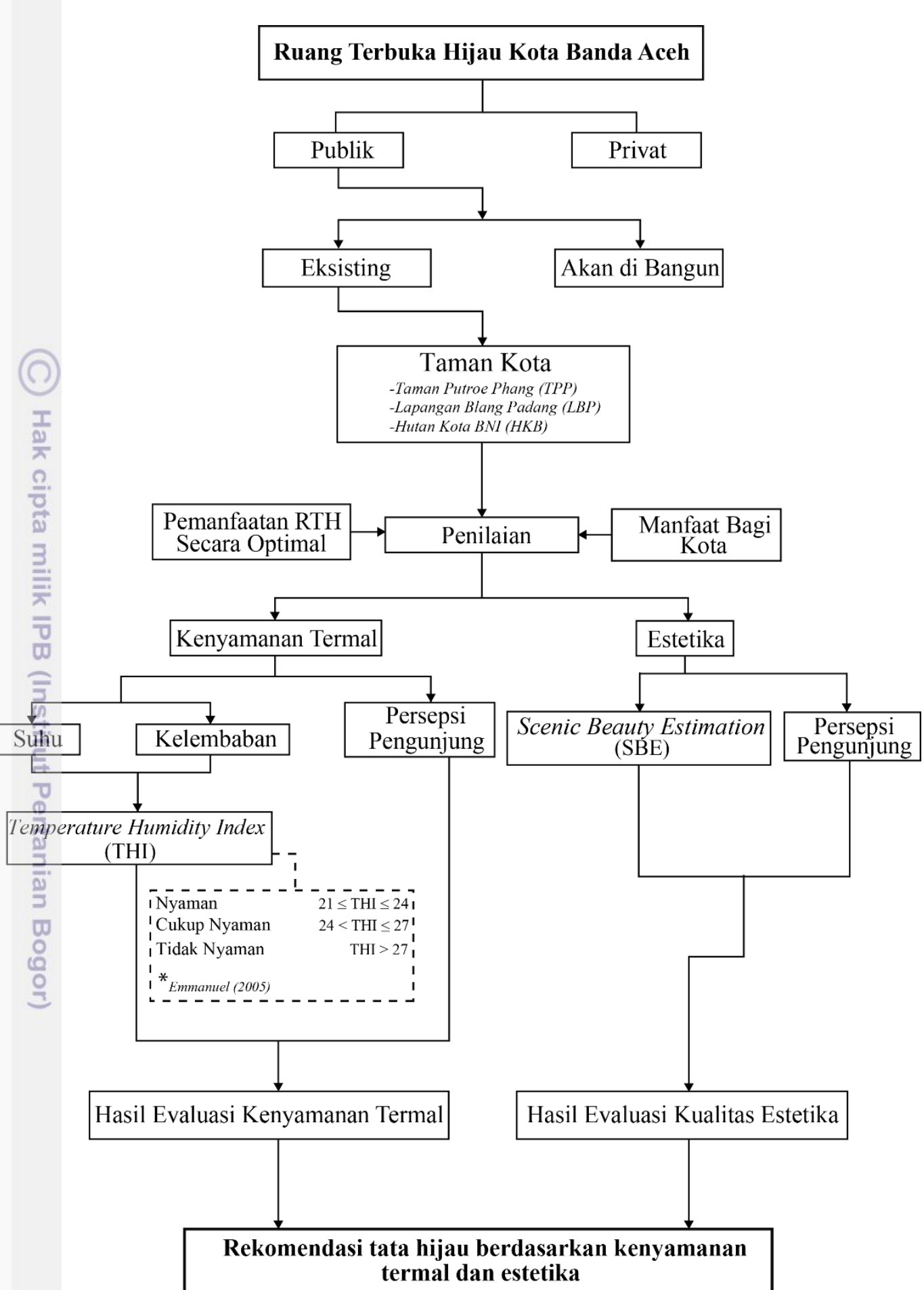

Gambar 1 Kerangka pikir penelitian 


\section{TINJAUAN PUSTAKA}

\section{Evaluasi}

Evaluasi merupakan proses menilai, membandingkan, dan memberi saran dalam hal perbaikan. Menurut Eliza dalam Vitasari (2004), kegiatan evaluasi bertujuan untuk menyeleksi dan menampilkan informasi yang diperlukan dalam mendukung pengambilan kesimpulan dan keputusan tentang suatu nilai serta nilainya. Evaluasi dilakukan dengan menggunakan pembanding yaitu perbandingan hasil perencanaan dengan tujuan yang ditetapkan oleh desainer. Evaluasi adalah suatu proses dalam merencanakan, memperoleh, dan menyediakan informasi yang sangat diperlukan untuk membuat alternatif keputusan. Evaluasi merupakan suatu tindakan yang dilakukan untuk menelaah atau menduga hal-hal yang sudah diputuskan untuk mengetahui kelemahan dan kelebihan keputusan tersebut. Selanjutnya ditentukan langkah-langkah alternatif perbaikannya bagi kelemahan tersebut. Tujuan evaluasi yaitu untuk membandingkan antara hasil implementasi dengan standar kriteria yang telah ditetapkan, kemudian dari evaluasi akan didapatkan nilai-nilai sejauh mana suatu program atau kegiatan telah berhasil dilakukan sehingga dapat diputuskan apakah program tersebut dapat dilanjutkan atau diganti dengan alternatif lain.

\section{Ruang Terbuka Hijau Kota}

Ruāng terbuka hijau adalah area memanjang baik berupa jalur maupun mengelompok yang penggunaanya bersifat terbuka, sebagai tempat tumbuhnya vegetasi-vegetasi, baik yang sudah tumbuh alami maupun yang sengaja ditanam (UU RI No. 26 Tahun 2007). Ruang terbuka hijau kota merupakan bagian dari penataan perkotaan yang berfungsi sebagai kawasan lindung atau konservasi. Ruang terbuka hijau diklasifikasikan berdasarkan status kawasan, bukan berdasarkan bentuk dan struktur vegetasinya (Fandeli 2009).

Berdasarkan UU No. 26 Tahun 2007 tentang Penataan Ruang, dinyatakan RTH memiliki proporsi 30\% dari luas wilayah kota. Tujuan pembentukan RTH di wilayah perkotaan menurut PermenPU No. 5 Tahun 2008 Pasal 3 dijelaskan, yaitu :

1. menjaga ketersediaan lahan sebagai kawasan resapan air

2. menciptakan aspek planologis perkotaan melalui keseimbangan antara lingkungan alam dan lingkungan binaan yang berguna untuk kepentingan masyarakat

3. meningkatkan keserasian lingkungan perkotaan sebagai sarana pengamanan lingkungan perkotaan yang aman, nyaman, segar, indah, dan bersih.

Komponen RTH berdasarkan kriteria, sasaran, fungsi penting, vegetasi, dan intensitas manajemennya dikategorikan dalam:

1. taman, fungsi utamanya adalah menghasilkan oksigen. Oleh karena itu jenis tanaman yang dibudidayakan dipilih dari jenis-jenis yang menghasilkan oksigen tinggi.

2. jalur hijau, termasuk di dalamnya adalah pepohononan peneduh pinggir jalan, jalur hijau lainnya. 
3. kebun dan pekarangan, selain bertujuan untuk produksi, kebun dan pekarangan hendaknya ditanam dengan jenis-jenis yang mendukung kenyamanan lingkungan.

4. hutan, merupakan penerapan beberapa fungsi hutan seperti ameliorasi iklim, hidrologi, dan penangkalan pencemaran. Fungsi-fungsi ini bertujuan mengimbangi kecenderungan menurunnya kualitas lingkungan.

5. tempat rekreasi, di samping jenisnya yang beragam, RTH memiliki manfaat yang besar bagi kelangsungan hidup manusia.

Beberapa pengertian RTH antara lain, ruang yang didominasi oleh lingkungan alami di luar maupun di dalam kota, baik berupa taman, halaman, area rekreasi kota dan jalur hijau. RTH merupakan salah satu bagian utama dari pembangunan dan pengelolaan ruang-ruang kota dalam upaya mengendalikan kapasitas dan kualitas lingkungannya dan pada saat yang bersamaan juga untuk meningkatkan kesejahteraan warganya. RTH publik adalah RTH yang dimiliki dan dikelola oleh pemerintah daerah kota/kabupaten yang digunakan untuk kepentingan masyarakat secara umum.

Proporsi RTH menurut undang-undang harus mencapai luas $30 \%$ dari luas wilayah kota. Proporsi tersebut terdiri atas $20 \%$ RTH publik dan $10 \%$ RTH privat. Proporsi $30 \%$ merupakan ukuran minimal untuk menjamin keseimbangan ekosistem kota, baik keseimbangan sistem hidrologi dan keseimbangan mikroklimat, maupun sistem ekologis lain yang dapat meningkatkan ketersediaan udara bersih yang diperlukan masyarakat, serta sekaligus dapat meningkatkan nilai estetika kota. Berikut sebaran ruang terbuka hijau, ruang terbuka biru, hutan bakau, badan air, dan sempadan sungai Kota Banda Aceh tahun 2009.

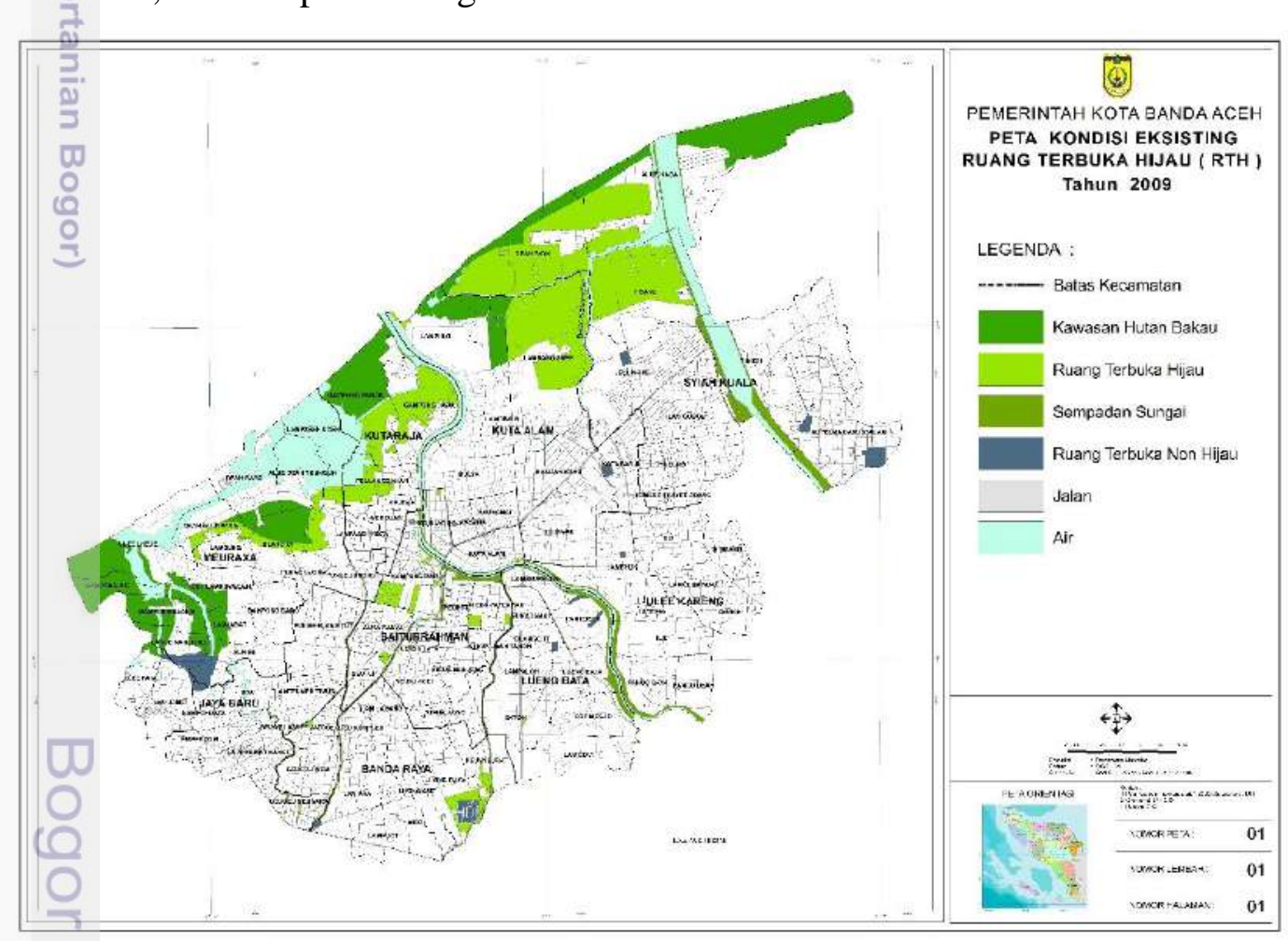

Gambar 2 Peta kondisi eksisting RTH Kota Banda Aceh 2009

(Sumber : Dinas Pekerjaan Umum Kota Banda Aceh) 


\section{Taman Kota}

Taman kota berdasarkan PermenPU No. 5 Tahun 2008 merupakan lahan T terbuka yang berfungsi sosial dan estetik sebagai sarana kegiatan rekreasi, edukasi, atau kegiatan lain pada tingkat kota. Taman kota ditujukan untuk melayani penduduk satu kota atau bagian wilayah kota. Taman ini melayani minimal 480.000 penduduk dengan standar minimal $0.3 \mathrm{~m}^{2}$ per penduduk kota, dengan luas taman minimal $144.000 \mathrm{~m}^{2}$. Taman ini dapat berbentuk sebagai lapangan hijau, yang dilengkapi dengan fasilitas rekreasi, taman bermain (anak/balita), taman bunga, taman khusus (untuk lansia), fasilitas olahraga terbatas, dan kompleks olahraga dengan minimal RTH $80 \%-90 \%$. Semua fasilitas tersebut terbuka untuk umum. Jenis vegetasi yang dipilih berupa pohon tahunan, perdu, dan semak yang ditanam secara berkelompok atau menyebar dan berfungsi sebagai pohon pencipta iklim mikro atau sebagai pembatas antar kegiatan. RTH taman kota dapat dimanfaatkan - masyarakat untuk melakukan berbagai kegiatan sosial pada satu kota atau bagian - wilayah kota. Bentuk-bentuk taman kota dapat berupa taman RT, taman RW, taman kelurahan, taman kecamatan, taman kota, dan hutan kota. Menurut Unterman dan Small (1986) taman dapat dikelompokkan menjadi tiga kategori berdasarkan sifat kepemilikānnya yaitu:

1. Taman publik (umum) yaitu taman yang dapat digunakan oleh umum.

2. Taman semi publik yaitu taman milik pribadi yang dapat digunakan oleh umüm atau dapat digunakan secara bersama-sama.

3. Taman pribadi yaitu taman milik pribadi yang tidak dapat digunakan oleh umūm.

Berdasarkan ukuran dan skala cakupan penggunanya, taman umum di perkotaan biasanya dibedakan atas taman kota, taman lingkungan, dan taman ketetanggaan. Taman kota adalah taman umum pada skala kota, yang peruntukkannya sebagai fasilitas untuk rekreasi, olahraga, dan sosialisasi masyarakat di kota yang bersangkutan. Fasilitas yang disediakan di taman kota disesuaikan dengan fungsinya dan fasilitas pendukung lainnya, meliputi:

1. Fasilitas rekreasi (fasilitas bermain anak, tempat bersantai, panggung, dan lain-lain).

2. Fasilitas olahraga (jogging track, kolam renang, lapangan bola, lapangan tenis, basket, volley, badminton, dan fasilitas refleksi).

3. Fasilitas sosialisasi (ruang piknik, ruang/fasilitas yang memungkinkan untuk sosialisasi baik untuk kelompok kecil maupun besar).

4. Fasilitas jalan, entrance, tampat parkir, mushola, tempat berjualan (tidak dominan), drainase, air, listrik/penerangan, penampungan sampah, dan toilet.

Lokasi taman ini biasanya pada lokasi yang strategis dan mudah diakses dari berbagai penjuru kota. Penanggung jawab taman kota adalah pemerintah kota, namun (dalam pengelolaannya dapat berkolaborasi dengan pihak swasta. Berdasarkan tata letaknya dalam kota, taman kota ini dikategorikan antara lain sebagai taman pertokoan, taman untuk kegiatan industri, taman lingkungan pemukiman, dan taman-taman rekreasi umum (Eckbo 1964). Selanjutnya, taman juga dikategorikan berdasarkan pengelolaannya, yang terdiri atas taman-taman 
privat, yaitu yang dimiliki dan dibiayai oleh individu dari kelompok masyarakat atau suatu perusahaan individu, dan taman-taman publik yaitu taman yang dikelola oleh pemerintah.

\section{Iklim Mikro}

Iklim mikro merupakan kondisi fisik lapisan atmosfer yang dekat dengan permukaan tanah atau di sekitar tanaman, seperti suhu, kelembapan, tekanan udara, keteduhan, dan dinamika energi radiasi surya. Iklim mikro nilainya dapat bersifat mudah untuk berubah-ubah. Cakupan dari iklim mikro bersifat sempit, misalnya hanya terbatas pada skala yang sempit, luasan beberapa meter/km persegi saja. Nilai dari iklim mikro juga mudah untuk berubah-ubah secara spasial maupun temporal. Tipe tanah juga mampu memengaruhi iklim mikro, karakteristik permukaan tanah juga penting, tanah dengan warna yang lebih terang lebih memantulkan dan kurang merespon terhadap pemanasan harian. Hal lain yang berpengaruh terhadap iklim mikro adalah kemampuan tanah untuk menyerap atau mempertahankan uap air, yang bergantung pada komposisi tanah dan penggunaannya. Keberadaan vegetasi juga: berperan penting untuk mengontrol penguapan air ke udara melalui proses transpirasi. Vegetasi atau tumbuhan bisa juga menutupi tanah di bawahnya dan memengaruhi perbedaan suhu. Tanaman atau vegetasi secara langsung memberikan pengaruh kepada kondisi iklim mikro yang ada melalui modifikasi radiasi matahari dan suhu tanah. Keberadaan tanaman juga memengaruhi tingkat evapotranspirasi (Villegas et al. 2010). Iklim mikro sangat memengaruhi kenyamanan manusia dan dapat dimodifikasi untuk memberikan kenyamanan bagi manusia. Modifikasi iklim mikro dapat dilakukan dengan memodifikasi elemen iklim mikro menggunakan elemen lanskap.

. Iklim mikro sangat dipengaruhi oleh faktor lokal di antaranya, karakteristik vegetasi, badan air, dan aktivitas manusia. Beberapa faktor pengendali iklim mikro di antaranya intensitas energi radiasi yang bervariasi terhadap lintang di suatu belahan bumi, albedo permukaan yang bervariasi dengan warna komposit dan karakteristiknya pada permukaan bumi, distribusi daratan dan lautan serta pengaruh pegunungan atau bentukan topografi dan angin (Miller el al 1993).

\section{Hubungan RTH dengan Kenyamanan Manusia}

Suhu udara memiliki kaitan dengan kenyamanan manusia. Semakin meningkatnya suhu udara atau semakin menurunnya suhu udara akan memberikan rasa tidak nyaman bagi manusia karena terlalu panas atau dingin (Hidayat 2010). Beberapa studi menyebutkan bahwa kawasan hijau memberikan pengaruh terhadap kenyamanan manusia melalui perubahan suhu udara. Metode THI hanya menitikberatkan terhadap faktor suhu udara dan kelembapan relatif saja tanpa melihat faktor kebiasaan manusia dalam makanan, pakaian, dan lainnya (Emmanuel 2005). Namun metode THI ini biasanya banyak digunakan di wilayah tropis terutama di luar ruangan. Umumnya di wilayah tropis manusia akan cenderung merasa nyaman pada nilai $20-26{ }^{\circ} \mathrm{C}$ dan sudah merasa tidak nyaman pada $\mathrm{THI}$ di atas $27^{\circ} \mathrm{C}$ (Effendy et al. 2006).

Kawasan hijau yang memberikan naungan yang dihasilkan oleh pepohonan dapat mengurangi silaunya sinar matahari dan menghalangi hamburan cahaya dari 
langit dan permukaan sekitar sehingga dapat mengubah pertukaran panas antara bangunan dan sekitarnya. Hasil penelitian Shahidan et al. (2010) menyatakan bahwa naungan yang diberikan oleh pohon akan memberikan kenyamanan untuk $\frac{\tau}{5}$ manusia ketika sedang duduk atau berjalan di bawahnya. Penelitian yang dilakukan oleh Tursilowati (2007) menunjukan bahwa pengurangan ruang terbuka hijau (RTH) di daerah Surabaya sebesar 9.2 \% dari tahun 1994 sampai 2002 mengakibatkan terjadinya peningkatan daerah yang memiliki kondisi tidak nyaman dari 16.082 Ha pada tahun 1994 menjadi 31.948 Ha pada tahun 2002. Hadi et al. (2012) dengan menggunakan indikator THI menyebutkan bahwa indeks kenyamanan di daerah yang memiliki kawasan hijau (RTH) akan menunjukkan kondisi yang lebih nyaman dibandingkan dengan daerah kota yang penuh dengan permukiman.

\section{Temperature Humidity Index (THI)}

Temperature Humidity Index atau dikenal juga dengan indeks kenyamanan adalah suatu metode yang digunakan untuk mengetahui adanya cekaman panas dan menetapkan efek dari kondisi panas pada kenyamanan manusia yang mengombinasikan suhu dan kelembapan. Pengaruh keadaan lingkungan fisik atmosfer atau iklim terhadap manusia dinyatakan dengan istilah kenyamanan. Beberapa_ahli telah berusaha untuk menyatakan pengaruh parameter-parameter iklim terhảadap kenyamanan manusia dengan bantuan persamaan yang mengandung dua atau lebih parameter iklim, misalnya indeks ketidaknyamanan (Tjasyono, 1996).

Faktor iklim yang memengaruhi kenyamanan manusia adalah suhu udara, radiasi matahari, curah hujan, dan kelembapan. Akan tetapi dalam penentuan tingkat kenyamanan suatu daerah atau wilayah tidak semua parameter iklim dapat digunakañ secara langsung. Berdasarkan hasil penelitian yang telah dilakukan oleh Wirasasmita et. al, (2003), indeks kenyamanan dapat dibedakan ke dalam tiga kondisi yäitu, kondisi nyaman berada pada kisaran nilai THI 19-23, kondisi sedang berada pada kisaran nilai THI 23-27, dan untuk kisaran nilai THI di atas 27 dinyatakan sebagai kondisi yang tidak nyaman.

\section{Estetika Lanskap}

Simonds (1983) menyatakan bahwa lanskap adalah suatu bentang alam dengan karakteristik tertentu yang dapat dinikmati oleh seluruh indera manusia dengan karakter yang menyatu secara alami dan harmonis untuk memperkuat karakter lanskap tersebut. Simonds juga menyatakan bahwa estetika merupakan hubungan yang harmonis dari semua elemen atau komponen yang dirasakan. Estetika dalam lanskap dapat berarti suatu keindahan yang dapat memengaruhi kualitas suatu lingkungan dan merupakan salah satu sumber daya alam (SDA) sehingga perlu dilestarikan dan ditingkatkan kualitasnya. Dalam hal ini manusia memegang peranan penting dalam merasakan suatu lanskap dan memberikan penilaian terhadap kualitas suatu lanskap. Kualitas dibentuk oleh karakter visual elemen pembentuknya, sedangkan estetika dapat didefinisikan sebagai suatu kondisi persepsi panca indera yang dapat mengubah perasaan seseorang. Menurut Booth (1983), estetika digunakan sebagai dasar dalam visual lanskap. Kualitas estetika lanskap dapat diukur berdasarkan penilaian manusia. Pemandangan suatu 
lanskap sangat sulit diukur secara objektif karena bersifat kualitatif, selain itu estetika bersifat subjektif bagi setiap orang.

Menurut Daniel dan Boster (1976), penilaian secara kualitatif tersebut dapat ditransformasikan menjadi nilai kuantitatif. Kualitas estetika suatu lanskap secara langsung dapat memberikan kepuasan pada seseorang, dan secara tidak langsung dapat memengaruhi perilaku manusia. Komponen dari suatu objek dalam menentukan tingkat estetikanya dapat ditentukan melalui dua penilaian, yaitu formal dan simbolik. Estetika formal menilai suatu objek berdasarkan bentuk, ukuran, warna, kompleksitas, dan keseimbangan suatu objek. Sementara itu, estetika simbolik menilai suatu objek berdasarkan pada makna konotatif dari objek tersebut setelah dialami oleh pengamat. Kualitas estetika berperan dalam membentuk karakter dan identitas suatu ruang. Kualitas estetika dari suatu ruang merupakan hasil dari kombinasi penampilan lanskap itu sendiri dengan proses psikologi yang meliputi tanggapan, pemahaman, dan emosi dari pengamat lanskap tersebut.

Scenic Beauty Estimation (SBE) merupakan metode untuk menilai suatu lanskap maupun objek lanskap berdasarkan keindahan yang disukai. Metode ini menggunakan kuesioner untuk mengetahui persepsi dan preferensi masyarakat terhadap suatu lanskap tertentu. Penerapan metode SBE terdiri atas tiga langkah utama, yaitu pengambilan foto lanskap, presentasi slide foto, dan analisis data (Daniel dan Boster 1976). Metode SBE mengukur preferensi masyarakat dengan penilaian melalui sistem rating dengan skala 1-10 terhadap slide foto. Lanskap akan semakin baik apabila mampu mengaplikasikan prinsip-prinsip desain seperti kesêimbangan (balance), keselarasan (harmony), irama/pengulangan (rhythm), penekanan (emphasis), kesederhanaan, kontras, proporsi, dan kesatuan (unity).

\section{METODE}

\section{Lokasi dan Waktu Penelitian}

Penelitian ini dilaksanakan pada ruang terbuka hijau (RTH) di Kota Banda Aceh yang berbentuk taman kota. Lokasi yang dipilih adalah Taman Putroe Phang (TPP), Lapangan Blang Padang (LBP), dan Hutan Kota BNI (HKB). Ketiga lokasi tersebut dipilih karena memiliki karakter yang berbeda, baik dari segi fungsi/pemanfaatan, luas, sejarah, desain, maupun pemilihan jenis tanamannya. Masing-masing lokasi tersebut juga dibangun pada tahun yang rentangnya cukup jauh, sehingga dapat menjadi perbandingan berdasarkan skala waktu berdirinya taman tersebut. Ketiga taman kota tersebut merupakan taman yang intensitas penggunaannya tinggi serta difungsikan dengan sangat baik. Selain itu, taman tersebut terletak di daerah dengan mobilitas perkotaan yang relatif tinggi. Harapannya, ketiga lokasi tersebut dapat mewakili keadaan lingkungan taman kota di Kota Banda Aceh. Pengumpulan data primer dan survei lapang dimulai sejak bulan Februari 2015 hingga bulan Maret 2015. Peta lokasi penelitian dapat dilihat pada gambar berikut ini. 


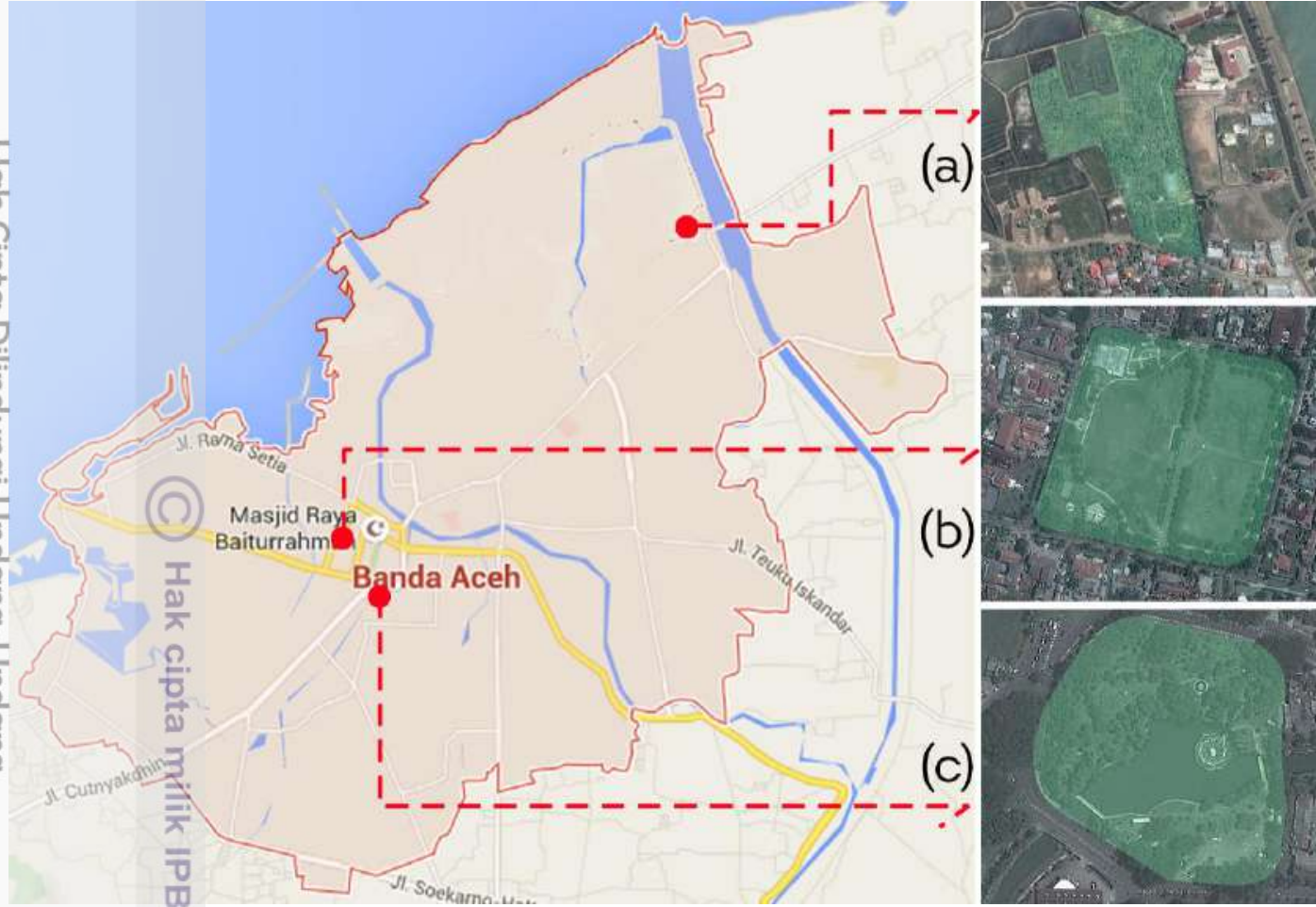

Gambar $3 \pm$ tokasi penelitian: (a) Hutan Kota BNI, (b) Lapangan Blang Padang, dan (c) Taman Putroe Phang

\section{Alat dan Bahan}

Seläma pengumpulan data primer dan sekunder, alat dan bahan yang digunakan terdiri atas perangkat keras (hardware) dan perangkat lunak (software). Berikut alat dan bahan yang digunakan (tabel 1).

00

Tabel 1 Alat yang digunakan dalam penelitian

\begin{tabular}{|c|c|c|}
\hline No. & Hardware & Fungsi \\
\hline 1 & Kamera & Pengambilan foto pada tapak \\
\hline 2 & $\begin{array}{l}\text { Global Positioning System } \\
\text { (GPS) }\end{array}$ & Ground check dan penitikan lokasi penting \\
\hline 3 & Thermo Hygrometer & Mengukur suhu dan kelembapan udara \\
\hline 4 & Laptop & Mengolah data \\
\hline 5 & Alat gambar & Sketsa gambar tapak \\
\hline No. & Software & Fungsi \\
\hline 1 & SPSS Statistics 17.0 & Pengolahan data statistik \\
\hline 2 & Google Earth & Pendeleniasian tapak \\
\hline 3 & MS Office 2013 & Pengetikan penyusunan, pengolahan data skripsi \\
\hline 4 & AutoCad 2013 & Penyusunan peta tapak \\
\hline 5 & Photoshop CC & Penyusunan layout denah tapak \\
\hline
\end{tabular}

Metode Penelitian

Metode penelitian yang digunakan adalah metode secara deskriptif. Evaluasi yang dilakukan terkait pada dua aspek, yaitu aspek kenyamanan termal dan aspek estetika pada tiga taman kota di Banda Aceh. Pengumpulan data dilakukan dengan 
cara pengukuran dan pengamatan di lapang, wawancara dengan pihak terkait, data sekunder, penyebaran kuesioner, dan studi literatur. Pengukuran yang dilakukan di lapang berupa suhu dan kelembapan udara pada beberapa titik penutupan yang berbeda. Pengamatan vegetasi, pemotretan kondisi eksisting, dan pemotretan mewakili keadaan lokasi tersebut sebagai bahan foto untuk penilaian kualitas estetika (Gambar 4). Sisanya melakukan pengumpulan data melalui wawancara kepada pihak terkait dan kuesioner. Keseluruhan metode dibagi menjadi 4 tahapan besar yaitu persiapan, inventarisasi, evaluasi, dan rekomendasi.

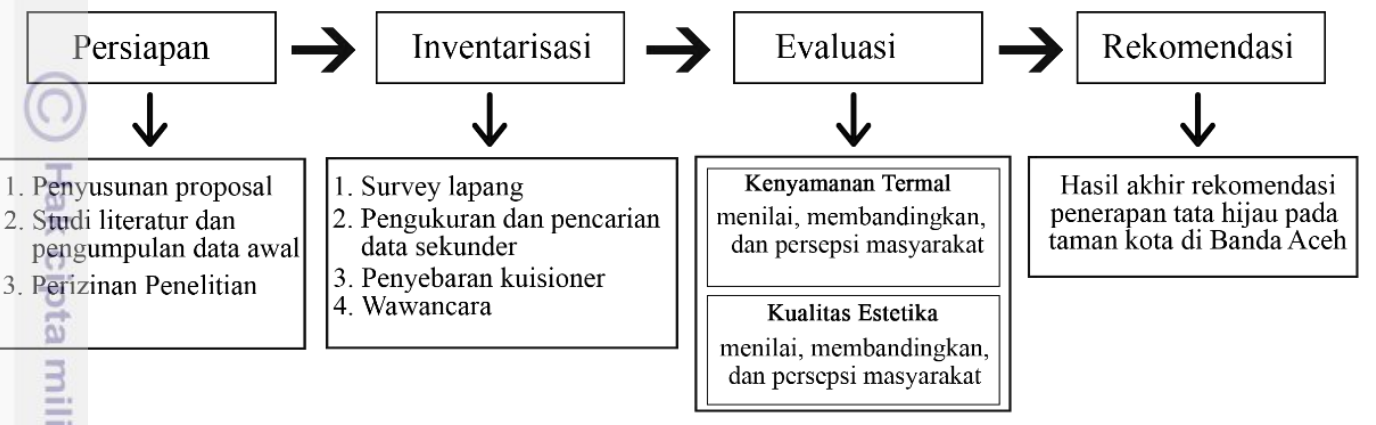

Gambar 4 Diagram proses penelitian

\section{1. $\overparen{\overline{\text { Persiapan }}}$}

Tahapan ini merupakan awal dari proses penyelesaian tugas akhir. Tahapan ini diawali oleh penentuan tema penelitian pada mata kuliah teknik penulisan ilmiah, persiapan penentuan lokasi hingga judul penelitian, kemudian dilanjutkan dengan pembuatan proposal dan konsultasi dengan dosen pembimbing skripsi, perumusan tahapan penelitian, kolokium, persiapan alat dan bahan yang akan digunakan, studi pustaka, serta perizinan dengan pihak terkait.

\section{Inventarisasi}

ㄱ Tahapan ini merupakan tahap mengumpulkan data dan informasi terkait taman kota yang diteliti di Banda Aceh. Pengumpulan data terdiri atas data primer dan data sekunder. Data primer meliputi pengukuran suhu udara, kelembapan udara, pemotretan suasana tapak, wawancara, dan pengumpulan data kuesioner. Sementara itu, data sekunder diperoleh dari instansi maupun lembaga yang memiliki informasi penting mengenai tapak. Metode pengumpulan data dan informasi tapak menggunakan teknik survei dan peninjauan studi pustaka dengan jenis dan sumber data yang digunakan dijelaskan pada Tabel 2.

Tabel 2 Jenis dan sumber data yang digunakan

\begin{tabular}{|c|c|c|c|}
\hline No. & Jenis Data & Kegunaan & Sumber \\
\hline & Letak geografis & Peta dasar lokasi penelitian & $\begin{array}{l}\text { Bappeda Banda Aceh, Dinas } \\
\text { Kebersihan dan Keindahan }\end{array}$ \\
\hline$\frac{28}{0}$ & Data vegetasi & $\begin{array}{l}\text { Mengidentifikasi jumlah, } \\
\text { sebaran, jenis, dan nama } \\
\text { vegetasi }\end{array}$ & $\begin{array}{l}\text { Survei lapang, Dinas } \\
\text { Kebersihan dan Keindahan }\end{array}$ \\
\hline 3. & Iklim & $\begin{array}{l}\text { Menganalisis pengaruh suhu } \\
\text { dan kelembapan }\end{array}$ & Pengukuran dan BMKG \\
\hline
\end{tabular}


Tabel 2 Jenis dan sumber data yang digunakan (lanjutan)

\begin{tabular}{|c|c|c|c|}
\hline No. & Jenis Data & Kegunaan & Sumber \\
\hline 4. & Foto tapak & $\begin{array}{l}\text { Memganalisis kualitas } \\
\text { estetika }\end{array}$ & Survei lapang \\
\hline 5. & $\begin{array}{l}\text { Persepsi dan } \\
\text { preferensi } \\
\text { pengunjung }\end{array}$ & $\begin{array}{l}\text { Masukan sebagai } \\
\text { rekomendasi untuk } \\
\text { pengembagan taman kota }\end{array}$ & Pengunjung \\
\hline 6. & $\begin{array}{l}\text { Pemanfaatan } \\
\text { taman kota }\end{array}$ & $\begin{array}{l}\text { Masukan sebagai } \\
\text { rekomendasi untuk } \\
\text { pengembangan taman kota }\end{array}$ & Pengunjung dan pengelola \\
\hline
\end{tabular}

\section{Pengukuran Iklim Mikro (Suhu dan Kelembapan Udara)}

Pengukuran suhu dan kelembapan udara dilaksanakan pada bulan Februari 2015. Pengukuran di setiap taman dilakukan saat pagi, siang, dan sore hari sebanyak tiga kali ullangan pada hari yang berbeda dengan kondisi hari cerah, tidak hujan maupun mendung. Pengukuran pagi hari dilaksanakan mulai pukul 07.30-08.30 WIB, pada siang hari berkisar antara 12.00-13.00 WIB, dan pada sore hari pukul 17.30-18.30 WIB. Pengukuran tersebut dilakukan pada beberapa jenis penutupan, baik di dalam maupun luar taman kota. Pengukuran di dalam taman dilakukan pada beberapa jenis tutupan yakni, naungan pohon, tutupan rumput, dan perkerasan. Sementara itu, pengukuran di luar taman dilakukan di atas jalan raya yang sekelilingnya merupakan bangunan dan berjarak 30-300 m dari batas taman. Penentuan titik-titik tersebut ditentukan secara acak tersebar merata. Berikut adalah diagram pengukuran suhu dan kelembapan pada tiga bentuk taman kota di Taman Putroe Phang (TPP), Lapangan Blang Padang (LBP), dan Hutan Kota BNI (HKB).

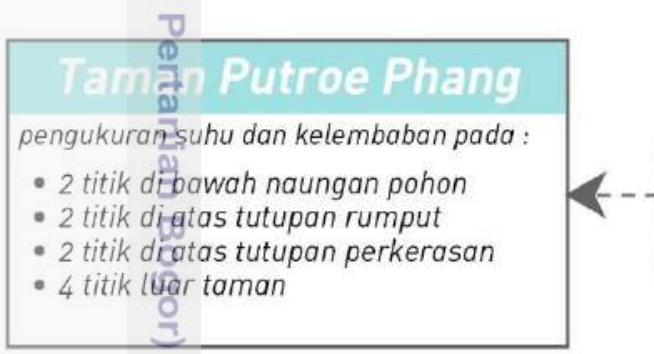

Jumat, 6 Feb 2015 Jumat, 13 Feb 2015 Selasa, 24 Feb 2015 Selasa, 24 feb 2015
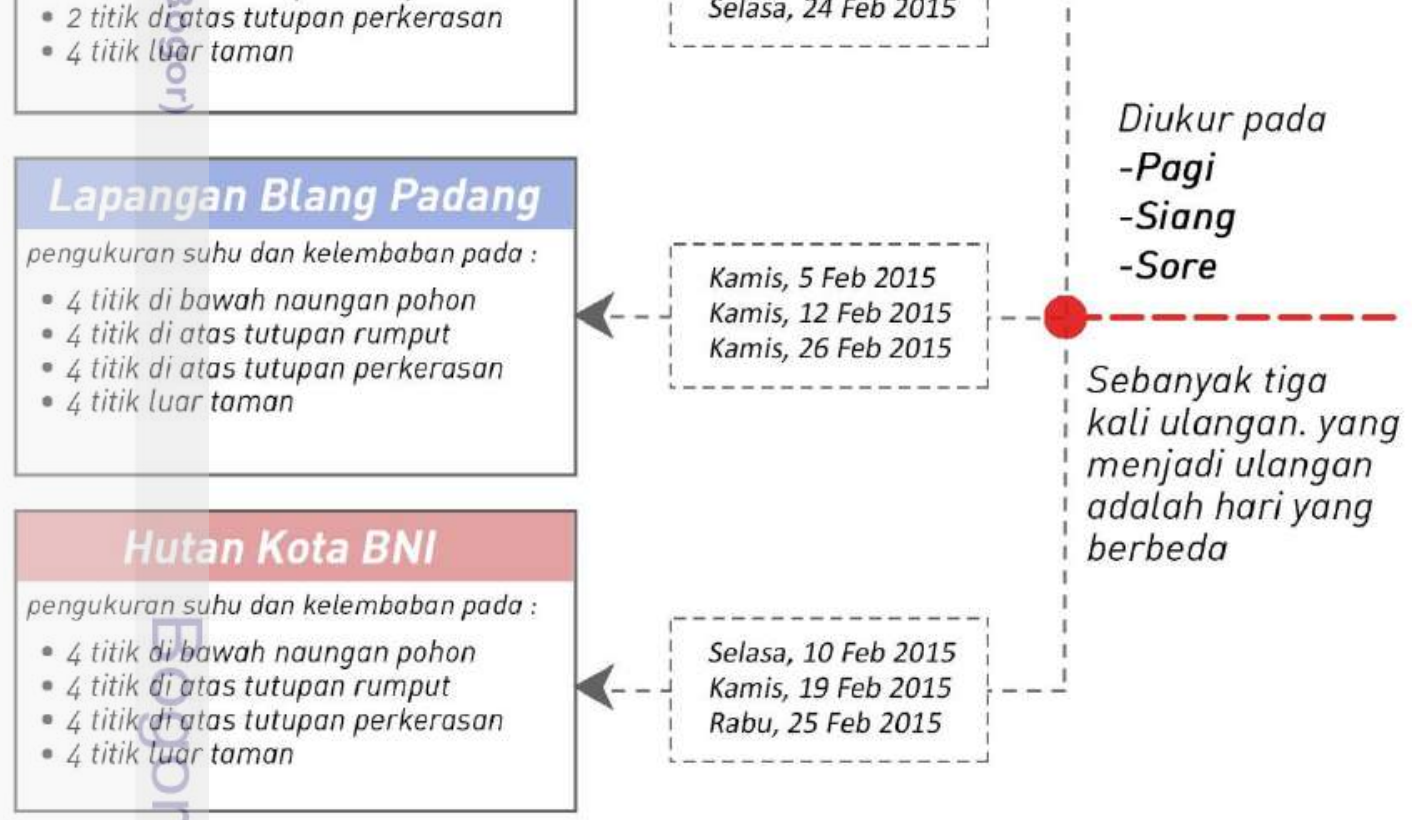

Gambar 5 Sistem pengukuran suhu dan kelembapan 
Tabel 3 Lokasi area pengukuran suhu dan kelembapan di Taman Putroe Phang

\begin{tabular}{|c|c|c|}
\hline No & Area Ukur & Deskripsi \\
\hline 1. & Area Rumput (1.1) & $\begin{array}{l}\text { Rumput Zoysia matrella di area playground, jarak } \\
10 \mathrm{~m} \text { dari pedestrian. }\end{array}$ \\
\hline 2. & Area Rumput (1.2) & $\begin{array}{l}\text { Rumput Zoysia matrella di sebelah barat dari } \\
\text { bangunan pusat informasi dengan jarak } 5 \mathrm{~m} \text { dari tepi } \\
\text { bangunan. }\end{array}$ \\
\hline 3. & Perkerasan (2.1) & $\begin{array}{l}\text { Di atas perkerasan berupa jembatan gantung } \\
\text { berbahan baja yang terletak di sebelah barat taman. }\end{array}$ \\
\hline 4. & Perkerasan (2.2) & $\begin{array}{l}\text { Perkerasan berupa keramik outdoor dengan jarak } 3 \mathrm{~m} \\
\text { dari Pinto Khop, sekitarnya adalah plaza. }\end{array}$ \\
\hline & $\begin{array}{l}\text { Bawah Naungan } \\
(3.1)\end{array}$ & $\begin{array}{l}\text { Naungan pohon Ficus benjamina yang terletak di } \\
\text { sebelah barat taman, berjarak } 7 \mathrm{~m} \text { dari batas pagar. }\end{array}$ \\
\hline 6. $\frac{\pi}{\frac{\pi}{2}}$ & $\begin{array}{l}\text { Bawah Naungan } \\
(3.2)\end{array}$ & $\begin{array}{l}\text { Naungan pohon Mimusoph elengi yang terletak di } \\
\text { sebelah timur laut taman, berjarak } 3 \text { m dari batas } \\
\text { pagar. }\end{array}$ \\
\hline 7. 클 & Luar (4.1) & $\begin{array}{l}\text { Atas jalan raya, di sekelilingnya terdapat pohon } \\
\text { naungan pada pulau jalan. }\end{array}$ \\
\hline 8. $\bar{\varpi}$ & Luar (4.2) & $\begin{array}{l}\text { Atas jalan raya, di sekelilingnya terdapat bangunan } \\
\text { SPBU. }\end{array}$ \\
\hline 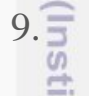 & Luar (4.3) & $\begin{array}{l}\text { Atas jalan raya, di sekelilingnya terdapat bangunan } \\
\text { kantor. }\end{array}$ \\
\hline 10 & Luar (4.4) & $\begin{array}{l}\text { Atas jalan raya, di sekelilingnya terdapat bangunan } \\
\text { kantor. }\end{array}$ \\
\hline
\end{tabular}

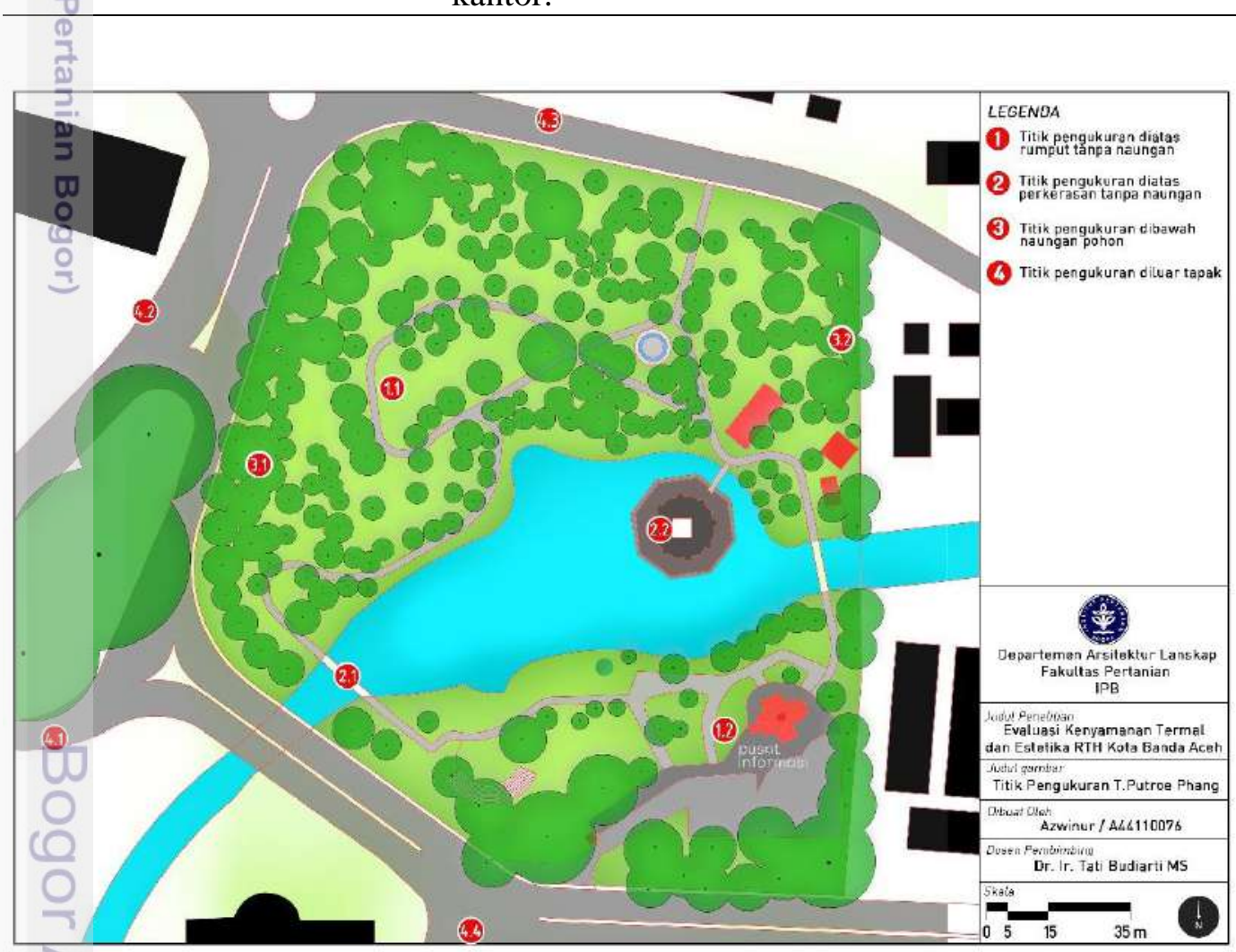

Gambar 6 Area pengukuran suhu dan kelembapan di Taman Putroe Phang 
Tabel 4 Lokasi pengukuran suhu dan kelembapan di Lapangan Blang Padang

\begin{tabular}{|c|c|c|}
\hline No & Area Ukur & Deskripsi \\
\hline 1. & $\begin{array}{l}\text { Area Rumput } \\
(1.1)\end{array}$ & $\begin{array}{l}\text { Di atas rumput Zoysia matrella, berjarak } 60 \mathrm{~m} \text { dari } \\
\text { monumen pesawat dan } 30 \mathrm{~m} \text { dari jalan utama di } \\
\text { tengah lapangan. }\end{array}$ \\
\hline 2. & $\begin{array}{l}\text { Area Rumput } \\
(1.2)\end{array}$ & $\begin{array}{l}\text { Di atas rumput Zoysia matrella, berjarak } 70 \mathrm{~m} \text { dari } \\
\text { batas tapak sisi barat, dan } 100 \mathrm{~m} \text { dari batas sisi utara. }\end{array}$ \\
\hline 3. & $\begin{array}{l}\text { Area Rumput } \\
\text { (1.3) }\end{array}$ & $\begin{array}{l}\text { Di atas rumput Zoysia matrella, sebelah timur laut } \\
\text { dari tapak, berjarak } 70 \mathrm{~m} \text { dari batas sisi timur dan } 58 \\
\mathrm{~m} \text { dari sisi utara. }\end{array}$ \\
\hline 4. & $\begin{array}{l}\text { Area Rumput } \\
(1 . \overline{4})\end{array}$ & $\begin{array}{l}\text { Di atas rumput Zoysia matrella, berjarak } 6 \mathrm{~m} \text { dari } \\
\text { jalan yang membelah dari barat ke timur. }\end{array}$ \\
\hline 5. & Perkerasan $(2.1)$ & $\begin{array}{l}\text { Lapangan basket, lantai berbahan material beton cor, } \\
\text { sekitarnya merupakan tribun penonton dari bahan } \\
\text { beton. }\end{array}$ \\
\hline 6. & Perkerasan (2.2) & Lapangan takraw, meterial dari semen cor. \\
\hline 7. & Perkerasan $(2.3)$ & $\begin{array}{l}\text { Di tengah jalan dalam lapangan, lebar } 9 \mathrm{~m} \text {, material } \\
\text { aspal, sekitarnya adalah tegakan pohon Pterocarpus } \\
\text { indicus. }\end{array}$ \\
\hline 8. & Perkerasan $(2.4)$ & $\begin{array}{l}\text { Di tengah jalan utama dalam lapangan, lebar } 4 \mathrm{~m} \text {, } \\
\text { material aspal. }\end{array}$ \\
\hline 9. & $\begin{array}{l}\text { Baw̄ah Naungan } \\
\left(3 . \frac{1}{7}\right) \\
\frac{0}{3}\end{array}$ & $\begin{array}{l}\text { Naungan pohon Samanea saman bertajuk spreading, } \\
\text { terletak sebelah barat daya dari tapak, berjarak } 12 \mathrm{~m} \\
\text { dari sisi selatan, dan } 13 \mathrm{~m} \text { dari sisi barat. }\end{array}$ \\
\hline 10. & $\begin{array}{l}\text { Baw̄ah Naungan } \\
(3.2)\end{array}$ & $\begin{array}{l}\text { Naungan pohon Samanea saman bertajuk spreading, } \\
\text { sekitarnya merupakan jalur jogging dan playground. }\end{array}$ \\
\hline 11. & $\begin{array}{l}\text { Bawah Naungan } \\
(3.3)\end{array}$ & $\begin{array}{l}\text { Naungan pohon Pterocarpus indicus, terletak di } \\
\text { sudut timur laut dari tapak, sekitarnya adalah Phoenix } \\
\text { dactylifera, Samanea saman, jalur jogging dan jalan } \\
\text { raya. }\end{array}$ \\
\hline 12. & $\begin{array}{l}\text { Bawah Naungan } \\
(3.4)\end{array}$ & $\begin{array}{l}\text { Naungan pohon Pterocarpus indicus, terletak di } \\
\text { samping jalan keluar dari lapangan. }\end{array}$ \\
\hline 13. & Luar (4.1) & $\begin{array}{l}\text { Atas jalan raya, di sekelilingnya terdapat bangunan } \\
\text { kantor dan rumah. }\end{array}$ \\
\hline 14. & Luar (4.2) & $\begin{array}{l}\text { Atas jalan raya, di sekelilingnya terdapat bangunan } \\
\text { kantor dan rumah. }\end{array}$ \\
\hline 15. & Luar (4.3) & $\begin{array}{l}\text { Atas jalan raya, di sekelilingnya terdapat bangunan } \\
\text { kantor dan sekolah. }\end{array}$ \\
\hline 16. & Luar (4.4) & $\begin{array}{l}\text { Atas jalan raya, di sekelilingnya terdapat bangunan } \\
\text { kantor dan rumah sakit. }\end{array}$ \\
\hline
\end{tabular}




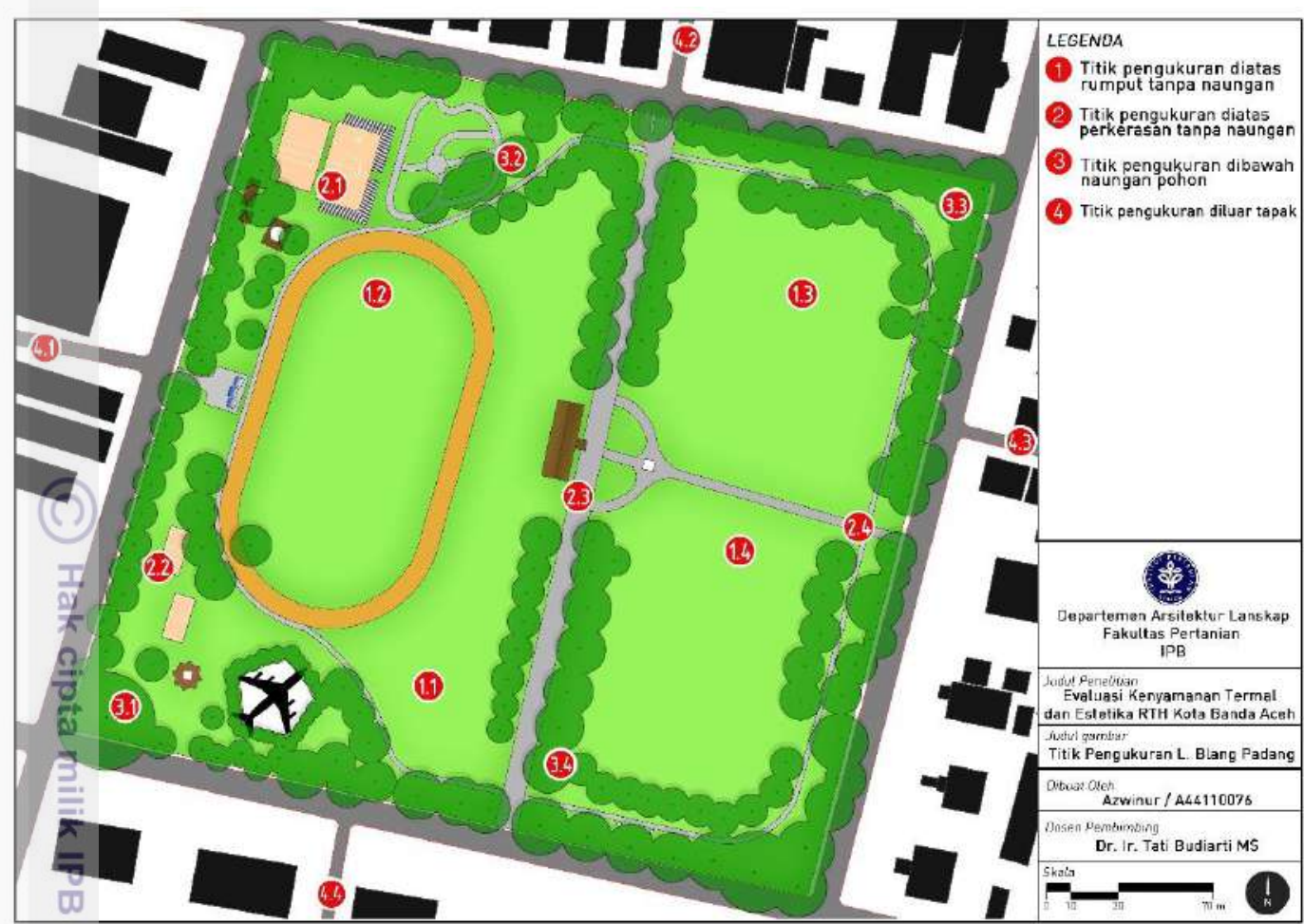

Gambar 7 Area pengukuran suhu dan kelembapan di Lapangan Blang Padang

Tabel 5 Lokasi pengukuran suhu dan kelembapan di Hutan Kota BNI

\begin{tabular}{|c|c|c|}
\hline $\mathrm{N} \otimes$ & Area Ukur & Deskripsi \\
\hline $1 \stackrel{\frac{0}{3}}{\frac{0}{3}}$ & Area Rumput (1.1) & $\begin{array}{l}\text { Area berumput, sekelilingnya terdapat pepohonan, } \\
\text { area ini berjarak } 53 \mathrm{~m} \text { dari pagar sebelah barat. }\end{array}$ \\
\hline 2.j & Area Rumput (1.2) & $\begin{array}{l}\text { Area berumput, sekelilingnya terdapat pepohonan, } \\
\text { area ini terletak di sebelah utara tapak. }\end{array}$ \\
\hline 3. & Area Rumput (1.3) & $\begin{array}{l}\text { Area berumput, sekelilingnya padang rumput dan } \\
\text { tambak, area ini terletak di sebelah timur tapak. }\end{array}$ \\
\hline 4. & Area Rumput (1.4) & $\begin{array}{l}\text { Area berumput, sekelilingnya terdapat pepohonan, } \\
\text { area ini terletak di sebelah tenggara tapak. }\end{array}$ \\
\hline 5 . & Perkerasan (2.1) & Plaza pada area welcome area. \\
\hline 6 . & Perkerasan (2.2) & Jalur batu kerikil menuju deck. \\
\hline 7. & Perkerasan (2.3) & Di atas deck kayu, terletak di area tambak. \\
\hline 8 . & Perkerasan (2.4) & Perkerasan jalan cor sebelah selatan dari kawasan. \\
\hline 9. & $\begin{array}{l}\text { Bawah Naungan } \\
(3.1)\end{array}$ & $\begin{array}{l}\text { Naungan pohon Ficus lyrata bertajuk bulat, sekitar } \\
\text { area pintu 2, terletak di sebelah barat kawasan. }\end{array}$ \\
\hline 10 & $\begin{array}{l}\text { Bawah Naungan } \\
(3.2)\end{array}$ & $\begin{array}{l}\text { Naungan pohon Terminalia catappa terletak di } \\
\text { tengah-tengah kawasan. }\end{array}$ \\
\hline- & $\begin{array}{l}\text { Bawah Naungan } \\
\text { (3.3) }\end{array}$ & $\begin{array}{l}\text { Naungan pohon Casuarina equisetifolia terletak di } \\
\text { sebelah utara kawasan. }\end{array}$ \\
\hline & $\begin{array}{l}\text { Bawah Naungan } \\
(3.4)\end{array}$ & $\begin{array}{l}\text { Naungan pohon Bucida molineti terletak di sebelah } \\
\text { selatan kawasan. }\end{array}$ \\
\hline
\end{tabular}


16

Tabel 5 Lokasi pengukuran suhu dan kelembapan di Hutan Kota BNI (lanjutan)

No Area Ukur Deskripsi

13. Luar (4.1) Atas jalan raya, di sekelilingnya terdapat perumahan dan lahan kosong.

14. Luar (4.2)

Atas jalan raya, di sekelilingnya terdapat perumahan.

15. Luar (4.3)

Atas jalan raya, di sekelilingnya terdapat rumah.

16. Luar (4.4)

Atas jalan, di sekelilingnya terdapat bangunan kampus UUI.

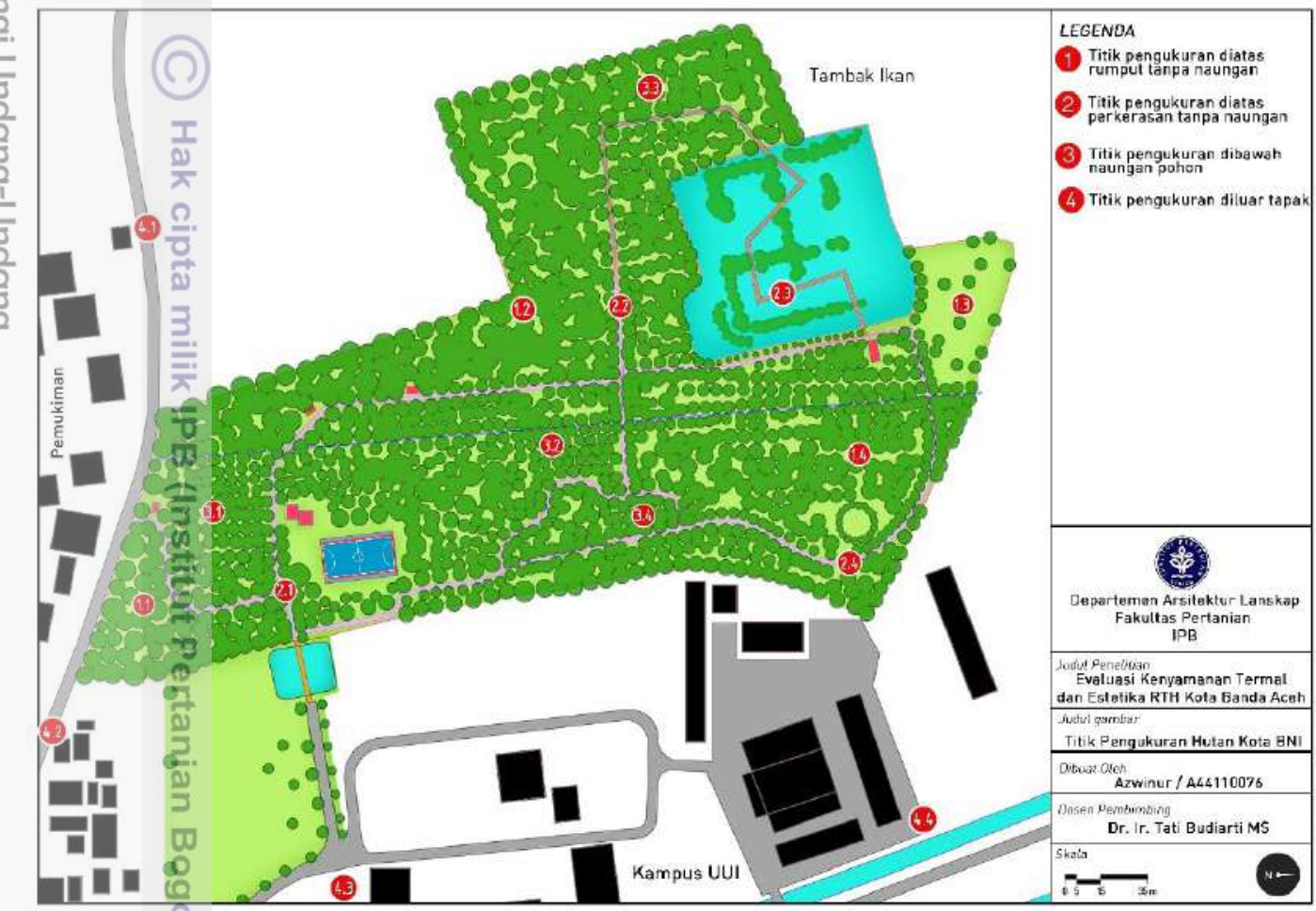

Gambar 8 Area pengukuran suhu dan kelembapan di Hutan Kota BNI

\section{Pemotretan Lanskap}

Pemotretan lanskap digunakan untuk penilaian kualitas estetika dari tiga lokasi tersebut. Pemotretan dilakukan pada setiap titik yang memiliki visual atau tampilan yang berbeda. Titik pemotretan dipilih secara acak mengikuti jalur-jalur pedestrian yang ada di dalam taman serta keterwakilan semua area/ruang dengan fungsi yang bermacam-macam yang ada di dalam taman. Titik pemotretan dilakukan dengan posisi sudut pandang sejajar dan arah pandang setinggi pandangan manusia Setiap lokasi diambil sebanyak 30 foto lanskap dengan total keseluruhan 90 foto. Ukuran gambar yang diambil sebesar 4320 x 3240 pixels.

\section{Penyebaran Kuesioner}

Terdapat dua jenis kuesioner yang digunakan pada penelitian ini yang ditujukan kepada jenis responden yang berbeda. Kuesioner jenis pertama ditujukan kepada pengunjung yang berada di setiap taman. Kuesioner yang diberikan berisi tanggapan serta saran responden/pengunjung terhadap persepsi dan preferensi responden/pengunjung mengenai kualitas kenyamanan termal dan kualitas estetika 
taman. Kuesioner diberikan kepada 30 responden/pengunjung pada masing-masing lokasi penelitian dengan cara random sampling. Sementara itu, kuesioner jenis kedua ditujukan kepada tenaga ahli yang mengerti tentang lanskap, dalam hal ini yang ditunjuk adalah mahasiswa Arsitektur Lanskap semester 6 dan 8 sebagai responden untuk menilai kualitas estetika. Pemilihan responden yang ahli dan sudah mengerti ilmu lanskap dalam menilai kualitas estetika tersebut dipilih agar hasil yang diperoleh akan semakin valid. Responden tersebut dipilih sebanyak 50 responden dengan cara random sampling dan setiap responden menilai 90 foto lanskap yang mewakili ketiga lokasi penelitian.

\section{Evaluasi}

Evaluasi yang dilakukan pada penelitian meliputi dua hal, yakni evaluasi kenyamanan termal dan kualitas estetika melalui analisis deskriptif dan kualitatif. Aspek kenyamanan termal dan kualitas estetika dievaluasi melalui metode yang didapat dari berbagai sumber dan literatur. Hasil evaluasi tersebut selanjutnya dapat digunakan untuk menentukan rekomendasi dalam meningkatkan kenyamanan termal dan kualitas visual taman kota.

\section{Eváluasi Kenyamanan Termal}

Rata-rata hasil pengukuran di setiap titik pengamatan dibuat dalam bentuk tabulasi sehingga akan diperoleh rata-rata hasil pengukuran pada setiap waktu pengukuran dengan menggunakan rumus (Handoko 1995):

$$
\mathrm{T}=\left(\mathrm{T}_{\text {maks }}+\mathrm{T}_{\min }\right) / 2
$$

Keterangan :

$\mathrm{T}_{\text {maks }} \quad$ : suhu udara maksimum pada setiap titik pengukuran $\left({ }^{\circ} \mathrm{C}\right)$

$\mathrm{T}_{\min } \quad$ : suhu udara minimum pada setiap titik pengukuran $\left({ }^{\circ} \mathrm{C}\right)$

Suhu rata-rata pada hari tertentu berdasarkan suhu yang diamati (Tmaks, Tmin, i, Tpagi, Tsiang, Tsore). Rumus yang digunakan adalah:

$$
\mathrm{T}=(2 \mathrm{~T} \text { pagi }+\mathrm{Tsiang}+\mathrm{T} \text { sore }) / 4
$$

Kelembapan rata-rata pada hari tertentu dapat diketahui dengan menjumlah nilai kelembapan pada titik pengamatan, kemudian dibagi dengan banyaknya titik pengamatan dengan rumus:

$$
\mathrm{RH}=\mathrm{RH} / 3 \quad \mathrm{i}=1,2,3 \ldots \ldots
$$

Hubungan evaluasi kenyamanan termal menggunakan perhitungan THI (Temperature Humidity Index). Nilai THI dapat ditentukan dari nilai suhu udara dan kelembapan relatif (RH) dengan persamaan Nieuwolt (1975):

$$
T H I=\left(0.8 \times T_{a}\right)+\left(\frac{R H X T_{a}}{500}\right)
$$

Keterangan:

THI = Temperature Humidity Index

$T_{a}=$ Suhu udara $\left({ }^{\circ} \mathrm{C}\right)$

$\mathrm{RH}=$ Kelembapan relatif $(\%)$ 
Data hasil penelitian mengenai suhu udara dan kelembapan udara dianalisis secara statistik untuk mengetahui adanya perbedaan pada setiap perlakuan (waktu pengukuran, area ukur) dan untuk mengetahui adanya interaksi pada setiap - perlakuan (waktu pengukuran, area ukur). Uji statistik yang digunakan yaitu Uji Anova dan apabila hasil analisis menunjukkan pengaruh nyata maka dilakukan analisis lebih lanjut dengan Duncan's Multiple Range Test (DMRT) pada taraf $5 \%$. Waktu pengukuran dan area ukur pada penelitian ini terdiri atas:

Waktu pengukuran:

Area ukur:

Pagi hari

Siang hari

- $\mathrm{P}=$ Perkerasan.

- $\mathrm{TR}=$ Di atas Rumput.

- NP = Naungan Pohon.

- L = Luar Taman

Pengkategorian kenyamanan termal pada area taman ke dalam kategori nyaman maupun tidak nyaman dilakukan dengan cara membandingkan nilai dari Hasil TH yang diukur dengan beberapa literatur terkait tingkat kenyamanan manusia pada lingkungan tropis. Dalam hal ini yang digunakan adalah kategori kenyamañan menurut penelitian yang dilakukan oleh Emmanuel 2005 dengan mengategorikan nyaman $(21 \leq \mathrm{THI} \leq 24)$, cukup nyaman $(24<\mathrm{THI} \leq 27)$, dan tidak nyaman (THI>27). Selain itu, aspek persepsi pengunjung tentang kenyamanan juga menjadi bahan pertimbangan. Tahap selanjutnya adalah mengukur pengaruh keberadaân taman terhadap fungsi pengontrol iklim mikro. Tahapan ini dilakukan dengan căra membandingkan pengukuran suhu di dalam dan di luar taman. Hasil dari selisih suhu tersebut dapat menunjukkan nilai manfaat dari taman terhadap penurunañ suhu udara pada area di sekitar taman.

\section{Evaluasi-Kualitas Estetika}

Evaluasi kualitas estetika pada taman menggunakan metode penilaian Scenic Beauty Estimation (SBE) oleh Daniel dan Boster (1976). Tahapannya adalah pengambilan foto lanskap sebanyak 30 foto pada setiap taman, persentasi slide foto sekaligus penilaian oleh responden melalui kuesioner tersebut. Tahap berikutnya yakni analisis data dengan responden yang merupakan mahasiswa arsitektur lanskap berjumlah 50 responden. Responden menilai setiap foto yang ditampilkan dengan skala nilai 1-10 (rendah-tinggi). Hasilnya diformulasikan dengan rumus:

$$
Z_{i j}=\frac{R_{i, j}-\bar{R}_{j}}{S_{j}}
$$

\section{Keterangan:}

$Z_{i j}=$ standar penilaian untuk nilai respon ke $\mathrm{i}$ oleh responden $\mathrm{j}$

$\bar{R}_{j}=$ nilai rata-rata dari semua nilai oleh responden $\mathrm{j}$

$R_{i, j}=$ nilai $\mathrm{i}$ dari responden $\mathrm{j}$

$S_{j} \quad=$ standar deviasi dari seluruh nilai oleh responden $\mathrm{j}$

$$
S B E_{x}=\left(Z L_{x}-Z L_{s}\right) \times 100
$$


Keterangan:

SBEx = Nilai SBE lanskap ke $\mathrm{x}$

ZLX = Nilai rata-rata Z lanskap ke $\mathrm{x}$

ZLs = Nilai rata-rata Z lanskap standar

Hasil yang diperoleh di atas kemudian dikelompokkan menurut skala Likert. Klasifikasi kualitas estetika dibagi menjadi kualitas estetika rendah, estetika sedang, dan estetika tinggi. Rentang Kelas dihitung dengan rumus

$$
\mathrm{R}=\frac{\mathrm{S} \max -\mathrm{S} \min }{K}
$$

Keterangan : Smax $=$ nilai tertinggi

Smin = nilai terendah

$\mathrm{K} \quad=$ rentan kelas yang digunakan

\section{Evaluasi Persepsi dan Preferensi Pengunjung}

Evaluasi persepsi dan preferensi pengunjung didapatkan dari data hasil penyebaran kuesioner kepada pengunjung pada setiap lokasi penelitian. Isi dari kuesioner terdiri atas identitas/karakteristik responden, persepsi, dan preferensi/keinginan responden terhadap lokasi penelitian (tujuan, frekuensi kunjungan, jarak taman dari tempat tinggal, waktu mengunjungi, lama berkunjung, kesan), dan saran responden terhadap lokasi penelitian. Hasil evaluasi persepsi dan preferensi pengunjung berupa analisis deskriptif yang tergambar dalam diagram ataw bagan yang mewakili persepsi dan preferensi pengunjung terhadap ruang terbuka hijau (taman kota) yang terdapat pada setiap lokasi penelitian.

\section{Rekomendasi}

Rekomendasi berisi sintesis dari hasil evaluasi kenyamanan termal dan kuáfitas estetika pada ruang terbuka hijau (taman kota) di Kota Banda Aceh. Sintesis dari hasil evaluasi tiga taman kota tersebut menjadi gambaran untuk perbaikan dan pengembangan taman kota yang menjadi lokasi penelitian, maupun taman-taman kota lain yang akan dikembangkan di Kota Banda Aceh. Hasil rekomendasi ini nantinya menjadi bahan masukan maupun usulan bagi pemerintah, dinas-dinas terkait, dan pihak-pihak swasta yang ingin mengembangkannya.

\section{KONDISI UMUM}

\section{Letak, Luas, dan Batas Lokasi}

Taman Putroe Phang terletak di Jalan Tengku Sulaiman Daud, Gampong Neusu Jaya, Kecamatan Baiturrahman. Lokasi taman berada pada koordinat geografis $5^{\circ} 32^{\prime} 47.43 " \mathrm{LU}$ dan 95¹9'3.65"BT. Taman ini merupakan taman bersejarah peninggalan Kerajaan Aceh Darussalam yang termasuk ke dalam Benda Cagar Budaya (BCB). Luas area taman sekitar 2.42 Ha, dengan batas taman terdiri atas: 
Sebelah Utara : Jl. Sultan Alaiddin Mahmudsyah dan pengadilan tinggi

Sebelah Timur : Kompleks Rumah dinas Pangdam Iskandar Muda

Sebelah Selatan : Jl. Tengku Sulaiman Daud,Benda Cagar Budaya Gunongan

Sebelah Barat : Jl. Teuku Umar, Tower air PSSI

Lapangan Blang Padang terletak di Jl. Sultan Iskandar Muda, Kampung Baru, Kecamatan Baiturrahman. Secara geografis lapangan berada pada koordinat $5^{\circ} 33^{\prime} 0.37^{\prime \prime L U}$ dan $95^{\circ} 18^{\prime} 50.83$ "BT. Lapangan ini merupakan ruang terbuka hijau yang digunakan untuk berbagai kegiatan masyarakat dan pemerintah. Luas area lapangan sekitar 9.50 Ha. Batas lapangan terdiri atas:

Sebelah Utara : Jl. Prof.A.Majid Ibrahim II

Sebelah Timur : Jl. Sultan Iskandar Muda

Sebelah Selatan : J1. Sultan Iskandar Muda

Sebelah Barat : Jl. Bonjol

Hutan Kota BNI terletak di Jl. Laksamana Malahayati, Gampong Tibang, Kecamatan Syiah Kuala. Lokasi hutan kota berada pada koordinat $5^{\circ} 35^{\prime} 7.52^{\prime \prime} L U$ dan $95^{\circ} 21^{\prime} 0.55^{\prime \prime B T}$. Hutan kota dibangun sebagai hutan untuk menyumbang ruang terbuka hijau Kota Banda Aceh. Saat ini hutan kota memiliki luas 6.75 Ha. Pemerintăh terus berupaya untuk memperluas hingga mencapai $60 \mathrm{Ha}$. Batas hutan kota terdiri atas:

Sebelah Utara : Tambak ikan

Sebelah Timur : Kampus Universitas Ubudiyah Indonesia

Sebelah Selatan : Jl. Tengku Meulagu

Sebelah Barat : Tambak ikan

\section{Sejarah}

\section{Taman Putroe Phang}

Taman Putroe Phang merupakan situs sejarah bagian dari era kejayaan Kesultanan Aceh Darussalam. Taman Putroe Phang dibangun oleh Sultan Iskandar Muda (1639-1907) dan diperuntukkan bagi permaisurinya Putroe Phang, seorang putri dari Kerajaan Johor dan Kerajaan Pahang di semenanjung utara Melayu, Malaysia. Sebagaimana tradisi pada zaman dahulu, kerajaan yang kalah perang harus menyerahkan glodong pengareng-reng (Rampasan Perang), upeti, dan pajak tahunan. Termasuk juga menyerahkan putri kerajaan untuk dibawa sebagai tanda takluk. Putri kerajaan yang dibawa ini biasanya diperistri oleh raja dengan tujuan untuk mempererat tali persaudaraan dari kerajaan yang ditaklukkannya, sehingga kerajaan pemenang menjadi semakin besar dan semakin kuat kedudukannya.

Taman ini bersama beberapa situs sejarah lainnya di sepanjang Krueng Daroy merupakan bagian dari kompleks raksasa Istana Kesultanan Aceh Darussalam. Kitab Bustanus Salatin mencatat terdapat taman seluas 1000 depa (kurang lebih 1.5 $\mathrm{km}^{2}$ ) disebut Taman Ghairah yang berada di dalam lingkungan Istana Iskandar Muda. Bustanus Salatin juga menggambarkan banyak detail mengenai Taman Ghairah yang kini telah hilang. Dahulu di taman ini terdapat miniatur sungai, air terjun, pantai, balai, tebing, kolam, dan tanjung. Dari beberapa sumber sejarah yang ada, diketahui bahwa area Taman Ghairah pada masa kini mencakup Gunongan beserta Kandang Baginda (Makam Iskandar Tsani dan Sultanah Safiatuddin), 
keseluruhan Taman Putroe Phang dan area sekitarnya, sebagian Peucot Kerkhoff, Makam Sultan Iskandar Muda, Kandang Meuh, Kandang 12, Tamansari, dan Museum Tsunami juga termasuk ke dalam komplek kerajaan. Saat pasukan Belanda menyerang Koetaradja (Banda Aceh), sebagian besar kompleks istana hancur. Berbagai peninggalan sejarah kejayaan Kesultanan Aceh pun rusak akibat serangan tersebut. Di samping itu, seiring perjalanan waktu, sebagian tempat tersebut beralih fungsi sesuai tata wilayah yang ada. Menurut RTRW Kota Banda Aceh tahun 20092029, Taman Putro Phang termasuk ke dalam area pengembangan kota lama. Area ini banyak di temukan peninggalan sejarah Kesultanan Aceh dan kolonialisme.

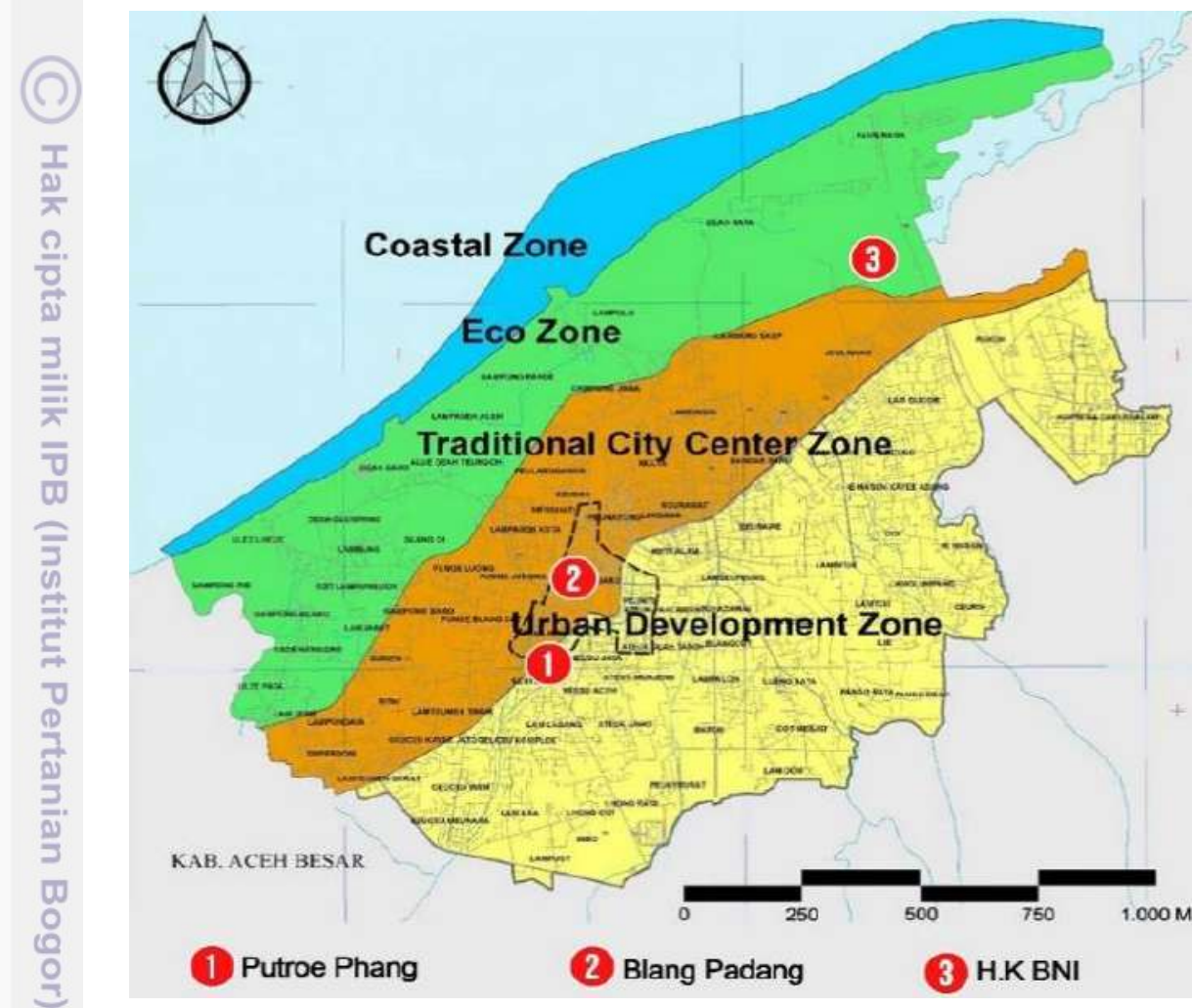

Gambar 9 Peta pembagian zona fisik Kota Banda Aceh

Pinto Khop yang terdapat di dalam taman juga telah terdaftar menjadi Benda Cagar Budaya. Taman ini telah mengalami beberapa kali renovasi akibat rusak terkena tsunami. Pada tahun 2009, Taman Putroe Phang mendapat bantuan renovasi dari CIDA (Canadian International Depelopment Agency) melalui CALGAP (Canada Aceh Local Government Assistance Program).

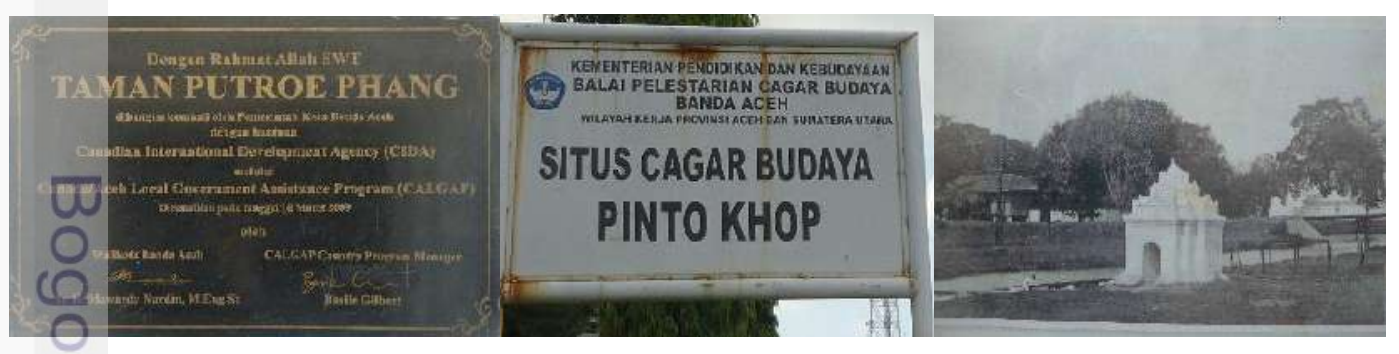

Gambar 10 Renovasi setelah tsunami kerja sama Pemkot dan CIDA (kiri), tercatat sebagai Benda Cagar Budaya (tengah), Pinto Khop pada masa penjajahan Belanda (kanan) 


\section{Lapangan Blang Padang}

Lapangan Blang Padang pada masa Kesultanan Aceh Darussalam merupakan I area persawahan yang luas yang diwakafkan kepada Masjid Raya Baiturrahman. 궁 Hasil dari pertanian lahan tersebut digunakan untuk menghidupi imam masjid yang pada saat itu tidak digaji. Ketika Belanda menguasai Koetaraja (Banda Aceh) pada tahun 1874, lahan yang sebelumnya sawah diuruk dan dijadikan sebagai lapangan untuk kegiatan-kegiatan masyarakat. Saat ini terjadi perselisihan antara Pemerintah Aceh dan TNI soal kepemilikan tanah tersebut. TNI mengaku tanah tersebut adalah aset milik TNI. Van Langen menulis beberapa pengalamannya selama di Aceh, di . antaranya "De Inrichting Van Het Atjehschee Staatbestur Onder Het Sultanaat" pada tahun 1888 yang kemudian diterjemahkan oleh Prof Abubakar Aceh dengan judul Susunan Pemerintahan Aceh semasa kesultanan. Dalam buku tersebut disebutkan bahwa Blang Padang dan Blang Punge adalah Umeung Musara (tanah - wakaf) Mesjid Raya Baiturrahman yang tidak boleh diperjualbelikan atau dijadikan harta warisan dan tidak ada pihak yang dapat menggangu gugat status keberadaan hak miliknya (Nivada 2011).

Tañoh meusarah digunakan sebagai sumber penghasilan Imam Mesjid Raya Baiturrahman. Jika penghasilan dari tanah wakaf masjid ini tidak cukup membiayai Masjid Ràya, maka dibantu oleh zakat padi atau barang barang lainnya dari penduduk yang berkediaman di sekitar masjid raya. Hasil tanah wakaf ini khusus untuk pe $\bar{m}$ eliharaan masjid, seperti keperluan muazin, bilal, khatib dan kebutuhan lainnya. Jika ada perbaikan berat maka diminta bantuan pada penduduk.

Belanda kembali melakukan invasi kedua pada 9 Desember 1873 dan 24 Januari 1874. Istana Kesultanan Aceh berhasil diduduki oleh Belanda setelah Sultan Alaidin Mahmudsyah (1870-1874M) meninggalkannya dan mengungsi ke Lueng Bata. Maka saat itu Letnan Jenderal Van Swieten mengumumkan pada dunia internasional bahwa Kesultanan Aceh, sesuai dengan hukum-perang (humaniter) menjadi hak milik Kolonial Belanda. Seluruh kekayaan pribadi dan aset istana dirampas dan dijadikan milik Kolonial Belanda sesuai dengan asas hukum Perang Reght van Over Winning (H.C. Zentgraaff 1981). Sisa peninggalan istana dan aset pribadi Sultan Aceh tersebut kemudian dikuasai oleh KNIL (Koninklijke Nederlands Indische Leger), seperti Kuta Alam, Neusu, Kraton, dan sejumlah aset lain yang sudah beralih fungsi saat ini.

Jadi, secara jelas dapat dikatakan bahwa serambi Masjid Raya Baiturrahman adalah Blang Padang yang sempat digunakan dahulu sebagai tempat berkumpul para hulubalang, prajurit, dan gajah yang mencapai 35 ribu pasukan. Lapangan ini juga sempat dijadikan arena MTQN tahun 1981 berganti nama menjadi Desah Arafah. Blang Padang pun sejak dulu telah menjadi tempat shalat Hari Raya Idul Fitri dan Idul Adha, tidak dilaksanakan di lapangan lain karena tanah tersebut adalah milik Masjid Raya Baiturrahman. Saat ini lapangan Blang Padang digunakan sebagai lapangan serbaguna dengan berbagai macam kegiatan, baik oleh pemerintah maupun masyarakat.

\section{Hutan Kota BNI}

Hutan Kota BNI dibangun pada tahun 2010 dengan Arsitek Agus R. Soeriaatmadja, dalam pembangunannya bekerja sama dengan Bank BNI, Yayasan Bustanussalatin, dan Pemerintah Kota Banda Aceh. Pembangunan hutan kota ini 
berawal dari gagasan Yayasan Bustanussalatin, LSM pemerhati lingkungan hidup, yang memberikan ide serta membuat konsep awal pengusulan hutan kota di Banda Aceh setelah tsunami 2004. Yayasan Bustanussalatin kemudian mengajukan usulan tersebut kepada Pemerintah Kota Banda Aceh dan menjalin kerja sama dengan pemerintah kota sebagai penyedia lahan dan PT. BNI 46 Persero sebagai penyandang dana melalui program CSR mereka yang sejalan dengan kegiatan pelestarian lingkungan, yaitu BNI Go Green. Pasca tsunami, lahan di daerah pantai utara Kota Banda Aceh ini disapu bersih oleh ombak besar Tsunami, vegetasi yang ada di lingkungan tersebut hilang terseret arus sehingga meninggalkan lahan kosong berawa yang tidak produktif. Pohon-pohon yang tersisa pun hanya beberapa dan tersebar acak tanpa meninggalkan penghijauan mengelompok layaknya yang diperlukan untuk pembangunan hutan kota. Foto udara di bawah ini memperlihatkan perubahan fungsi lahan sebelum dan sesudah menjadi hutan kota.

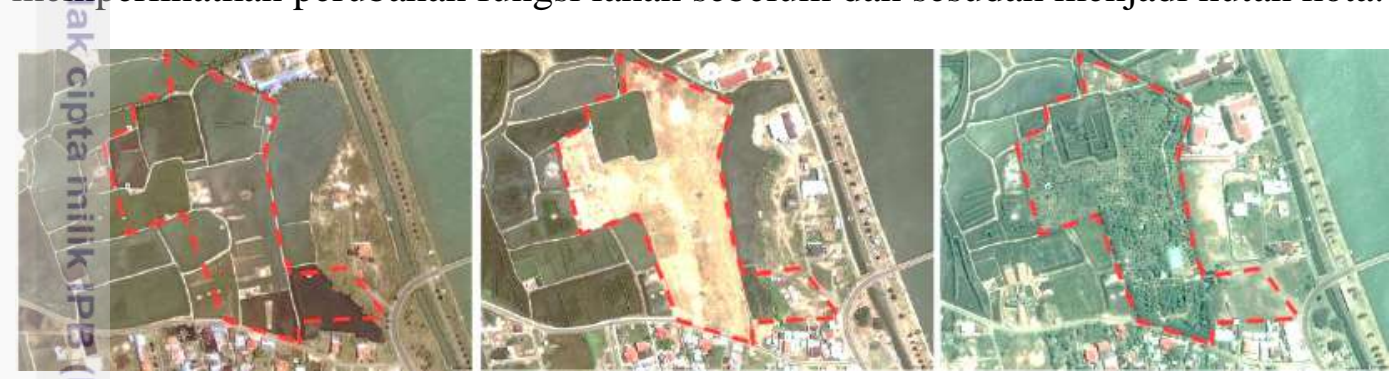

Gam̄ bar 11 Foto citra google earth, (kiri) sebelum dibangun tahun 2002, (tengah) ketika proses penimbunan tahun 2009, dan (kanan) sesudah dibangun tahun 2014

\section{Kondisi Fisik}

\section{Taman Putroe Phang}

Taman Putroe Phang adalah taman yang difungsikan sebagai ruang terbuka hijâ, tempat rekreasi, dan taman sejarah serta media pendidikan. Pengunjung yang dominan datang ke taman adalah pelajar tingkat dasar dan mahasiswa. Taman ini memiliki satu akses masuk melalui pintu utama dan di sekelilingnya terpagari oleh pagar besi. Di dalam taman terdapat fasilitas antara lain, parkiran, papan informasi, amphitheater, area playground, mushola, toilet, rumah pembibitan, dan bangku taman. Taman ini dikelola oleh Dinas Kebersihan dan Keindahan (DK3). TPP juga sering dipakai oleh pemerintah untuk kegiatan pameran dan bakti lingkungan, seperti komunitas-komunitas peduli lingkungan, promosi parawisata dan eventevent rakyat lainnya. Taman ini memiliki kesatuan dengan kompleks Benda Cagar Budaya Gunongan yang berjarak $30 \mathrm{~m}$ dari taman ini, namun karena terpisah oleh akses jalan raya yang membelah taman ini dengan Gunongan sehingga tidak terlihat adanya kesatuaan, padahal taman ini dan Gunongan merupakan bagian dari taman raja-raja.

Adapun yang menjadi ikon menarik di TPP adalah Bangunan Pinto Khop. Pintu ini menghadap ke istana dan pembuatan pintunya berkop, di atas kop itu dibentuk seperti biram berkelopak dan berkemuncakkan dari pada sangga pelinggam, terlalu gemerlap sinarya, berkelapan rupanya, bergelar pintu biram indera bangsa yang dapat diartikan dengan pintu mutiara keindraan atau kedewaan raja-raja, di dalam Kitab Busatanul Salatin disebut pula dengan dewala. Pintu Khop merupakan pintu penghubung antara istana dan Taman Putroe Phang. Selain itu, 


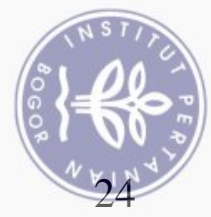

pintu gerbang berbentuk kubah ini merupakan tempat beristirahat putri setelah lelah berenang. Pintu ukir ini memiliki lebar $2 \mathrm{~m}$, panjang $2 \mathrm{~m}$, tinggi $3 \mathrm{~m}$, dan terletak tepat di tengah Sungai Darul Asyiki. Langit-langitnya atau rongga pintu berbentuk lengkungan busur dengan ukiran barat-timur. Sementara itu, ornamen-ornamen yang menghiasi bangunan berdiri sejak tahun 1400-an M yang lalu. Gambar di bawah ini menjelaskan beberapa fasilitas yang dapat ditemui di taman, seperti papan informasi, pos jaga/gerbang, area playground, dan Pinto Khop.

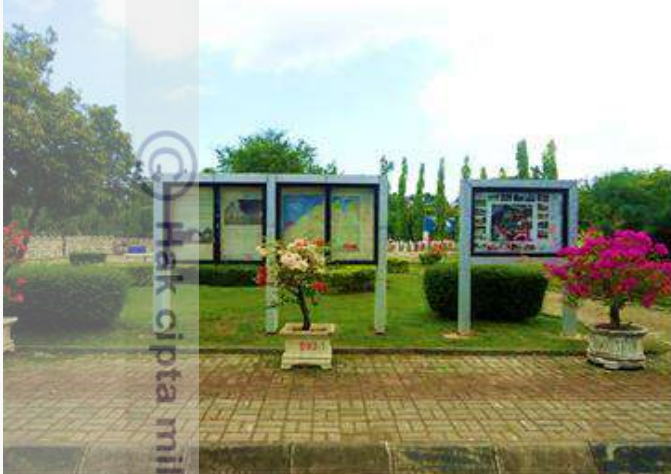

(a)

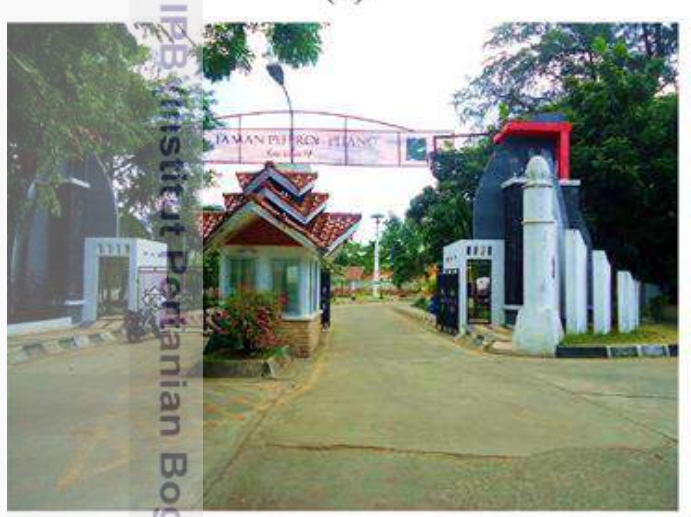

(c)

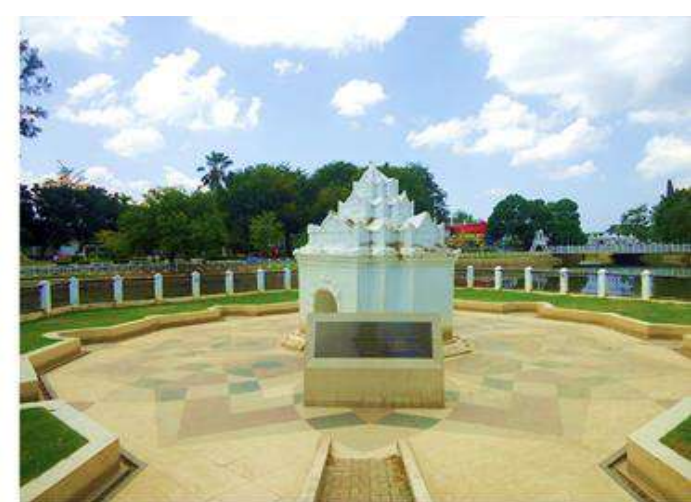

(b)

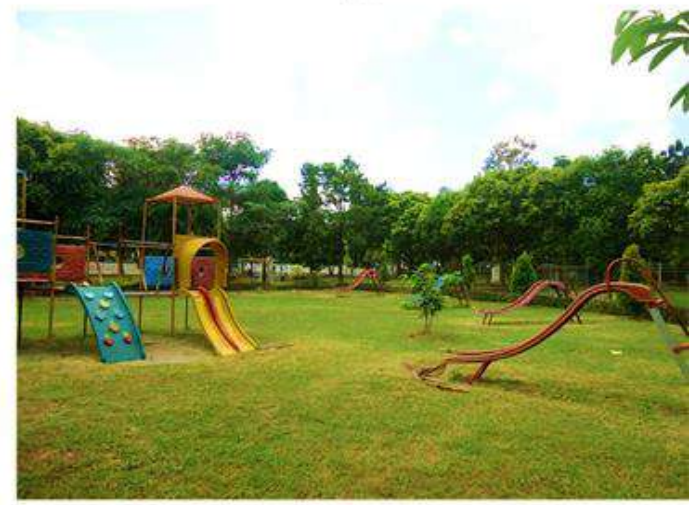

(d)

Gambar 12 Kondisi fisik T. Putroe Phang: (a) papan informasi, (b) pinto khop, (c) pintu masuk, dan (d) area playground

Tanaman hias dan pohon yang dapat ditemui di Taman Putroe Phang kurang lebih berjumlah 11 jenis tanaman hias, di antaranya adalah adam hawa, agave, asoka, bayam merah, pangkas kuning, seulanga, balik angina, dan tombak raja. Sedangkan untuk pohon di antaranya adalah angsana, ara, asam jawa, beringin, cemara laut, dadap kuning, inai, johar, kelapa, kemuning, mahoni, mane, mangga, nangka, palem ekor tupai, dan tanjung.

\section{Lapangan Blang Padang}

Lapangan Blang Padang terletak di tengah-tengah kota. Lapangan ini berjarak tidak jauh dari Masjid Raya Baiturrahman. Lapangan ini digunakan untuk berbagai kegiatan masyarakat, mulai dari aktivitas olahraga, sholat ied, upacara, zikir, konser, pameran, dan event-event lainnya. Setiap hari lapangan ini lebih dominan digunakan untuk olahraga saat pagi dan sore hari. Vegetasi yang terdapat pada lapangan-didominasi oleh pohon-pohon penaung, pengarah, dan beberapa jenis pohon penghasil buah. Vegetasi ditanam membentuk border dan naungan pada 
sekeliling dan bagian jalan. Sementara itu, vegetasi pada area tengah hanya berupa rumput yang digunakan untuk upacara hari-hari nasional. Terdapat beberapa fasilitas olahraga seperti jalur jogging, lapangan sepak bola, lapangan basket, lapangan futsal, lapangan voli, toilet, mushola, monumen pesawat RI-001, monumen Aceh thanks to the world, monumen terima kasih Republik Rakyat China, plakat terima kasih kepada 53 negara yang membantu Aceh setelah tsunami, dan beberapa monumen lainnya. Fasilitas-fasilitas tersebut terlihat tidak terpelihara dengan baik dan ada beberapa signage yang telah rusak.

Lapangan Blang Padang masih memiliki banyak kekurangan seperti tidak adanya area parkir, pedagang kaki lima yang berjualan di dalam lapangan, hingga sampah. Dari segi pemeliharaan, lapangan ini masih banyak kekurangan, masih ada sengketa kepemilikan lahan antara pemerintah dan TNI, sehingga dalam pengembangan dan pengelolaannya masih banyak kekurangan.

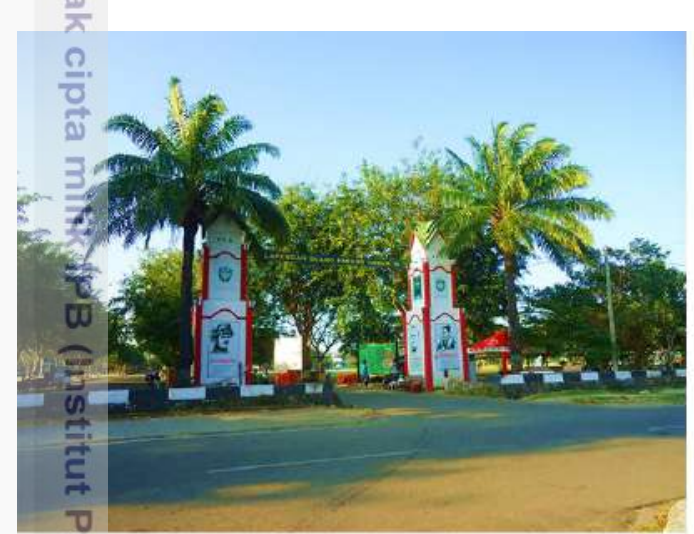

(a)

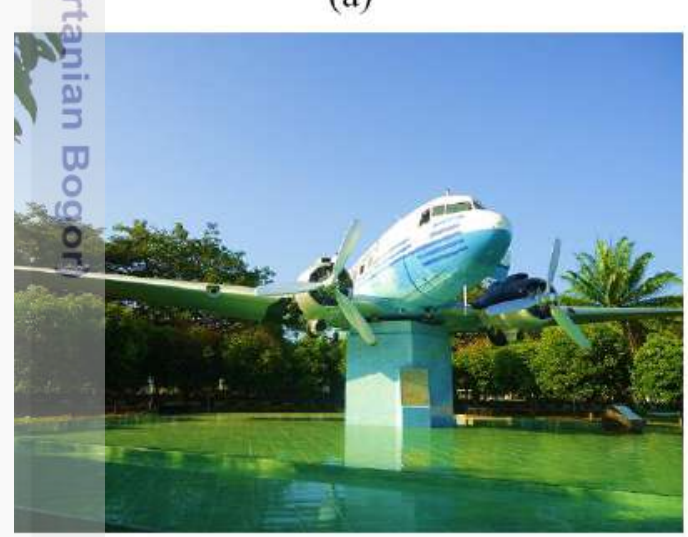

(c)

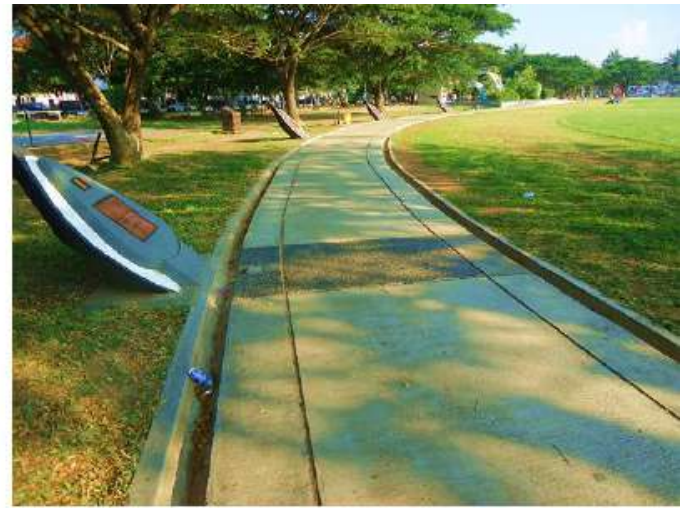

(b)

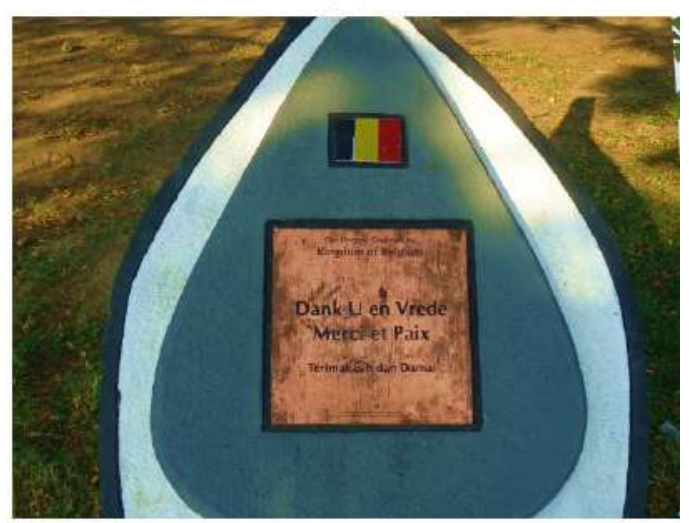

(d)

Gambar 13 Kondisi fisik Lapangan Blang Padang: (a) gerbang masuk, (b) jogging track, (c) monumen Pesawat RI-01, dan (d) monumen terima kasih dan damai dari 53 negara

\section{Hutan Kota BNI}

Hutan Kota BNI terletak di Tibang, dibangun di atas lahan yang terlantar akibat tsunami yang difungsikan sebagai hutan dengan fungsi ekologi dan dapat dimanfaatkan oleh masyarakat. Masyarakat sekitarnya juga turut terlibat dalam mengelola dan memanfaatkan hutan ini. Hutan Kota BNI juga menjadi tempat penelitian tanaman, satwa, sosial dari peneliti yang ada di sekitar Kota Banda Aceh. Fasilitas yang terdapat di antaranya papan informasi, plaza, jalur pejalan kaki di 


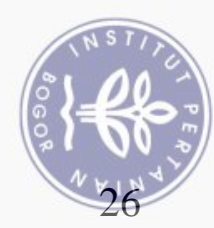

sepanjang route track, jembatan pengamatan burung (ramp canopy trail), deck, taman bermain dan taman anak tradisional, lapangan olahraga, parkir, mushola, toilet, serta jembatan sekaligus pintu gerbang masuk secara simbolis Hutan Kota I BNI Tibang. Fasilitas jalur deck yang ditemui saat ini banyak terdapat coretancoretan vandalisme pengunjung. Pengelola harus membuat program-program untuk mengurangi tindakan vandal tersebut, kesadaran pengunjung akan fasilitas umum sangat penting melalui program edukasi, hukuman tegas terhadap pengunjung yang merusak fasilitas hutan. Koleksi tanaman yang terdapat di dalamnya didominasi oleh pohon-pohon dengan jarak tanam $4 \mathrm{~m}$. Saat ini pohon yang telah ditanam tingginya sekitar 1-10 m. Kanopi dari pohon-pohon tersebut belum menutup dengan - sempurna. Pertumbuhan pohon kurang baik karena kondisi tanah bukan top soil, melainkan tanah uruk serta lokasi tidak terlalu jauh dari pantai membuat sebagian vegetasi membutuhkan banyak air. Penyiraman tanaman dilakukan secara manual dengan afat selang yang terhubung dengan beberapa sumur bor yang sengaja dibuat untuk kesediaan air (Gambar 14).

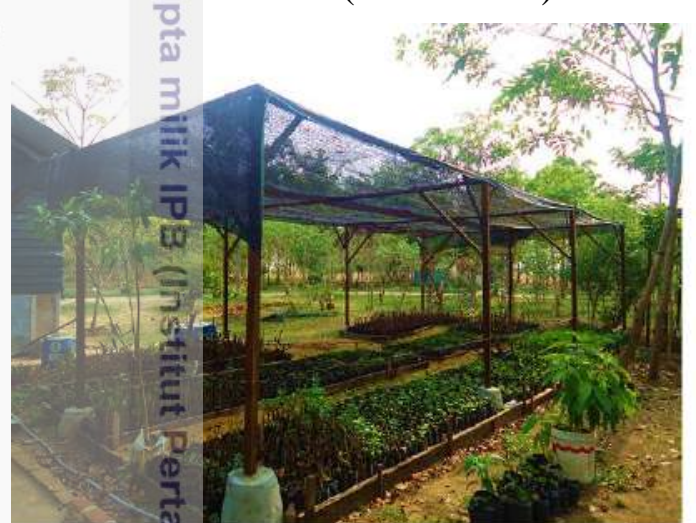

(a)

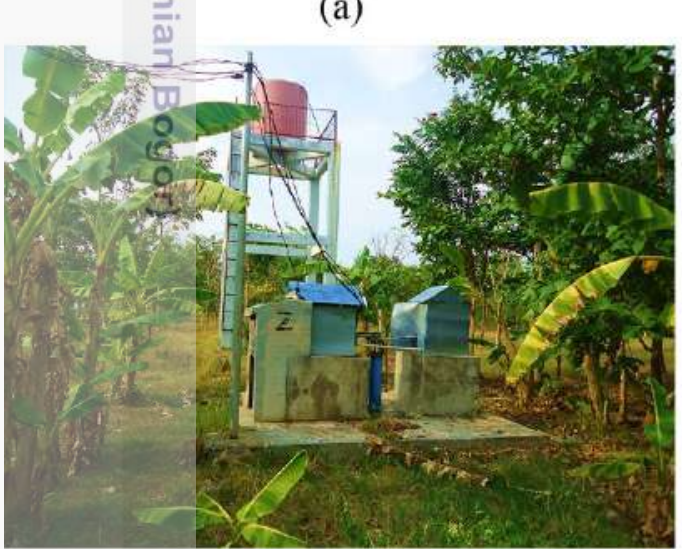

(c)

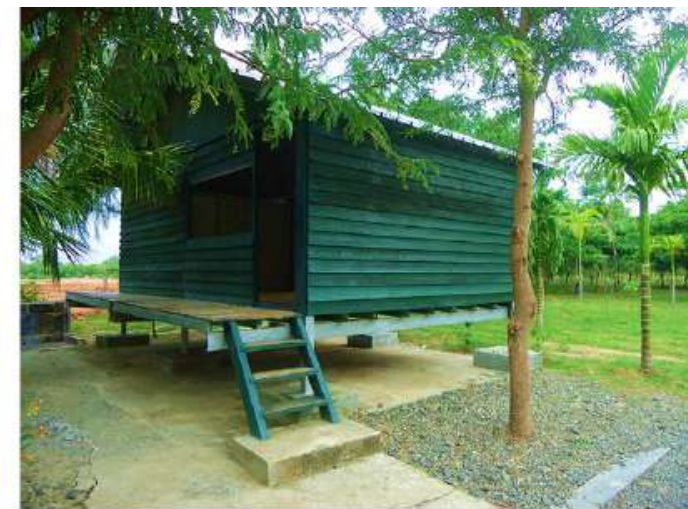

(b)

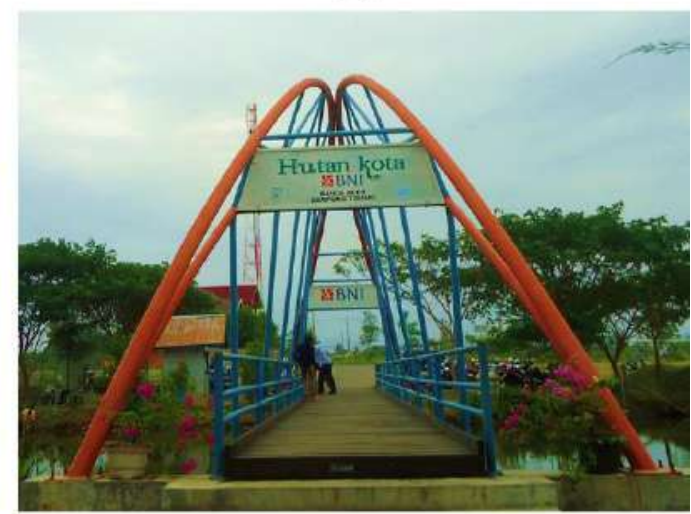

(d)

Gambar 14 Kondisi fisik Hutan Kota BNI Tibang: (a) pembibitan pohon, (b) mushola, (c) sumur untuk penyiraman, dan (d) gerbang masuk

Selain fungsi di atas, hutan kota juga berfungsi sebagai tempat pembibitan. Tanaman tersebut nantinya akan ditanam pada area yang masih kosong. Sebagian pohon yang ditanam di dalamnya merupakan pemberian dari walikota seluruh Indonesia dan ditanam oleh walikota tersebut. Pada bagian welcome area terdapat pohon yang ditanam oleh rombongan presiden dan ibu negara era pemerintahan Susilo Bambang Yudhoyono saat ke Aceh pada tahun 2010. Saat ini, hutan kota tersebut menjadi hutan kota terbesar yang terdapat di Kota Banda Aceh. 


\section{HASIL DAN PEMBAHASAN}

\section{Sebaran Ruang Terbuka Hijau Kota Banda Aceh}

Luas dan sebaran RTH di Kota Banda Aceh tahun 2013 berdasarkan data survei Dinas Kebersihan dan Keindahan adalah sebagai berikut

Tabel 6 Bentuk dan luasan RTH Kota Banda Aceh

\begin{tabular}{clcc}
\hline No. & \multicolumn{1}{c}{ Komponen RTH } & Luas Area (Ha) & Persentase RTH (\%) \\
\hline 1 & Taman Kota & 49.45 & 7.40 \\
2 & Hutan Kota & 28.60 & 4.30 \\
$3 \bar{T}$ & Lapangan Olahraga & 20.35 & 3.00 \\
4 & Jalur Hijau Jalan & 548.00 & 81.90 \\
50 & Makam & 7.98 & 1.20 \\
6 & RTH Sungai/Waduk/Boezem & 14.57 & 2.20 \\
\hline & \multicolumn{1}{c}{ Luas Total RTH } & 668.95 & 100.00 \\
\hline
\end{tabular}

(Sumber: Dinas Kebersihan dan Keindahan Kota Banda Aceh)

RTH publik di Kota Banda Aceh yang paling luas berbentuk jalur hijau jalan, luaşnya $5.48 \mathrm{~km}^{2}$, sedangkan RTH publik yang mempunyai luas paling kecil adalah pemakaman dengan luas $0.08 \mathrm{~km}^{2}$. Jalur hijau jalan tersebar sepanjang jalan koridor utama di Kota Banda Aceh, dan ada pula yang berbentuk pulau-pulau jalan yang terisi oleh tanaman-tanaman penutup tanah, semak, display, maupun tanaman berbunga. Pohon yang dipakai sebagai jalur hijau dominan oleh trembesi, angsana, mah̆oni, glodogan tiang, glodogan bulat, tanjung, cemara laut, dan kerai payung.

J Taman pemakaman yang terdapat di Banda Aceh antara lain Taman Makam Pahlawan, TPU Labui, TPU Mulia, TPU Keudah, TPU Darussalam, TPU Kota Baru, TPU Suka Damai, TPU Lamtemen, TPU Bitai, TPU Gampong Pande, TPU Cot Masjid, TPU Pante Riek, TPU Desa Lamsie Daya, dan Perkuburan massal korban tsunami di kawasan Ulee Lheue.

Taman kota eksisting saat ini antara lain adalah Taman Sari Kids Rock, Taman Edukasi Tsunami, Taman Nursery Baitussalatin, Taman Bermain Ulee Lheue, Taman Lambung, Taman Pantai Cermin, Taman Tugu Adipura, Taman Trembesi, Lapangan Neusu, dan Taman Ratu Safiatuddin. Total luas RTH dari hasil perhitungan DK3 adalah sebesar $6.88 \mathrm{~km}^{2}$. Dengan demikian, Kota Banda Aceh saat ini telah memiliki RTH publik sebesar $\pm 12 \%$ dari luas total wilayah Kota Banda Aceh yaitu $61.36 \mathrm{~km}^{2}$. Gambar contoh RTH publik yang berada di Kota Banda Aceh disajikan pada Gambar 15.

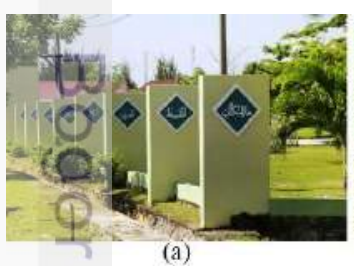

(a)

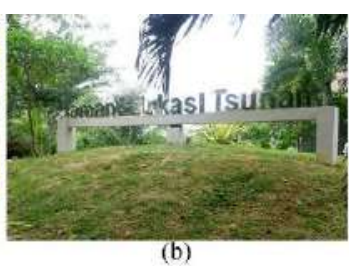

(b)

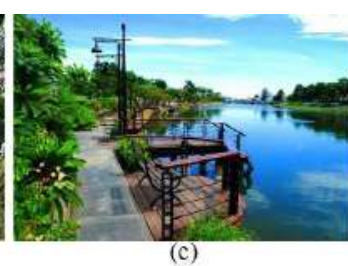

(c)

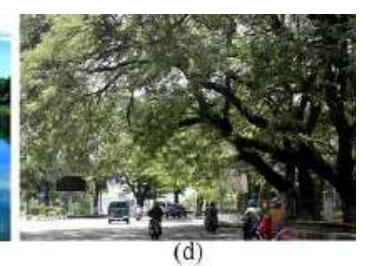

(d)

Gambar 15 Kondisi eksisting RTH (a) kuburan masal tsunami (b) taman edukasi tsunami (c) simpadan Krueng Aceh (d) jalur hijau Pendopo Gubernur 


\section{Indentifikasi Jenis dan Fungsi Tanaman}

Vegetasi yang terdapat pada ketiga lokasi penelitian merupakan vegetasi yang Th hidup di dataran rendah. Secara umum, vegetasi pada lokasi penelitian diidentifikasi berdasarkan spesies tanaman, pola penanaman, dan fungsi tanaman. Berikut adalah jenis dan jumlah vegetasi dari ketiga lokasi penelitian tersebut.

Tabel 7 Sebaran vegetasi di tiga lokasi penelitian

\begin{tabular}{lcc}
\hline \multicolumn{1}{c}{ Lokasi } & Jenis Vegetasi & Jumlah Vegetasi \\
\hline Taman Putroe Phang & 63 & 1256 \\
Lapangan Blang Padang & 15 & 744 \\
Hutan Kota BNI & 75 & 1915 \\
\hline
\end{tabular}

\section{Taman Putroe Phang}

Taman Putroe Phang telah mengalami beberapa kali pergantian jenis vegetasi. Tanaman yang digunakan saat masa kesultanan Aceh adalah tanaman berbunga dan berbuah. Berdasarkan hasil penelitian Soeriaatmadja (2008) dalam bukunya yang berjudul "Khasanah Tanaman Bunga dan Buah Taman Raja-raja Bustanussalatin Aceh", teridentifikasi sekitar 111 jenis vegetasi. Walau demikian, vegetasi saat ini sudah banyak mengalami perubahan. Perubahan paling besar terjadi ketika komplekskesultanan terbakar pada tahun 1874. Semua vegetasi musnah dan hanya tersisa satu buah elemen keras berupa signage yaitu Pinto khop. Tanaman yang ada saat ini sebagian besar ditanam kembali setelah bencana tsunami. Ketika bencana terjadi, taman ini rusak parah dan menyisihkan beberapa vegetasi saja. Berdasarkan hasil pengamatan lapang dan hasil inventarisasi dari Dinas Kebersihan dan Keindahan Kota Banda Aceh, vegetasi di Taman Putroe Phang berjumlah \pm 63 spesies. Area penerimaan (welcome area) didominasi oleh jenis tanaman pengarah dan tanaman semak. Area penyambutan dan sekitar papan informasi didominasi oleh vegetasi penutup tanah berupa rumput Zoysia matrella dan semak yang terdiri atas tanaman teh-tehan dan bugenvil. Area di sekeliling sungai ditanami oleh pohon pengarah berupa glodogan tiang (Polyalthia longifolia). Bagian utara dari Taman Putroe Phang didominasi oleh pohon besar dan pohon sedang yang ditanam secara acak yang berfungsi sebagai vegetasi penaung. Pohon-pohon tersebut terdiri atas tanjung (Mimusops elengi), mahoni (Swietenia mahagoni), damar (Agathis dammara), trembesi (Samanea saman), dan angsana (Pterocarpus indicus). Jenis dan jumlah vegetasi pada Taman Putroe Phang disajikan pada Tabel 8.

Tabel 8 Jenis dan fungsi vegetasi pada Taman Putroe Phang

\begin{tabular}{lllcl}
\hline No. & Nama Lokal & \multicolumn{1}{c}{ Nama Latin } & Jumlah & \multicolumn{1}{c}{ Fungsi } \\
\hline 1 & Adam hawa & $\begin{array}{l}\text { Tradescantia spathacea } \\
\text { Variegata }\end{array}$ & 115 & Groundcover \\
2 & Agave & Agave macrocantha variegate & 7 & $\begin{array}{l}\text { Display, Point of interest } \\
\text { Acacia mangium }\end{array}$ \\
3 & Akasia & 1 & $\begin{array}{l}\text { Point of interest, } \\
\text { peneduh }\end{array}$ \\
4 & Angsana & Pterocarpus indicus & 5 & Peneduh \\
5 & Ara & Ficus racemose & 1 & Peneduh \\
6 & Asam jawa & Tamarindus indica & 20 & Peneduh \\
7 & Batik angin & Excoecaria cochinchinensis & 1 & Display plant \\
\hline
\end{tabular}


Tabel 8 Jenis dan fungsi vegetasi pada Taman Putroe Phang (lanjutan)

\begin{tabular}{|c|c|c|c|c|}
\hline No. & Nama Lokal & Nama Latin & Jumlah & Fungsi \\
\hline 8 & Bayam merah & Pseuderanthemum jessdica & 100 & Display plant \\
\hline 9 & Bayur & Pterospermum javanicum & 8 & Peneduh \\
\hline 10 & Beringin & Ficus benjamina & 6 & $\begin{array}{l}\text { Point of interest, } \\
\text { peneduh }\end{array}$ \\
\hline 11 & Biola cantik & Ficus lyrata & 2 & $\begin{array}{l}\text { Point of interest, } \\
\text { peneduh }\end{array}$ \\
\hline 12 & Bugenvil & Bougainvillea sp. & 6 & Display plant \\
\hline 13 & Bunga merak & Caesalpinia pulcherrima & 9 & Pembatas \\
\hline 14 & Bungur & Langerstromela speclosa & 9 & $\begin{array}{l}\text { Tanaman tepi jalan, } \\
\text { point of interest, } \\
\text { peneduh }\end{array}$ \\
\hline & Cemara laut & Casuarina equisetifolia & 5 & Screen, border \\
\hline $16 \frac{\mathrm{T}}{\frac{\mathrm{O}}{\pi}}$ & Dadap merah & Erythrina crista-galli & 3 & $\begin{array}{l}\text { Peneduh, penyemarak } \\
\text { taman }\end{array}$ \\
\hline $17 \underline{\underline{n}}$ & Damar & Agathis dammara & 2 & point of interest \\
\hline $18 \div$ & Gaharu & Aquilaria moluccensis & 8 & Peneduh \\
\hline $19 \Xi$ & Glodogan bulat & Polyalthia fragans & 5 & Pembatas \\
\hline 20 三 & Glodogan tiang & Polyalthia longifolia & 36 & $\begin{array}{l}\text { Pengarah jalan, } \\
\text { penghalang tabir }\end{array}$ \\
\hline $21_{\varpi}^{\varpi}$ & Hanjuang & Cordiline sp. & 105 & Display plant \\
\hline $22=$ & Inai & Lawsonia inermis & 2 & Display plant \\
\hline $23 \omega$ & Johar & Cassia siamea & 1 & Peneduh \\
\hline $24 \bar{E}$ & Kelapa & Cocus nucifera & 1 & Point of interest \\
\hline $25_{\tau}^{r+}$ & Kelumpang jari & Sterculia foetida & 1 & Peneduh \\
\hline $26 \frac{1}{7}$ & Kemuning & Murraya paniculata & 1 & Display plant \\
\hline $27 \stackrel{0}{\frac{0}{3}}$ & Kenanga & Cananga odorata & 8 & $\begin{array}{l}\text { tanaman pelindung, } \\
\text { penetralisir bau }\end{array}$ \\
\hline $28^{3}$ & Kersen & Muntingia calabura & 3 & peneduh \\
\hline 290 & Ketapang & Terminalia catappa & 5 & $\begin{array}{l}\text { point of interest, } \\
\text { peneduh }\end{array}$ \\
\hline $30=$ & Kirai payung & Filicium decipiens Thw. & 5 & Peneduh \\
\hline 31 & Kol banda & Pisonia alba & 1 & Display plant \\
\hline 32 & Kayu manis & Cinnamomun burmannii & 8 & Peneduh \\
\hline 33 & Laban & Vitex pinnata & 15 & Peneduh \\
\hline 34 & Mahkota dewa & Phaleria macrocarpa & 8 & $\begin{array}{l}\text { Penyemarak taman, } \\
\text { tanaman tabir }\end{array}$ \\
\hline 35 & Mahoni & Swietenia mahagoni & 22 & Peneduh \\
\hline 36 & Mangga & Mangifera indica & 6 & Peneduh \\
\hline 37 & Matoa & Pometia pinnata & 4 & Display plant \\
\hline 38 & Melinjo & Gnetum gnemon & 9 & Peneduh \\
\hline 39 & Meranti merah & Shorea sp. & 1 & Peneduh \\
\hline 400 & Nangka & Artocarpus heterophyllus & 1 & Peneduh \\
\hline 41 & Nira & Arenga pinnata & 3 & Peneduh \\
\hline 42 & Pala & Myristica fragans & 4 & Peneduh \\
\hline 43 & Palem ekor tupai & Wodyetia bifurcata & 3 & point of interest \\
\hline 44 & Palem kuning & Chrysalidocarpus lutescens & 10 & Pengarah \\
\hline 45 & Palem putri & Veitchia merrili & 6 & Pengarah, display \\
\hline
\end{tabular}




\begin{tabular}{|c|c|c|c|c|}
\hline No. & Nama Lokal & Nama Latin & Jumlah & Fungsi \\
\hline 46 & Palem sabai & Sabai palmetto & 1 & Pengarah \\
\hline 47 & Pangkas kuning & Duranta erecta Gold & 106 & Formal, Display \\
\hline 48 & Pasak bumi & Eurycoma longifolia & 8 & Display plant \\
\hline 49 & Pinang & Areca catechu & 21 & Point of interest \\
\hline 50 & $\begin{array}{l}\text { Pohon kupu- } \\
\text { kupu }\end{array}$ & Bauhinia blakeana & 3 & $\begin{array}{l}\text { Point of interest, } \\
\text { peneduh }\end{array}$ \\
\hline 51 & Pulai & Alstonia sp. & 21 & Peneduh \\
\hline 52 & Rumput manila & Zoysia matrella & $456 \mathrm{~m}^{2}$ & Penutup tanah \\
\hline 53 & Sentang & Melia excelsa jack & 2 & Peneduh \\
\hline 54 & Sirsak & Annaona muricata & 1 & Peneduh \\
\hline 55 & Soka & Ixora javanica & 17 & Display, screen \\
\hline 56 & Srikaya & Anona squamosal & 1 & Peneduh \\
\hline 57 & Suren & Toona sureni & 10 & Peneduh \\
\hline 58 & Tanjung & Mimusops elengi & 101 & Peneduh \\
\hline 59 & Teh-tehan & Acalypha siamensis & $30 \mathrm{~m}^{2}$ & $\begin{array}{l}\text { tanaman pangkas } \\
\text { (topiary), point of } \\
\text { interest, border }\end{array}$ \\
\hline 60 & Terompet biru & Ruellia brittoniana & 275 & Display, groundcover \\
\hline 61 & Tombak raja & Yисса sp. & 2 & point of interest \\
\hline 62 & Trembesi & Samanea saman & 5 & Peneduh \\
\hline 63 & Tri Colour & $\begin{array}{l}\text { Dracaena marginata var } \\
\text { Tricolor }\end{array}$ & 100 & Estetika \\
\hline
\end{tabular}

(sumber: Data inventarisasi Dinas Kebersihan dan Keindahan 2012 dan survei lapang)

\section{Lapangan Blang Padang}

Lapangan Blang Padang atau yang disebut pula sebagai alun-alun Kota Banda Aceh merupakan lapangan yang digunakan masyarakat untuk melakukan berbagai macam aktivitas, seperti olahraga, rekreasi, pameran, sholat Idul Fitri, upacara, dan zikir akbar. Lapangan Blang Padang memiliki vegetasi dominan berupa vegetasi penutup tanah yaitu rumput Zoysia matrella yang bercampur dengan rumput liar berupa rumput embun. Jenis pohon didominasi oleh pohon yang berfungsi sebagai vegetasi pengarah dan penaung. Sebelum bencana tsunami tahun 2004, di lapangan ini terdapat banyak pohon asam jawa (Tamarindus indica) yang berukuran besar. Ketika tsunami menerjang hanya menyisakan beberapa saja. Lapangan ini terbagi menjadi dua bagian yang dipisahkan oleh jalan yang melintang di tengahnya.

Vegetasi Pohon pada Lapangan Blang Padang ditanam di sepanjang area sirkulasi dan di sekeliling area lapangan yang ditanam dengan pola memanjang yang berfungsi sebagai pengarah serta penaung pada beberapa area, seperti pada jalur masuk, area bermain anak, dan jogging track. Pohon penaung didominasi oleh pohon ki hujan (Samanea saman), angsana (Pterocarpus indicus), dan mahoni (Swietenia mahagoni).

Tabel 9Jenis dan fungsi vegetasi pada Lapangan Blang Padang

\begin{tabular}{lllll}
\hline No & \multicolumn{1}{c}{ Nama Lokal } & \multicolumn{1}{c}{ Nama Latin } & Jumlah & \multicolumn{1}{c}{ Fungsi } \\
\hline 1 & Agave & Agave sp. & 32 & Estetika \\
2 & Angsana & Pterocarpus indicus & 45 & Peneduh, pengarah \\
3 & Asam jawa & Tamarindus indica & 43 & Peneduh \\
\hline
\end{tabular}


Tabel 9 Jenis dan fungsi vegetasi pada Lapangan Blang Padang (lanjutan)

\begin{tabular}{|c|c|c|c|c|}
\hline No & Nama Lokal & Nama Latin & Jumlah & Fungsi \\
\hline 4 & Glodogan tiang & Polyalthia longifolia & 9 & Pengarah \\
\hline 5 & Hanjuang & Cordyline sp. & 230 & Display \\
\hline 6 & Kelapa & Cocus nucifera & 5 & Pengarah \\
\hline 7 & Kelapa sawit & Elaeis guineensis & 45 & Pengarah, Screen \\
\hline 8 & Ki hujan & Samanea saman & 106 & Peneduh, pengarah \\
\hline 9 & Mahoni & Swietenia mahagoni & 57 & Peneduh, pengarah \\
\hline & Mangga & Mangifera indica & 30 & Peneduh \\
\hline 11 & Merak kuning & Caesalpinia pulcherrima & 1 & Peneduh, estetika \\
\hline 12 & Palm ekor tupai & Wodyetia bifurcata & 11 & Pengarah, Screen \\
\hline 13 & Pucuk merah & Syzygium oleina & 7 & Display \\
\hline 14 & Rumput manila & Zoysia matrella & $0,78 \mathrm{~km}^{2}$ & Penutup tanah \\
\hline & @Sawo & Manilkara zapota & 8 & Peneduh \\
\hline & Tanjung & Mimusoph elengi & 120 & Peneduh \\
\hline 17 & उTeh -tehan & Acalypha macrophylla & $0,02 \mathrm{~km}^{2}$ & Border \\
\hline
\end{tabular}

(sumber: Survei lapang)

\section{Hutan Kota BNI}

Karakteristik vegetasi yang terdapat di Hutan Kota BNI didominasi oleh pohon dataran rendah dan vegetasi formasi pantai/formasi barringtonia yang terdiri atas pohon rendah, sedang, dan tinggi. Pohon-pohon tersebut ditanam menggunakan pola grid berupa blok-blok tanaman yang mempunyai jenis sama dengan jarak tanam $4 \mathrm{~m}$, seperti blok vegetasi ki hujan (Samanea saman) yang ditanam oleh Presiden Susilo Bambang Yudhoyono, para menteri, dan wali kota seIndonesia saat berkunjung ke Aceh dan berbagai blok tanaman hasil dari pemberian seluruh wali kota se-Indonesia yang berupa tanaman khas daerahnya masingmasing, serta blok vegetasi riparian dan mangrove. Area di sekeliling Hutan Kota BNI ditanami pohon cemara laut (Casuarina equisetifolia) yang disusun sejajar sebägai vegetasi border. Walau demikian, saat pengamatan, pola penanaman grid seperti yang dijelaskan sebelumnya ternyata tidak terlihat secara menyeluruh pada semua area yang terdapat di hutan kota. Sebagian hutan kota ditanami oleh vegetasi dengan pola yang tidak beraturan. Begitu pula pada area yang baru ditanami tidak mempunyai pola yang konsisten. Selain itu, tanaman pada Hutan Kota BNI tidak semuanya dapat tumbuh dengan baik. Hal tersebut disebabkan oleh kondisi tanah yang tidak memiliki top soil karena area ini sebelumnya merupakan lahan bekas tambak yang diuruk.

Tabel 10 Jenis dan fungsi vegetasi pada Hutan Kota BNI

\begin{tabular}{lllcc}
\hline No & \multicolumn{1}{c}{ Nama Lokal } & \multicolumn{1}{c}{ Nama Latin } & Jumlah & Fungsi \\
\hline 100 Akasia & Acacia longifolia & 13 & Peneduh \\
$2 \bigcirc$ & Angsana & Pterocarpus indicus & 82 & Peneduh \\
$3 \bigcirc$ & Asam jawa & Tamarindus indica & 40 & Peneduh \\
4 & Bakau hitam & Rhizopora mucronata & 45 & Border, Screen \\
5 & Bambu & Melocanna bambusoides & 24 & Border, Pengarah \\
6 & Bambu kuning & Phyllostachys sulphrurea & 1 & Estetika \\
\hline
\end{tabular}




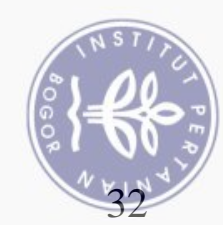

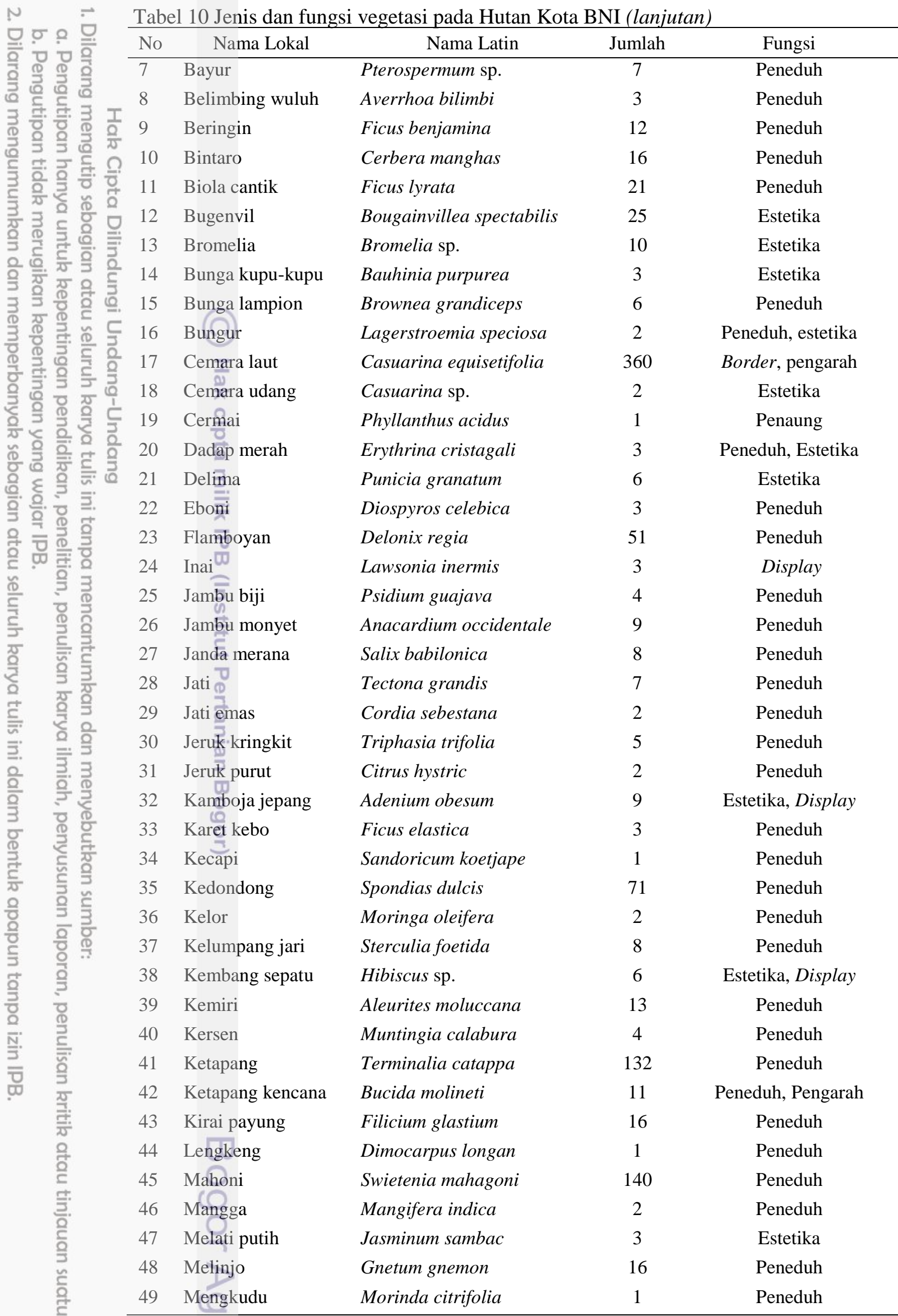


Tabel 10 Jenis dan fungsi vegetasi pada Hutan Kota BNI (lanjutan)

\begin{tabular}{|c|c|c|c|c|}
\hline No & Nama Lokal & Nama Latin & Jumlah & Fungsi \\
\hline 50 & Merak kuning & Caesalpinia pulcherrima & 8 & Pengarah, Display \\
\hline 51 & Merak merah & Caesalpinia pulcherrima & 12 & Pengarah, Display \\
\hline 52 & Mimba & Azadirachta indica & 50 & Peneduh \\
\hline 53 & Moja & Aegle marmelos & 1 & Peneduh \\
\hline 54 & Nangka & Artocarpus heterophyllus & 6 & Peneduh \\
\hline 55 & Nona srikaya & Annona squamosa & 25 & Peneduh \\
\hline 56 & Nyamplung & Calophyllum inophyllum & 55 & Border \\
\hline 57 & Pandan & Pandanus amaryllifolius & 8 & Display \\
\hline 58 & Pinang & Areca catechu & 11 & Pengarah \\
\hline 59 & Pisang & Musa sp. & 2 & Screen \\
\hline 60工 & Pisang hias & Heliconia sp. & 32 & Display, Estetika \\
\hline $61 \frac{01 \pi}{\pi}$ & Pohon kelapa & Cocos nucifera & 10 & Peneduh \\
\hline 62 음 & Pucuk merah & Syzygium oleina & 6 & Display, Estetika \\
\hline 63 गे & Pulai & Alstonia scholaris & 5 & Peneduh \\
\hline $64 \Xi$ & Roda & Hura crepitans & 13 & Peneduh \\
\hline $65 \overline{\bar{\lambda}}$ & Sawo & Manilkara zapota & 44 & Peneduh \\
\hline $66 \overline{\overline{0}}$ & Sengon & Paraseruanthes falcataria & 2 & Peneduh \\
\hline $67^{\text {Ш }}$ & Sentang & Azadirachta excelsa & 4 & Peneduh \\
\hline $68 \overline{7}$ & Sentul & Sandoricum koetjape & 5 & Peneduh \\
\hline $69=$ & Waru & Hibiscus tiliaceus, & 5 & Peneduh \\
\hline $70 \stackrel{ᄃ}{=}$ & Sirsak & Annona muricata $L$ & 3 & Peneduh \\
\hline $71 ळ$ & Soka & Ixora sp. & 1 & Display \\
\hline 72 वे & Spatodea & Spathodea campanulata & 24 & Peneduh \\
\hline $74 \frac{3}{2}$ & Sukun & Artocartus altilis & 9 & Peneduh \\
\hline $75^{\sqsupset}$ & Tanjung & Mimusoph elengi & 34 & Pengarah, Peneduh \\
\hline 760 & Trembesi & Samanea saman & 347 & Peneduh \\
\hline $77 \%$ & Turi & Sesbania grandiflora & 3 & Peneduh \\
\hline
\end{tabular}

(sumber: Data inventarisasi Dinas Kebersihan dan Keindahan 2015)

\section{Evaluasi Kenyamanan Termal}

\section{Analisis Taman Kota Terhadap Suhu Udara}

Analisis taman kota terhadap suhu udara merupakan penilaian keberadaan taman kota dalam memengaruhi suhu udara, baik di dalam maupun di sekitar taman penelitian. Secara umum, analisis ini dilakukan melalui dua tahap, yakni analisis suhu udara dari aspek waktu pengukuran dan aspek area pengukuran. Pengamatan suhu udara dari aspek waktu pengukuran dilakukan dalam tiga waktu pengukuran. Tiga waktu pengukuran tersebut terdiri atas suhu udara yang mewakili waktu pagi hari, siang hari, dan sore hari. Sementara itu, pengamatan suhu udara dari aspek area pengukuran terdiri atas area di dalam taman yakni, area perkerasan, area tutupan rumput, dan area di bawah naungan pohon, maupun area di luar taman penelitian. Hasil pengukuran suhu udara pada tiga taman kota yang diteliti disajikan pada Gambar 16. 

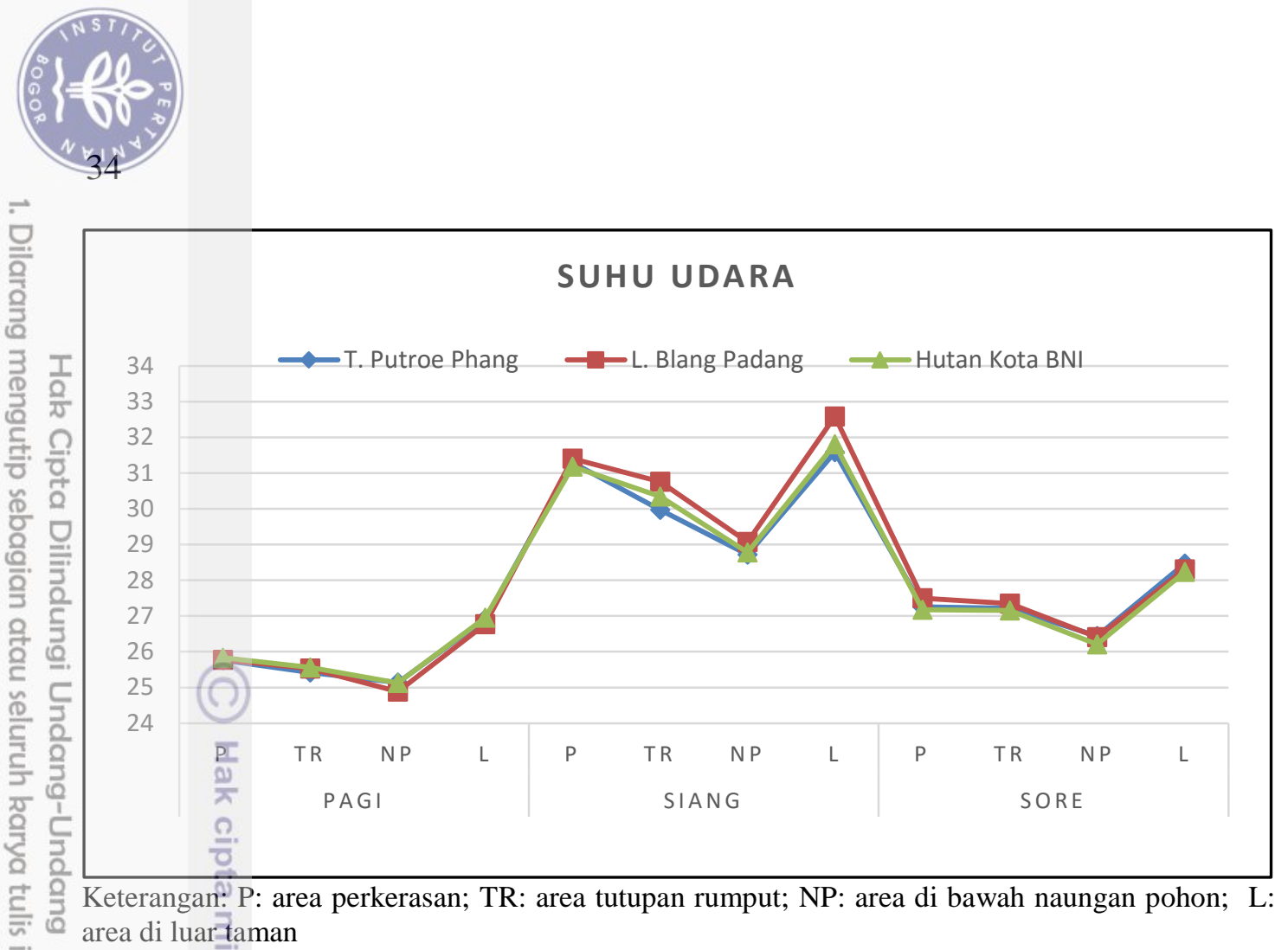

Gambar 16 Suhu udara rata-rata di tiga lokasi penelitian

Grafik pengukuran suhu udara pada tiga lokasi penelitian yaitu di Taman Putroe Prang (TPP), Lapangan Blang Padang (LBP), dan Hutan Kota BNI (HKB) menunjukkan hasil yang relatif sama. Suhu udara paling tinggi pada ketiga lokasi penelitian baik saat pengukuran di pagi hari maupun saat pengukuran di siang hari dan sore hari berada pada area di luar taman. Selisih nilai suhu udara antara area ukur di dâlam taman dan di luar taman pada pagi hari yaitu sebesar $1.6^{\circ} \mathrm{C}$ di TPP dan $1.5^{\circ} \overline{\mathrm{C}}$ di LBP dan HKB. Selisih nilai suhu udara antara area ukur di dalam taman dañ di luar taman pada pengukuran siang hari yaitu sebesar $1.5^{\circ} \mathrm{C}$ di TPP, $2.3^{\circ} \mathrm{C}$ di $\mathrm{LBP}$, dan $1.5^{\circ} \mathrm{C}$ di HKB. Sementara itu, selisih nilai suhu udara pada sore hari antara area ukur di dalam taman dan di luar taman, yaitu sebesar $1.5^{\circ} \mathrm{C}$ di TPP, $1.2^{\circ} \mathrm{C}$ didßBP, dan $1.6^{\circ} \mathrm{C}$ di HKB.

Suhú udara di pagi hari pada berbagai area ukur menunjukkan nilai tertinggi pada area luar > perkerasan > tutupan rumput > naungan pohon. Nilai tersebut serupa pada tiga bentuk taman yang diukur. Suhu udara tertinggi di pagi berada area luar dari $\mathrm{HKB}$ dengan nilai $27.6{ }^{\circ} \mathrm{C}$, luar dari TPP dengan nilai $27.5^{\circ} \mathrm{C}$, dan luar dari LBP dengan nilai $27.1^{\circ} \mathrm{C}$. Suhu terendah berada di area naungan pohon dari LBP dengan suhu $25.0^{\circ} \mathrm{C}$, naungan TPP dengan suhu $25.3{ }^{\circ} \mathrm{C}$, dan naungan pohon HKB dengan suhu $25.5{ }^{\circ} \mathrm{C}$. Pada waktu pengukuran pagi hari di tiga lokasi penelitian menghasilkan rentan suhu sekitar $25.0{ }^{\circ} \mathrm{C}$ sampai $27.6{ }^{\circ} \mathrm{C}$. Rentan suhu pada waktu pengukuran pagi hari memiliki nilai yang lebih rendah dibandingkan waktu pengukuran pada siang dan sore hari.

Pada saat pengukuran di siang hari, suhu terendah adalah area di bawah naungan pohon pada ketiga lokasi penelitian yaitu sebesar $28.6{ }^{\circ} \mathrm{C}$ di TPP, $29.1^{\circ} \mathrm{C}$ di LBP, dan $29.9^{\circ} \mathrm{C}$ di HKB. Suhu udara pada lokasi penelitian di Lapangan Blang Padang mempunyai suhu udara yang lebih tinggi dibandingkan suhu udara di lokasi penelitian Taman Kota Putroe Phang dan Hutan Kota BNI. Hal ini dikarenakan adanya pengaruh dari jumlah vegetasi pohon pada lokasi penelitian Lapangan Blang Padang yang lebih sedikit dibandingkan di lokasi penelitian Taman Kota Putroe Phang dan Hutan Kota BNI yang mempunyai vegetasi dominan berupa 
pohon. Berdasarkan Purnomo (2003), keberadaan vegetasi pohon dapat menurunkan suhu udara karena dapat melakukan proses evapotranspirasi dan adanya bayangan tajuk pohon yang dapat menjadi naungan bagi area di bawahnya. Suhu tertinggi siang hari terdapat di area ukur luar dari taman yaitu sebesar $32.8^{\circ} \mathrm{C}$ di LBP, $32.5^{\circ} \mathrm{C}$ di $\mathrm{HKB}$, dan $31.5^{\circ} \mathrm{C}$ di TPP. Nilai rata-rata suhu udara pada ketiga lokasi penelitian dijelaskan pada tabel 11.

Tabel 11 Rata-rata suhu udara tiga lokasi

\begin{tabular}{|c|c|c|c|c|}
\hline \multirow{2}{*}{ Waktu } & \multirow{2}{*}{ Titik Pengamatan } & \multicolumn{3}{|c|}{ Suhu Udara pada Lokasi $\left({ }^{\circ} \mathrm{C}\right)$} \\
\hline & & T. Putroe Phang & L. Blang Padang & H. Kota BNI \\
\hline \multirow{4}{*}{$\begin{array}{l}\text { Pagi } \\
\frac{2}{\pi}\end{array}$} & Perkerasan & 26.0 & 26.0 & 26.8 \\
\hline & Tutupan Rumput & 26.3 & 25.8 & 26.0 \\
\hline & Naungan Pohon & 25.3 & 25.0 & 25.5 \\
\hline & Luar Taman & 27.5 & 27.1 & 27.6 \\
\hline \multirow{4}{*}{ 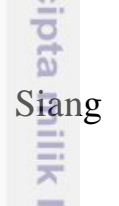 } & Perkerasan & 31.5 & 31.4 & 32.1 \\
\hline & Tutupan Rumput & 30.0 & 31.0 & 31.1 \\
\hline & Naungan Pohon & 28.6 & 29.1 & 29.9 \\
\hline & Luar Taman & 31.5 & 32.8 & 32.5 \\
\hline \multirow{4}{*}{ 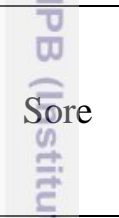 } & Perkerasan & 27.3 & 27.5 & 27.2 \\
\hline & Tutupan Rumput & 27.2 & 27.3 & 27.2 \\
\hline & Naungan Pohon & 26.4 & 26.4 & 26.3 \\
\hline & Luar Taman & 28.5 & 28.3 & 28.5 \\
\hline
\end{tabular}

Tabel 11 menunjukkan bahwa tiga lokasi penelitian mempunyai kesamaan dalam tingginya nilai suhu udara pada empat area pengukuran. Urutan besarnya nilai suhu udara pada empat area pengukuran pada saat pagi, siang, dan sore hari dari suhu paling tinggi ke suhu paling rendah yaitu area di luar taman (L) > area perkerasan $(\mathrm{P})>$ area tutupan rumput $(\mathrm{TR})>$ area di bawah naungan pohon $(\mathrm{NP})$. Habini menunjukkan bahwa suhu udara yang terdapat di luar taman dan di dalam taman yang diukur di atas perkerasan memiliki suhu yang lebih tinggi dibandingkan suhu udara yang diukur di atas vegetasi berupa tutupan rumput dan pohon.

Hasil pengukuran suhu udara pada sore hari di tiga lokasi penelitian menunjukkan nilai yang lebih rendah dibandingkan pengukuran pada siang hari, namun mempunyai suhu udara yang lebih tinggi dibandingkan pada pagi hari. Nilai rata-rata suhu udara pada tiga waktu pengukuran tersebut yaitu $27.1^{\circ} \mathrm{C}$ pada pagi hari, $31.3{ }^{\circ} \mathrm{C}$ pada siang hari, dan $28.1{ }^{\circ} \mathrm{C}$ pada sore hari. Kondisi tersebut dikarenakan posisi matahari yang berbeda antara pagi, siang, dan sore hari. Menurut Handoko (1993), suhu udara dapat mencapai nilai maksimum pada saat siang hari (13.00 waktu setempat) dan akan turun kembali hingga mencapai suhu minimum di pagi hari (sekitar pukul 05.00 waktu setempat). Hal ini terjadi karena setelah suhu maksimum tercapai maka radiasi yang keluar akan lebih besar dari radiasi yang datang sehingga radiasi yang datang dan digunakan untuk memanaskan suhu udara di sore hari akan menjadi semakin sedikit dibandingkan pada siang hari. Tjasyono (2008) juga menjelaskan bahwa peningkatan suhu udara pada variasi diurnal berkaitan dengan posisi/tingginya matahari yang kemudian akan memengaruhi penyebaran radiasi matahari yang dapat memanaskan suhu udara. Semakin mendekati siang hari, maka posisi matahari akan semakin tinggi. Jika matahari 
tinggi maka radiasi yang jatuh hampir tegak lurus pada permukaan bumi sehingga radiasi akan disebarkan di dalam area yang lebih sempit. Sementara itu, kondisi iklim di Kota Banda Aceh menurut data dari BMKG selama setahun terakhir dari $\frac{T}{2}$ mulai penelitian adalah sebagai berikut.

Tabel 12 Keadaan iklim rata-rata wilayah Banda Aceh

\begin{tabular}{|c|c|c|c|c|c|c|}
\hline $\begin{array}{l}\text { Waktu } \\
\text { (Bulan) }\end{array}$ & $\begin{array}{l}\text { Suhu } \\
\left({ }^{\circ} \mathrm{C}\right)\end{array}$ & $\begin{array}{l}\text { Kelembapan } \\
\text { rata-rata }(\%)\end{array}$ & $\begin{array}{l}\text { Curah } \\
\text { hujan } \\
\text { rata-rata } \\
(\mathrm{mm})\end{array}$ & $\begin{array}{c}\text { Rata-rata } \\
\text { penyinaran } \\
\text { matahari } \\
(\%)\end{array}$ & $\begin{array}{c}\text { Arah angin } \\
\text { terbanyak }\end{array}$ & $\begin{array}{l}\text { Kecepatan } \\
\text { angin rata- } \\
\text { rata }(k n o t)\end{array}$ \\
\hline Mar-14 & 27.0 & 81.0 & 7.0 & 69.4 & Tenggara & 6.0 \\
\hline Apr-14 & 27.3 & 80.0 & 112.0 & 66.3 & Tenggara & 4.0 \\
\hline May-14 & 27.8 & 80.0 & 78.0 & 49.1 & Tenggara & 5.0 \\
\hline Jun-14 & 29.0 & 70.0 & 69.3 & 68.8 & Barat Daya & 6.0 \\
\hline Jul-14 & 29.0 & 65.0 & 33.1 & 61.2 & Barat Daya & 7.0 \\
\hline Aug-14 & 27.3 & 65.0 & 133.5 & 55.4 & Barat Daya & 5.0 \\
\hline Sep-14 & 26.8 & 80.0 & 141.1 & 44.6 & Barat & 5.0 \\
\hline Oct-14 & 26.2 & 86.0 & 466.5 & 44.8 & Tenggara & 4.0 \\
\hline Nov-14 三 & 26.6 & 84.0 & 510.7 & 48.1 & Tenggara & 5.0 \\
\hline Dec-14 즈 & 26.4 & 85.0 & 483.1 & 40.8 & Tenggara & 5.0 \\
\hline Jan-15 & 26.5 & 81.0 & 6.3 & 60.0 & Tenggara & 6.0 \\
\hline Feb-15 & 26.3 & 79.0 & 4.0 & 64.0 & Tenggara & 5.0 \\
\hline $\begin{array}{c}\text { Rata- } \\
\text { rata }\end{array}$ & 27.2 & 78.0 & 170.4 & 56.0 & Tenggara & 5.3 \\
\hline
\end{tabular}

(Sumber: BMKG Blang Bintang Banda Aceh)

Data dari hasil pengukuran terhadap suhu udara dianalisis secara statistik. Hasil dartanalisis pada ketiga lokasi penelitian didapatkan hasil yang relatif sama, yaitu terdäpat paling sedikit satu perlakuan waktu (pagi, siang, dan sore hari) dan area ukur (perkerasan, di atas tutupan rumput, di bawah naungan pohon, dan di luar taman) yang dapat memengaruhi besarnya nilai suhu udara. Berdasarkan uji lanjut pada lokași penelitian TPP dan LBP (Lampiran 3 dan 4) terdapat perbedaan antara waktu pengukuran di pagi hari, siang hari, dan sore hari pada suhu udara yang didapatkan, serta terdapat perbedaan pada area pengukuran perkerasan dengan area di bawah naungan pohon, area luar taman dengan area di bawah naungan pohon, dan area di atas tutupan rumput terhadap suhu yang didapatkan. Pada area perkerasan dan area di atas rumput tidak terdapat perbedaan terhadap suhu udara. Sementara itu, hasil pada lokasi penelitian HKB menghasilkan bahwa terdapat perbedaan antara waktu pengukuran saat pagi hari, siang hari, dan sore hari, serta terdapat perbedaan suhu yang signifikan pada area pengukuran perkerasan dengan area di bawah naungan pohon, area luar taman dengan area di atas rumput dan di bawah naungan pohon.

Radiasi matahari dapat meningkatkan panas elemen lanskap yang terdapat pada suatu tapak. Semakin licin dan terang permukaan suatu material, maka akan semakin banyak radiasi matahari yang dipantulkan. Pohon yang memiliki kanopi dan menghasilkan bayangan, mampu mencegah dan menyerap radiasi matahari hingga $90 \%$. Kanopi pohon yang padat berfungsi sebagai penghalang (obstruction) radiasi matahari, sedangkan kanopi yang terbuka berfungsi sebagai penyaring (filtration) radiasi matahari. Sementara itu, rumput dan groundcover efektif untuk mengurangi radiasi matahari pada permukaan tanah (Brooks 1988). 
Tabel 13 Suhu rata-rata pada berbagai area ukur

\begin{tabular}{cc|c|c}
\hline \multirow{2}{*}{ Area Ukur } & \multicolumn{3}{c}{ Suhu Udara pada Lokasi $\left({ }^{\circ} \mathrm{C}\right)$} \\
\cline { 2 - 4 } & T. Putroe Phang & L. Blang Padang & Hutan Kota BNI \\
\hline Perkerasan & $28.1 \mathrm{~b}$ & $28.2 \mathrm{~b}$ & $28.1 \mathrm{c}$ \\
Tutupan Rumput & $27.5 \mathrm{~b}$ & $27.9 \mathrm{~b}$ & $27.7 \mathrm{~b}$ \\
Naungan Pohon & $26.8 \mathrm{a}$ & $26.8 \mathrm{a}$ & $26.7 \mathrm{a}$ \\
Luar & $29.0 \mathrm{c}$ & $29.2 \mathrm{c}$ & $29.0 \mathrm{~d}$ \\
\hline
\end{tabular}

Ket: Angka yang diikuti huruf yang sama pada kolom sama tidak berbeda nyata menurut Uji Duncan's Multiple Range.

Tabel 14 Suhu rata-rata pada berbagai waktu ukur

\begin{tabular}{lc|c|c}
\hline \multirow{2}{*}{ Waktu Ukur } & \multicolumn{3}{c}{ Suhu Udara pada Lokasi $\left({ }^{\circ} \mathrm{C}\right)$} \\
\cline { 2 - 4 } & T. Putroe Phang & L. Blang Padang & Hutan Kota BNI \\
\hline Pagi hari & $25.8 \mathrm{a}$ & $25.7 \mathrm{a}$ & $25.9 \mathrm{a}$ \\
Siang hari & $30.4 \mathrm{c}$ & $31.0 \mathrm{c}$ & $30.5 \mathrm{c}$ \\
Sore hari & $27.3 \mathrm{~b}$ & $27.4 \mathrm{~b}$ & $27.2 \mathrm{~b}$ \\
\hline
\end{tabular}

Ket: Angka yang diikuti huruf yang sama pada kolom sama tidak berbeda nyata menurut Uji

Duncan's Multiple Range.

Dari ketiga tempat penelitian, yang memiliki interaksi waktu dan area ukur terhädap suhu hanya di Hutan Kota BNI saja. Hasil uji dengan selang kepercayaan $95 \%$ menunjukkan ada interaksi antara waktu (pagi, siang, dan sore hari) dan area ukư (perkerasan, tutupan rumput, naungan pohon, dan luar taman) terhadap suhu di Hutan Kota BNI. Berikut adalah interaksi suhu udara dan area ukur terhadap suhu pada Hutan Kota BNI terlihat pada tabel di bawah ini.

Tabel 15 Interaksi suhu antara waktu dan area ukur di Hutan Kota BNI

\begin{tabular}{|c|c|c|c|c|c|}
\hline \multirow{2}{*}{$\frac{3}{3}$} & \multirow{2}{*}{ Waktu } & \multicolumn{4}{|c|}{ Area Ukur } \\
\hline & & Perkerasan & Tutupan Rumput & Naungan Pohon & Luar \\
\hline \multirow{3}{*}{ 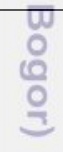 } & Pagi & $25.8 \mathrm{~b}$ & $25.6 \mathrm{ab}$ & $25.1 \mathrm{a}$ & $27.0 \mathrm{c}$ \\
\hline & Siang & $31.2 \mathrm{f}$ & $30.3 \mathrm{e}$ & $28.8 \mathrm{~d}$ & $31.8 \mathrm{f}$ \\
\hline & Sore & $27.2 \mathrm{c}$ & $27.2 \mathrm{c}$ & $26.2 \mathrm{~b}$ & $28.2 d$ \\
\hline
\end{tabular}

Ket: Angka yang diikuti huruf yang sama pada baris dan kolom tidak berbeda nyata menurut Uji Duncan's Multiple Range

Perbedaan suhu udara di area ukur disebabkan karena perbedaan fisik dari elemen tersebut. Akbari (2008) dalam Rushayati et al. (2011) menyatakan bahwa radiasi surya yang sampai ke permukaan akan mengalami pemantulan dan penyerapan radiasi. Semua jenis tutupan lahan memiliki nilai albedo. Albedo adalah perbandingan antara radiasi surya yang dipantulkan dengan radiasi yang datang. Vegetasi berdaun lebar memiliki nilai albedo 0.15 sampai 0.18 , sedangkan rumput memiliki albedo 0.25 . Lahan terbangun berupa beton memiliki nilai albedo 0.55 , sedangkan jalan beraspal memiliki nilai albedo $0.04-0.12$.

\section{Analisis Taman Kota Terhadap Kelembapan}

Berdasarkan hasil pengukuran kelembapan pada empat area ukur di pagi hari, siang hari, dan sore hari didapatkan nilai kelembapan sebesar $67 \%$ sampai dengan $83 \%$ di TPP, $65 \%$ sampai dengan $84 \%$ di LBP, dan $70 \%$ sampai dengan $84 \%$ di $\mathrm{HKB}$. Nilai kelembapan paling tinggi pada tiga lokasi penelitian berada pada area 


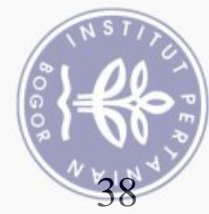

naungan di bawah pohon saat pengukuran pagi dan sore hari. Nilai kelembapan pada area di bawah naungan pohon saat pagi hari sebesar $83 \%$ pada Taman Kota Putroe Phang, $84 \%$ pada Lapangan Blang Padang, dan $84 \%$ pada Hutan Kota BNI. Nilai kelembapan pada saat sore hari sebesar $83 \%$ pada Taman Kota Putroe Phang, $84 \%$ pada Lapangan Blang Padang, dan $83 \%$ pada Hutan Kota BNI. Nilai ratarata hasil pengukuran kelembapan dari tiga lokasi penelitian disajikan pada Gambar 17.

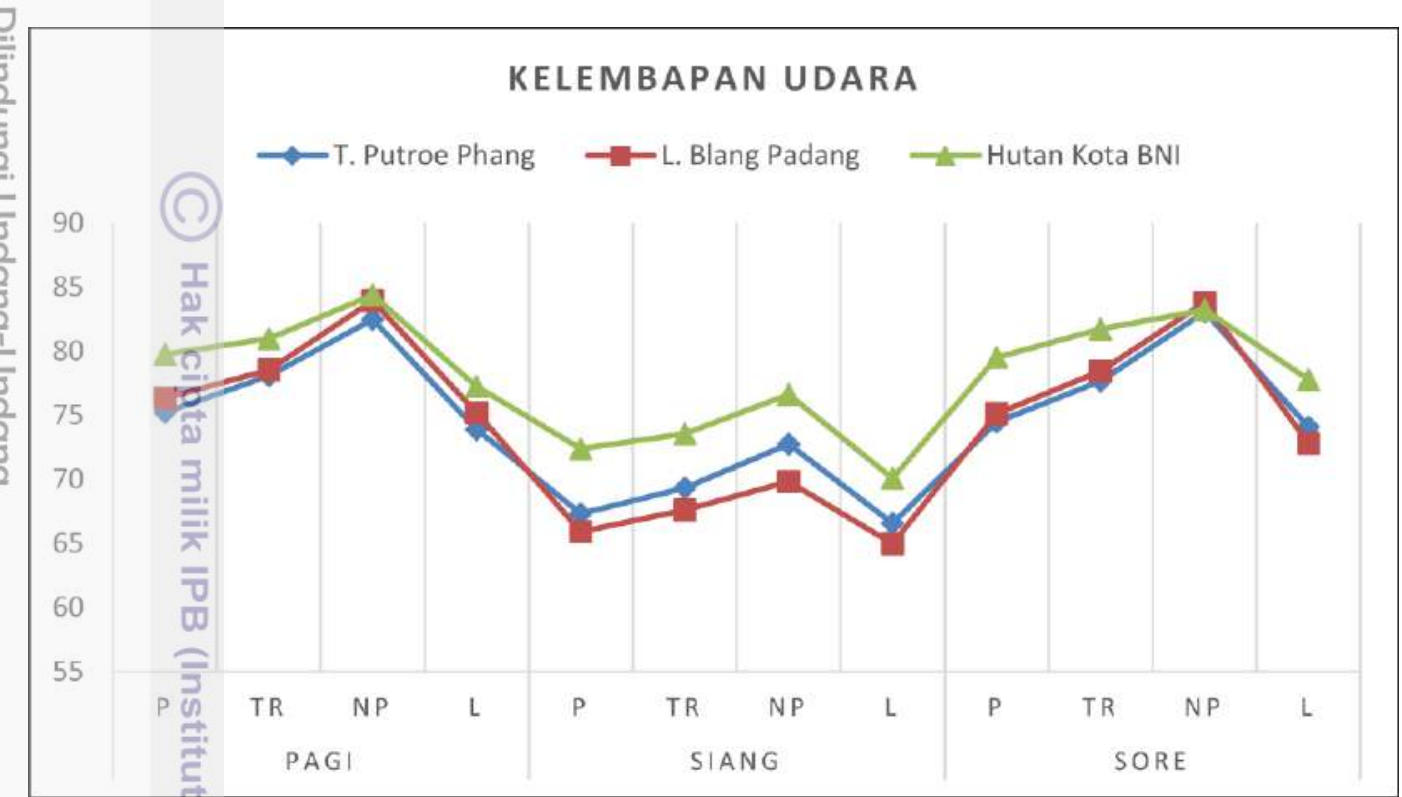

Ket: P: area perkerasan; TR: area tutupan rumput; NP: area di bawah naungan pohon;

L: area di luar taman

Gambar 17 Kelembapan rata-rata di tiga lokasi penelitian

Gambar 17 memperlihatkan bahwa kelembapan udara pada area ukur dari nilai terbesar hingga terkecil adalah area naungan di bawah pohon (NP) $>$ area tutupan rumput $(\mathrm{TR})>$ area perkerasan $(\mathrm{P})>$ area di luar taman $(\mathrm{L})$. Hal ini menunjukkan bahwa besarnya nilai suhu udara berbanding terbalik dengan besarnya nilai kelembapan udara. Area ukur yang terdapat vegetasi rumput dan pohon memiliki nilai kelembapan yang lebih tinggi dibandingkan area yang tidak terdapat vegetasi. Tingginya kelembapan disebabkan oleh adanya bayangan tajuk pohon yang menghalangi area di bawahnya sehingga area yang terdapat di bawahnya tidak terkena sinar matahari secara langsung. Hal ini diperlihatkan oleh lebih tingginya nilai kelembapan pada area ukur di dalam taman yang mempunyai vegetasi lebih banyak dibandingkan area ukur di luar taman.

Selisih nilai kelembapan antara di dalam taman dengan di luar taman pada pagi hari di ketiga lokasi penelitian sebesar $4.7 \%$ di Taman Putroe Phang, $4.6 \%$ di Lapangan Blang Padang dan Hutan Kota BNI. Selisih kelembapan siang hari sebesar 2.7\% di Taman Putroe Phang, 3.0 \% di Lapangan Blang Padang, dan $4.3 \%$ di Hutan Kota BNI. Selisih nilai kelembapan pada sore hari antara area pengukuran di dalam taman dengan di luar taman yaitu $4.7 \%$ di Taman Putroe Phang, $6 \%$ di Lapangan Blang Padang, dan 3.6 \% di Hutan Kota BNI. Salah satu faktor yang menyebabkan perbedaan nilai tersebut adalah karena sifat dari permukaan fisiknya, hal ini hampir sama dengan penyebab perbedaan nilai pada suhu udara. Nilai ratarata kelembapan udara pada tiga lokasi penelitian disajikan pada Tabel 16. 
Tabel 16 Rata-rata kelembapan udara tiga lokasi penelitian

\begin{tabular}{|c|c|c|c|c|}
\hline \multirow{2}{*}{ Waktu } & \multirow{2}{*}{$\begin{array}{c}\text { Area } \\
\text { Pengamatan }\end{array}$} & \multicolumn{3}{|c|}{ Kelembapan Udara pada Lokasi (\%) } \\
\hline & & T. Putroe Phang & L. Blang Padang & H. Kota BNI \\
\hline \multirow{4}{*}{ Pagi } & Perkerasan & 75 & 76 & 80 \\
\hline & Tutupan Rumput & 78 & 79 & 81 \\
\hline & Naungan Pohon & 83 & 84 & 84 \\
\hline & Luar Taman & 74 & 75 & 77 \\
\hline \multirow{4}{*}{ Siang } & Perkerasan & 67 & 66 & 72 \\
\hline & Tutupan Rumput & 69 & 68 & 74 \\
\hline & Naungan Pohon & 73 & 70 & 77 \\
\hline & Luar Taman & 67 & 65 & 70 \\
\hline \multirow{4}{*}{$\begin{array}{l}\frac{T}{\bar{y}} \\
\text { Sore } \\
\frac{0}{0}\end{array}$} & Perkerasan & 75 & 75 & 80 \\
\hline & Tutupan Rumput & 78 & 78 & 82 \\
\hline & Naungan Pohon & 83 & 84 & 83 \\
\hline & Luar Taman & 74 & 73 & 78 \\
\hline
\end{tabular}

Tabel 16 menunjukkan bahwa lokasi penelitian Lapangan Blang Padang mempunyai nlai rata-rata kelembapan yang lebih rendah dibandingkan lokasi penelitian TPP dan HKB pada waktu pengukuran di siang hari. Hal ini disebabkan oleh adanya jumlah vegetasi pohon di lokasi penelitian TPP dan HKB yang lebih banyak dibandingkan di lokasi penelitian Lapangan Blang Padang. Menurut Asiani (20ํㄱ), lokasi dengan jumlah vegetasi yang lebih banyak memiliki kelembapan udara yang lebih tinggi, sedangkan lokasi dengan vegetasi yang lebih sedikit memiliki kelembapan udara yang lebih rendah. Kelembapan yang tinggi disebabkan oleh penambahan uap air hasil evapotranspirasi. Evapotranspirasi juga menghilangkan panas sehingga suhu udara di sekitar tanaman menjadi lebih rendah.

Berdasarkan hasil analisis statistik antara waktu pengukuran (pagi, siang, dan sore hari) dan area ukur (perkerasan, di atas tutupan rumput, di bawah naungan pohon, dan di luar taman) terhadap kelembapan udara pada ketiga lokasi penelitian didapatkan bahwa tidak terdapat interaksi yang signifikan (lampiran 7) antara waktu pengukuran dan area ukur yang berpengaruh secara nyata terhadap kelembapan udara. Selain itu, dengan menggunakan selang kepercayaan $95 \%$ bagi nilai rata-rata kelembapan pada setiap waktu perlakuan, tampak pengamatan pada waktu siang hari memberikan nilai kelembapan yang paling rendah yaitu $69.0 \%$ pada TPP, $67.0 \%$ pada LBP, dan $73.1 \%$ pada HKB. Nilai kelembapan paling tinggi berada pada waktu pagi hari yang terdapat pada TPP sebesar $77.4 \%$ dan HKB sebesar $78.5 \%$, serta sore hari pada HKB sebesar $80.9 \%$ (Lampiran 9). Sementara itu, pada area pengukuran nilai kelembapan paling rendah berada pada area di luar taman sebesar $71.5 \%$ pada TPP, $71.0 \%$ pada LBP, dan $75.0 \%$ pada HKB. Area pengukuran yang mempunyai nilai kelembapan paling tinggi pada tiga lokasi penelitian berada pada area di bawah naungan pohon sebesar $79.4 \%$ pada TPP, $79.0 \%$ pada LBP, dan $81.8 \%$ pada HKB.

Data hasil pengamatan mengenai kelembapan udara dianalisis lebih lanjut untuk mengetahui waktu pengamatan atau area ukur yang memiliki perbedaan nilai. Hasil dari uji Anova pada ketiga lokasi penelitian menunjukkan bahwa pada waktu pengukuran di pagi hari memiliki perbedaan yang signifikan dengan waktu péngukuran di siang hari, dan waktu pengukuran di siang hari berbeda secara 


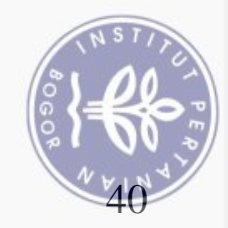

signifikan dengan pengukuran pada saat sore hari (nilai $\alpha<5 \%$ ). Selain itu, terdapat perbedaan yang signifikan antara area ukur perkerasan $(\mathrm{P})$ dengan area ukur di bawah naungan pohon (NP), dan area ukur di atas rumput (TR) yang berbeda secara $\frac{T}{2}$ signifikan dengan titik ukur naungan pohon (NP) dan area luar taman (L), serta area ukur naungan pohon berbeda secara signifikan dengan area ukur di luar taman (nilai $\alpha<5 \%)$ (Lampiran 7, 8, dan 9).

Tabel 17 Kelembapan rata-rata pada berbagai area ukur

\begin{tabular}{cc|c|c}
\hline \multirow{2}{*}{ Area Ukur } & \multicolumn{3}{c}{ Kelembapan Udara pada Lokasi (\%) } \\
\cline { 2 - 4 } & T. Putroe Phang & L. Blang Padang & H. Kota BNI \\
\hline Perkerasan & $72.4 \mathrm{a}$ & $72.5 \mathrm{ab}$ & $77.3 \mathrm{~b}$ \\
Tutupan Rumput & $75.0 \mathrm{~b}$ & $74.9 \mathrm{~b}$ & $78.8 \mathrm{~b}$ \\
Naungan Pohon & $79.4 \mathrm{c}$ & $79.2 \mathrm{c}$ & $81.4 \mathrm{c}$ \\
Luar & $71.5 \mathrm{a}$ & $71.0 \mathrm{a}$ & $75.0 \mathrm{a}$ \\
\hline Ket : Angka yang diikuti huruf yang sama pada kolom sama tidak berbeda nyata menurut Uji \\
Dunean's Multiple Range. \\
\multicolumn{4}{c}{ Kelembapan Udara pada Lokasi (\%) } \\
Tabel 18 Kelembapan rata-rata pada berbagai waktu ukur \\
\hline \multicolumn{3}{c}{ W. Blang Padang } \\
Waktu Kota BNI \\
Pengukuran & T. Putroe Phang & 78.5b & $80.6 \mathrm{~b}$ \\
\hline Pagihari & $77.4 \mathrm{~b}$ & $67.1 \mathrm{a}$ & $73.2 \mathrm{a}$ \\
Sianghari & $69.0 \mathrm{a}$ & $77.6 \mathrm{~b}$ & $80.6 \mathrm{~b}$ \\
Sorehari & $77.3 \mathrm{~b}$
\end{tabular}

Ket : Angka yang diikuti huruf yang sama pada kolom sama tidak berbeda nyata menurut Uji Duncan's Multiple Range.

\section{Analisis Taman Kota Terhadap Kenyamanan Manusia}

Penentuan indeks kenyamanan manusia yang diukur pada penelitian ini berdasarkan thermal comfort dengan metode Temperature Humidity Index (THI) yang menerapkan suhu udara dan kelembapan relatif. Nilai indeks yang dihitung berdasarkan persamaan Nieuwolt menghasilkan tiga kategori yaitu nyaman, cukup nyaman, dan tidak nyaman. Kategori nyaman berdasarkan metode THI pada rentang 21.0 hingga 24.0 dapat tercapai dengan mengombinasikan nilai suhu udara dan kelembapan relatif yang berbeda (Gambar 18).

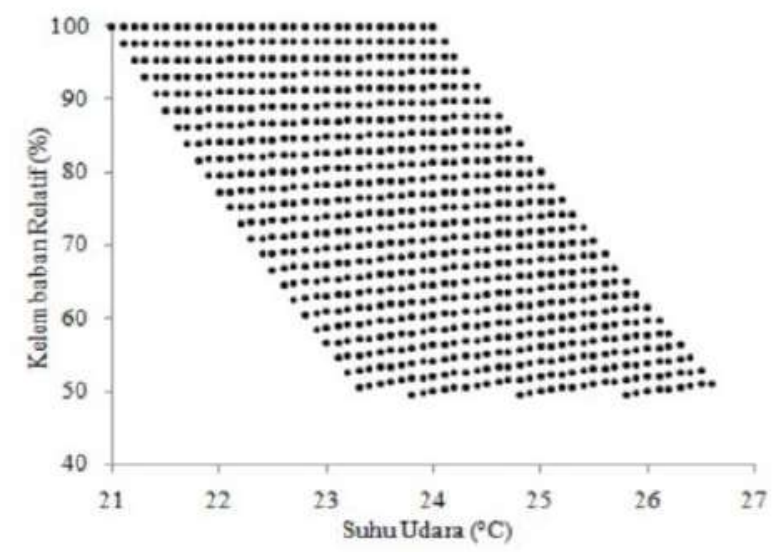

Gambar 18 Kategori nyaman berdasarkan metode THI dengan kombinasi nilai suhu udara dan kelembapan relatif yang berbeda 
Hubungan antara suhu udara dengan kenyamanan termal pada metode THI berbanding lurus, semakin meningkatnya suhu udara maka nilai indeks kenyamanan akan semakin tinggi. Gambar 18 dapat menjelaskan bahwa semakin meningkatnya suhu udara disertai penurunan kelembapan udara akan menghasilkan indeks kenyamanan yang baik hingga pada batasan tertentu. Suhu udara terendah untuk mencapai kategori nyaman harus bernilai $21.0^{\circ} \mathrm{C}$ dengan kelembapan $100 \%$. Nilai suhu udara dan kelembapan tersebut akan menghasilkan kategori nyaman dengan nilai indeks THI pada batas yang paling bawah yaitu 21.0. Kategori nyaman dengan nilai THI pada batas paling atas juga dapat tercapai dengan kondisi suhu udara sebesar $26.6{ }^{\circ} \mathrm{C}$ dan kelembapan udara sebesar $50 \%$.

Nilai suhu dan kelembapan udara yang diperoleh di empat area ukur menghasilkan nilai THI yang bervariasi. Kategori kenyamanan pada empat area ukur dilihat pada empat waktu yang berbeda yaitu pagi hari, siang hari, sore hari, dan rata-rata harian (Gambar 19).

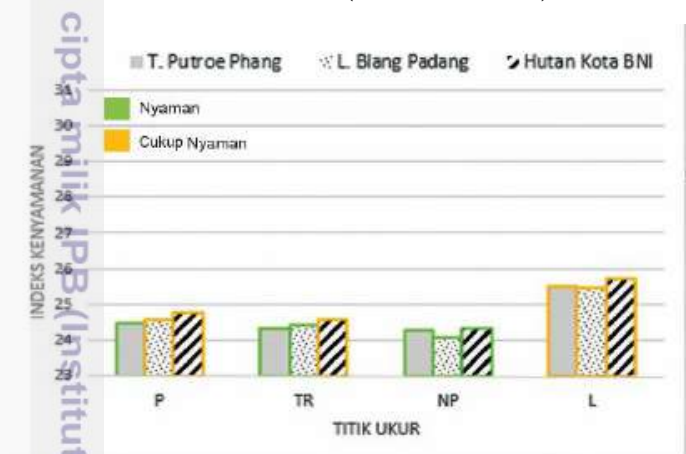

(a)

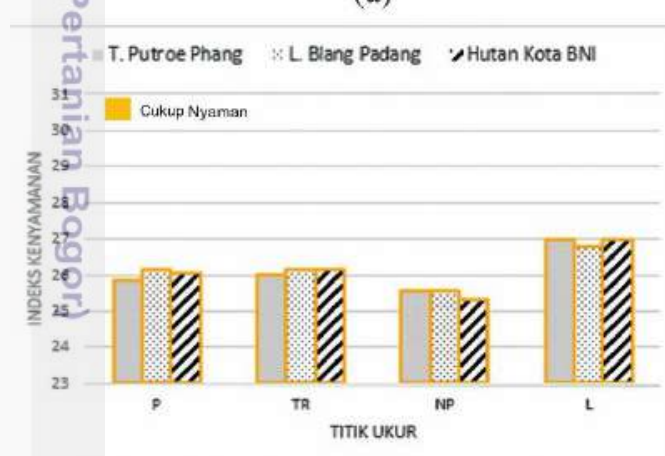

(c)

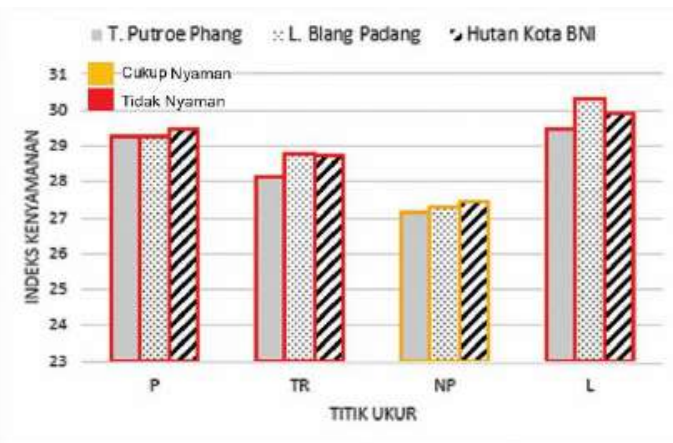

(b)

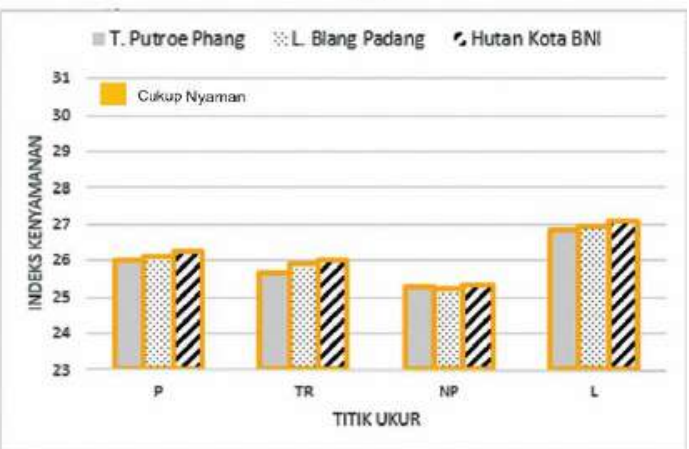

(d)

Gambar 19 Indeks kenyamanan tiga lokasi penelitian pada pagi hari (a); siang hari (b); sore hari (c); dan harian (d)

Pagi hari di TPP sebagian besar termasuk ke dalam kategori nyaman, dan beberapa yang tergolong kategori cukup nyaman. THI dengan kategori nyaman meliputi area perkerasan di TPP, tutupan rumput di TPP, tutupan rumput LBP, dan naungan pohon di tiga taman kota. Area ukur luar taman pagi hari menunjukkan kondisi yang cukup nyaman dengan rentang THI 25-26, hal tersebut terjadi karena padatnya aktivitas kendaraan yang melaju di area luar taman (Gambar 19a).

Kenyamanan pada siang hari menunjukkan nilai pada rentang tidak nyaman untuk kawasan luar taman dan dalam taman, namun suhu di dalam taman pada area ukur di bawah naungan tergolong ke dalam kondisi cukup nyaman (Gambar 19b). Siang hari dengan suhu udara yang semakin meningkat akan memperburuk kondisi 
kenyamanan di wilayah tersebut. Suhu udara yang tinggi akan meningkatkan sensasi panas atau thermal dicomfort yang diterima oleh manusia yang akan memengaruhi kenyamanan manusia. Kawasan taman (naungan pohon) akan T memberikan kenyamanan di wilayah tersebut dibandingkan dengan kawasan di luarnya. Hal ini berkaitan dengan suhu udara dan kelembapan relatif yang terjadi di wilayah tersebut.

Pada sore hari seluruh lokasi pengamatan berada pada kategori cukup nyaman (Gambar 19c). Suhu udara di sore hari akan menjadi lebih rendah dibandingkan dengan siang hari sehingga kenyamanan yang dihasilkan pada sore hari akan lebih baik dibandingkan pada siang hari. Penanaman pohon yang dilakukan secara berkelompok akan memberikan manfaat yang lebih besar untuk menurunkan suhu udara. Penelitian ini juga menunjukkan hasil yang sama yaitu suhu pada kawasan taman yang lebih besar dan mempunyai pohon yang ditanam secara berkelompok akan menghasilkan suhu udara yang lebih rendah, sehingga tingkat kenyamanan yang diperoleh pun akan menjadi lebih baik. Hasil penilaian pada indeks kenyamanan harian (Gambar 19d) memperlihatkan bahwa seluruh kawasan memiliki kategori cukup nyaman. Kawasan taman akan memberikan cooling effect sehingga milai suhu udara di kawasan taman akan lebih rendah dibandingkan dengan kawasan luar taman. Shahidan et al. (2010) menjelaskan bahwa kawasan taman akan mendapatkan radiasi yang lebih sedikit akibat adanya proses transmisi. Semakin=sedikitnya radiasi yang diterima pada kawasan taman akan memungkinkan terjadinya penurunan suhu udara dan peningkatan kelembapan relatif di sekitar sehingga dapat memperbaiki kenyaman termal manusia. Panas yang lebih tinggi di luar taman akan menyebabkan kenyamanan termal yang lebih buruk dibandingkan di dalam taman. Kategori kenyamanan pada siang hari menunjukkan nilai pada rentang tidak nyaman untuk area perkerasan, tutupan rumput, dan luar dari taman. Berikut adalah tabel nilai rata-rata THI dari tiga bentuk taman kota yang diteliti.

Tabel 19Rata-rata nilai THI

\begin{tabular}{|c|c|c|c|c|}
\hline \multirow{2}{*}{ Waktu } & \multirow{2}{*}{ Titik Pengamatan } & \multicolumn{3}{|c|}{ Lokasi } \\
\hline & & T. Putroe Phang & L. Blang Padang & H. Kota BNI \\
\hline \multirow{4}{*}{ Pagi } & Perkerasan & 24 & 25 & 25 \\
\hline & Tutupan Rumput & 24 & 24 & 25 \\
\hline & Naungan Pohon & 24 & 24 & 24 \\
\hline & Luar Taman & 26 & 25 & 26 \\
\hline \multirow{4}{*}{ Siang } & Perkerasan & 29 & 29 & 29 \\
\hline & Tutupan Rumput & 28 & 29 & 29 \\
\hline & Naungan Pohon & 27 & 27 & 27 \\
\hline & Luar Taman & 29 & 30 & 30 \\
\hline \multirow{4}{*}{ Sore } & Perkerasan & 26 & 26 & 26 \\
\hline & Tutupan Rumput & 26 & 26 & 26 \\
\hline & Naungan Pohon & 26 & 26 & 25 \\
\hline & Luar Taman & 27 & 27 & 27 \\
\hline \multirow{4}{*}{ Harian } & Perkerasan & 26 & 26 & 26 \\
\hline & Tutupan Rumput & 26 & 26 & 26 \\
\hline & Naungan Pohon & 25 & 25 & 25 \\
\hline & Luar Taman & 27 & 27 & 27 \\
\hline
\end{tabular}


Secara keseluruhan dapat dilihat bahwa indeks kenyamanan di kawasan luar taman memiliki nilai yang selalu lebih tinggi dibandingkan di kawasan taman. Suhu udara yang lebih panas pada kawasan luar taman menjadi faktor yang dapat memberikan kenyamanan yang lebih buruk dibandingkan dengan kawasan yang memiliki RTH (taman) pada siang hari. Hal tersebut terjadi karena tidak adanya penghalang sinar matahari pada kawasan luar taman, sehingga sinar matahari langsung diterima oleh permukaan. Faktor lain yang memengaruhi kenyamanan manusia berdasarkan sensasi panas (thermal comfort) yang terasa adalah angin.

Kenyamanan udara suatu lokasi dipengaruhi besarnya suhu udara, kelembapan udara, kecepatan angin, dan radiasi matahari. Namun indeks kenyamanan pada penelitian ini dilihat dari dua faktor yakni suhu dan kelembapan udara. Tingkat kenyamanan termal bukan merupakan hasil penilaian tunggal, melainkan terdiri atas serangkaian kondisi dengan semakin tinggi suhu udara dan renđah kelembapan udara menyebabkan nilai THI menjadi tinggi dan kenyamanan berkurang, begitu pula sebaliknya. Berdasarkan Laurie (1986), manusia cenderung merasa nyaman jika berada pada interval nilai THI antara 21-27.

Angin dapat memengaruhi suhu udara di wilayah yang dilaluinya sehingga secâra tidak langsung akan memengaruhi kenyamanan manusia di wilayah tersebut. Lakitan (2002) menyatakan bahwa angin dapat mencampurkan lapisan udara antara udara panas dengan udara dingin serta antara udara lembap dengan udara kering. Suhu udara pada siang hari di suatu wilayah akan menjadi lebih rendah ketika terdapat angin yang berhembus melewati wilayah tersebut. Hal ini terjadi karena massa udara panas di wilayah tersebut akan terbawa oleh angin sehingga berkurangnya massa udara panas di wilayah tersebut akan menurunkan suhu udaranya. Suhu udara yang semakin rendah akan memperlemah sensasi panas yang diterima oleh manusia sehingga kondisi kenyamanan akan lebih membaik. Angin juga akan membawa panas dari tubuh manusia dan bangunan di sekitar sehingga wilayah tersebut akan terasa lebih sejuk (Shahidan et al. 2010 dalam Aprihatmoko 2013). Berdasarkan hal tersebut, Gomez et al. (2004) menyatakan bahwa faktor angin akan lebih terasa ketika musim panas. Begitu pula pada siang hari, jika di suatu wilayah tidak ada angin yang berhembus maka wilayah tersebut akan terasa panas dibandingkan dengan wilayah yang mendapatkan hembusan angin. Hal ini dikarenakan massa udara panas akan terperangkap di wilayah yang tidak terdapat angin yang melewatinya. Berdasarkan hasil yang didapat, maka Kota Banda Aceh dapat dikatakan memiliki kategori cukup nyaman. Penambahan RTH dalam bentuk taman kota di Kota Banda Aceh perlu dilakukan untuk memperbaiki kondisi kenyamanannya. Hal tersebut dikarenakan dari hasil yang didapat pada penelitian ini menunjukkan bahwa taman kota memiliki pengaruh positif terhadap kenyamanan manusia. Naungan yang diberikan oleh taman kota akan memberikan nilai THI yang lebih kecil (lebih nyaman) dibandingkan dengan kawasan luar taman kota. Oleh karena itu, keberadaan taman di perkotaan sangat penting untuk mengendalikan iklim mikro di perkotaan sehingga mendukung kondisi yang lebih nyaman di sebuah kota khususnya Kota Banda Aceh.

\section{Evaluasi Kualitas Estetika Lanskap}

Berdasarkan hasil penilaian kuesioner yang dilakukan oleh 50 responden mahasiswa departemen Arsitektur Lanskap semester 6 dan 8 terhadap 30 gambar 
lanskap baik pada Taman Putroe Phang, Lapangan Blang Padang, dan Hutan Kota BNI, maka diperoleh nilai SBE pada setiap gambar. Nilai SBE tersebut dijabarkan ke dalam grafik SBE pada masing-masing lokasi penelitian.

Tabel 20 Persentase kualitas estetika

\begin{tabular}{cccc}
\hline Kualitas & \multicolumn{3}{c}{ Lokasi Penelitian } \\
\cline { 2 - 4 } Estetika & TPP $(\%)$ & LBP $(\%)$ & HKB $(\%)$ \\
\hline Rendah & 47 & 10 & 13 \\
Sedang & 13 & 53 & 47 \\
Tinggi & 40 & 37 & 40 \\
\hline
\end{tabular}

\section{Taman Putroe Phang}

Berdasarkan penilaian terhadap 30 foto lanskap yang mewakili lanskap Taman Putroe Phang melalui metode SBE didapatkan persentase kualitas estetika sebagai berikut. Sebesar $40 \%$ foto lanskap termasuk ke dalam kategori nilai SBE tinggi, $13 \%$ pada pada kategori nilai SBE sedang, dan $47 \%$ pada kategori nilai SBE rendah. Hasil penilaian lanskap pada Taman Putroe Phang disajikan melalui grafik penilaian SBE pada Gambar 20.

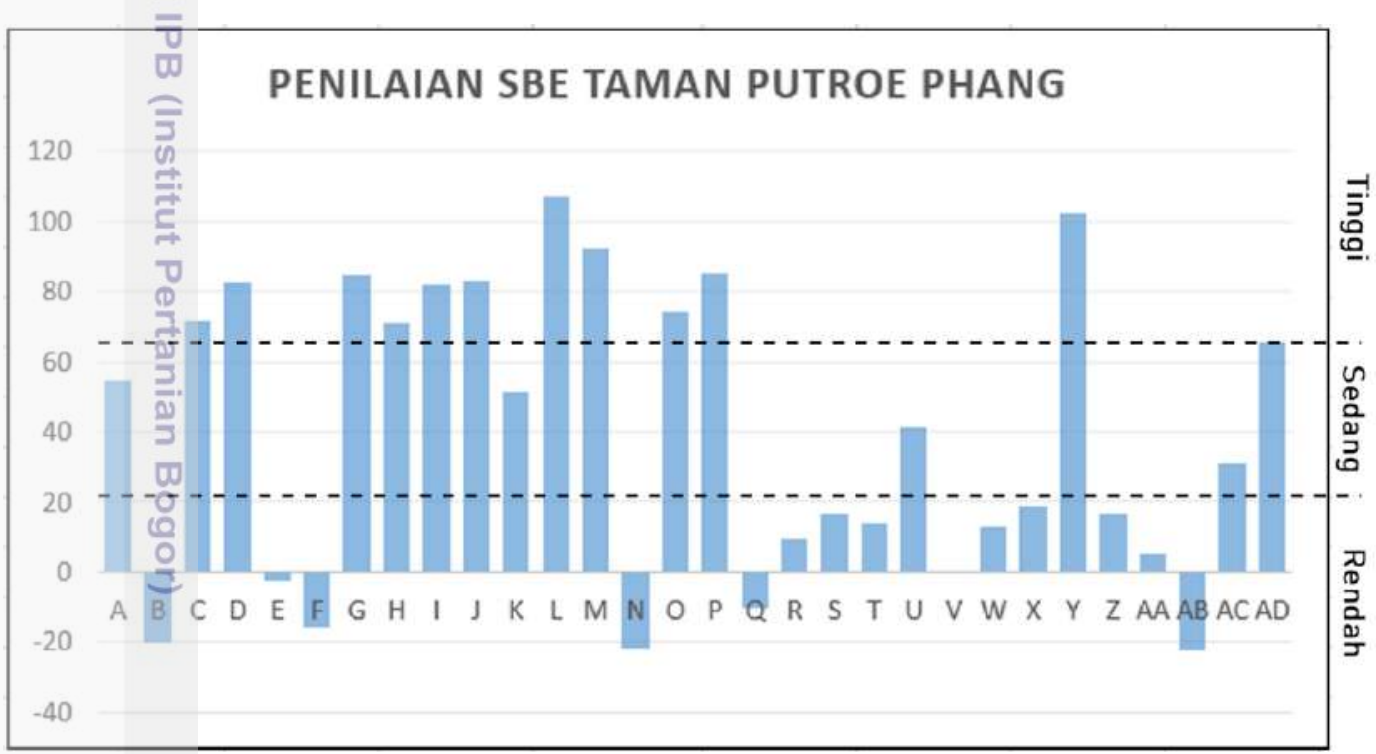

Gambar 20 Grafik nilai SBE Taman Putroe Phang

Gambar 20 menunjukkan bahwa terdapat 12 foto lanskap yang termasuk ke dalam kategori nilai SBE tinggi yaitu lanskap AD, C, D, G, H, I, J, L, M, O, P, dan Y. Lanskap A, AC, K, dan U termasuk ke dalam kategori nilai SBE sedang, sedangkan lanskap AA, AB, B, E, F, N, Q, R, S, T, V, W, X, dan Z termasuk ke dalam kategori nilai SBE rendah. Penilaian kualitas estetika lanskap tertinggi pada Taman Putroe Phang terdapat pada foto lanskap L dengan nilai SBE sebesar 107.0. Sebaliknya, nilai kualitas estetika lanskap terendah pada Taman Putroe Phang terdapat pada foto lanskap AB dengan nilai SBE sebesar -22.1. Foto lanskap dengan nilai SBE tertinggi dan terendah di Taman Putroe Phang disajikan pada Gambar 21. 

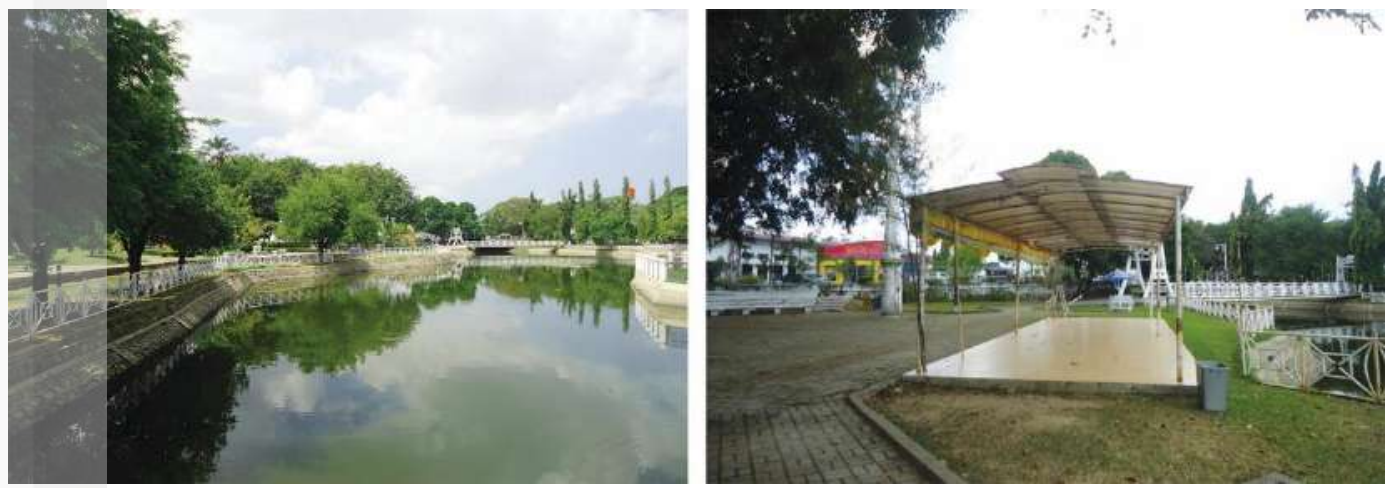

Gambar 21 Lanskap L dengan nilai SBE tertinggi (kiri), Lanskap AB dengan nilai SBE terendah (kanan)

Gambar 21 menunjukkan bahwa foto lanskap L sebagai lanskap dengan nilai SBE tertinggi dibentuk dari tiga elemen lanskap yaitu air, softscape (tanaman), dan hardscape (perkerasan). Elemen lanskap yang dominan adalah elemen air yang memberikan refleksi terhadap objek-objek yang ada di sekitarnya dan dipercaya dapât menjadikan suasana menjadi lebih nyaman. Pada lanskap L terdapat vegetasi yang disusun secara berulang menjadi border dan penaung yang dapat membentuk suatu kesatuan (unity). Pagar dan jembatan dengan bentuk yang menarik dan penggunaan warna putih memberi kesan harmonis serta memperkuat karakter taman sebagai taman bersejarah. Pantulan bayangan objek di sekeliling badan air juga menambah kesan harmonis terhadap alam. Sebaliknya, foto lanskap AB yang mempunyai nilai terendah tidak menerapkan prinsip desain kesatuan (unity), dan keseimbangan (balance) antara komposisi bangunan panggung dengan lingkungan sekitarnya. Bentuk fasad tenda dengan lingkungan di sekitarnya tidak memperlihatkan keseimbangan dan keserasian. Penggunaan vegetasi yang sangat minim diduga juga menjadi salah faktor yang menjadikan nilai SBE pada lanskap tersebut paling rendah di antara lanskap lainnya. Selain itu, vegetasi rumput yang menguning menunjukkan bahwa kurangnya pemeliharaan lanskap yang menjadi salah satu penyebab rendahnya nilai estetika. Berikut ini adalah tabel nilai kelompok SBE pada Taman Putroe Phang

Tabel 21 Kategori kualitas estetika lanskap Taman Kota Putroe Phang

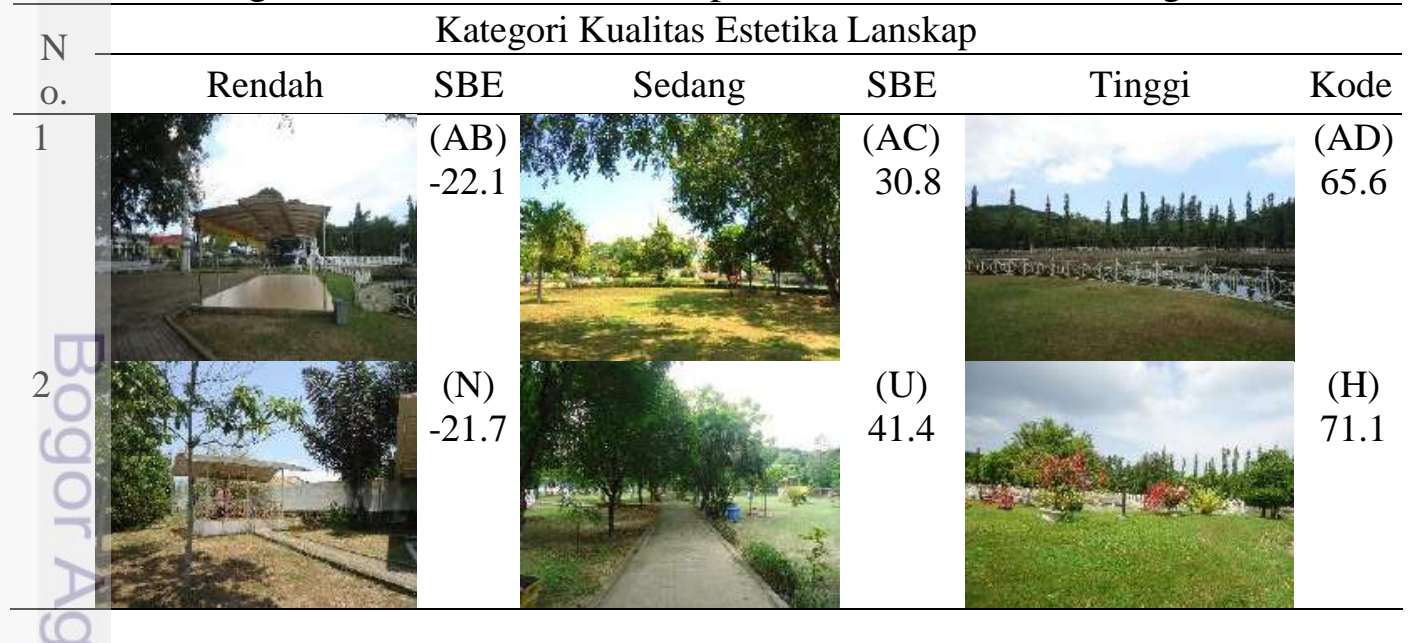



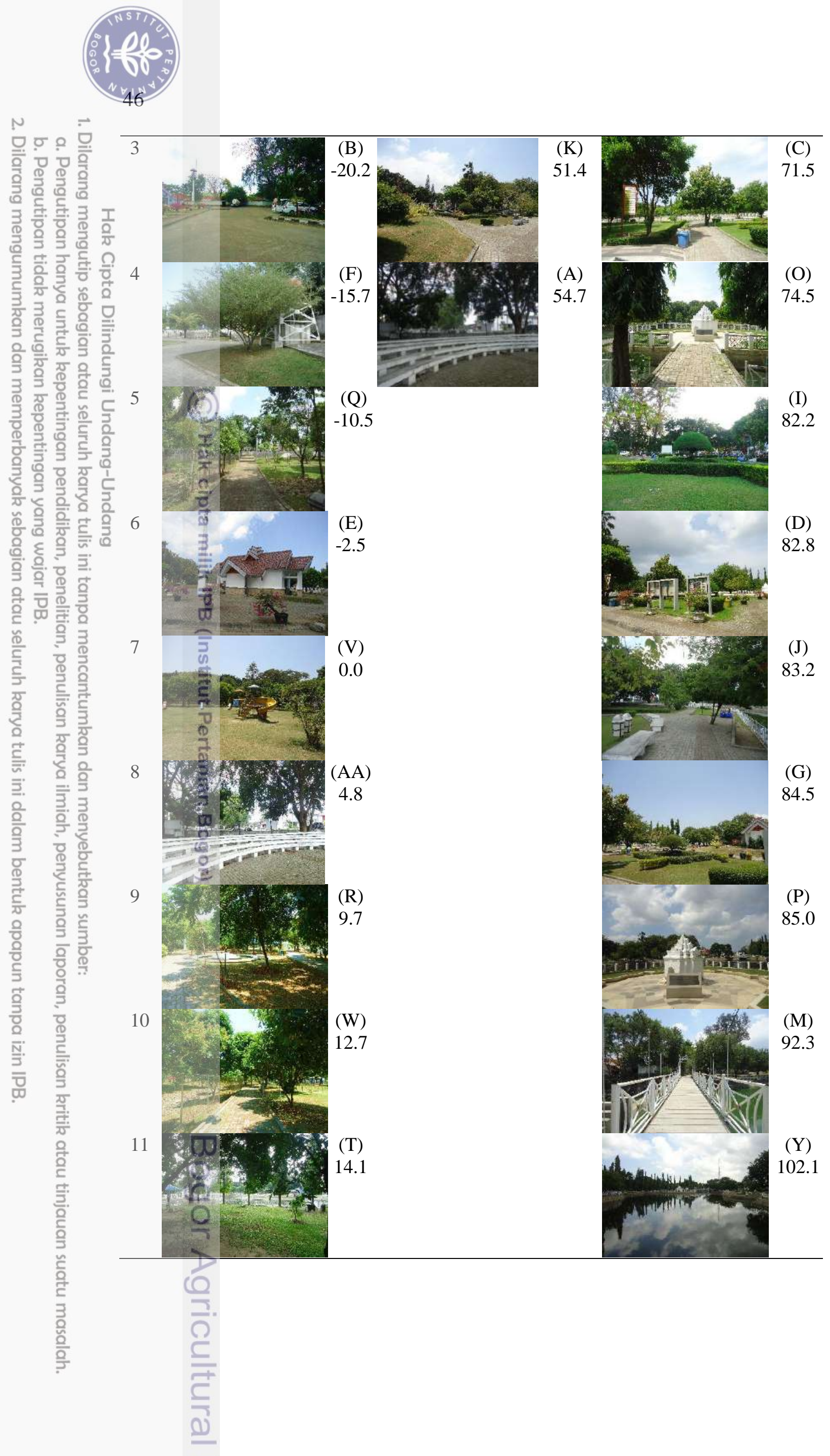


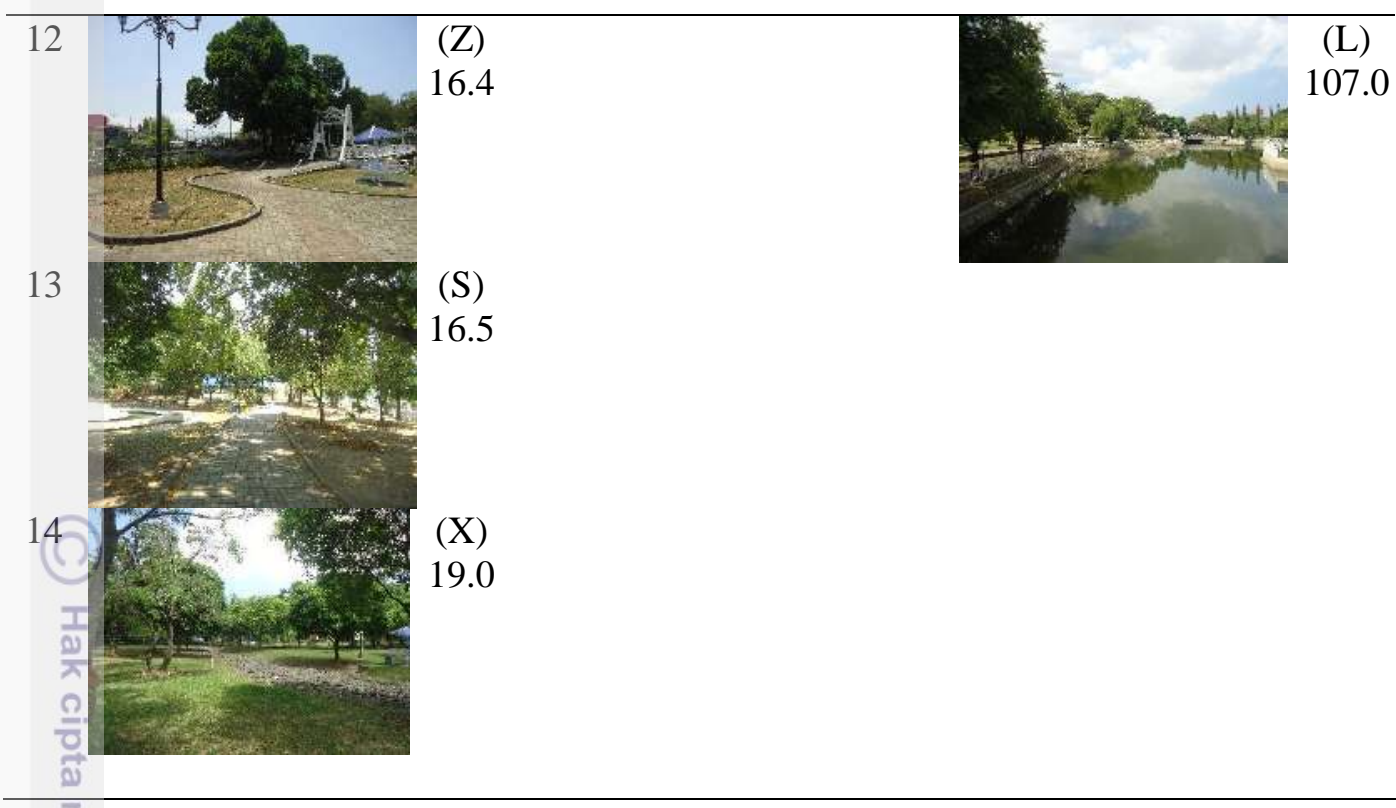

Tabel 21 menunjukkan lanskap yang termasuk ke dalam kategori estetika tinggi didominasi oleh lanskap yang mengombinasikan tiga elemen lanskap yaitu perkerasan, vegetasi, dan air. Tampilan lanskap dengan nilai SBE tinggi juga mampu memperlihatkan cakupan lanskap yang lebih luas, penggunaan vegetasi yang beranekaragam, dan suasana yang asri. Berdasarkan Suryandari (2000), lanskap dengan kualitas visual yang baik dipengaruhi oleh komposisi antara elemen keras dan elemen lunak yang harmonis sebagai elemen utama pembentuk lanskapnya. Selain itu, tingginya nilai estetika juga dipengaruhi oleh penggunaan prinsip-prinsip desain seperti irama dan pengulangan, aksentuansi, proporsi, serta adañya kerapihan dan kebersihan.

Sementara itu, sebagian besar lanskap yang termasuk ke dalam kategori estetika rendah merupakan lanskap yang kurang memerhatikan kaidah dalam prinsip desain, yakni tidak adanya kesatuan antara penggunaan dan pemilihan elemen keras dan elemen lunak (vegetasi). Selain itu, faktor lain yang menyebabkan lanskap berada dalam kategori estetika rendah dikarenakan adanya sampah berupa daun-daun kering dan kurangnya pengelolaan terhadap elemen lanskap khususnya pada vegetasi rumput yang tumbuh tidak merata dan berwarna kuning.

Secara keseluruhan, Taman Kota Putroe Phang didominasi oleh lanskap yang memiliki kualitas estetika rendah dan tinggi. Lanskap dengan kategori estetika rendah lebih dominan tersebar pada bagian utara dari taman. Dominasi lanskap kategori estetika rendah pada bagian utara taman disebabkan tidak adanya objek lanskap menarik yang dapat dilihat oleh pengunjung dan responden serta kurangya pemeliharaan pada area tersebut (Gambar 22). Sementara itu, lanskap dengan kategori estetika tinggi cenderung berada pada area yang memiliki objek lanskap menarik seperti area papan informasi, area display, pinto khop, dan area yang menghadap ke arah sungai. Lanskap dengan kualitas memiliki persentase paling rendah dan hanya ditemui pada empat foto lanskap saja. Empat foto lanskap dengan kategori estetika sedang terdapat pada pintu gerbang, area penerimaan, dan tepian sungai bagian utara. 


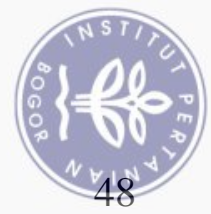

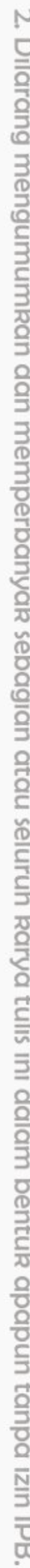

을

을 을 을

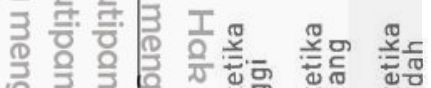

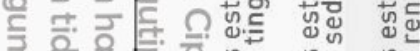

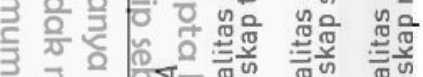

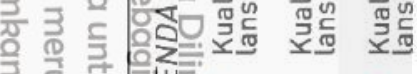

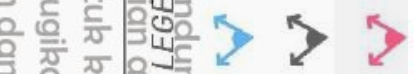

2
D.

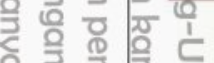

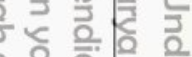

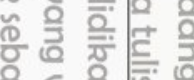

\& 罗辰

$\frac{10}{3}$

을
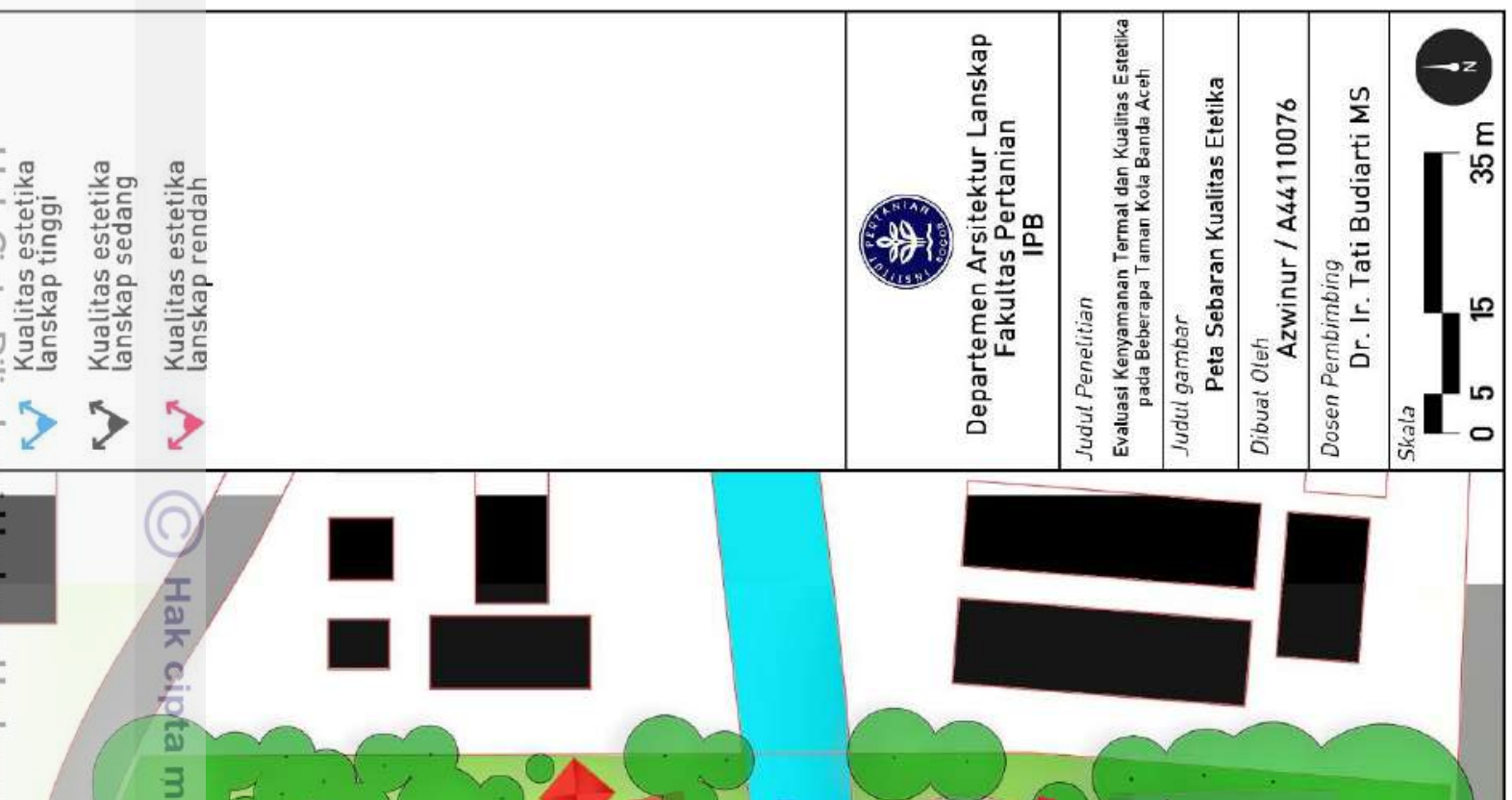

웅

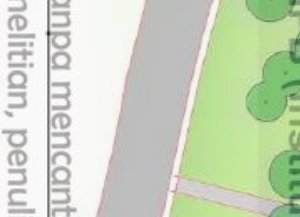

ब洅

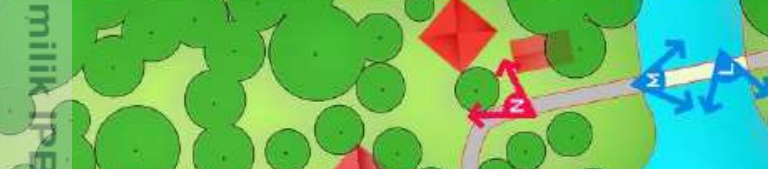

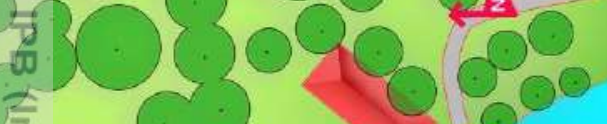
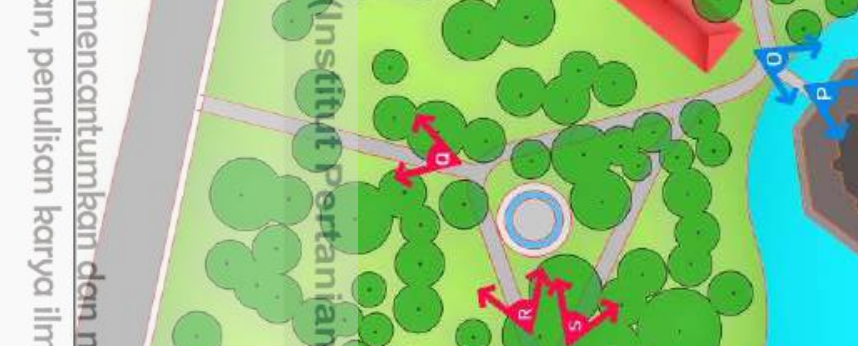

总施

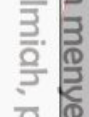

갈

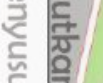

ํํㄹ

$\rightarrow$ Ta 0 ?
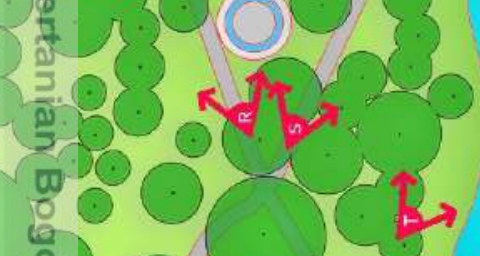

(혹)
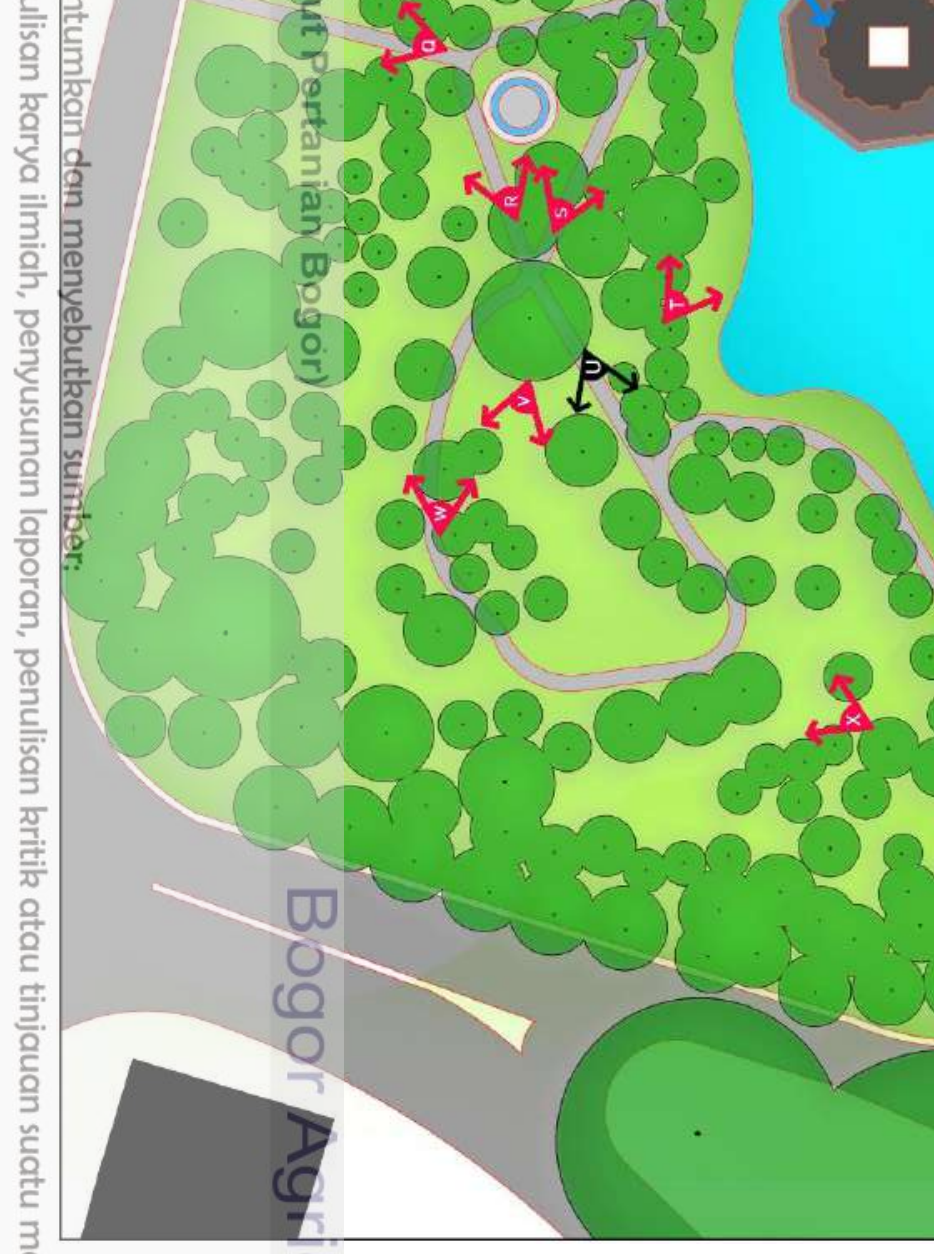


\section{Lapangan Blang Padang}

Hasil penilaian estetika lanskap di LBP dapat dilihat pada grafik di bawah ini

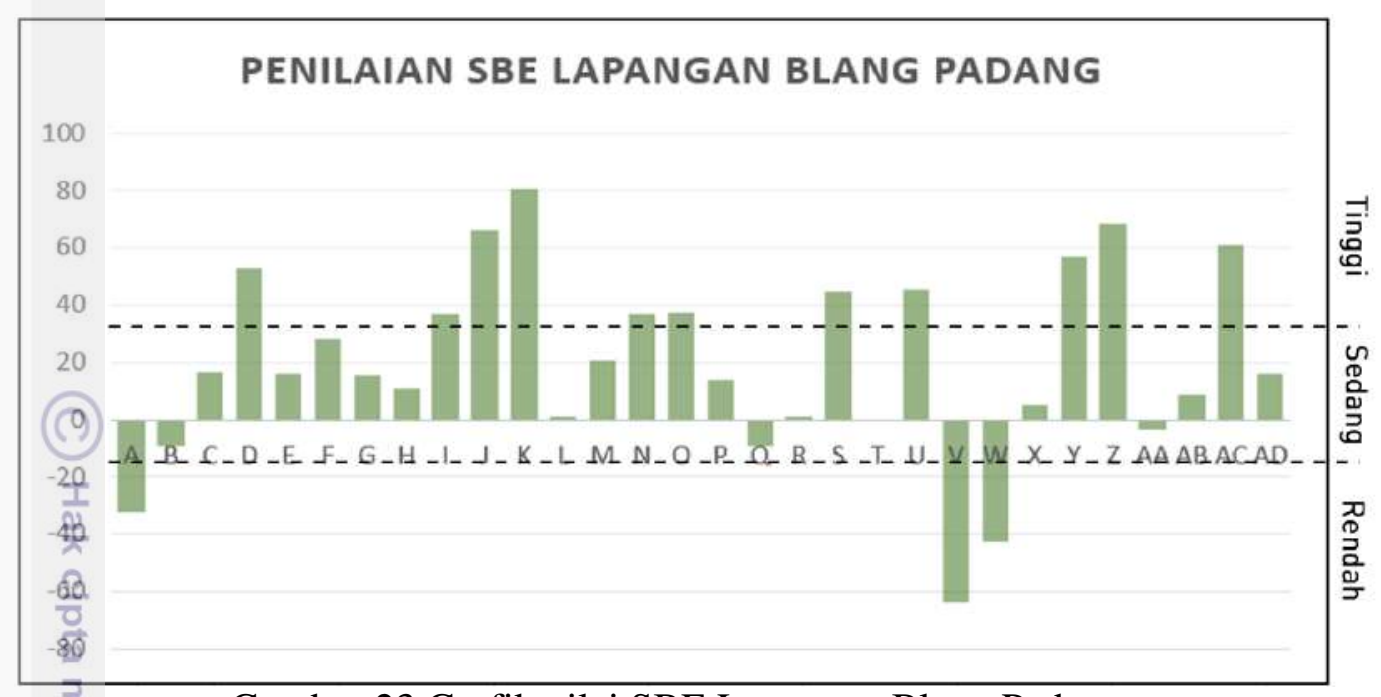

Gambar 23 Grafik nilai SBE Lapangan Blang Padang

Grafik di atas menunjukkan bahwa lanskap $\mathrm{K}$ adalah lanskap yang mempunyai nilai estetika tertinggi dengan nilai SBE 80.5. Pada lanskap K terdapat penataan yang rapi dan bersih. Hal itu diaplikasikan pada penataan pohon-pohon angsana yang diletakkan sejajar pada bagian sisi kiri dan kanan jalan yang berfungsi sebägai tanaman pengarah dan peneduh. Sementara itu, lanskap yang mempunyai nilai terendah adalah lanskap V dengan nilai SBE -63.7. Pada lanskap V terdapat penataan elemen lanskap yang kurang rapi. Hal itu ditunjukkan dari adanya vegetasi dan rumput yang tumbuh tidak merata sehingga secara visual terlihat kurang rapi, dan ferdapat sampah serta bangunan liar di dalamnya. Berdasarkan hasil penelitian Ruswan (2006), nilai estetika dapat ditingkatkan bila lanskap memiliki kerapihan yang baik dan lingkungan yang bersih dari sampah.

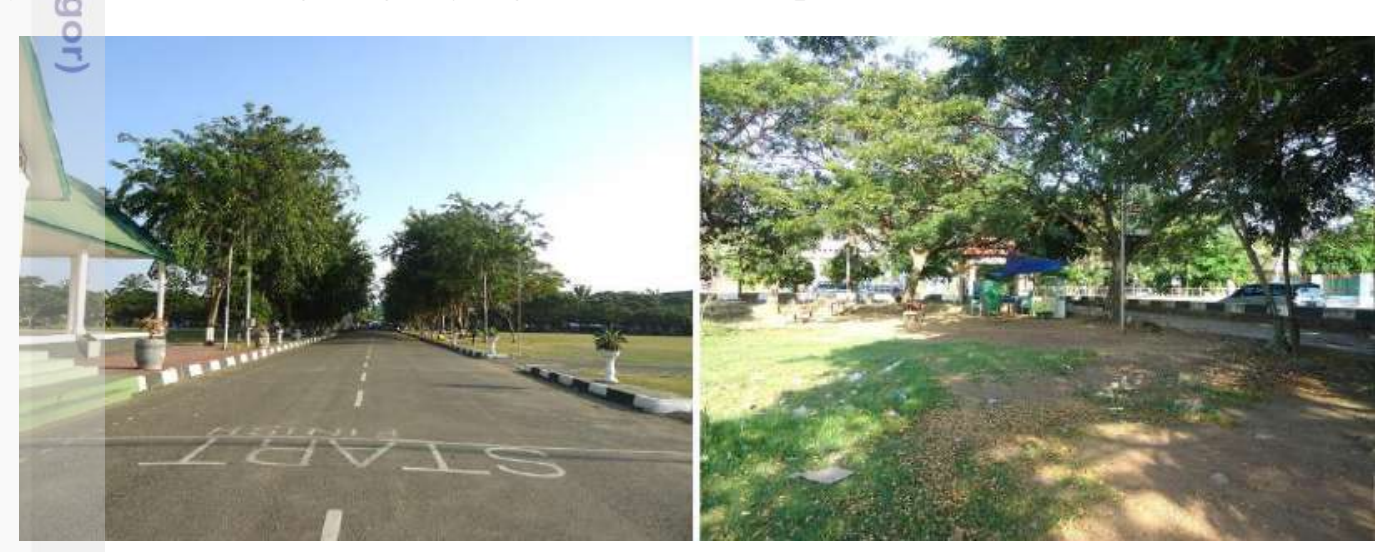

Gambar 24 Lanskap K dengan nilai SBE tertinggi (kiri), Lanskap V dengan nilai SBE terendah (kanan)

Secara keseluruhan lapangan ini belum mempunyai pengelolaan yang optimal dan merata. Lapangan ini sejak awal tidak pernah didesain dan dipersiapkan untuk segala fungsi kegiatan, namun segala fasililitas yang ada saat ini terbangun secara tidak konsisten dan tidak ada keterpaduan secara menyeluruh. Hal ini menjadikan jumlah lanskap pada nilai SBE sedang lebih banyak dibandingkan nilai SBE tinggi. 


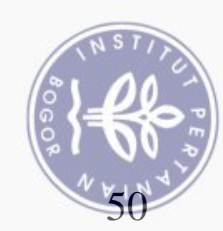

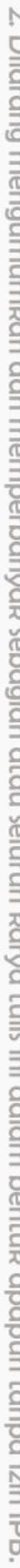

Tabel 22 Kategori kualitas estetika lanskap Lapangan Blang Padang

을

害 흥

I No

Rendah

Kategori Kualitas Estetika Lanskap

응 을 흥 궁

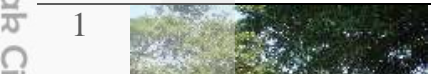

C.

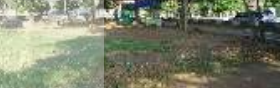

离 을

은 흘 을

을 융 율

疍

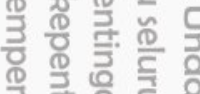

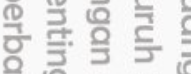

등일 일

을 을 을

을 을 을

SBE

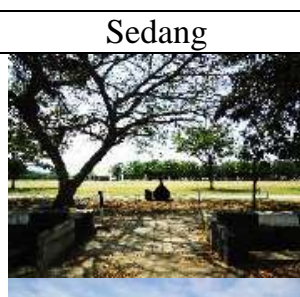

(W)
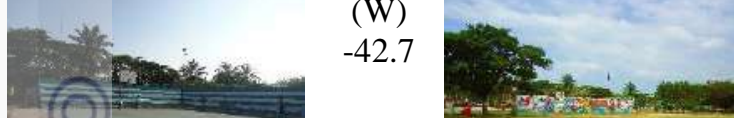

SBE

$-63.7$

(B)

$-9.3$

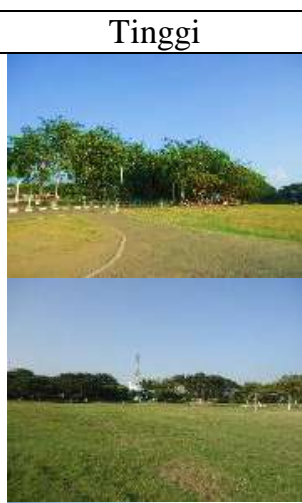

SBE

36.7
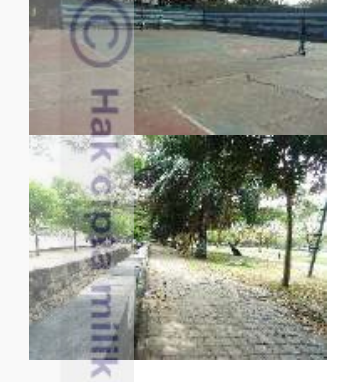

(A)
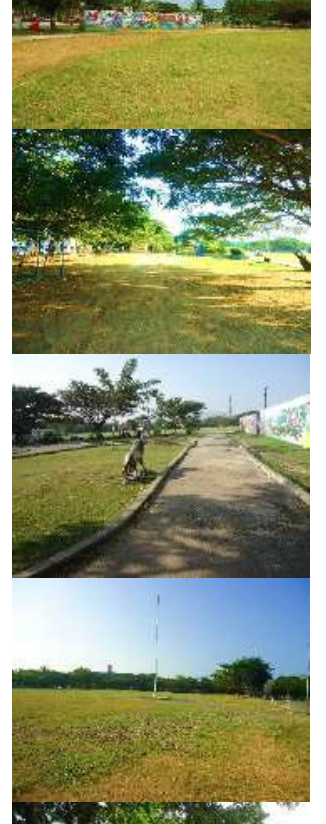

(L)

(AA)

(O)

$-32.5$

$-3.2$

37.3

(N)

36.8

(T)

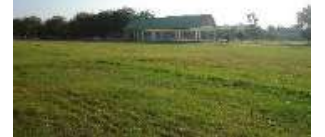

0.0

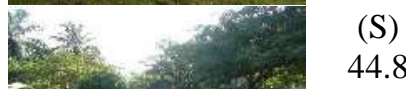

0.8

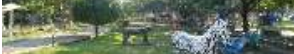

44.8

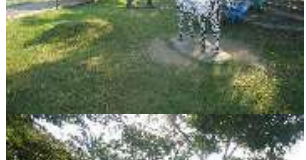

(U)

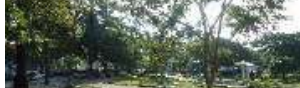

45.6

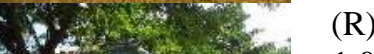

(R)
1.0

Not $-5,5$

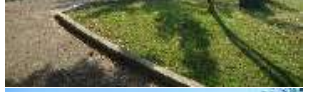

(D)
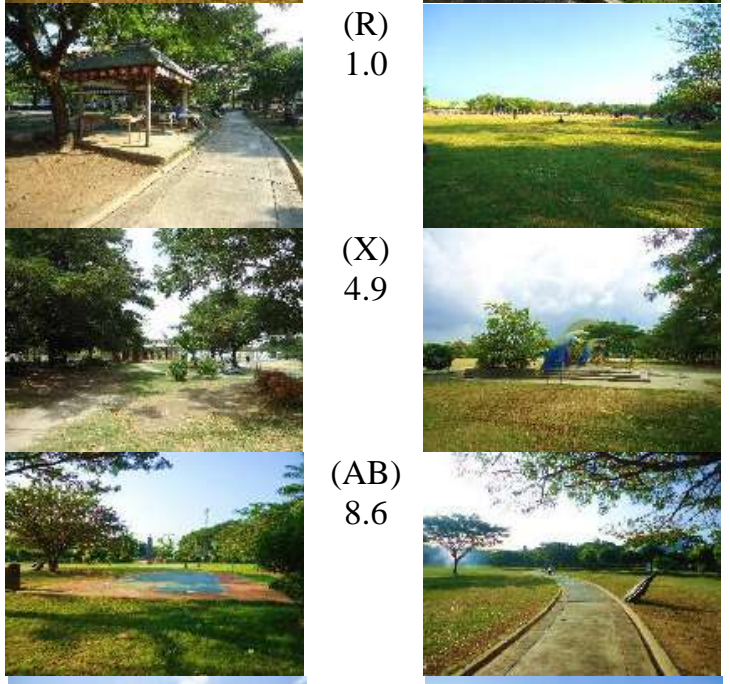

52.7

(X)

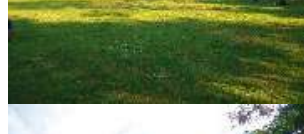

(Y)

4.9

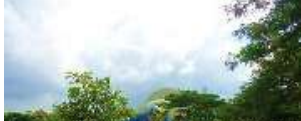

56.6

(AB)

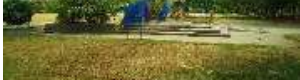

8.6

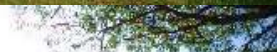

(AC)

61.1

(H)

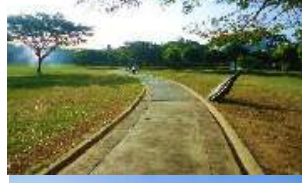

11.1

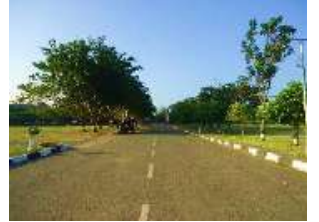

(J)

66.0 


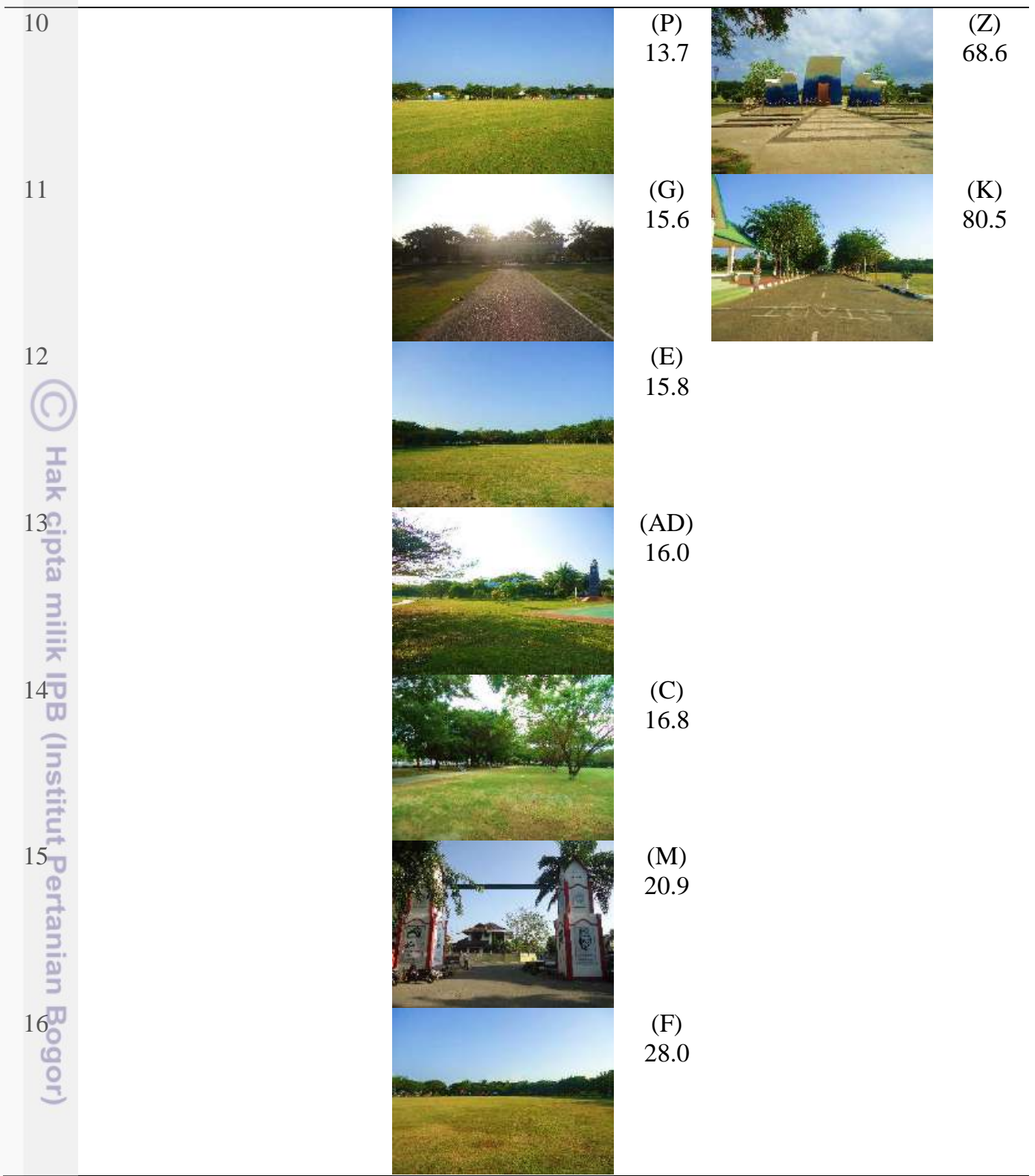

Tabel 22 memperlihatkan bahwa lanskap yang tergolong ke dalam nilai SBE tinggi didominasi oleh lanskap yang menerapkan prinsip desain kesatuan, serta irama dan pengulangan pada penataan vegetasi dan perkerasan berupa jalan. Prinsip desain tersebut dapat menciptakan suatu keharmonisan antara elemennya dan mampu mengantarkan arah pandangan pengamat pada focal point. Sementara itu, pada lanskap yang tergolong ke dalam kelompok nilai SBE rendah mempunyai karakter yang tidak rapi dan tidak bersih. Hal tersebut ditunjukkan dari adanya sampah dedaunan kering dan tidak meratanya penutupan vegetasi rumput yang terdapat pada lanskap A, W, dan V. Lapangan Blang Padang didominasi oleh nilai estetika sedang yang menyebar hampir di semua titik pada lapangan tersebut. Estetika tinggi terdapat pada welcome area, area playground, hamparan rumput, dan jalan yang membelah lapangan kiri kanan. Gambar sebaran foto dan klasifikasi kualitas visual disajikan pada Gambar 25. 


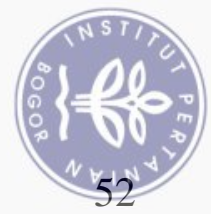

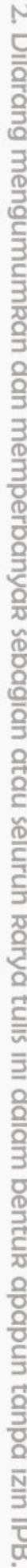

产

运

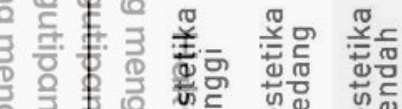

응

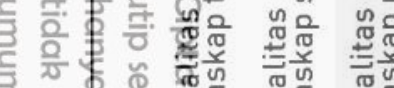

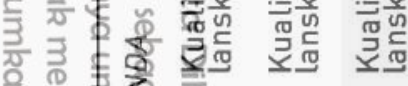

道专焉

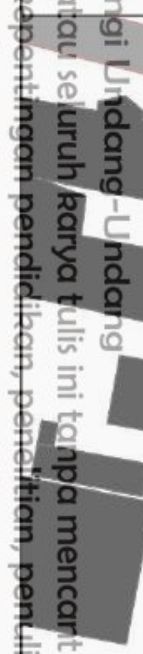

霍焉

20일

表每

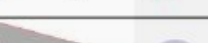

$+0$
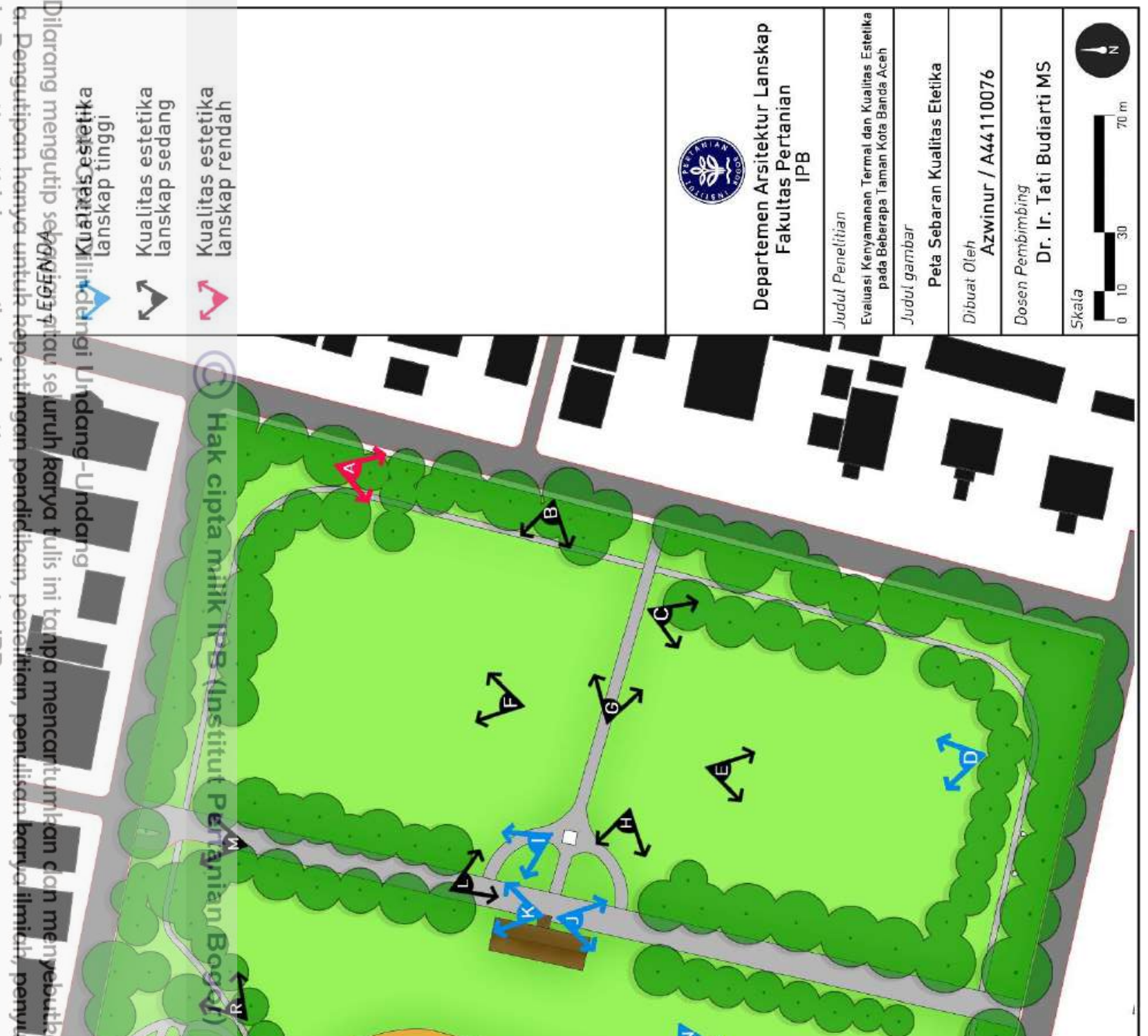

ำ

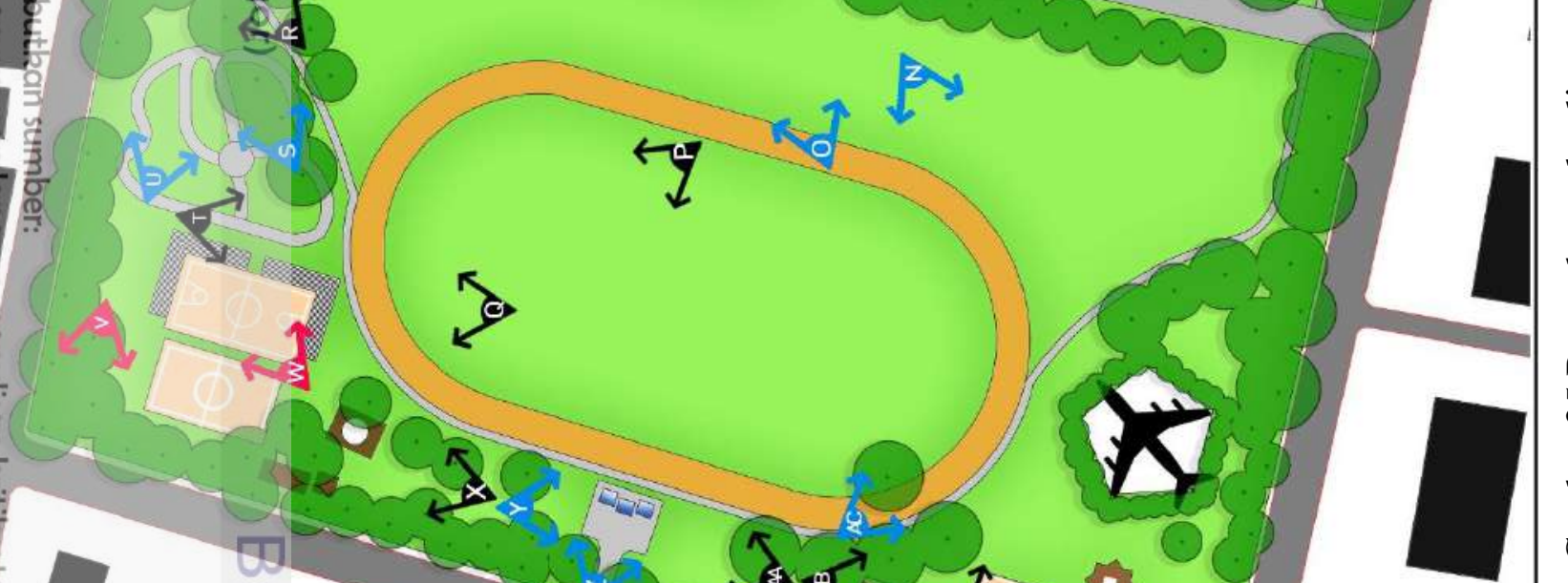
$x_{x \rightarrow 1}^{-1}$

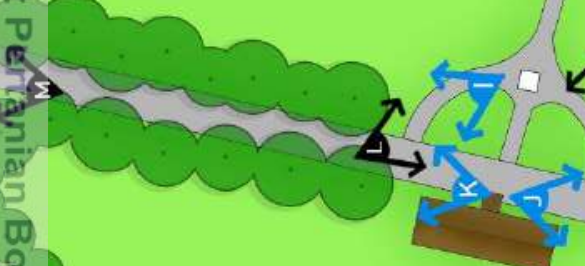

s. 


\section{Hutan Kota BNI}

Hasil penilaian responden terhadap lanskap pada Hutan Kota BNI menghasilkan nilai SBE paling tinggi sebesar 100.0 dan nilai paling rendah sebesar -50.4. Grafik nilai SBE keseluruhan pada lanskap di Hutan Kota BNI disajikan pada Gambar 26.

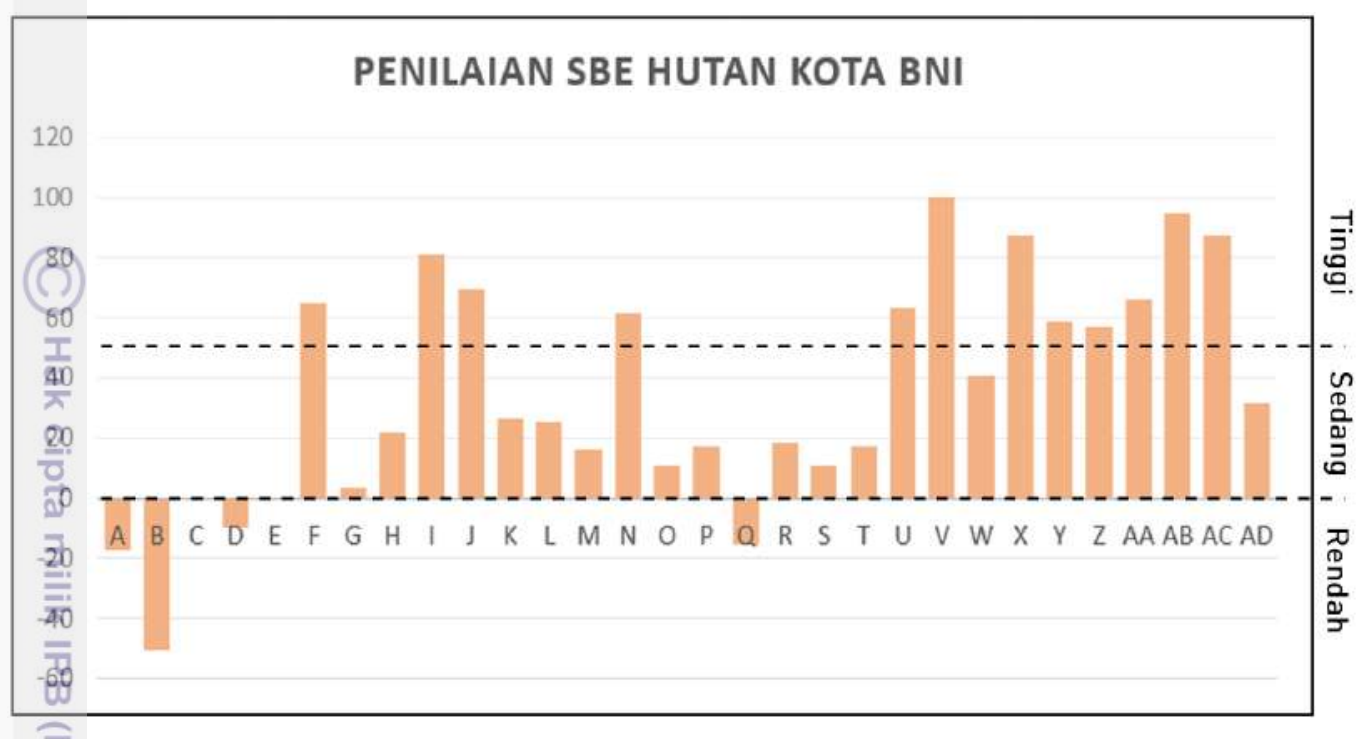

\section{Gambar 26 Grafik nilai SBE Hutan Kota BNI}

Gambar 26 menunjukkan bahwa lanskap yang tergolong ke dalam nilai SBE tinggi terdiri atas 12 lanskap, yaitu lanskap Z, Y, N, U, F, AA, J, I, AC, X, AB, dan V. Lanskap yang termasuk ke dalam nilai SBE sedang berjumlah sebanyak 14 lanskap, yaitu lanskap C, E, G, O, S, M, P, T, R, H, L, K, AD, dan W. Sementara itu, Janskap yang termasuk ke dalam nilai SBE rendah yaitu lanskap A, B, D, dan Q. Lanskap yang memiliki nilai SBE paling tinggi adalah lanskap V, sedangkan lanskap yang mempunyai nilai SBE paling rendah adalah lanskap B. Foto lanskap yang mempunyai nilai paling tinggi dan paling rendah di SBE disajikan pada Gambar 27.

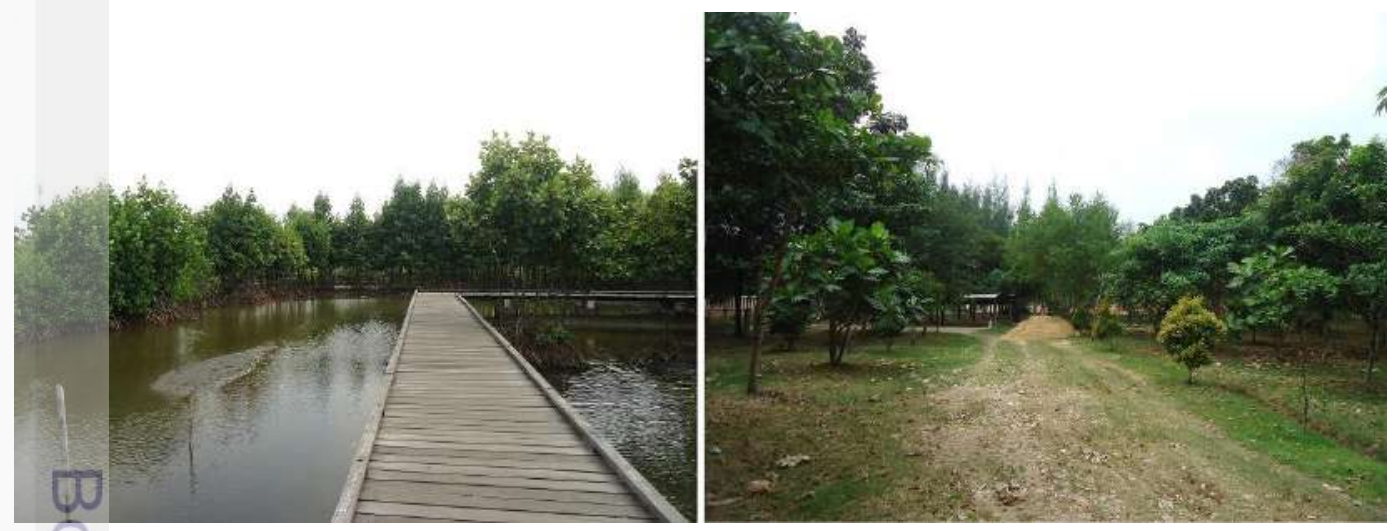

Gambar 27 Lanskap V dengan nilai SBE tertinggi (kiri), Lanskap B dengan nilai SBE terendah (kanan)

Lanskap V yang memiliki nilai SBE paling tinggi memiliki perpaduan elemen air, perkerasan, dan vegetasi. Tegakan pohon yang disusun secara berulang yang 
digunakan sebagai background pemandangan dapat menciptakan suatu lanskap yang harmonis dan dapat meningkatkan kualitas estetika. Selain itu, terdapat perpaduan antara elemen air dan elemen keras berupa deck yang dipercaya dapat I meningkatkan nilai keindahan. Sementara itu, pada lanskap B yang merupakan lanskap dengan nilai paling rendah terlihat kurang tersedianya fasilitas pada jalur - pejalan kaki. Hal ini ditunjukkan dari material yang digunakan pada jalur sirkulasi pejalan kaki berupa tanah yang dapat membuat kualitas estetika menjadi rendah. Selain itu, kerapihan pada penataan pohon dan penutupan rumput yang tumbuh belum merata menjadi faktor yang dapat menyebabkan rendahnya nilai estetika pada lanskap B. Kategori kualitas estetika seluruh lanskap yang terdapat di Hutan Kota BNI disajikan pada Tabel 23.

Tabel 23 Kategori kualitas estetika lanskap Hutan Kota BNI Kategori Kualitas Estetika Lanskap

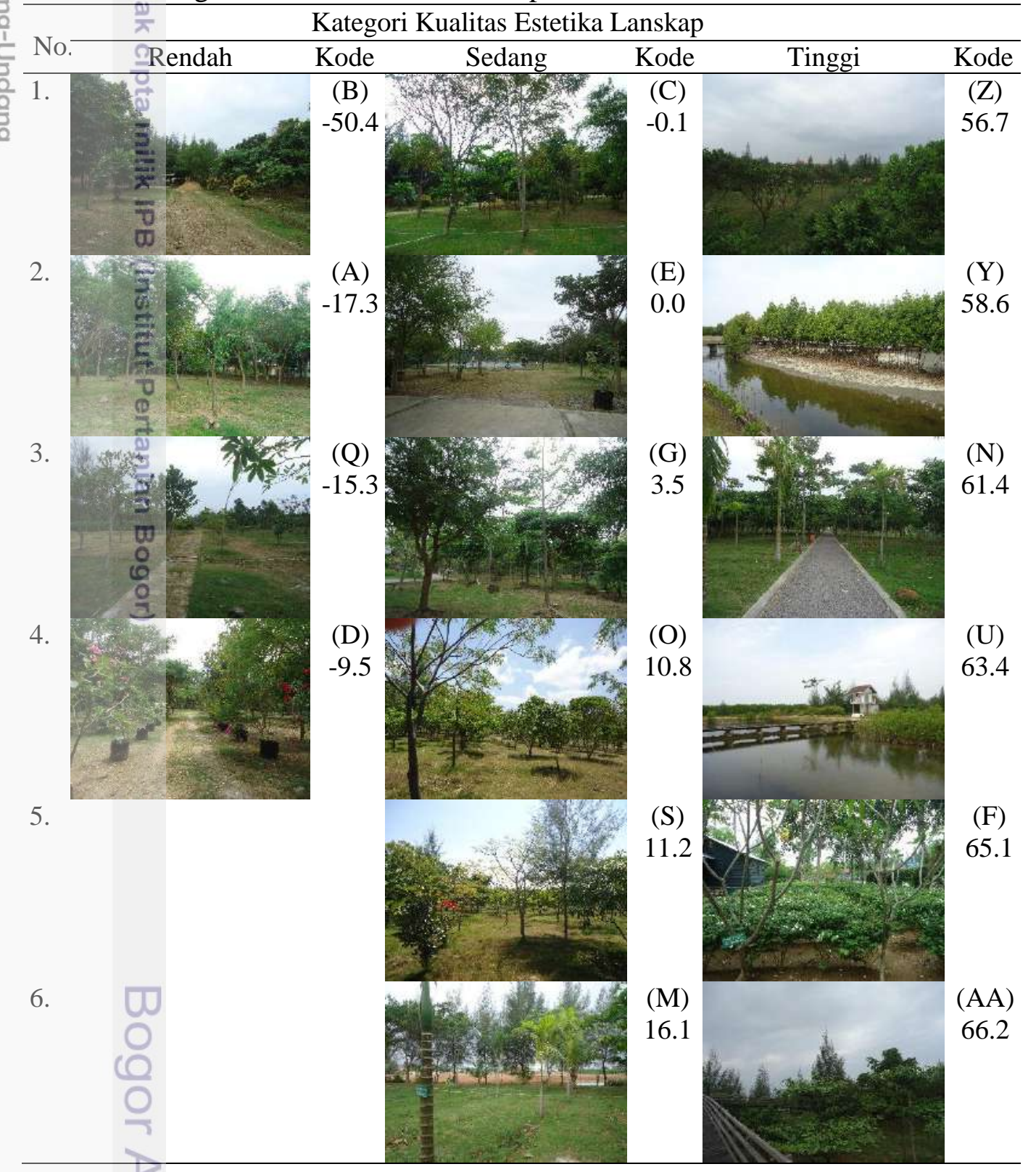




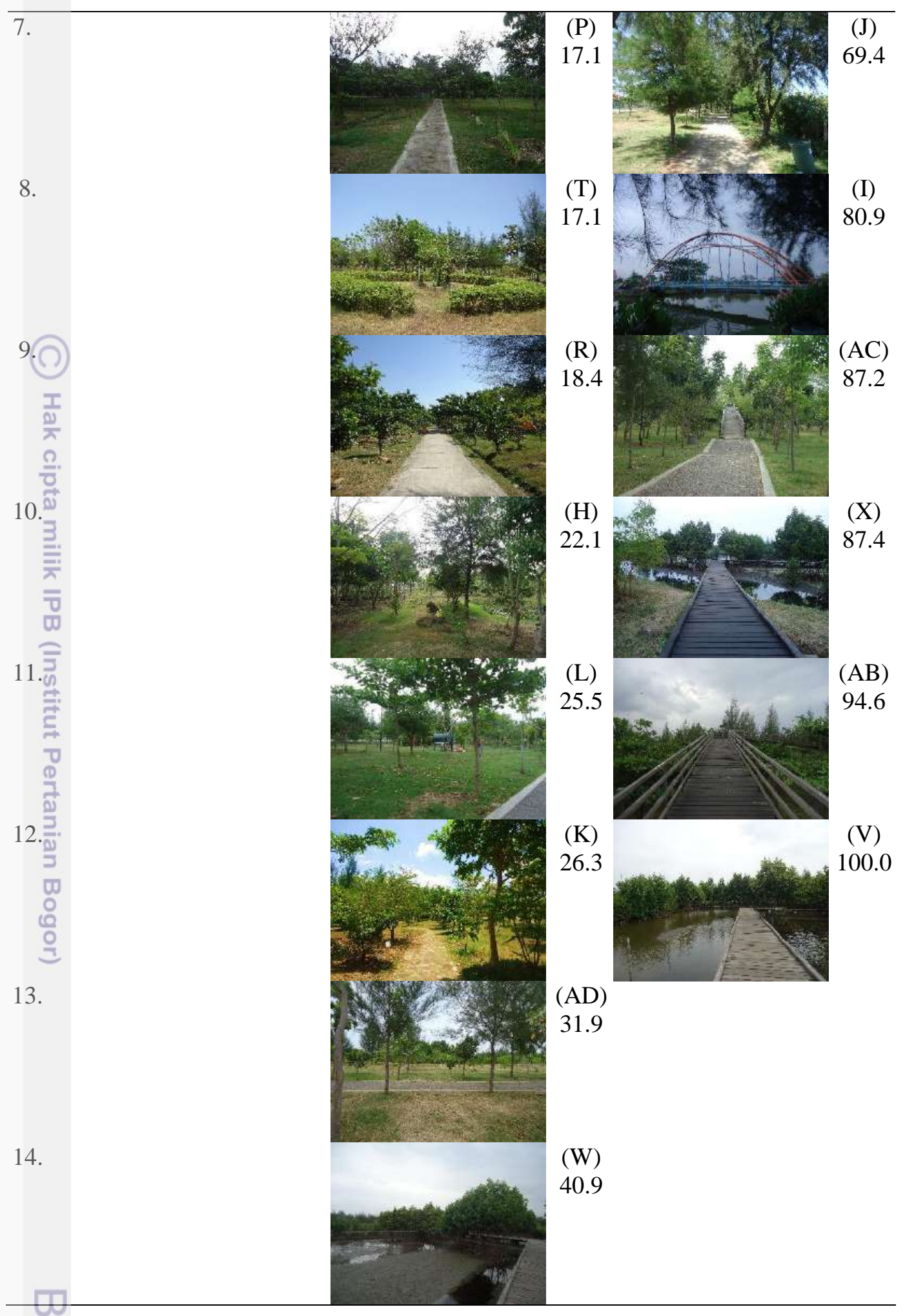

Tabel 23 menunjukkan bahwa lanskap yang mempunyai nilai estetika tinggi terdapat pada lanskap yang memadukan tiga elemen lanskap berupa elemen lunak seperti vegetasi dan air dengan elemen keras berupa jalur sirkulasi (jalan, jembatan, dan deck), serta penataan elemen lanskap yang rapi. Hal ini diperlihatkan dari lanskap yang menggunakan ketiga elemen tersebut hanya tergolong ke dalam nilai 


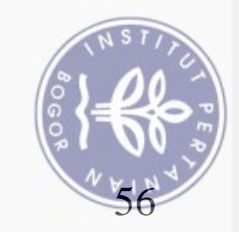

SBE tinggi dengan nilai tertinggi pada lanskap V yang menggunakan ketiga elemen lanskap tersebut. Lanskap estetika tinggi menyebar hampir dominan di area utara, dekat dengan badan air dalam hutan kota. Area utara dominan memperlihatkan $\frac{T}{2}$ keseluruhan pemandangan lanskap dari arah pandang jalur jembatan deck. Lanskap yang dinikmati di atas deck memberikan sensasi yang berbeda yang mampu meminjamkan kualitas lanskap ke arah luar dari hutan, pemandangan terlihat seperti lanskap pantai dan tambak yang ada di sekitar hutan. Lanskap tinggi juga memperlihatkan axis dari lanskap dalam hutan yang membelah sisi tegakan pohon kiri dan kanan terhadap jalan pedestrian yang membelah dua sisi tersebut. Axis tersebut menciptakan keseimbangan visual (visual balance) melalui komposisi dari segi bentuk, bobot, dan warna yang baik.

Lanskap yang mempunyai nilai estetika sedang dan estetika rendah terdiri atas lanskap yang mempunyai penutupan vegetasi rumput yang tidak merata. Arsitektural tajuk dari pohon-pohon terlihat tumbuh tidak sesuai dengan harapan. Pohon lebih banyak yang layu dan gersang. Hal ini mengakibatkan lanskap terlihat tidak rapidan gersang. Secara keseluruhan, lanskap yang terdapat pada Hutan Kota BNI dipengaruhi oleh adanya elemen air dan penutupan vegetasi rumput yang rapi. Banyaknya lanskap yang mempunyai vegetasi rumput dengan penutupan yang tidak merata mênyebabkan lanskap yang terdapat di Hutan Kota BNI memiliki nilai SBE sedang lebih dominan daripada nilai SBE tinggi.

Persentase kualitas estetika pada Hutan Kota BNI terdiri atas $40 \%$ foto lanskap yang termasuk ke dalam kategori nilai SBE tinggi, $47 \%$ foto lanskap yang termasuk ke dalam kategori nilai SBE sedang, dan $13 \%$ foto lanskap yang termasuk ke dalam kategori nilai SBE rendah. Lanskap yang mempunyai nilai estetika sedang terdapat pada seluruh area hutan. Estetika sedang juga tidak memperlihatkan objek yang ingin diperlihatkan, lebih dominan hanya tegakan-tegakan pepohonan saja. Estetika rendah menyebar di bagian selatan dari hutan berdekatan dengan pintu masuk dü. Wilayah ini belum memiliki pedestrian yang layak sehingga faktor fasilitas juga membuat kualitas lanskap di area ini menjadi rendah. Sedangkan estetika tinggi lebih dominan pada area deck, hutan mangrove, dan air. Peta sebaran kualitas estetika pada Hutan Kota BNI disajikan pada Gambar 28. 


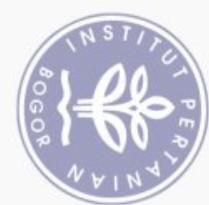

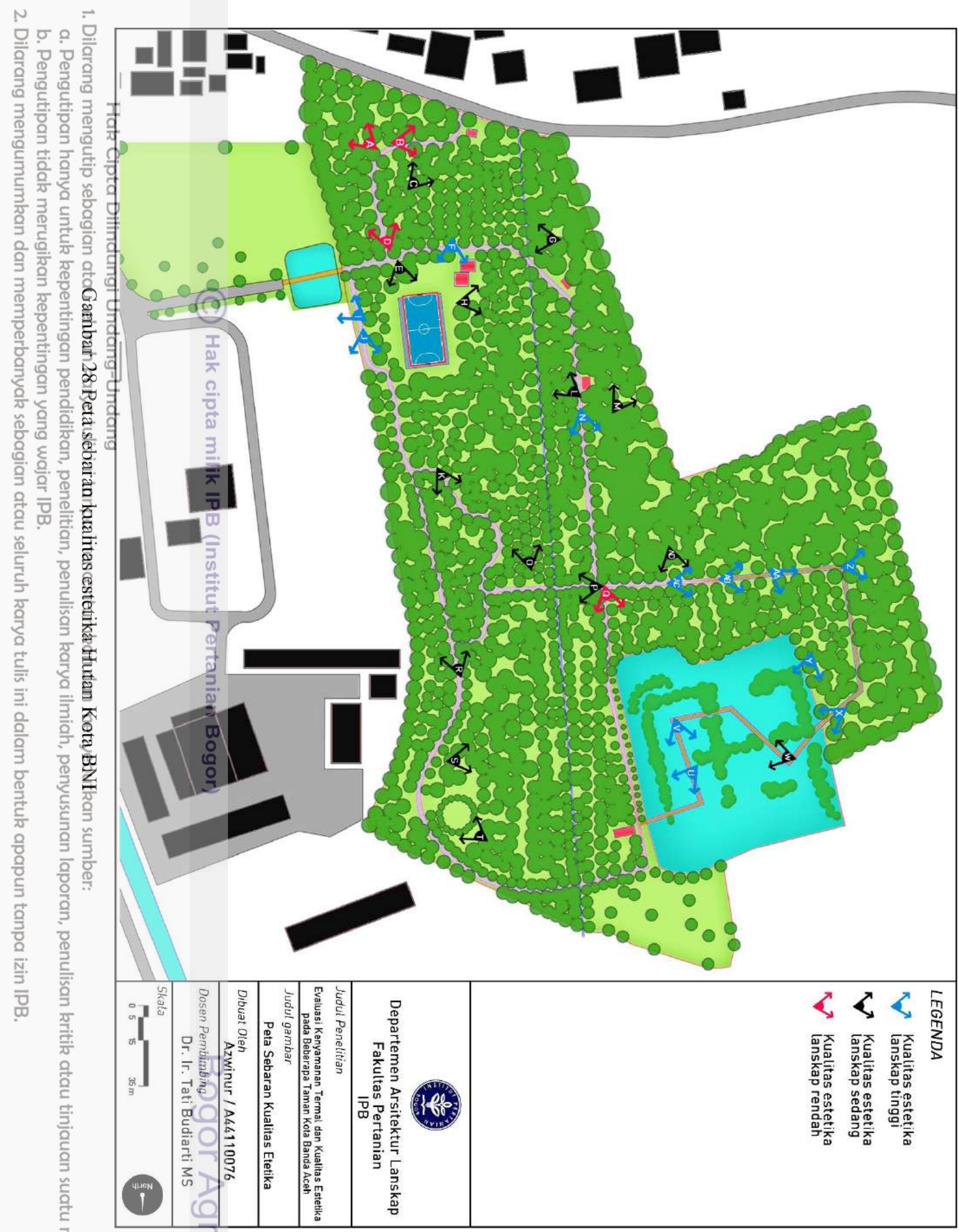




\section{Persepsi dan Preferensi Pengunjung}

Berdasarkan penyebaran kuesioner kepada pengunjung pada masing-masing T lokasi penelitian didapatkan 90 orang responden. Jumlah tersebut sekiranya dapat mewakili seluruh pengunjung di ketiga lokasi penelitian. Hasil analisis dari ofuesioner ini berupa data mengenai karakteristik responden, persepsi, dan $\div$ preferensi responden mengenai estetika dan kenyamanan di masing-masing lokasi penelitian. Persepsi responden yang berasal dari pengunjung taman sangat diperlukan dalam penelitian ini karena menjadi unsur utama dalam pengelolaan, perbaikan, dan pengembangan taman kota, sehingga perlu adanya kesamaan = persepsi untuk pembangunan di massa yang akan datang agar dapat menciptakan RTH (taman kota) yang berkelanjutan.

\section{Karakteristik Responden}

Karakteristik yang diamati terdiri atas jenis kelamin, umur, pendidikan, profesi, dan tujuan kunjungan. Karakteristik tersebut dapat menggambarkan perilaku pengguna serta pengetahuan masyarakat terhadap penggunaan taman kota. Berikut adalah grafik karakteristik pengunjung di tiga lokasi taman kota.
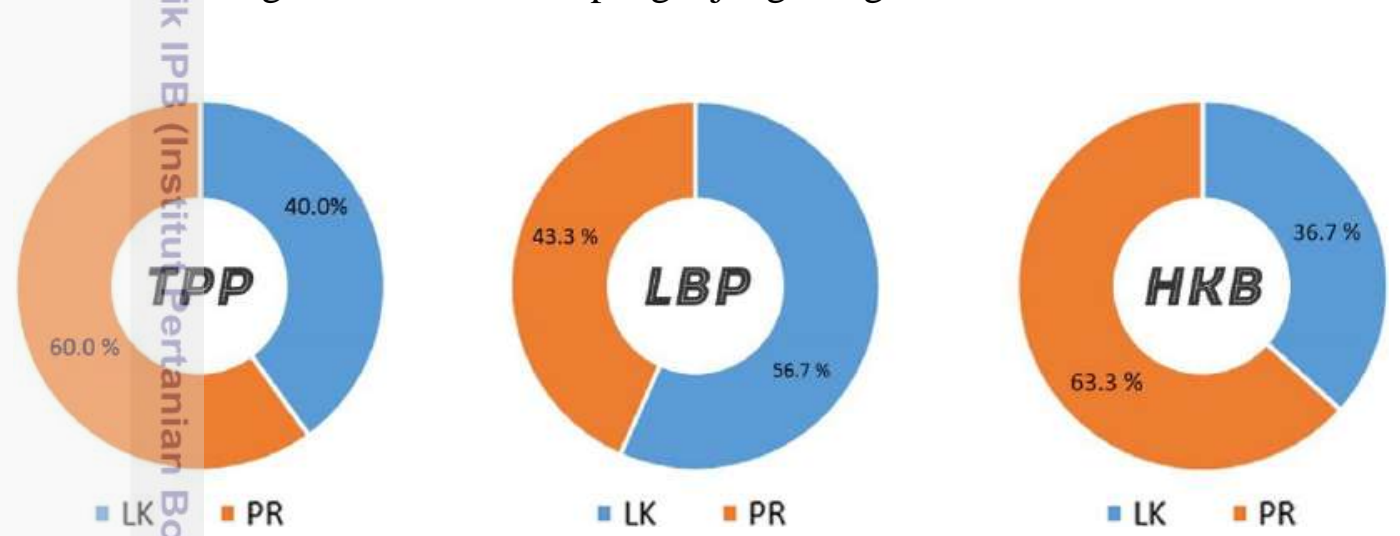

Gambar 29 Grafik persentase jenis kelamin responden di Taman Putroe Phang,

$\exists$ Lapangan Blang Padang, dan Hutan Kota BNI
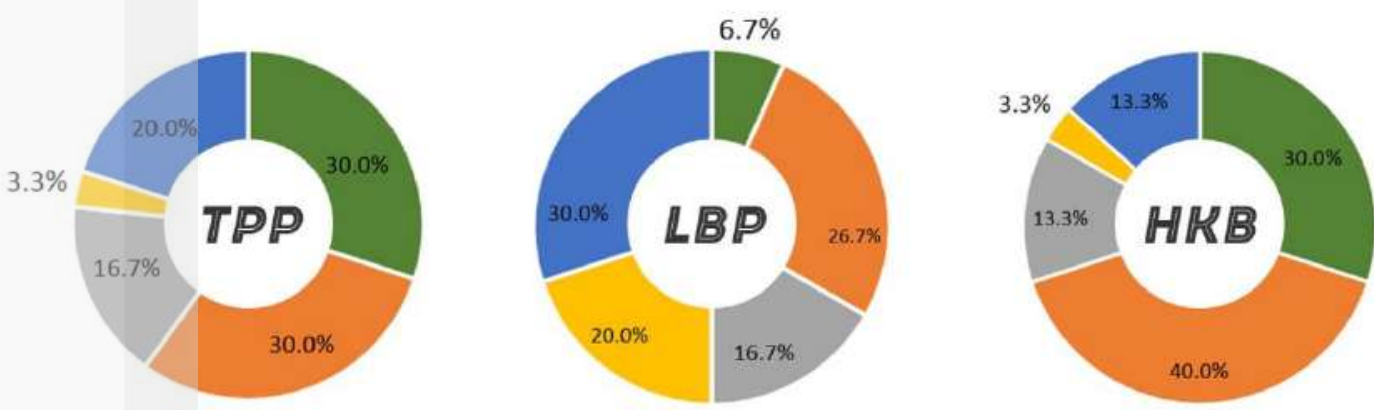

00 - 0 PELAIAR MAHASISWA

Gambar 30 Grafik persentase profesi responden di Taman Putroe Phang, Lapangan Blang Padang, dan Hutan Kota BNI 


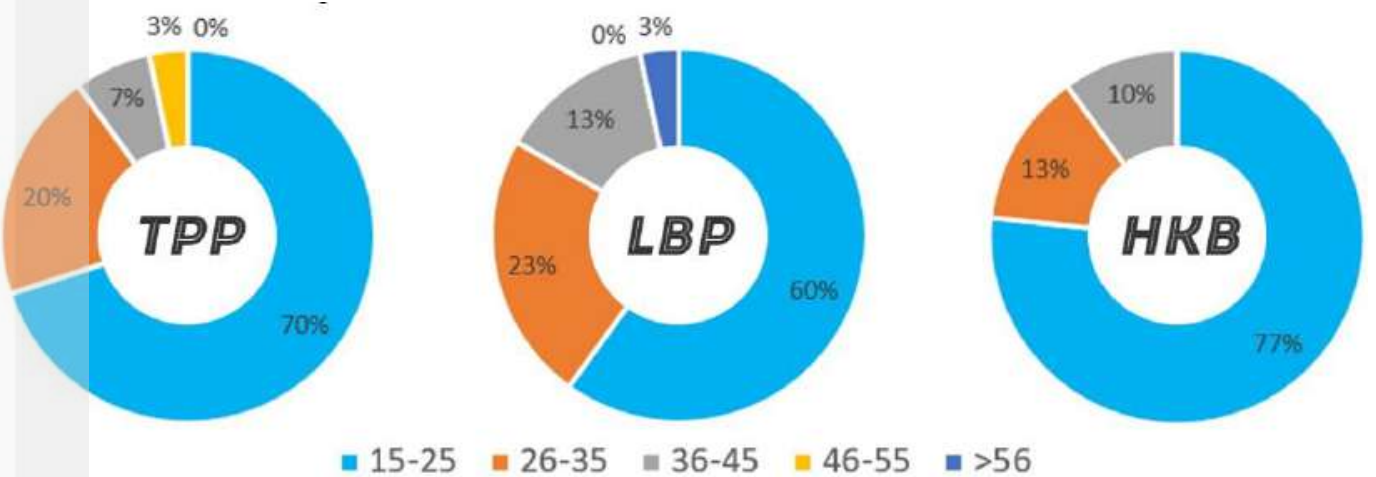

Gambar 31 Grafik persentase umur responden di Taman Putroe Phang, Lapangan Blang Padang, dan Hutan Kota BNI

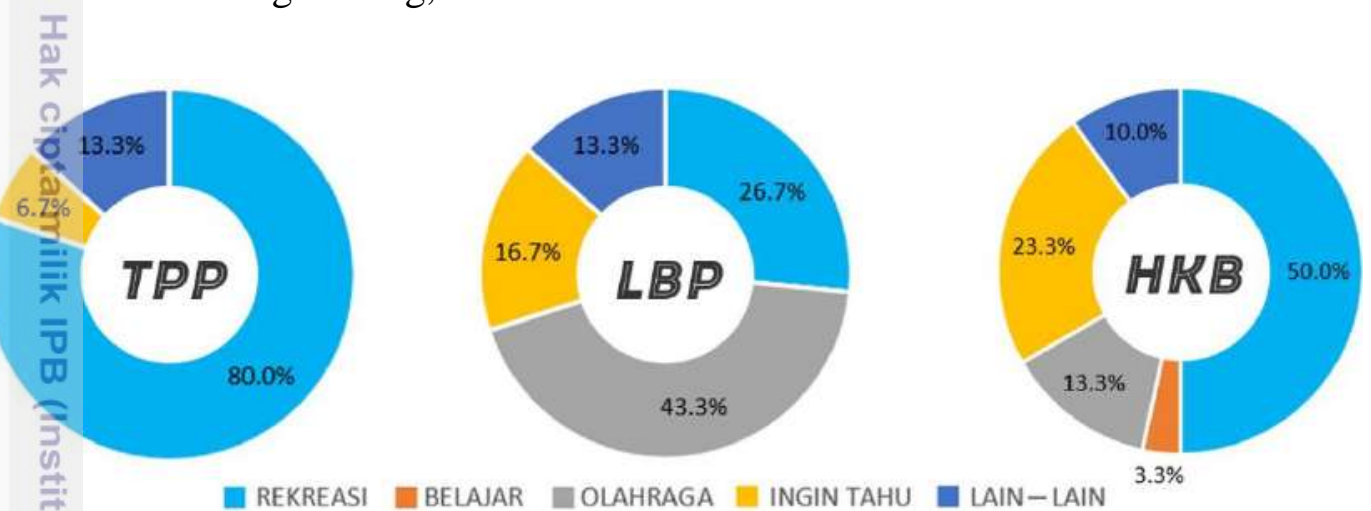

Gambar 32 Grafik persentase tujuan responden di Taman Putroe Phang, Lapangan

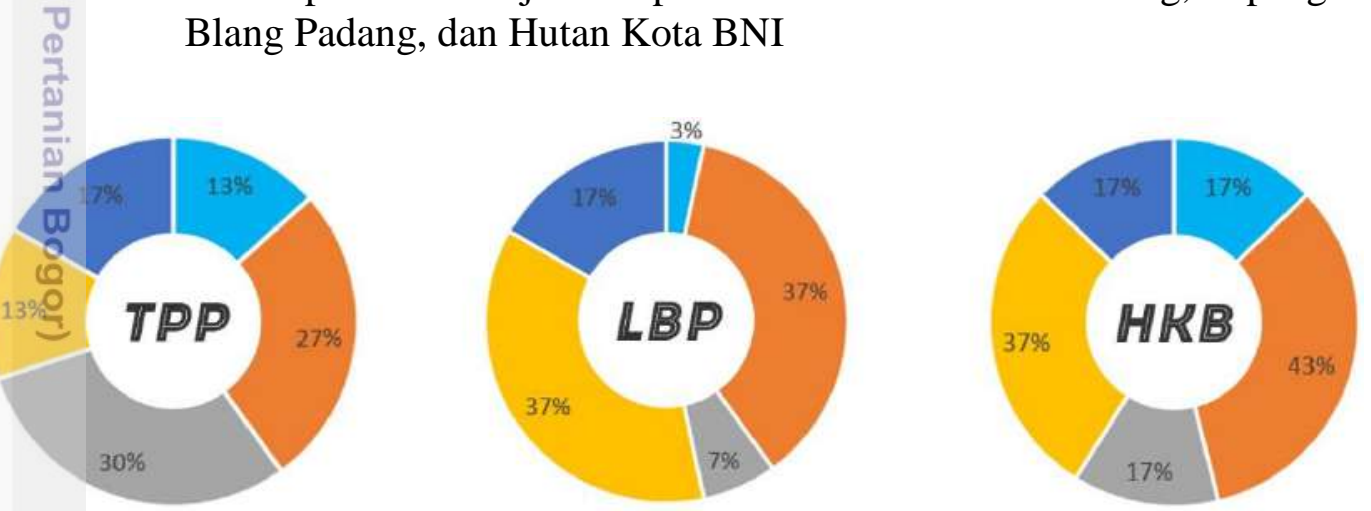

$=<500 \mathrm{~m}=500 \mathrm{~m}-3 \mathrm{~km}=3 \mathrm{~km}-5 \mathrm{~km}=5 \mathrm{~km}-10 \mathrm{~km}=>10 \mathrm{~km}$

Gambar 33 Grafik jarak tempat tinggal responden terhadap Taman Putroe Phang, Lapangan Blang Padang, dan Hutan Kota BNI

Pada grafik karakteristik pengunjung di atas dapat dilihat bahwa pengunjung pada ketiga lokasi penelitian didominasi oleh pelajar dan mahasiswa yang berumur 15 sampai 25 tahun dengan frekuensi kunjungan yang tidak tentu. Karakteristik jenis kelamin pada lokasi Taman Putroe Phang dan Hutan Kota BNI didominasi oleh perempuan, sedangkan pada lokasi penelitian di Lapangan Blang Padang didominasi oleh laki-laki. 


\section{Persepsi Responden}

Persepsi merupakan tanggapan (penerimaan) langsung dari suatu keadaan melalui panca indranya mengenai keadaan taman kota saat itu. Hasil data yang T didapat berupa persepsi pengunjung mengenai penataan, kebersihan, kenyamanan suhu udara, dan kelembapan udara yang terdapat di setiap lokasi penelitian. Pilihan - jawaban pada kuesioner yaitu sangat buruk, buruk, sedang, baik, dan sangat baik, 5 namun disesuaikan pula dengan jenis pertanyaannya.

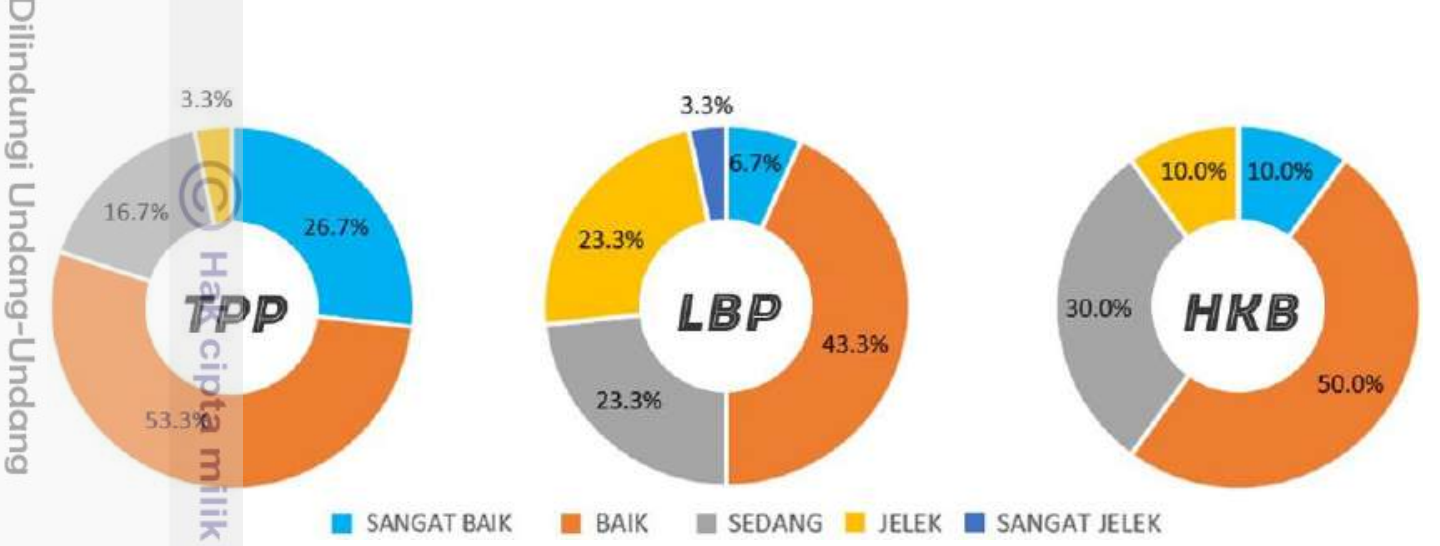

Gambar 34 Grafik persepsi responden terhadap penataan di Taman Putroe Phang, Lapangan Blang Padang, dan Hutan Kota BNI

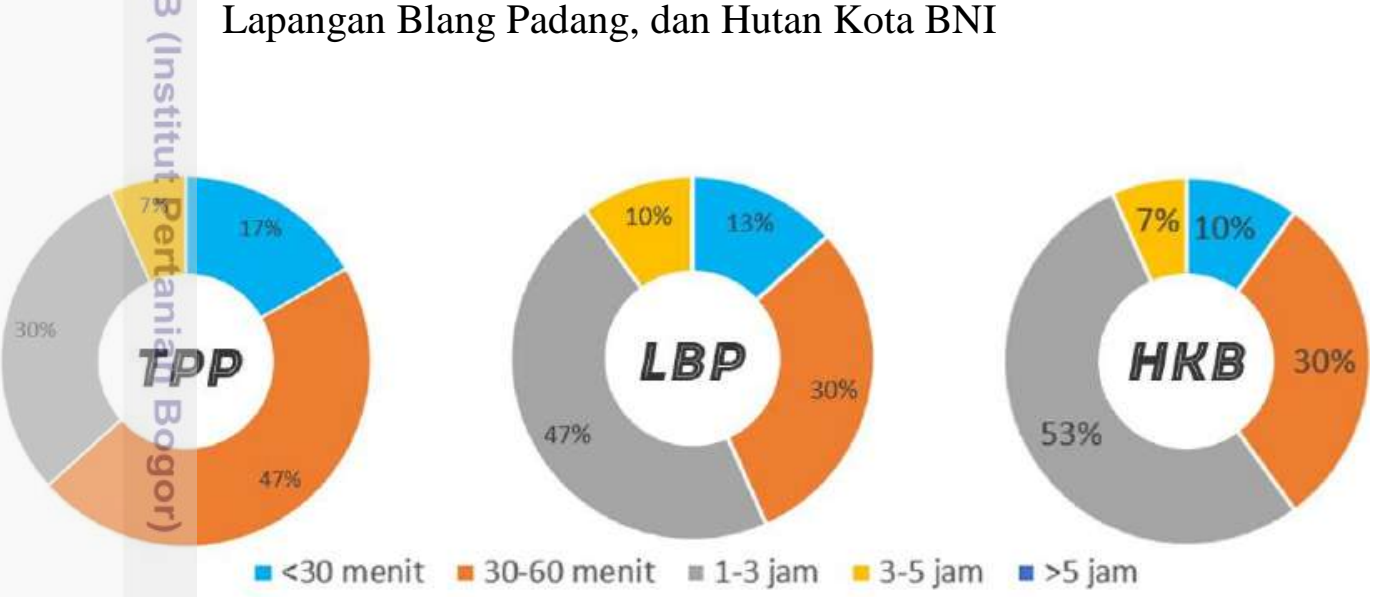

Gambar 35 Grafik lamanya kunjungan responden di Taman Putroe Phang, Lapangan Blang Padang, dan Hutan Kota BNI
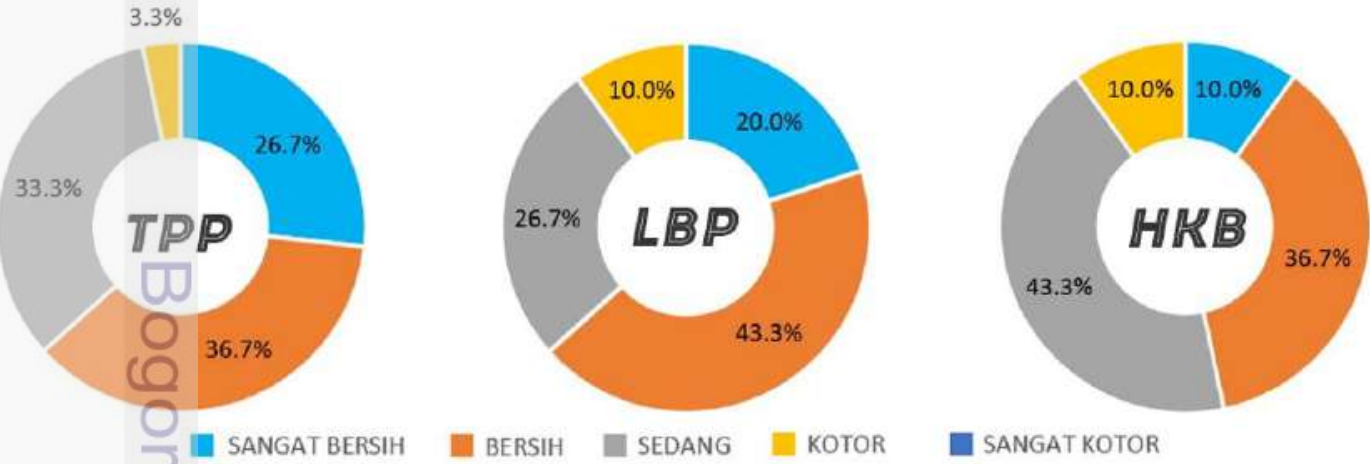

Gambar 36 Grafik persepsi responden terhadap kebersihan di Taman Putroe Phang, Lapangan Blang Padang, dan Hutan Kota BNI 


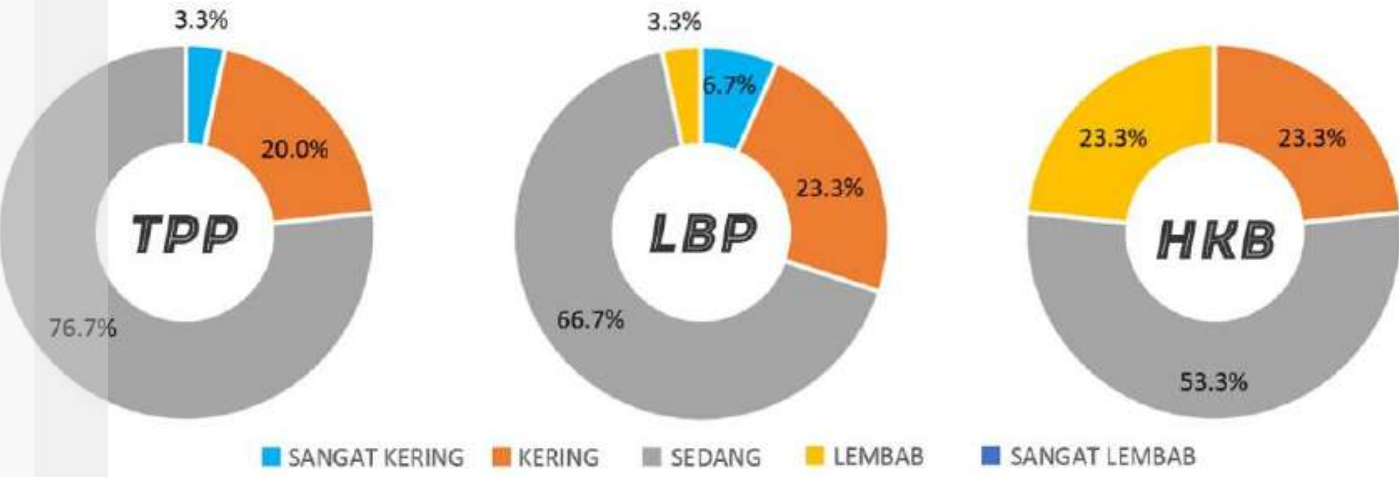

Gambar 37 Grafik persepsi responden terhadap kelembapan di Taman Putroe Phang, Lapangan Blang Padang, dan Hutan Kota BNI

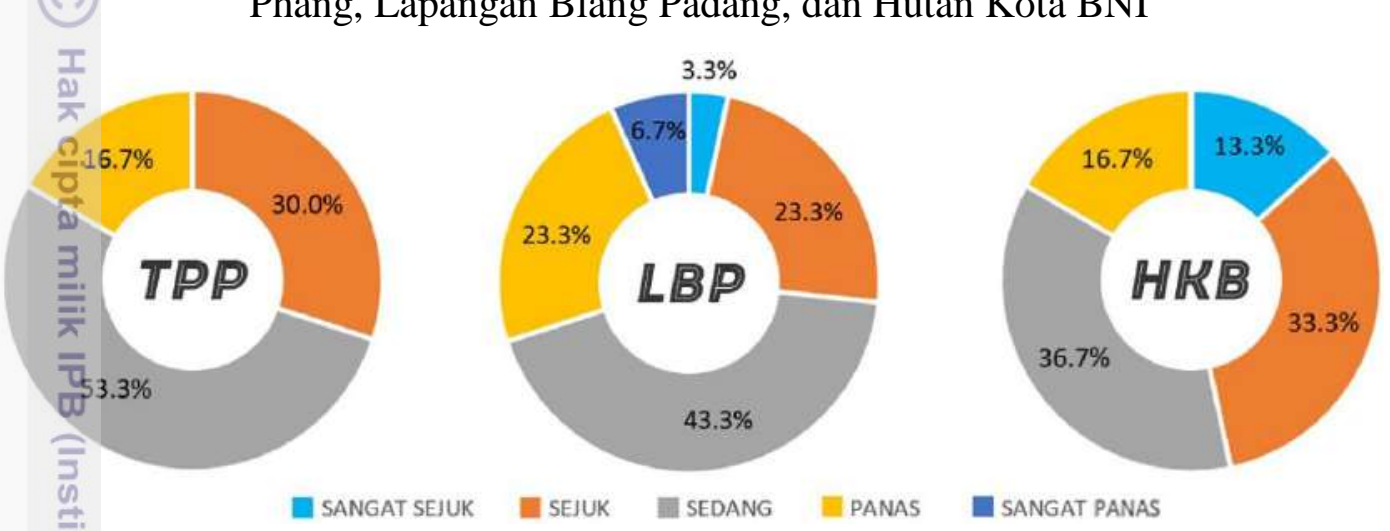

Gambar 38 Grafik persepsi responden terhadap suhu di Taman Putroe Phang,

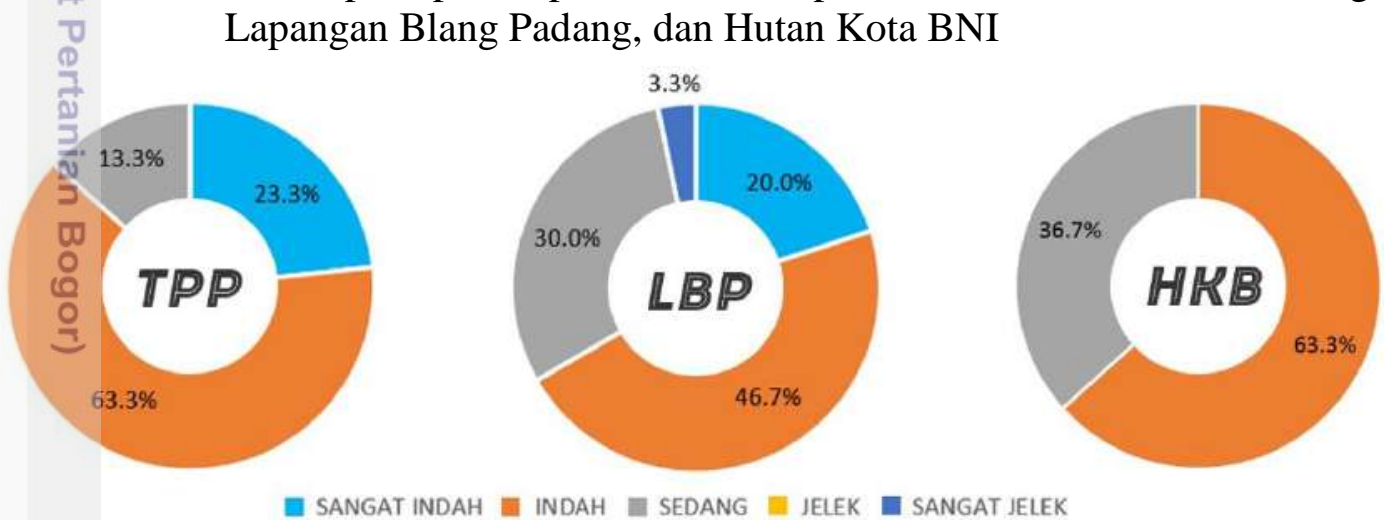

Gambar 39 Grafik persepsi responden terhadap estetika di Taman Putroe Phang, Lapangan Blang Padang, dan Hutan Kota BNI

\section{Preferensi Responden}

Preferensi responden yang diamati dalam penelitian ini meliputi preferensi terhadap aktivitas dan fasilitas taman yang diinginkan, jenis tanaman yang paling disukai dan yang perlu ditambahkan, serta saran responden dalam upaya untuk memperindah taman kota. Hal ini kemudian akan menjadi pertimbangan mengenai fungsi taman kota yang diinginkan oleh masyarakat. Berdasarkan hasil kuesioner, responden menginginkan adanya beberapa fasilitas pendukung di taman kota yang dapat menunjang aktivitas pengunjung. Fasilitas tersebut meliputi sarana wireless fidelity (wifi), taman bermain anak, kantin, toilet, dan mushola. Untuk menambah kéindahan taman kota, responden menginginkan adanya tanaman berbunga, 
berwarna, dan pohon buah yang dapat memberi kesan menarik, serta menghindari kebosanan. Untuk menambah kesejukan dan kenyamanan taman di tiga lokasi penelitian, responden menginginkan penggunaan tanaman dengan tajuk yang lebar T yang diletakkan di dekat lokasi bangku taman, sehingga responden dapat ternaungi dari cahaya matahari. Grafik presentase mengenai preferensi responden terhadap aktivitas dan fasilitas disajikan pada Gambar berikut ini.
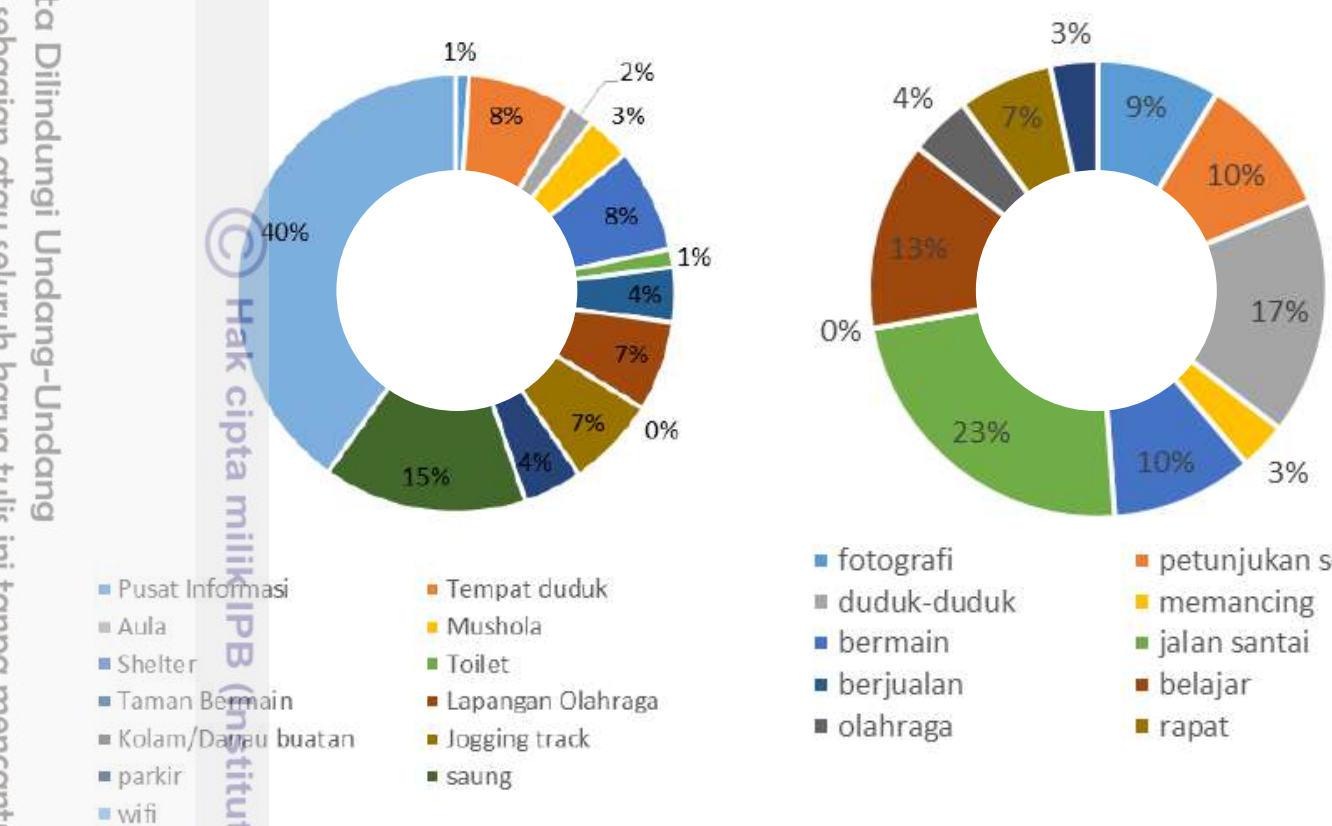

- fotografi

duduk-duduk

- bermain

- berjualan

- olahraga
- petunjukan seni

memancing

- jalan santai

- belajar

- rapat

Gambar $\overline{40}$ Grafik persentase preferensi responden mengenai aktivitas dan fasilitas di Taman Putroe Phang

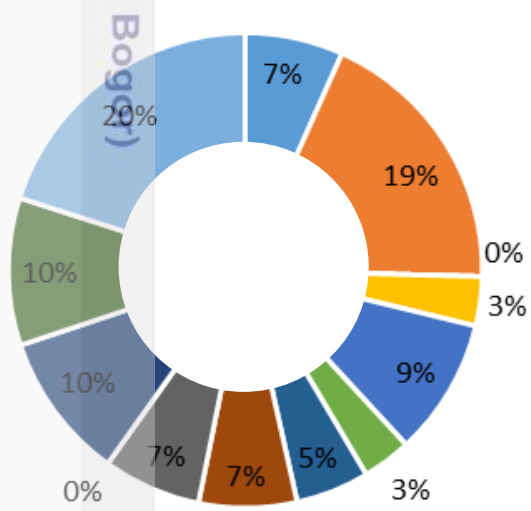

- Pusat Informasi

- Tempat duduk

- Mushola

- Toilet

- Shelter U.

- Taman Bermain

- Lapangan Olahraga

- Jogging track

- Saung

- Parkir

- Wifi

Panau buatan

Gambar 41 Grafik persentase preferensi responden mengenai aktivitas dan fasilitas

(O) di Lapangan Blang Padang

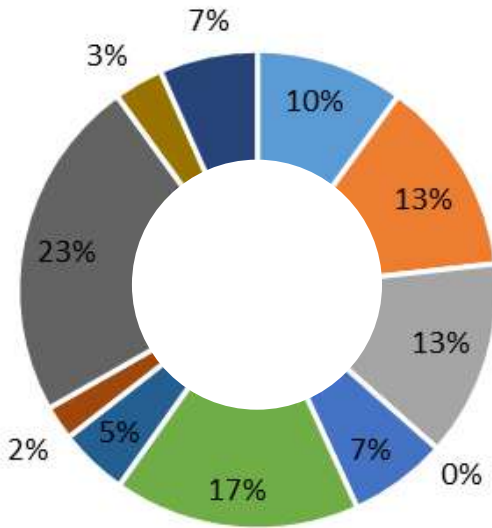

= fotografi

- duduk-duduk

- bermain

- berjualan

- olahraga

- pengajian
- petunjukan seni

II memancing

- jalan santai

- belajar

- rapat 

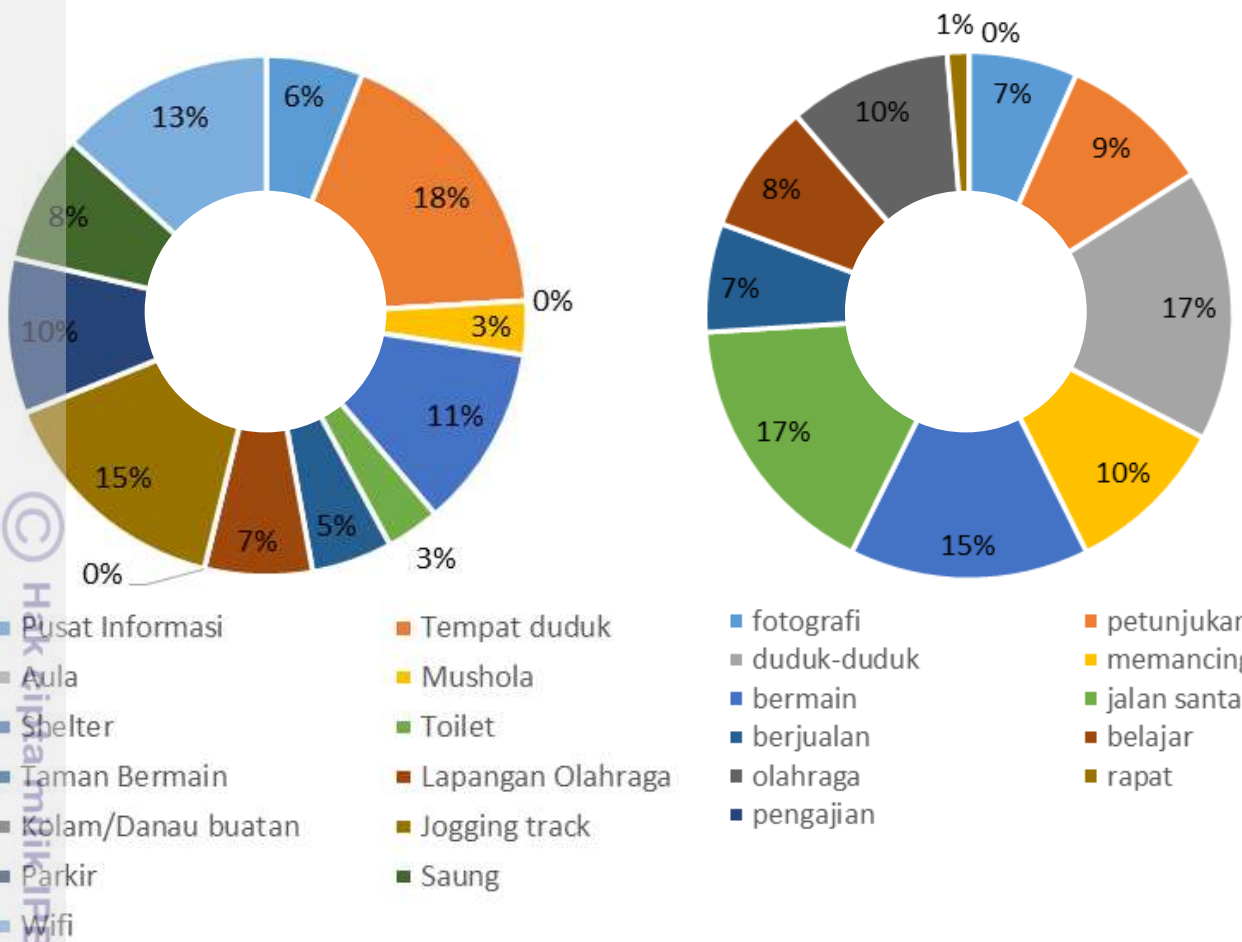
- fotografi
- duduk-duduk
bermain
- berjualan
- olahraga
- pengajian

- petunjukan seni

- memancing

Gambar 42 Grafik persentase preferensi responden mengenai aktivitas dan fasilitas di Hutan Kota BNI

\section{Rekomendasi}

\section{Aspek Kenyamanan Termal}

Kenyamanan udara dapat diciptakan oleh banyak faktor, di antaranya suhu udara, kelembapan, intensitas penyinaran matahari, dan angin. Berdasarkan hasil penelitian dari pengukuran suhu dan kelembapan udara, area pengukuran yang berada di bawah naungan pohon dan area pengukuran di atas tutupan rumput mempunyai nilai kenyamanan yang lebih tinggi dibandingkan area pengukuran di atas perkerasan dan area di luar taman. Hal tersebut menunjukkan bahwa elemen lanskap lunak berupa vegetasi efektif dalam meningkatkan kenyamanan termal suatu lanskap. Walau demikian, keefektifan vegetasi dalam meningkatkan kenyamanan termal dipengaruhi oleh faktor internal vegetasi tersebut. Secara umum, bentuk tajuk dan kerapatan tajuk yang menjadi faktor paling berpengaruh dalam peningkatan kenyamanan termal. Bentuk tajuk cenderung bulat, spreading, dan kolumnar lebih efektif dalam ameliorasi iklim mikro, begitu pula tajuk yang rapat lebih efektif dibandingkan tajuk yang renggang.

Secara spesifik, rekomendasi vegetasi pada tapak penelitian juga perlu memerhatikan vegetasi eksisting di setiap tapak. Peningkatan karakter taman melalui vegetasi khas pada masing-masing tapak menjadi nilai tambah tersendiri bagi taman tersebut. Oleh karena itu, rekomendasi vegetasi pada ketiga tapak terkait dengan upaya peningkatan kenyamanan termal tidak dapat digeneralisasi, tetapi masing-masing tapak memiliki rekomendasi vegetasi tersendiri. Rekomendasi vegetasi pada TPP meliputi tanaman tanjung (Mimusops elengi), Asam Jawa (Tamarindus indica), dan mahoni (Swietenia mahagoni). Lapangan Blang Padang meliputi tanaman trembesi (Samanea saman), angsana (Pterocarpus indicus), dan 
mahoni (Swietenia mahagoni). Sementara Hutan Kota BNI lebih penggunaan tanaman cemara laut (Casuarina equisetifolia), ketapang (Terminalia catappa), dan trembesi (Samanea saman).

T $\quad$ Penempatan vegetasi secara spasial sebaiknya diletakkan pada tempat-tempat yang sering didatangi oleh pengunjung, baik karena mempunyai objek lanskap yang menarik maupun pada area-area yang memiliki intensitas penggunaa tinggi. Walaupun demikian, jumlah kerapatan vegetasi di suatu tempat harus diperhatikan. Area yang memiliki vegetasi yang rapat menyebabkan kelembapan tinggi sehingga mengurangi kenyamanan tersebut. Oleh karena itu, pengaturan vegetasi perlu mempertimbangkan jarak tanam.

Berdasarkan hasil penelitian juga diketahui bahwa RTH dalam bentuk taman kota mempunyai andil dalam meningkatkan kenyamanan termal di Kota Banda Aceh. Oleh karena itu, dari sudut pandang lanskap makro, penambahan RTH di Kota Banda Aceh, baik dalam bentuk taman kota maupun bentuk lainnya diperlukan untuk meningkatkan kenyamanan termal kota.

\section{Aspek:Estetika}

\section{Taman Putroe Phang}

- Lanskap yang mempunyai nilai estetika tinggi didominasi oleh lanskap yang menggunakan kombinasi tiga elemen lanskap (vegetasi, air, dan perkerasan), mempunyai penutupan rumput yang merata, mempunyai tampilan fisik tanaman yang baik, dan tingginya tingkat kebersihan. Usaha untuk mempertahankan tingginya nilai estetika yaitu dengan melakukan pemeliharaan secara intensif berupa penyiraman, pemupukan, pemangkasan, dan menjaga struktur percabangan pada pohon maupun semak agar tetap menpunyai bentuk yang proporsional.

- Lanskap dengan nilai estetika sedang, ditunjukkan oleh lanskap yang mempunyai tampilan fisik vegetasi pohon yang baik namun memiliki penutupan rumput yang kurang merata dan rendahnya tingkat kebersihan. Untuk itu perlu dilakukan penanaman rumput pada beberapa area yang mempunyai penutupan rumput kurang rapat dan pemeliharaan intensif seperti penyiraman, pemupukan, dan pembersihan lingkungan.

Lanskap dengan nilai estetika rendah, ditunjukkan dengan tidak meratanya tutupan rumput dan warna rumput, rendahnya tingkat kebersihan, elemen dominan berupa perkerasan, serta minimnya penggunaan tanaman hias. Untuk meningkatkan nilai estetika sebaiknya dilakukan pemeliharaan intensif seperti penyemaian, pemupukan, penyiraman, dan pembersihan lingkungan. Penambahan tanaman hias berupa tanaman penutup tanah dan semak pada area sisi perkerasan/ jalan sangat disarankan agar dapat meningkatkan keindahan dan berfungsi sebagai pengarah. 

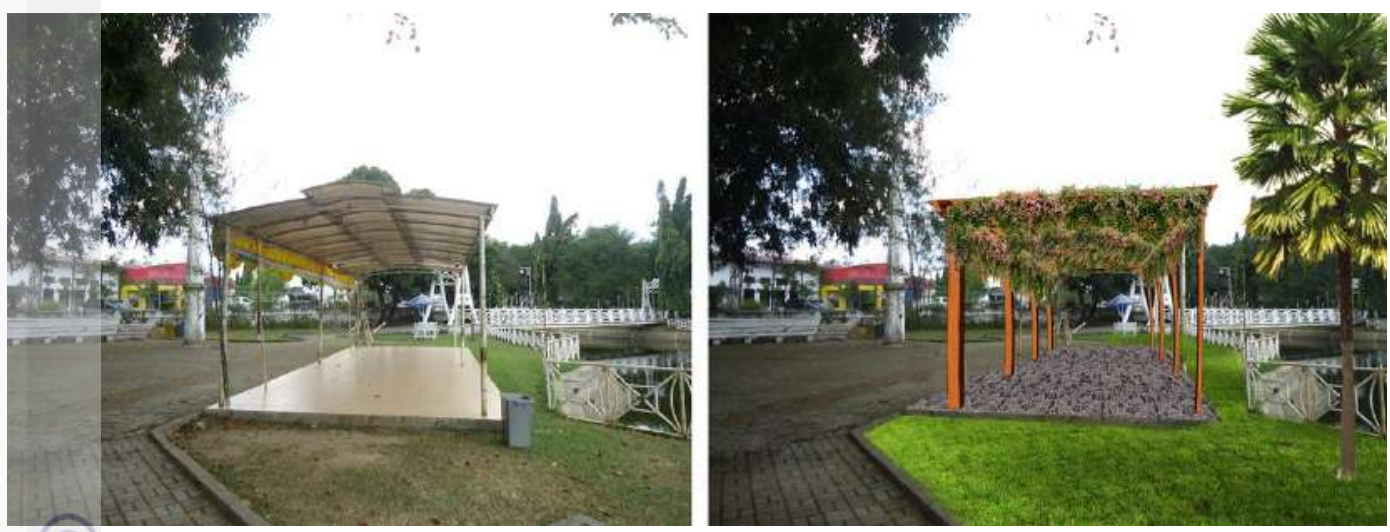

Gambar 43 Contoh penerapan rekomendasi pada Taman Putro Phang, (kiri) kondisi eksisting, (kanan) hasil rekomendasi

\section{Lapangan Blang Padang}

- Lanskap dengan nilai estetika tinggi ditunjukkan pada lanskap yang J. mempunyai tutupan rumput yang merata, tingkat kebersihan yang tinggi, dan Eterdapat penanaman pohon yang ditanam secara berulang pada jarak tertentu - yang berfungsi sebagai pengarah. Diusahakan mempertahankan kondisi yang ${ }^{w}$ sudah ada dengan pemeliharaan yang efektif sehingga visual tetap teratur dan 亏indah.

- Lanskap dengan nilai estetika sedang berada pada lanskap yang mempunyai Etutupan rumput yang merata, terdapat pohon pengarah, namun mempunyai Ttingkat kebersihan yang rendah. Usaha untuk meningkatkan nilai estetika Dapat dilakukan dengan cara pemeliharaan lanskap yang efektif dan penggunaan tanaman pohon yang mempunyai daun tidak mudah gugur.

- Lanskap yang tergolong ke dalam nilai estetika rendah ditunjukkan oleh lanskap yang mempunyai tutupan rumput dan warna perkerasan yang tidak merata, serta tingkat kebersihan rendah. Agar dapat meningkatkan nilai estetika perlu dilakukan perbaikan berupa pengecatan ulang pada beberapa perkerasan, penanaman rumput pada area rumput yang penutupannya tidak padat dan pemeliharaan efektif.
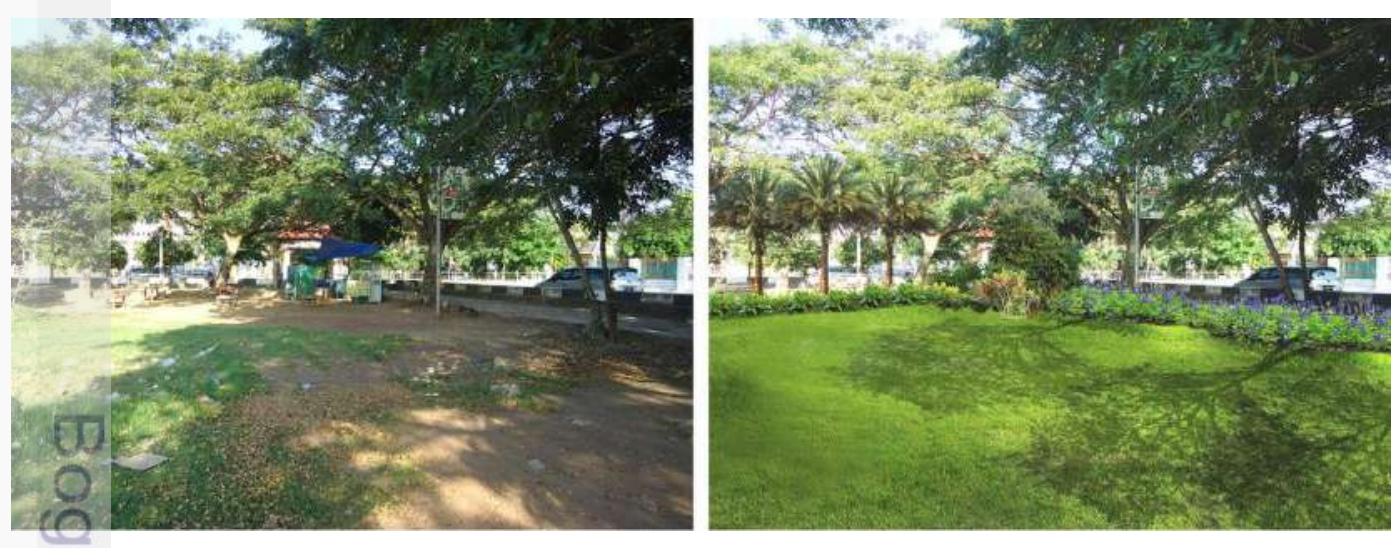

Gambar 44 Contoh penerapan rekomendasi pada Lapangan Blang Padang, (kiri) kondisi eksisting, (kanan) hasil rekomendasi 


\section{Hutan Kota BNI}

- Lanskap dengan nilai estetika tinggi ditunjukkan oleh lanskap yang menggunakan pohon pengarah pada sisi kanan dan kiri jalan atau deck yang dapat berfungsi sebagai pengarah dan menciptakan prinsip desain kesatuan (unity), terdapat jembatan yang dapat menjadi focal point, serta tingginya tingkat kebersihan. Untuk mempertahankan tingginya nilai estetika sebaiknya dilakukan pemeliharaan tanaman dan lingkungan yang efektif agar tampilan fisik tanaman dan lingkungan tetap baik.

Lanskap yang mempunyai nilai estetika sedang ditunjukkan oleh lanskap yang mempunyai pohon pengarah, namun mempunyai tingkat kebersihan yang rendah dan tutupan rumput, serta warna rumput yang tidak merata. Usaha agar dapat mempunyai nilai estetika tinggi dapat dilakukan dengan cara melakukan pemeliharaan yang intensif terhadap vegetasi rumput dan pengelolaan lingkungan.

Lanskap yang mempunyai nilai estetika rendah yaitu lanskap yang mempunyai penutupan rumput yang tidak merata, tingkat kebersihan rendah, dan tidak adanya focal point dan tanaman hias yang menjadikan lanskap terlihat kosong. Untukmeningkatkan nilai estetika dapat dilakukan dengan melakkukan pemeliharaan yang efektif serta penambahan tanaman hias berupa semak dan tanaman penutup tanah yang mempunyai warna kontras dengan lingkungannya agar dapat menjadi focal point atau tanaman pengarah.
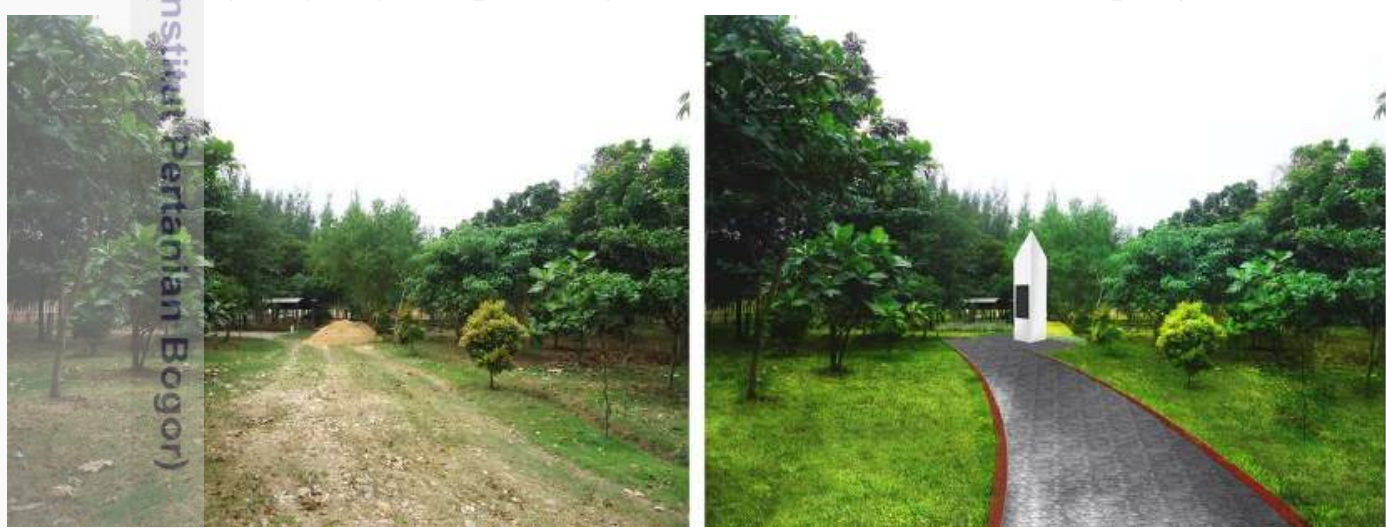

Gambar 45 Contoh penerapan rekomendasi pada Hutan Kota BNI, (kiri) kondisi eksisting, (kanan) hasil rekomendasi

\section{SIMPULAN DAN SARAN}

\section{Simpulan}

Berdasarkan hasil penelitian didapatkan bahwa suhu udara dan kelembaan udara pada waktu pengukuran dan area ukur menghasilkan nilai yang beragam. Nilai rata-rata suhu udara pada siang hari lebih tinggi dibandingkan nilai rata-rata suhu udara pada pagi dan sore hari. Sementara itu, nilai rata-rata kelembapan udara pada pagi dan sore hari memiliki nilai yang lebih tinggi dibandingkan siang hari. Area pengukuran di bawah naungan pohon memiliki nilai suhu udara rata-rata yang paling rendah dan menghasilkan kategori THI yang paling nyaman dibandingkan area ukur lainnya (perkerasan, di atas tutupan rumput, luar taman). 
Hasil dari analisis statistik menunjukkan bahwa adanya perbedaan pada lokasi penelitian Hutan Kota BNI dengan Taman Putroe Phang dan Lapangan Blang Padang mengenai interaksi antara waktu pengukuran dan area ukur terhadap suhu udara. Interaksi antara waktu pengukuran dan area pengukuran terhadap suhu udara terjadi pada lokasi penelitian Hutan Kota BNI. Sementara itu, pada lokasi penelitian Taman Putroe Phang dan Lapangan Blang Padang tidak tidak terjadi interaksi antara waktu pengukuran dan area ukur. Sistem tata hijau dengan vegetasi yang dominan serta pohon yang memberi naungan lebih luas mampu menjadikan kondisi udara dan kenyamanan akan lebih baik.

Berdasarkan hasil evaluasi kualitas estetika diperoleh faktor yang mempengaruhi kualitas estetika pada ketiga lokasi penelitian, yaitu kerapihan, penggunaan kombinasi elemen lanskap yang terdiri atas vegetasi, air, dan perkerasan, serta penataan lanskap yang melibatkan prinsip desain seperti irama dan pengulangan, keseimbangan, kesatuan, dan keharmonisan. Presentase nilai kualitas estetika pada ketiga lokasi penelitian, yaitu pada Taman Kota Putroe Phang terdapat $40 \%$ nilai SBE tinggi, $13 \%$ nilai SBE sedang, dan $47 \%$ nilai SBE rendah; Lapangan Blang Padang mempunyai SBE tinggi sebesar 37\%, nilai SBE sedang $53 \%$, dan nilai SBE rendah 10\%; Hutan Kota BNI memiliki nilai SBE tinggi sebesar $40 \%$, nilai SBE sedang $47 \%$ dan nilai SBE rendah $13 \%$. Penggunaan vegetasi hamparan dengan bunga dan warna yang berbeda-beda menjadi penambah nilai estetika. Melalui penyebaran kuesioner diketahui bahwa responden menginginkan adanya penambahan fasilitas di taman-taaman kota untuk menunjang aktivitas. Selaìn itu responden menginginkan penggunaan tanaman berbunga, pohon peneduh, dan pohon buah yang lebih banyak pada taman-taman untuk menambah keindahan dankenyamanan RTH taman kota.

\section{Saran}

Hasil dari penelitian ini diharapkan dapat menjadi masukan bagi Dinas Kebersihan dan Keindahan (DK3) Kota Banda Aceh agar dapat menciptakan RTH (taman kota) yang nyaman dan dapat meningkatkan keindahan kota. Untuk keepentingan perkembangan ilmu pengetahuan, sebaiknya perlu dilakukan penelitian mengenai pengaruh bentuk tajuk pohon terhadap tingkat kenyamanan termal, sehingga dapat diketahui bentuk tajuk pohon yang dapat meningkatkan tingkat kenyamanan termal.

\section{DAFTAR PUSTAKA}

Aprihatmoko F. 2013. Analisis Hubungan Antara Ruang Terbuka Hijau (RTH) dan Indeks Kenyamanan [skripsi]. Bogor (ID): Institut Pertanian Bogor.

Asiani Y. 2007. Pengaruh kondisi Ruang Terbuka Hijau (RTH) pada Iklim Mikro di Kota Bogor [tesis]. Depok (ID): Universitas Indonesia.

Booth NK. 1983. Basic Element of Landscape Architecture Design. Illnois (US): Waveland Press inc.

Brooks GR. 1988. Site Planning: Environment, Process, and Development. New (York (US): Prentice Hall Inc. 
Daniel TC, Boster RS. 1976. Measuring Landscape Aesthetics: the Scenic Beauty Estimation Method. USDA Forest Service Research paper. RM-167

[DK3] Dinas Kebersihan dan Keindahan. 2014. Profil Taman Kota Banda Aceh 2014. Banda Aceh (ID):DK3

DK3 Banda Aceh. 2014. Dinas Kebersihan dan Keindahan [Internet]. [diunduh 2014 oktober 12]. Tersedia pada: http://www.kebersihan.bandaacehkota.go.id/

Eckbo G. 1964. Urban Landscape Design. New York (US): McGraw-Hill Book Co, Inc.

Effendy S, Bey A, Zain AFM, Santosa I. 2006. Peranan Ruang Terbuka Hijau dalam Mengendalikan Suhu Udara dan Urban Heat Island Wilayah JABOTABEK. $J$ Agromet Indonesia 20(1):23-33

Emmanuel R. 2005 Thermal Comfort Implications of Urbanization in a Warmhumid City: The Colombo Metropolitan Region (CMR), Sri Lanka. J Building and Evironment 40: 1591-1601.

Fandeli C, Muhammad. 2009. Prinsip-Prinsip Dasar Mengkonservasi Lanskap. Yogyakarta (ID): Gadjah Mada University Press.

Gomez F, Gil L, Jabaloyes J. 2004. Experimental Investigation on the Thermal Comfort in the City: Relationship with the Green Areas, Interaction with the Urban Microclimate. J Building and Environment 39: 1077-1086.

Hadi R, Lila KA, Gunadi IGA. 2012. Evaluasi Indeks Kenyamanan Taman Kota (Lapangan Puputan Badung I Gusti Ngurah Made Agung) Denpasar, Bali. J Agroekoteknologi Tropika 1:34- 45.

Hakim R 2012. Komponen Perancangan Arsitektur Lanskap. Jakarta (ID): Bumi Aksarâ.

Handoko.1993. Klimatologi Dasar. Jakarta (ID): PT Dunia Pustaka Jaya. 1995.Klimatologi Dasar Landasan Pemahaman Fisika Atmosfer dan Unsur-unsur Iklim. Jakarta (ID): Pustaka Jaya.

Hidayat IW. 2010. The Ecological Role of Trees and Their Interactions in Forming the Microclimate Amenity of Environment. J Bumi Lestari 10(2):182- 190.

Joga N, Ismaun I. 2011. RTH 30\%! Resolusi (Kota) Hijau. Jakarta (ID): Gramedia Pustaka Utama.

Kamal A, Salmawaty. 2013. Banda Aceh Heritage Jalur Jejak Budaya dan Tsunami. Banda Aceh (ID): Pustaka Bustanussalatin.

Lakitan B. 2002. Dasar-dasar Klimatologi. Jakarta (ID): Raja Grafindo Persada.

Laurie M. 1986. Pengantar Kepada Arsitektur Pertamanan (terjemahan). Bandung (ID): Intermata. 130 hal.

Maharani E. 2015. Suhu Banda Aceh Terpanas di Indonesia [Internet]. [diunduh 2015 des 1]. Tersedia pada: http://republika.co.id/

Mahardi F. 2013. Evaluasi Fungsi Ekologis dan Estetika Pada Beberapa Taman Kota di Jakarta [skripsi]. Bogor (ID): Institut Pertanian Bogor.

[Pemkot] Pemerintah Kota Banda Aceh. 2009. Qanun No.4 Tahun 2009 Tentang Rencana Tata Ruang Wilayah Kota Banda Aceh 2009-2029. Banda Aceh (ID): Pemkot Banda Aceh.

Purnomo AB. 2003. Pengaruh Bayangan Bangunan dan Vegetasi pada Suhu Udaradi Kampus A, Universitas Trisakti.

Rushayati SB, Alikodra HS, Dahlan EN, Purnomo H. 2011. Pengembangan Ruang Terbuka Hijau berdasarkan Distribusi Suhu Permukaan di Kabupaten Bandung. Forum Geografi [Internet]. [diunduh 29 Desember 2015]; 25 (1):17-26. Tersedia 
pada:http://digilib.itb.ac.id/files/disk1/620/jbptitbpp-gdl-erliannurn-30974-72008ta-5.pdf

Ruswan M. 2006. Analisis Pengaruh Elemen Lanskap Terhadap Kualitas Estetika Kota Depok [skripsi]. Bogor (ID): Institut Pertanian Bogor.

Shahidan MF, Shariff MKM, Jones P, Shalleh E, Abdullah AM. 2010. A Comparison of Mesua ferrea L. And Hurra crepitans L. For Shade Creation and Radiation Modification in Improving Thermal Comfort. J Landscape and Urban Planning 97:168181.

Simonds JO. 1983. Landscape Architecture. New York (US): McGraw-Hill Book Co, Inc. $331 \mathrm{p}$.

Soeriaatmadja A. 2008. Khasanah Tanaman Bunga dan Buah Taman Raja-raja Bustanussalatin Aceh. Banda Aceh (ID): Rantf.

Tursilowati L. 2007. Use of Remote Sensing and GIS to Compute Temperature Humidity Index as Human Comfort Indicator Relate with Land Use-Land Cover Change (LULC) in Surabaya. The 73rd International Symposium on Sustainable Humanosphere:160-166.

Tjasyono HKB. 1996. Klimatologi Terapan. Bandung (ID): Pionir Jaya. .2008. Meteorologi Terapan. Bandung (ID): Penerbit ITB.

Untermann R, Small R. 1986. Perencanaan Tapak dan Perumahan (terjemahan.). Bandung (ID): Intermatra. 241 hal.

Viltegas JC, David DB, Chris BZ, Patrick DR. 2010. Seasonally Pulsed Heterogeneity in Microclimate: Phenology and Cover Effects along Deciduous Grassland-Forest Continuum. Vadose Zone Journal 9 (3): 537-547.

Vitâsari D. 2004. Evaluasi Tata Hijau Jalan pada Tiga Jalan Kawasan Pemukiman Besar di Kab. Bogor, Jawa Barat [Skripsi]. Bogor (ID): Institut Pertanian Bogor. Wirasasmita M et al. 2003. Aplikasi Iklim Terhadap Perkembangan Urban, Metropolitan Bandung. Bandung (ID): Pusat Pemanfaatan Sains Atmosfer dan Iklim- LAPAN. 


\section{LAMPIRAN}

T Lampiran 1 Kuesioner Penelitian

FAKULTAS PERTANIAN

INSTITUT PERTANIAN BOGOR

KUISIONER PENELITIAN

EVALUASI TINGKAT KENYAMANAN TERMAL DAN ESTETIKA RUANG TERBUKA HIJAU KOTA BANDA ACEH

Lokasi

Tanggal Pengambilan :

No. Kuisioner

Assalamualaikum Wr. Wb.

Saya Azwinur, mahasiswa semester 8 Departemen Arsitektur Lanskap di Institut Pertanian Bogor. Saya mengharapkan

bantuan dari Bapak/lbu/Kakak/Adik untuk mengisi kuisioner penelitian saya yang berjudul Evaluasi Tingkat Kenyamanan

Termal dan Estetika Ruang Terbuka Hijau Kota Banda Aceh. Terima kasih atas kesediaannya. (Identitas responden akan

dijaga kerahasjanya, hanya digunakan untuk penelitian ini saja).

A. Karakteristik Responden

1). Nama

2). Umur

3). Jenis kelamin

4). Alamat $\overline{\bar{\eta}}$

5). Pendidikan terakhir Anda:
(a) SD
(b) SMP
(c) SMA
(d) Perguruan tinggi
(e) Lainnya

6). Pekerjaan/ Profesi Anda saat ini:

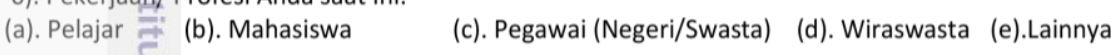

B. Preferensi Responden

7). Tujuan Anda mengunjungi taman / RTH:
(a). Rekreasi-
(b). Belajar
(c). Olahraga
(d). Ingin tahu
(e). Lainnya

8). Kunjungañ Anda ke taman / RTH untuk yang :
(a). Pertamakali
(b). Kedua kali
(c). Ketiga kali

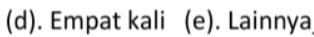

9). Frekuensikunjungan Anda:
(a).Setiap hari
(b). Setiap minggu
(c). Setiap bulan
(d). Tidak tentu
(e). Lainnya

10. Jarak taman / RTH dari tempat tinggal Anda:
(a). $<500 \mathrm{~m}$
(b). $500 \mathrm{~m}-3 \mathrm{~km}$
(c). $3 \mathrm{~km}-5 \mathrm{~km}$
(d). $5 \mathrm{~km}-10 \mathrm{~km}$
(e). $>10 \mathrm{~km}$

11. Waktu Anda biasa mengunjungi taman / RTH:
(a). Pagi
(b). Siang
(c). Sore
(d). malam

12. Hari apa biasanya anda mengunjungi taman / RTH ini :
(a). Hari kerja
(b). Akhir Pekan
(c). Hari Libur
(d). Lainnya

13. Bersama siapa anda biasanya ke taman / RTH :
(a). Sendiri
(b). Teman
(c). Keluarga
(d). Lainnya

14. Berapa lama anda biasanya berada di dalam taman / RTH tersebut :
(a). $<30$ menit
(b). 30 - $60 \mathrm{mnt}$
(c). 1 jam-3 jam
(d). $3 \mathrm{jam}-5 \mathrm{jam}$
(e). $>5$ jam

C. Persepsi Responden

15. Kesan Anda tentang pemandangan (estetika) taman ini:
(a).Sangat indah
(b). Indah
(c). Sedang
(d). Jelek
(e). Sangat jelek 


\section{Lampiran 1 Kuesioner Penelitian (lanjutan)}

16. Kesan Anda tentang penataan taman / RTH
(a). sangat baik
(b). baik
(c). Sedang
(d). Jelek
(e). Sangat jelek

17. Kesan Anda terhadap kenyamanan suhu di taman / RTH:
(a). Sangat sejuk
(b). Sejuk
(c). Sedang
(d). Panas
(e). Sangat panas

18. Kesan Anda tentang kelembaban udara taman:
(a).Sangat kering
(b). Kering
(c). Sedang
(d). Lembab
(e). Sangat lembab

19. Kesan Anda terhadap kebersihan taman:
(a). Sangat bersih
(b). Bersih
(c). Sedang
(d). Kotor
(e). Sangat kotor

20. Sebutkan lokasi mana saja menurut anda paling bersih ? (jika ada)

I

21. Sebutkan lokasi mana saja menurut anda paling kotor? (jika ada)

$\overline{0}$

22. Sebutkan tanaman apa yang anda sukai yang terdapat pada taman tersebut ??

ㅍ.

23. Tanaman apa saja menurut anda perlu di tambahkan pada taman / RTH ini ?

co

$=$

24. Aktivitas/kegiatan apa saja yang ingin Anda lakukan, jika kawasan taman ini akan dikembangkan lebih lanjut. Urutkan menggunakan angka menurut anda paling penting ? ${ }^{* *}$ )

\begin{tabular}{|l|l|}
\hline No & \multicolumn{2}{|c|}{ Aktifitas } \\
\hline 1 & Fotografi \\
\hline 2 & Pertunjukan seni \\
\hline 3 & Duduk-duduk \\
\hline 4 & Memancing \\
\hline 5 & Bermain \\
\hline 6 & Jalan santai \\
\hline 7 & Berjualan \\
\hline 8 & Belajar \\
\hline 9 & Olahraga \\
\hline 10 & Rapat \\
\hline 11 & Pengajian \\
\hline 12 & Lainnya (sebutkan).... \\
\hline
\end{tabular}

2.

5 .

6

8.

9

10.

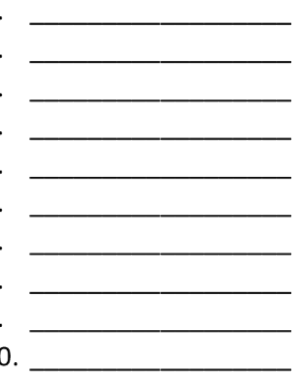

25. Jenis fasilitas apa saja yang anda inginkan untuk menunjang kegiatan tersebut?**)

\begin{tabular}{|l|l|}
\hline No & \multicolumn{1}{|c|}{ Fasilitas } \\
\hline 1 & Pusat informasi \\
\hline 2 & Tempat duduk \\
\hline 3 & Aula \\
\hline 4 & Mushala \\
\hline 5 & Shelter \\
\hline 6 & Toilet \\
\hline 7 & Taman bermain \\
\hline 8 & Lapangan olahraga \\
\hline 9 & Kolam/danau buatan \\
\hline
\end{tabular}

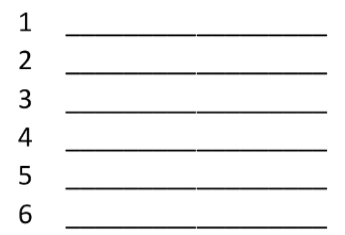



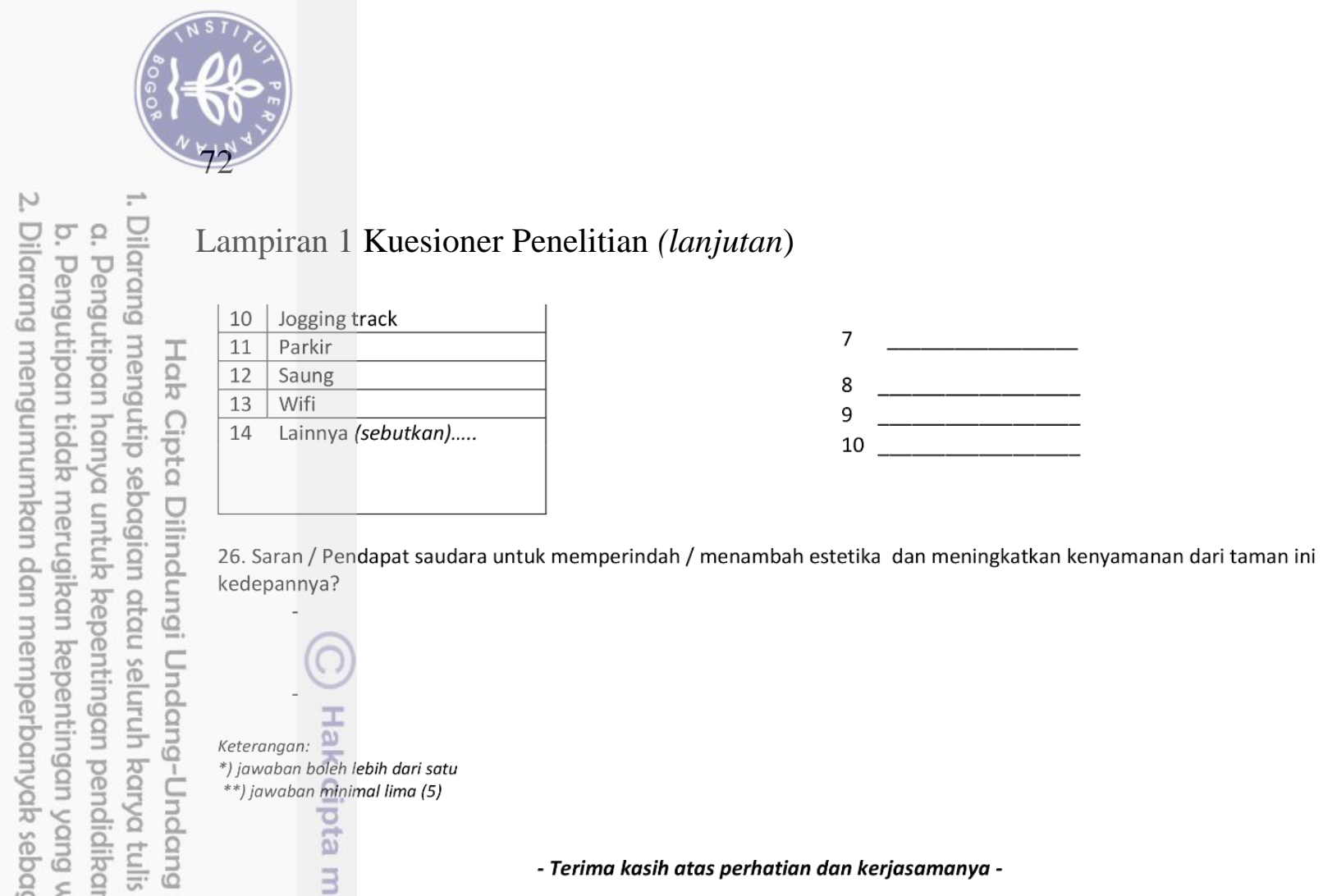
Lampiran 2 Kuesioner penilaian estetika

\section{KUISIONER}

Evaluasi Kualitas Estetika Ruang Terbuka Hijau Kota Banda Aceh (Taman Putro Phang, Hutan Kota BNI, dan Lapangan Blang Padang)

\section{Data Responden}

Jenis Kelamin :

Usia

Dept / Smstr :

No. HP

Skala Penilaian Responden

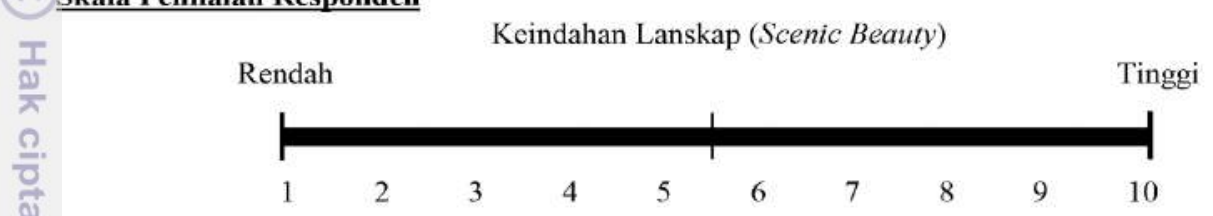

Penilaian Lanskap

\begin{tabular}{|c|c|c|c|c|c|}
\hline \multicolumn{2}{|c|}{ (Putroe Phang) } & \multicolumn{2}{|c|}{ (Blang Padang } & \multicolumn{2}{|c|}{ ( H. Kota BNI) } \\
\hline $\mathrm{A}=\ldots$ & $\mathrm{P}=\ldots$ & $\mathrm{A}=\ldots$ & $\mathrm{P}=\ldots$ & $A=\ldots$ & $\mathrm{P}=\ldots$. \\
\hline $\mathrm{B}=\ldots$. & $\mathrm{Q}=\ldots$. & $\mathrm{B}=\ldots$ & $\mathrm{Q}=\ldots$. & $\mathrm{B}=\ldots$ & $\mathrm{Q}=\ldots$. \\
\hline $\mathrm{C}=\ldots$. & $\mathrm{R}=\ldots$. & $\mathrm{C}=\ldots$ & $\mathrm{R}=\ldots$. & $\mathrm{C}=\ldots$. & $\mathrm{R}=\ldots$. \\
\hline $\mathrm{D}=\ldots$ & $\mathrm{S}=\ldots$ & $\mathrm{D}=\ldots$ & $\mathrm{S}=\ldots$. & $\mathrm{D}=\ldots$ & $\mathrm{S}=\ldots$. \\
\hline $\mathrm{E}=\ldots$. & $\mathrm{T}=\ldots$. & $\mathrm{E}=\ldots$. & $\mathrm{T}=\ldots$. & $E=\ldots$ & $\mathrm{T}=\ldots$. \\
\hline $\mathrm{F}=\ldots$ & $\mathrm{U}=\ldots$. & $\mathrm{F}=\ldots$ & $\mathrm{U}=\ldots$. & $\mathrm{F}=\ldots$ & $\mathrm{U}=\ldots$. \\
\hline $\mathrm{G}=\ldots$. & $\mathrm{V}=\ldots$ & $\mathrm{G}=\ldots$ & $\mathrm{V}=\ldots$ & $\mathrm{G}=\ldots$. & $\mathrm{V}=\ldots$ \\
\hline $\mathrm{H}=\ldots$ & $\mathrm{W}=\ldots$ & $\mathrm{H}=\ldots$ & $\mathrm{W}=\ldots$ & $\mathrm{H}=\ldots$. & $\mathrm{W}=\ldots$ \\
\hline$I=\ldots$. & $X=\ldots$ & $\mathrm{I}=\ldots$. & $X=\ldots$ & $\mathrm{I}=\ldots$. & $\mathrm{X}=\ldots$. \\
\hline $\mathbf{J}=\ldots$ & $\mathrm{Y}=\ldots$. & $\mathrm{J}=\ldots$. & $\mathrm{Y}=\ldots$. & $\mathrm{J}=\ldots$. & $\mathrm{Y}=\ldots$. \\
\hline $\mathrm{K}=\ldots$ & $Z=\ldots$ & $\mathrm{K}=\ldots$ & $\mathrm{Z}=\ldots$ & $\mathrm{K}=\ldots$ & $\mathrm{Z}=\ldots$. \\
\hline $\mathrm{L}=\ldots$ & $\mathrm{AA}=\ldots$ & $\mathrm{L}=\ldots$ & $\mathrm{AA}=\ldots$ & $\mathrm{L}=\ldots$ & $\mathrm{AA}=\ldots$ \\
\hline $\mathrm{M}=\ldots$. & $\mathrm{AB}=\ldots$. & $\mathrm{M}=\ldots$ & $\mathrm{AB}=\ldots$ & $\mathrm{M}=\ldots$. & $\mathrm{AB}=\ldots$ \\
\hline $\mathrm{N}=\ldots$ & $\mathrm{AC}=\ldots$. & $N=\ldots$ & $\mathrm{AC}=\ldots$ & $N=\ldots$ & $\mathrm{AC}=\ldots$. \\
\hline $\mathrm{O}=\ldots$. & $\mathrm{AD}=\ldots$. & $\mathrm{O}=\ldots$ & $\mathrm{AD}=\ldots$. & $\mathrm{O}=\ldots$ & $\mathrm{AD}=\ldots$ \\
\hline
\end{tabular}

Komentar : 
Lampiran 3 Hasil Anova dan uji beda Suhu Taman Putroe Phang

\begin{tabular}{|l|r|r|r|r|r|}
\hline Source & $\begin{array}{c}\text { Type III Sum } \\
\text { of Squares }\end{array}$ & \multicolumn{1}{c|}{ df } & Mean Square & \multicolumn{1}{c|}{ F } & Sig. \\
\hline Corrected & 158,139 a & 11 & 14.376 & 31.487 & .000 \\
Model & 27918.233 & 1 & 27918.233 & 61145.858 & .000 \\
Intercept & 23.825 & 3 & 7.942 & 17.393 & .000 \\
TitikUkur & 130.618 & 2 & 65.309 & 143.038 & .000 \\
Waktu & 3.696 & 6 & .616 & 1.349 & .275 \\
TitikUkur * & 10.958 & 24 & .457 & & \\
Waktu & 28087.329 & 36 & & & \\
Error & 169.097 & 35 & & & \\
Total (O) & & & & \\
Corrected Total & & & &
\end{tabular}

\begin{tabular}{|c|c|c|c|c|}
\hline \multicolumn{5}{|l|}{ Titik Ukur } \\
\hline 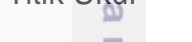 & \multirow[b]{2}{*}{$\mathrm{N}$} & \multicolumn{3}{|c|}{ Subset } \\
\hline ב. & & 1 & 2 & 3 \\
\hline $\bar{\lambda} \mathrm{NP}$ & 9 & 26.763889 & & \\
\hline $\bar{\nabla} T R$ & 9 & & 27.533333 & \\
\hline$=P$ & 9 & & 28.102778 & \\
\hline$\vec{\omega} \mathrm{L}$ & 9 & & & 28.991667 \\
\hline Sig. & & 1.000 & .086 & 1.000 \\
\hline
\end{tabular}

Duncana,b

\begin{tabular}{|l|r|r|r|r|}
\hline Waktu & & \multicolumn{3}{|c|}{ Subset } \\
\cline { 3 - 5 } & $\mathrm{N}$ & \multicolumn{1}{|c|}{1} & \multicolumn{1}{|c|}{3} \\
\hline Pagi $\frac{1}{3}$ & 12 & 25.806250 & & \\
Sore 을 & 12 & & 27.346875 & \\
Siang & & & \\
Sig. & 12 & & & 30.390625 \\
\hline
\end{tabular}

Lampiran 4 Hasil Anova dan uji beda Suhu Lapangan Blang Padang

\begin{tabular}{|l|r|r|r|r|r|}
\hline Source & \multicolumn{1}{c|}{$\begin{array}{c}\text { Type III Sum } \\
\text { of Squares }\end{array}$} & \multicolumn{1}{c|}{ df } & Mean Square & \multicolumn{1}{c|}{ F } & \multicolumn{1}{c|}{ Sig. } \\
\hline Corrected Model & $200,880^{\mathrm{a}}$ & 11 & 18.262 & 59.147 & .000 \\
Intercept & 28280.028 & 1 & 28280.028 & 91593.944 & .000 \\
TitikUkur & 27.172 & 3 & 9.057 & 29.335 & .000 \\
Waktu & 170.613 & 2 & 85.306 & 276.292 & .000 \\
TitikUkur*Waktu & 3.096 & 6 & .516 & 1.671 & .171 \\
Error @ & 7.410 & 24 & .309 & & \\
Total & 28488.318 & 36 & & & \\
Corrected Total & 208.290 & 35 & & & \\
\hline
\end{tabular}


Duncan $^{\mathrm{a}}, \mathrm{b}$

\begin{tabular}{|r|r|r|r|r|}
\hline \multicolumn{2}{|l|}{ Titik Ukur } & \multicolumn{3}{|c|}{ Subset } \\
\cline { 3 - 5 } & $\mathrm{N}$ & 1 & 2 & 3 \\
\hline NP & 9 & 26.788889 & & \\
TR & 9 & & 27.877778 & \\
P & 9 & & 28.223611 & 29.220833 \\
L & 9 & & & 1.000 \\
\hline
\end{tabular}

Duncan ${ }^{\mathrm{a}}, \mathrm{b}$

\begin{tabular}{|l|r|r|r|r|}
\hline Waktu & & \multicolumn{3}{|c|}{ Subset } \\
\cline { 3 - 5 } & $\mathrm{N}$ & 1 & \multicolumn{1}{|c|}{2} & \multicolumn{1}{|c|}{3} \\
\hline Pagi & 12 & 25.738542 & & \\
Sore & 12 & & 27.389583 & \\
Siang & 12 & & & 30.955208 \\
Sig.: & & 1.000 & 1.000 & 1.000 \\
\hline
\end{tabular}

$\overline{\bar{\nabla}}$

Lampiran 5 Hasil Anova dan uji beda Suhu Hutan Kota BNI

Dependent Variable:Suhu HKB

\begin{tabular}{|l|r|r|r|r|r|}
\hline Source & $\begin{array}{c}\text { Type III Sum } \\
\text { of Squares }\end{array}$ & \multicolumn{1}{c|}{ df } & Mean Square & \multicolumn{1}{c|}{ F } & Sig. \\
\hline Corrected Model & $165,737^{\mathrm{a}}$ & 11 & 15.067 & 109.106 & .000 \\
$\underset{J}{\text { Intercept }}$ & 27947.481 & 1 & 27947.481 & 202379.217 & .000 \\
TitikUkur & 24.303 & 3 & 8.101 & 58.662 & .000 \\
Waktu & 138.650 & 2 & 69.325 & 502.012 & .000 \\
TitikUkur * Waktu & 2.783 & 6 & .464 & 3.359 & .015 \\
Error & 3.314 & 24 & .138 & & \\
Total & 28116.532 & 36 & & & \\
Corrected Total & 169.051 & 35 & & & \\
\hline
\end{tabular}

Perhatikan, semuanya significant tabel diatas

\begin{tabular}{|c|c|c|c|c|c|c|}
\hline \multicolumn{2}{|c|}{ Titik Ukur } & \multirow[b]{2}{*}{$\mathrm{N}$} & \multicolumn{4}{|c|}{ Subset } \\
\hline & & & 1 & 2 & 3 & 4 \\
\hline & $\mathrm{NP}$ & 9 & 26.705556 & & & \\
\hline & TR & 9 & & 27.684722 & & \\
\hline $\mathrm{C}$ & $P$ & 9 & & & 28.061111 & \\
\hline & $L$ & 9 & & & & 28.998611 \\
\hline & Sig. & & 1.000 & 1.000 & 1.000 & 1.000 \\
\hline
\end{tabular}




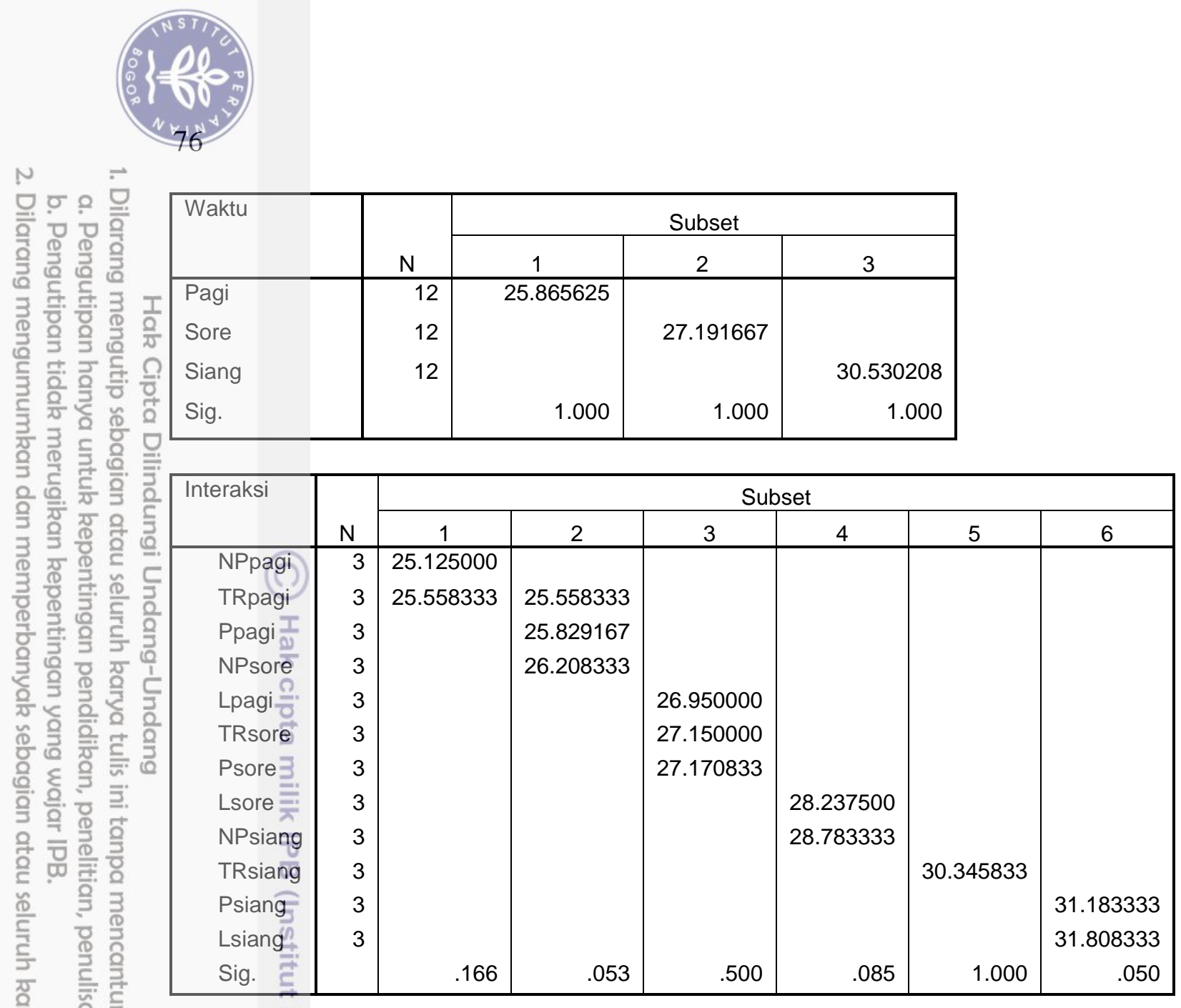

Lampiran6 Hasil Anova dan uji beda Suhu Ketiga lokasi

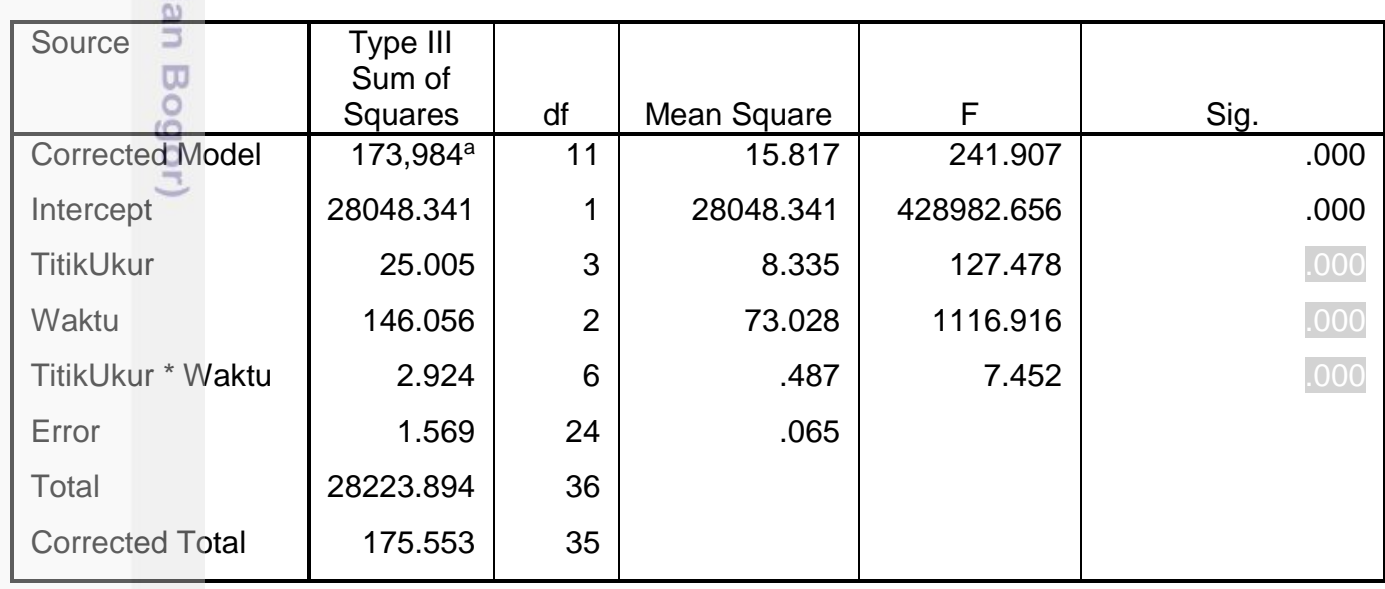

\begin{tabular}{|c|c|c|c|c|c|c|}
\hline \multirow{2}{*}{$\begin{array}{l}\text { Titik Ukur } \\
\\
00\end{array}$} & & \multirow[b]{2}{*}{$\mathrm{N}$} & \multicolumn{4}{|c|}{ Subset } \\
\hline & & & 1 & 2 & 3 & 4 \\
\hline 3 & $\mathrm{NP}$ & 9 & 26.752778 & & & \\
\hline 0 & $\mathrm{TR}$ & 9 & & 27.698611 & & \\
\hline 7 & $P$ & 9 & & & 28.129167 & \\
\hline$D$ & L & 9 & & & & 29.070370 \\
\hline$=$ & Sig. & & 1.000 & 1.000 & 1.000 & 1.000 \\
\hline
\end{tabular}


Duncan ${ }^{\mathrm{a}}, \mathrm{b}$

\begin{tabular}{|l|r|r|r|r|}
\hline Waktu & & \multicolumn{3}{|c|}{ Subset } \\
\cline { 3 - 5 } & $\mathrm{N}$ & 1 & \multicolumn{1}{c|}{2} & \multicolumn{1}{c|}{3} \\
\hline Pagi & 12 & 25.803472 & & \\
Sore & 12 & & 27.309375 & 30.625347 \\
Siang & 12 & & & 1.000 \\
Sig. & & 1.000 & 1.000 & \\
\hline
\end{tabular}

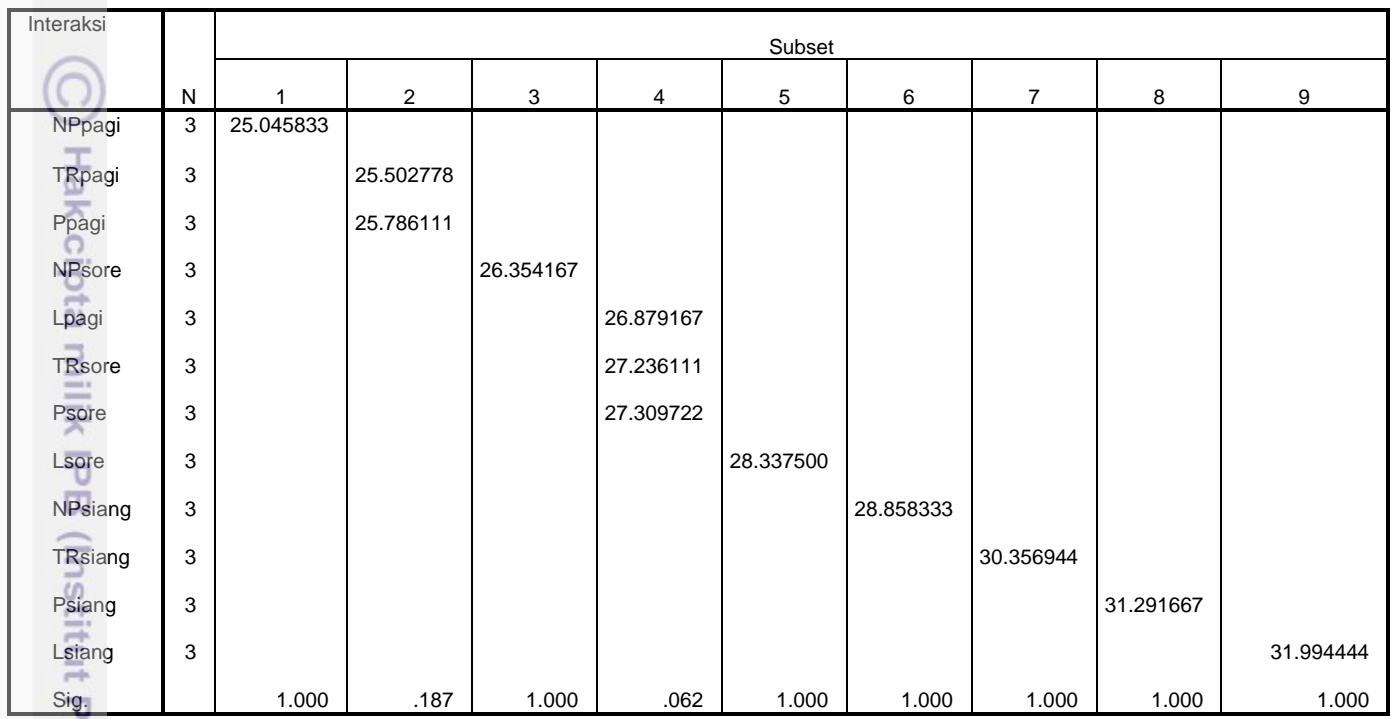

Lampiran 7 Hasil Anova dan uji beda kelembaban Taman Putroe Phang

\begin{tabular}{|c|c|c|c|c|c|}
\hline Source & $\begin{array}{l}\text { Type III Sum of } \\
\text { Squares }\end{array}$ & df & Mean Square & $\mathrm{F}$ & Sig. \\
\hline Corrected Model & $915,936^{a}$ & 11 & 83.267 & 13.967 & .000 \\
\hline Intercept & 200293.543 & 1 & 200293.543 & 33596.121 & .000 \\
\hline TitikUkur & 342.922 & 3 & 114.307 & 19.173 & .000 \\
\hline Waktu & 562.587 & 2 & 281.293 & 47.183 & .000 \\
\hline TitikUkur * Waktu & 10.427 & 6 & 1.738 & .291 & .935 \\
\hline Error & 143.083 & 24 & 5.962 & & \\
\hline Total & 201352.563 & 36 & & & \\
\hline Corrected Total & 1059.019 & 35 & & & \\
\hline
\end{tabular}

\begin{tabular}{|c|c|c|c|c|c|}
\hline \multicolumn{2}{|c|}{ Titik Ukur } & \multirow[b]{2}{*}{$\mathrm{N}$} & \multicolumn{3}{|c|}{ Subset } \\
\hline & & & 1 & 2 & 3 \\
\hline D & $\mathrm{L}$ & 9 & 71.52778 & & \\
\hline 0 & $\mathrm{P}$ & 9 & 72.36111 & & \\
\hline 0 & $\mathrm{TR}$ & 9 & & 75.02778 & \\
\hline 7 & NP & 9 & & & 79.44444 \\
\hline$\Delta$ & Sig. & & .476 & 1.000 & 1.000 \\
\hline
\end{tabular}



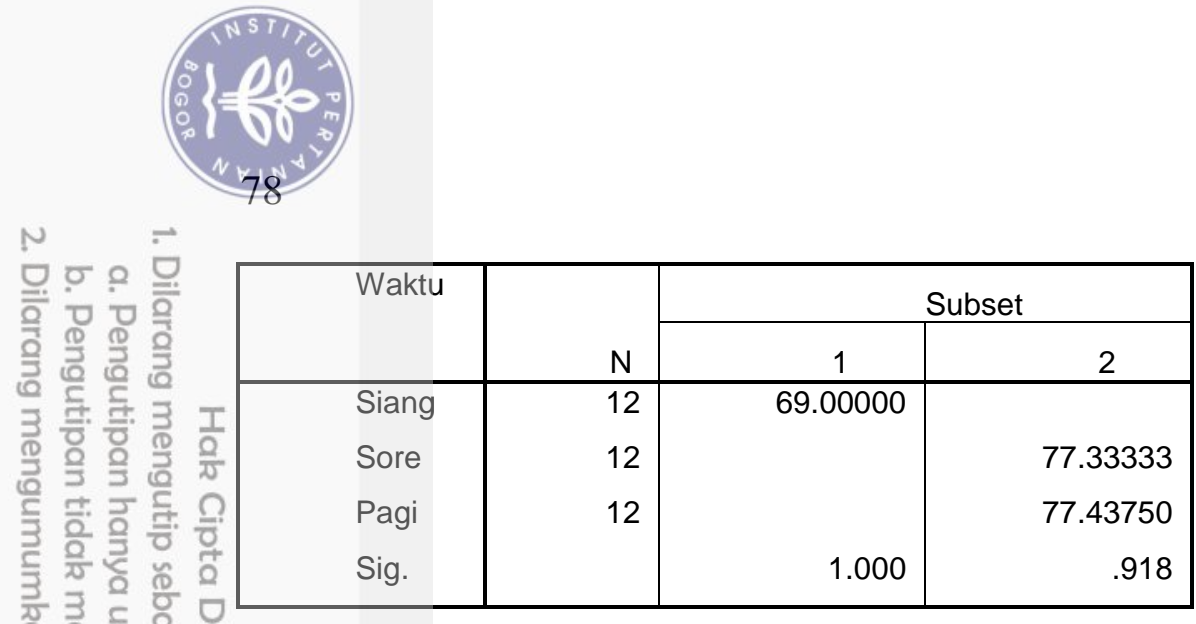

Lampiran 8 Hasil Anova dan uji beda kelembaban Lapangan Blang Padang

要

\begin{tabular}{|c|c|c|c|c|c|}
\hline $\begin{array}{ll}\text { Source } & \frac{I}{0} \\
& \end{array}$ & $\begin{array}{l}\text { Type III Sum } \\
\text { of Squares }\end{array}$ & $\mathrm{df}$ & Mean Square & $\mathrm{F}$ & Sig. \\
\hline Corrected Model & $1345,274^{a}$ & 11 & 122.298 & 17.218 & .000 \\
\hline Intercept & 199213.444 & 1 & 199213.444 & 28046.916 & .000 \\
\hline TitikUkur & 347.229 & 3 & 115.743 & 16.295 & .000 \\
\hline Waktu $\equiv$ & 963.334 & 2 & 481.667 & 67.813 & .000 \\
\hline TitikUkur $\stackrel{*}{W}$ aktu & 34.711 & 6 & 5.785 & .814 & .569 \\
\hline Error & 170.469 & 24 & 7.103 & & \\
\hline Total $\overline{\bar{J}}$ & 200729.188 & 36 & & & \\
\hline Corrected Total & 1515.743 & 35 & & & \\
\hline
\end{tabular}

\begin{tabular}{|c|c|c|c|c|c|}
\hline \multirow{2}{*}{ Titik Ukur } & & \multirow[b]{2}{*}{$\mathrm{N}$} & \multicolumn{3}{|c|}{ Subset } \\
\hline & & & 1 & 2 & 3 \\
\hline \multirow{5}{*}{ 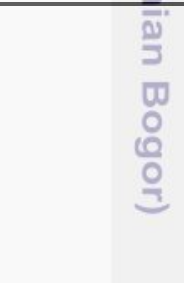 } & $L$ & 9 & 71.01389 & & \\
\hline & $P$ & 9 & 72.45833 & 72.45833 & \\
\hline & $\mathrm{TR}$ & 9 & & 74.87500 & \\
\hline & NP & 9 & & & 79.20833 \\
\hline & Sig. & & .262 & .066 & 1.000 \\
\hline
\end{tabular}

Duncan ${ }^{\mathrm{a}}, \mathrm{b}$

\begin{tabular}{|l|r|r|r|}
\hline Waktu & & \multicolumn{2}{|c|}{ Subset } \\
\cline { 3 - 4 } & $\mathrm{N}$ & 1 & \multicolumn{1}{c|}{2} \\
\hline Siang & 12 & 67.09375 & \\
Sore & 12 & & 77.56250 \\
Pagi & 12 & & 78.51042 \\
Sig. & & 1.000 & .392 \\
\hline
\end{tabular}


Lampiran 9 Hasil Anova dan uji beda kelembaban Hutan Kota BNI

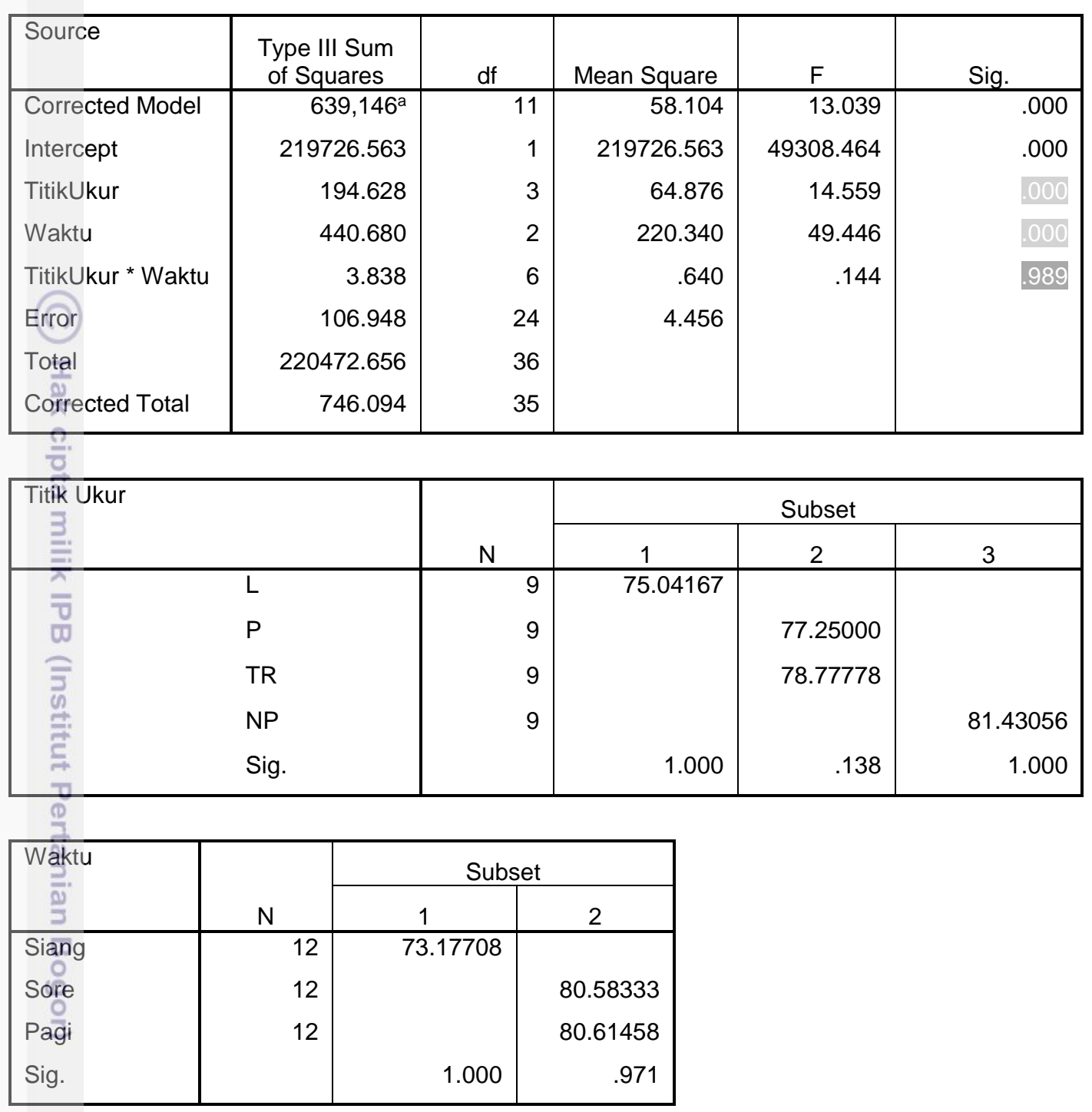

Lampiran 10 Hasil Anova dan uji beda kelembaban ketiga lokasi

\begin{tabular}{|l|r|r|r|r|r|}
\hline Source & \multicolumn{1}{|c|}{$\begin{array}{c}\text { Type III Sum } \\
\text { of Squares }\end{array}$} & df & Mean Square & \multicolumn{1}{c|}{ F } & \multicolumn{1}{c|}{ Sig. } \\
\hline Corrected Model & $931,896^{\mathrm{a}}$ & 11 & 84.718 & 40.868 & .000 \\
Intercept & 206305.210 & 1 & 206305.210 & 99521.806 & .000 \\
TitikUkur & 286.938 & 3 & 95.646 & 46.140 & .000 \\
Waktu & 636.838 & 2 & 318.419 & 153.606 & .000 \\
fitikUkur * Waktu & 8.120 & 6 & 1.353 & .653 & .688 \\
Error & 49.751 & 24 & 2.073 & & \\
Total & 207286.858 & 36 & & & \\
Corrected Total & 981.648 & 35 & & & \\
\hline
\end{tabular}




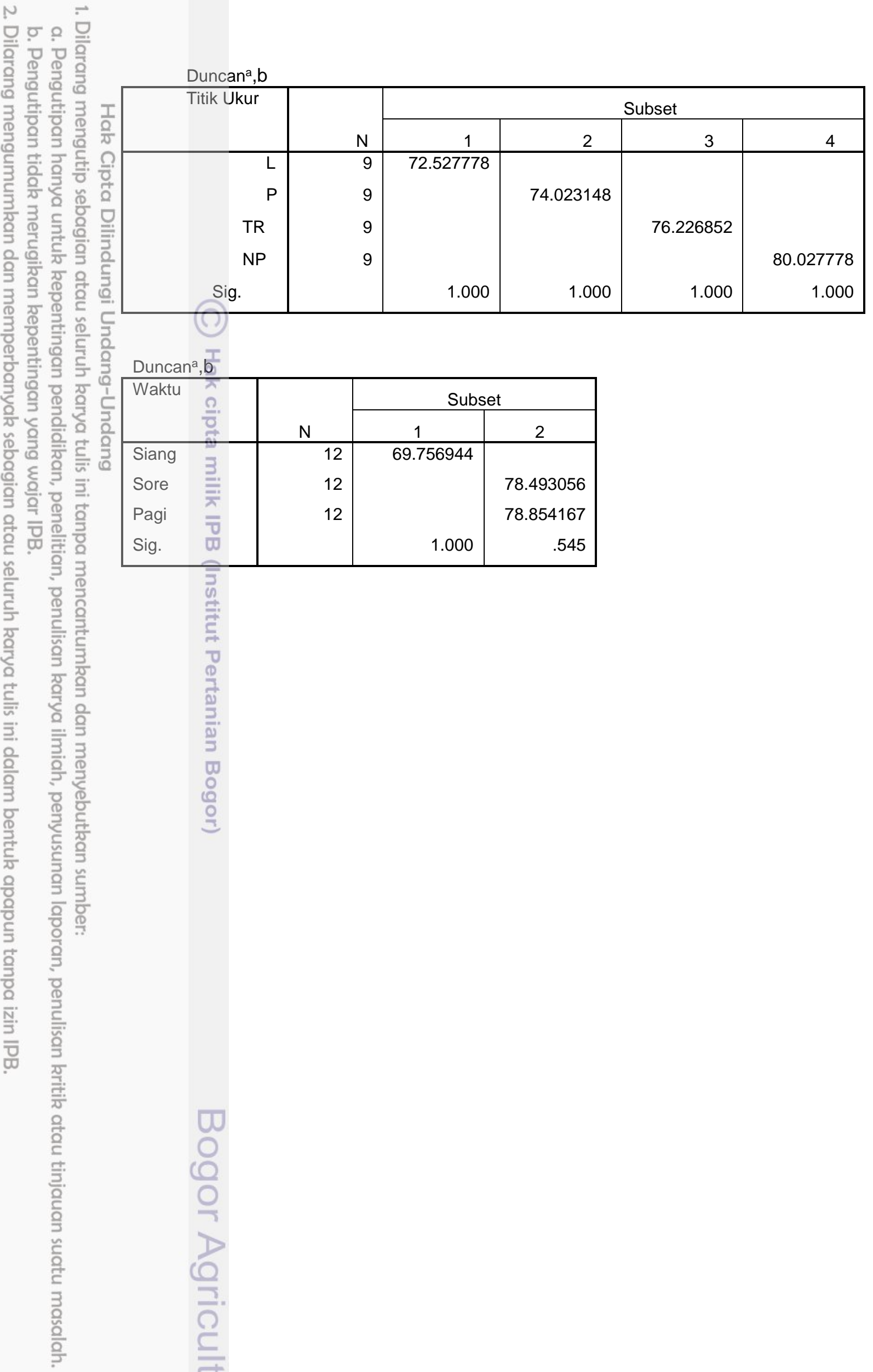




\section{RIWAYAT HIDUP}

Penulis dilahirkan di Bireun, pada 27 Juni 1993, dari pasangan Bapak Azizon dan Ibu Nuraini. Penulis merupakan anak pertama dari dua bersaudara. Penulis mengawali pendidikan formal di MIN Kutablang Lhokseumawe dan lulus pada tahun 2005. Tahun yang sama penulis melanjutkan sekolah di MTsN Lhokseumawe. Penulis lulus dari MTsN pada tahun 2008 dan melanjutkan ke MA Ruhul Islam Anak Bangsa hingga lulus pada tahun 2011. Pada tahun yang sama penulis masuk ke Departemen Arsitektur Lanskap, Fakultas Pertanian, IPB melalui ujian PBSB Kementrian Agama RI atau disebut dengan jalur BUD.

Selama menjalani pendidikan di departemen, Penulis juga aktif dalam beberapa kegiatan kemahasiswaan di tingkat departemen maupun di luar. Penulis aktif sebagai pengurus Himpunan Mahasiswa Arsitektur Lanskap (HIMASKAP) sebagai anggota divisi Eksternal di tahun kepengurusan pertama dan kedua. Penulis menjadi ketua divisi publikasi untuk acara Indonesia Landscape Architecture Students Workshop (ILASW) 2014. Penulis juga aktif dalam peguyuban Mahasiswa Aceh-Bogor, Ikatanan Mahasiswa Tanah Rencong (IMTR). Selain itu penulis juga menjadi anggota dari CSS MoRA (Community of Santri Scholars of Ministry of Religious Affairs).

$\varpi$ Penulis aktif dalam berbagai kepanitiaan baik di acara tingkat mahasiswa, departemen, maupun dekanat. Selama kuliah penulis pernah menjadi asisten praktikum pada mata kuliah Dasar-dasar Arsitektur Lanskap. Adapun Lomba yang perñah diikuti antara lain sayembara Monumen tsunami yang diselenggarakan oleh Lafarge, sayembara kota dalam taman diselenggarakan oleh Arsitektur Universitas Brawijaya, sayembara Taman Mirota Kampus, Sayembara Taman Lapangan Rumput dan Nurseri yang diselenggarakan oleh PT. Bogor Life Science. Selama mengerjakan tugas akhir penulis sempat magang di konsultan Orizen Exotropica. 